Experimental Affinities in Music 



\section{Experimental \\ Affinities \\ in Music}

Edited by Paulo de Assis

Leuven University Press 



\section{Table of Contents}

7

Introduction

Paulo de Assis

15 Chapter One

Explosive Experiments and the Fragility of the Experimental Lydia Goehr

42 Chapter Two

Omnis ars ex experimentis dependeat: "Experiments" in

Fourteenth-Century Musical Thought

Felix Diergarten

64 Chapter Three

"Vieltönigkeit" instead of Microtonality: The Theory and Practice of Sixteenth- and Seventeenth-Century "Microtonal" Music

Martin Kirnbauer

91 Chapter Four

Inscriptions: An Interview with Helmut Lachenmann

105 Chapter Five

Nuance and Innovation in Part I of the " 48 "

Mark Lindley

128 Chapter Six

Tales from Babel: Musical Adventures in the Science of Hearing Edward Wickham

147 Chapter Seven

From Clockwork to Pulsation: Music and Artificial Life in the

Eighteenth Century

Lawrence Kramer

168 Chapter Eight

The Inner Ear: An Interview with Leon Fleisher

177 Chapter Nine

Execution-Interpretation-Performance:

The History of a Terminological Conflict

Hermann Danuser 


\section{Table of Contents}

197 Chapter Ten Monumental Theory

Thomas Christensen

213 Chapter Eleven

Testing Respect(fully): An Interview with Frederic Rzewski Luk Vaes

237 Appendix

239 Notes on Contributors

245 Index 


\title{
Introduction
}

\author{
Paulo de Assis \\ Orpheus Institute, Ghent
}

In the years 2011, 2012, and 2013, the International Orpheus Academy for Music and Theory was constituted under a single rubric: "Artistic Experimentation in Music." This overarching title aimed at disclosing and discussing artistic practices that questioned, challenged, or moved away from dominant or orthodox musical practices. Beyond looking at historically situated examples of "experimental music" (as in the "American Experimental Tradition"), or at experimental practices based on data collection, measurement, and observation (as abundantly done in recent decades in the areas of performance studies and performance science), the aim of this three-year programme was to bring together diverse historical, methodological, and artistic approaches that contribute to a new discourse on experimentation as an "attitude" and not simply as a quantifiable phenomenon. By an experimental "attitude" we mean a willingness to constantly reshift thoughts and practices, to operate new redistributions of the sensible, affording unpredictable reconfigurations of music, art, and society. As the German philosopher Ludger Schwarte (2012, 187, my translation) formulated it, "Aesthetic experimentation starts when the parameters of a given aesthetic praxis are broken, suspended or transcended, in order to work out a particular mode of appearance that reconfigures the field of the visible and of the utterable."

In music, the movement from interpretation to experimentation seems to be particularly arduous. The whole philosophical and psychoanalytical move away from interpretation into more creative and experimental modes-observable already in the 1960 s and 1970 os in works by Michel Foucault (1970, 1972), JeanFrançois Lyotard ([1971] 2002), Félix Guattari (1972, 1979), and Gilles Deleuze and Guattari (1977, and others), but also, even if from a different horizon of thought, in works by Paul Ricœur $(1970,1974)$ - remains largely marginal to most musicians and musicologists. On the other hand, the more recent epistemological debate on experimentation (Ian Hacking 1982) and "experimental systems" (Hans-Jörg Rheinberger 1997), with its fundamental move away from theory-driven practices and with its practice-led approach, is basically unknown to the music community. The breaking, suspending, or transcending of musical practices finds its first obstacle in two all-too-often fetishised qualities: instrumental virtuosity and compositional handcraft. Professional musicians are spontaneously willing to experiment as long as it helps them to achieve "solid" results-that is, to confirm and reiterate the world as it is. Experimentation is usually understood as referring to something still in a phase

DOI http://dx.doi.org/10.11116/9789461661883.choo 
of development, not yet fully accomplished; and from this follow the negative connotations sometimes attributed to it. "Established" composers and performers hesitate about being labelled as "experimental" precisely because they claim to know exactly what their goals are and what they are doing. Scholastic virtuosity and technical accomplishment are so fundamentally inculcated into the making of music that any wish to introduce an experimental attitude is equated with some form of dilettantism-unless one takes experimentation as a synonym for "testing," for repeating experiments to confirm or negate a given hypothesis; that is, unless one reduces artistic practices to pseudo-scientific endeavours with quantitative methods and results. On the other hand, the creative and productive option of embracing an experimental approach while keeping to high standards of technical skill, even virtuosity, is precluded by a still dominant authoritarian concept of musical works and prevailing aesthetic orientations, which, on the basis of disputable ethical concerns, disallows creative reconfigurations of "works," "images of works," or "images of thought."

In his essay "Five Maps of the Experimental World" Bob Gilmore (2014, 23-29) presented five different definitions of the term "experimental music," which should not be equated with "experimentation" in music but which (even though focused in a specific time and geographical space, mostly recent and North American) offer some basic common ground for a broader discussion. Gilmore's five definitions of experimental music are as follows:

(1) The "experimental involves 'the introduction of novel elements into one's music" (Gilmore 2014, 25, quoting Cage [1959] 1961, 73). [John Cage's "soft definition.”]

(2) "An experimental action is 'an action the outcome of which is not foreseen'” (Gilmore 2014, 25, quoting Cage [1959] 1961, 69). [John Cage's "hard definition."]

(3) “Experimental' in music should mean more or less what it does in the sciences" (Gilmore 2014, 26). It implies a method of trial and error applied to composition (composition as research sensu lato). [James Tenney's definition.]

(4) In the 1990 D Daniel Wolf talked about a "post-experimental" phase, meaning that "experimental' refers to a type of music of a particular historical era, essentially, if not quite exclusively, the music of the fifties, sixties, and seventies stemming from Cage's 'hard' definition" (Gilmore 2014, 27). This era implies the operating and maintenance of a complex "experimental scene" that supports itself from within and that includes "the composers themselves, [and] mediating factors compris[ing] a complex network of festivals, foundations, academic institutions, venues, private patrons, performers, publishers, publicists, critics, musicologists, and so on" (ibid.).

(5) “Experimental' is all the interesting new music that isn't avant-garde" (Gilmore 2014, 28). [Michael Nyman's definition.] 
This typology, succinctly but rigorously proposed by Bob Gilmore, situates itself in an "experimental world," which is inspired by the thought of the sociologist Howard S. Becker (see Becker 1982), but crucially remains musically (and not sociologically) oriented. Even if limited to music from the twentieth century, it is a most useful typology both from the viewpoint of historical musicology as well as from the perspective of composers, providing a common framework of reference to diverse practices.

Two complementary questions become inescapable: (1) Was there no experimentation in music before the twentieth century? and (2) Are there no political implications when one advocates and puts into action an "experimental attitude"? Or, formulated differently, Does experimental music (or experimentation in music) remain in a beautifully encapsulated limbo, independent of the world "out there," as suggested by Daniel Wolf's definition, which seems based on an ivory-tower "experimental scene"? At the very end of his essay, Bob Gilmore (2014: 29) refers to the first question, stating, "As regards the work of older composers, I'm of the opinion that some music is inherently, not temporarily, experimental."

What, then, is music that is "inherently experimental"? Reflecting on this question triggers many other related questions: Is there an experimental attitude recognisable in different times, styles, and places? Are there any detectable "experimental affinities" throughout music history? How do new artistic paths emerge through experimental performance or compositional practices? What is the character, function, and potential of experimentation in musical practice? How does experimentation shape artistic identity and expertise? These were the fundamental questions discussed at the International Orpheus Academy for Music and Theory in the years 2011, 2012, and 2013.

The 2011 Academy-Aspects of Artistic Experimentation in Early Music (convenor: Luk Vaes; guest faculty: Mark Lindley, Martin Kirnbauer, Edward Wickham)was centred on artistic experimentation from the Renaissance and Baroque, with particular attention to experimental behaviour in practices of notation and tuning. The 2012 Academy-Interpretation versus Experimentation (convenor: Paulo de Assis; guest faculty: Hermann Danuser, Thomas Christensen, Frederic Rzewski) - challenged the concept of "interpretation" in the field of music performance while investigating musical "experimentation" as an alternative, inclusive path; it also scrutinised the concept of the "work" and diverse notational and editorial practices. In 2013-Experimental Affinities in Music (convenor: Paulo de Assis; guest faculty: Lydia Goehr, Lawrence Kramer, Felix Diergarten, Bob Gilmore) - the Academy focused on experimental approaches through six hundred years of history, from the late Middle Ages to the present day.

The present volume is a collection of reworked, revised, and, in some cases, extended versions of lectures from those academies. Originally, these essays were not conceived for publication in a single-volume collection. However, due to a confluence of circumstances we decided-in line with the already unifying, overarching title of the three academies-to integrate them under the title Experimental Affinities. "Experimental" is to be understood as an adventurous compositional, interpretive, or performative attitude that might cut 
across different ages and styles; "affinities," as a synonym for connectors and connections, convergences, contiguities, or adjacencies in and through diverse approaches (even if dissimilar at first glance). The golden thread throughout the essays is the quest for "inherently experimental" musical practices, pursued variously from interrogating, descriptive, or challenging perspectives, and mainly referring to music composed before the twentieth century (with the exception of the interviews with Frederic Rzewski and Helmut Lachenmann).

Lydia Goehr's essay "Explosive Experiments and the Fragility of the Experimental" makes a sharp distinction between the experiment and the experimental. While the experiment is highly controlled and planned, following strict rules and rigid procedures, the experimental is open-ended, revisable, and fundamentally incomplete. Where the experiment obeys the logic of trial and test, the experimental seeks to break with the authoritative methods and logics behind the works produced in concert halls. Goehr focuses on two historical moments, each represented by a figure: Francis Bacon ("a new beginning at the beginning of modern science") and John Cage ("a new beginning at the end of modern art"). These two figures are articulated through a third one-Theodor Adorno-whose texts on both Bacon and Cage are closely analysed, exposing Adorno's idea that Bacon and Cage promoted the experimental but ended up "walking the more dangerous path of the experiment."

In "Omnis ars ex experimentis dependeat: 'Experiments' in Fourteenth-Century Musical Thought," Felix Diergarten traces the early history of the term experimentum. In a way, Diergarten follows and deepens Lydia Goehr's line of thought, going back-first through Johannes de Muris-to Francis Bacon's earlier namesake Roger Bacon. The essay is focused on the concept of experimentum in Johannes de Muris's Notitia artis musicae (1321), particularly as expounded in its Prologus, showing how Muris pinpoints a fascinating and sometimes paradoxical combination of veneration for authorities and tradition on the one hand and of "experimental," utopian ways of thinking beyond the boundaries of contemporary musical thought on the other.

Martin Kirnbauer presents a detailed panorama of the theory and practice of sixteenth- and seventeenth-century "microtonal" music. Starting with Nicola Vicentino's L'antica musica ridotta alla moderna prattica, Kirnbauer rigorously pursues diverse practical examples of "vieltönige" music from composers such as Ascanio Mayone (Naples, c.1565-1627), Fabio Colonna (Naples, c.1567-1640, actually a scholar), Domenico Mazzocchi (Civita Castellana, 1592-1665), Gioanpietro del Buono (Naples, d. c.1657), Galeazzo Sabbatini (Pesaro, 1597-1662), Giovanni Battista Doni (Florence, 1595-1647), Johann Jacob Froberger (Stuttgart, 1616-67), and Georg Muffat (Megève, 1653-1704). Martin Kirnbauer's lecture at the Academy was accompanied by Johannes Keller's performances of a number of the music examples on a "cimbalo cromatico," accompanied by the soprano Gunhild Lang-Alsvik and the violinist Eva Saladin. ${ }^{1}$

1 These important demonstrations can be heard online at http://www.orpheusinstituut.be/en/experimental-affinities-in-music-repository 
The fourth chapter is an edited transcript of a public conversation with Helmut Lachenmann. Whereas the first three chapters present scholarly essays (moving between philosophy of music and historiography), Lachenmann's interview dives into the creative realms of music composition. Lachenmann starts by elucidating some of his own compositions (including "...Zwei Gefühle...," Scenario, and Pression) and some major stages of his artistic evolution, giving concrete examples of Luigi Nono's and Henri Pousseur's lessons. But the interview includes some other less well-known aspects of Lachenmann's thought: his personal view of specific pieces by Mauricio Kagel (Tactil, Unter Strom), Morton Feldman (The Viola in My Life), and Michael van Biel (Second String Quartet); and his profound understanding of the activity of "writing," of the physical gesture of the hands, with a pen or pencil, on a piece of paper-the moment of "inscription" that gives the chapter its title. In concluding he turns to the impact of John Cage and Luigi Nono ("friends and counterparts") on his own musical thought and practice.

The next three chapters return to scholarly essays, though they vary greatly in style and scope. Mark Lindley's essay is intended to offer a sort of addenda, based on his own findings as described and illustrated at www.sim.spk-berlin. de, to the information in David Ledbetter's book Bach's Well-tempered Clavier: The 48 Preludes and Fugues (2002). With abundant technical detail, Lindley presents Bach's "nuanced tuning," the style of temperament that (in Lindley's view) Bach had in mind for the Well-Tempered Clavier.

Edward Wickham's "Tales from Babel” investigates fundamental questions about the intelligibility of sung texts in medieval and Renaissance music, particularly in polytextual motets. Wickham reports the results of several experiments, tests, and trials involving contrafacta (the use of contemporary texts for medieval music), speech recognition, and hearing psychology based on music by Walter Frye (d. c.1475), Johannes Ockeghem (c.1410-97), and Christopher Fox (b. 1955), among others.

The Cartesian body-mind division is creatively problematised by Lawrence Kramer in a wide-ranging essay that culminates in reflections on musical automata from the eighteenth century. Kramer builds a complex network of arguments that includes references to Voltaire and Hegel, to Freud, Lacan, and Žižek, to Haydn and Beethoven, to Goethe and Herder, to Judith Butler and many more. As his essay unfolds, notions of clockwork and pulsation as used in the eighteenth century become central, helping to better situate the debate between "vitalists" and "mechanists," between conceptions of "interiority" and "expression" in music and beyond. The final section considers Haydn's Sonata in C Minor (Hob. XVI:20, probably composed around 1772), Beethoven's Sonata No. 5, op. 10, no. 1 (composed in 1796), Schubert's Impromptu No. 1 in C Minor, op. 90 (1827), and Lawrence Kramer's own piano quartet Pulsation, composed in 2010-11 and premiered at the 2013 Orpheus Academy. ${ }^{2}$

2 For the video recording of this piece, go to http://www.orpheusinstituut.be/en/experimental-affinitiesin-music-repository 
In the mid-196os, pianist Leon Fleisher's right hand was disabled by what was ultimately diagnosed - but not until 1991-as focal hand dystonia, or repetitive stress syndrome. In response, he concentrated his attentions on teaching, conducting, and mastering the piano repertoire for the left hand. Importantly, this difficult process made him deeply reconsider the nature of music and its powers of expression. The notion of "inner hearing," which Fleisher inherited from his teacher Arthur Schnabel, became central to his activity. In this interview, Fleisher addresses several topics related to music interpretation, to the limits on a performer's freedom, and to diverse methodologies for the learning and practising of music, referring primarily to compositions from the nineteenth century.

Invited for the Orpheus Academy 2012, which had the title of "Interpretation versus Experimentation," Hermann Danuser focused on the first term of the title-on concepts and practices of "interpretation"-presenting a substantial contribution to the history of a complex terminological negotiation between "execution," “interpretation," and "performance." Danuser's careful and detailed attention to the history of concepts (Begriffsgeschichte) is illuminating, as it reveals the deep link between concepts and practices. The terminology we use is never neutral, and it gives notice of our concrete understanding of musical practices. Danuser's final plea in favour of "interpretation" is to be placed in relation to the other concepts discussed previously, namely those of "execution" and "performance," which are not to be directly equated with "experimentation"-a term that, significantly, remains absent in this essay.

Thomas Christensen brings the perspective of a critically engaged music theorist to this volume. Whereas the ontological status of the "regulative work concept" has been closely scrutinised in the last decades-prominently by Lydia Goehr ([1992] 2007) - the ontological status of music theoretical texts has received no comparable challenge among scholars. The major theoretical works of authors such as Boethius, Guido, Muris, Zarlino, Rameau, Kirnberger, Fétis, Riemann, and Schenker remain essentially "untouchable" and could well be interrogated, Christensen asserts, "with a bit more critical acumen and curiosity." In his chapter "Monumental Theory," Thomas Christensen focuses on four examples, from four different ages, challenging the conventional views of (1) Boethius's De institutione musica (sixth century), (2) the early reception of Rameau in Germany (eighteenth century), (3) Hollandrinus, a scarcely known scholar from the second half of the fourteenth century, and (4) partimenti and thoroughbass (eighteenth century), a form of music pedagogy that escapes textual codification. Christensen "simply" reminds us that music theory texts are used by readers, that they are not autonomous objects existing in some idealised world, and that they are social objects whose uses give them a dynamic quality. In this sense, Christensen's essay is a crucial contribution to an urgently necessary destratification of canonical music theory texts.

The last contribution, an interview with Frederic Rzewski, opens up the discourse to infinite horizons and possibilities. In sharp, cutting, and challenging style, Rzewski affirms music as a fundamental space of (and for) freedom. Repulsing all forms of stratification (in music, in particular, but also in thought 


\section{Introduction}

in general) his replies always carry an element of humour or disarming argumentation. Things seem always to be different than one would have thought. And even in his most provocative answers (toward the end of the talk), Rzewski invites the audience to think deeper, more precisely, and more diversely. During the interview (as the transcript shows) the audience several times broke into laughter, spontaneous and loud. And a good laugh — as we know from Nietzsche, but even earlier from Haydn and Beethoven-is a fundamental contribution to opening our minds, to reframing our convictions, to bringing us to imagine other, infinite, possible universes - in a nutshell, to embrace an experimental attitude and to actively look for experimental affinities.

This volume would have been impossible without the help of the Orpheus Institute's collaborators Heike Vermeire, Jonas Tavernier, and Kathleen Snyers during and after the International Orpheus Academy for Music and Theory 2011-13. I thank them for their hard work, engagement, and affability in communicating with the faculty. Regarding the editing process, I am deeply grateful to the Orpheus Institute Series' chief editor, William Brooks, for his thorough revision of the texts and, more particularly, to Edward Crooks, who copy-edited the complete set of essays, raising pertinent questions and suggesting intelligent solutions in a most sophisticated and professional way.

\section{REFERENCES}

Becker, Howard S. 1982. Art Worlds. Berkeley: University of California Press.

Cage, John. (1959) 1961. "History of Experimental Music in the United States." In Silence: Lectures and Writings, 6775. Middletown, CT: Wesleyan University Press. First published 1959 as "Zur Geschichte der experimentellen Musik in den Vereinigten Staaten," translated by Heinz-Klaus Metzger (Darmstädter Beiträge zur Neuen Musik 2: 46-53).

Deleuze, Gilles, and Felix Guattari. 1977. Anti-Oedipus: Capitalism and Schizophrenia. Translated by Robert Hurley, Mark Seem, and Helen R. Lane. New York: Viking Press. First published 1972 as L'AntiEdipe: Capitalisme et schizophrénie (Paris: Editions de Minuit).

Foucault, Michel. 1970. The Order of Things: An Archaeology of the Human Sciences. New York: Pantheon Books. First published 1966 as Les mots et les choses: Une archéologie des sciences humaines (Paris: Gallimard). .1972. The Archaeology of Knowledge.

Translated by A. M. Sheridan Smith. New York: Pantheon Books. First published

1969 as L'Archéologie du savoir (Paris: Gallimard).

Gilmore, Bob. 2014. "Five Maps of the Experimental World.” In Artistic Experimentation in Music: An Anthology, edited by Darla Crispin and Bob Gilmore, 23-29. Orpheus Institute Series. Leuven: Leuven University Press.

Goehr, Lydia. (1992) 2007. The Imaginary Museum of Musical Works: An Essay in the Philosophy of Music. Rev. ed. Oxford: Oxford University Press. 1st ed. published 1992 (Oxford: Oxford University Press).

Guattari, Félix. 1972. Psychanalyse et transversalité: Essais d'analyse institutionnelle. Paris: Maspero. Translated by Ames Hodges as Psychoanalysis and Transversality: Texts and Interviews, 1955-1971 (Los Angeles: Semiotexte(e); Cambridge, MA: MIT Press, 2015).

_- - 1979. L'inconscient machinique: Essais de schizo-analyse. Paris: Recherches. Translated by Taylor Adkins as The Machinic Unconscious: Essays in Schizoanalysis (Los Angeles: Semiotext(e), 2011). 


\section{Paulo de Assis}

Hacking, Ian. 1982. "Experimentation and Scientific Realism.” Philosophical Topics 13 (1): 71-87.

Ledbetter, David. 2002. Bach's Well-tempered Clavier: The 48 Preludes and Fugues. New Haven, CT: Yale University Press.

Lyotard, Jean-François. (1971) 2002. Discours, Figure. 5th ed. Paris: Klincksieck. 1st ed. published 1971 (Paris: Klincksieck). Translated by Antony Hudek and Mary Lydon as Discourse, Figure (Minneapolis: University of Minnesota Press, 2011). Rheinberger, Hans-Jörg. 1997. Toward a History of Epistemic Things: Synthesizing Proteins in the Test Tube. Stanford, CA: Stanford University Press.

Ricœur, Paul. 1970. Freud and Philosophy: An Essay on Interpretation. Translated by Denis Savage. New Haven, CT: Yale University Press. First published 1965 as De l'interprétation: Essai sur Freud (Paris: Editions du Seuil).

. 1974. The Conflict of Interpretations: Essays in Hermeneutics. Edited by Don Ihde. Translated by Willis Domingo, Kathleen McLaughlin, Robert Sweeney, Peter McCormick, Denis Savage, and Charles Freilich. Evanston, IL: Northwestern University Press. First published 1969 as Le conflit des interprétations: Essais d'herméneutique (Paris: Editions du Seuil).

Schwarte, Ludger. 2012. "Experimentelle Ästhetik: Arbeit an den Grenzen des Sinns." Zeitschrift für Ästhetik und Allgemeine Kunstwissenschaft 57 (2): 185-95. 


\title{
Explosive Experiments and the Fragility of the Experimental ${ }^{*}$
}

\author{
Lydia Goehr \\ Columbia University, New York
}

\begin{abstract}
Distance is not a safety-zone but a field of tension. It is manifested not in relaxing the claim of ideas to truth, but in delicacy and fragility of thinking.

-Adorno, Minima Moralia ([1974] 1978, 127)
\end{abstract}

The English "to explode" has at least one origin in the theatre, in the term "to applaud"-ex-plaudere - where the idea is not necessarily to keep the actors on the stage but to drive them away by clapping, hissing, or booing, as though an audience were imitating the sound of a failed experiment or reacting to something that had just blown up in their face. When experiments succeed, they typically result not in explosions, unless they aim for such, but, instead, in the silent concord of the elements. From this, the thought arises that perhaps one should respond in the theatres of art and science with quiet murmurs of awe and not with the loud bravos and eurekas to which we have become accustomed.

Adorno writes about applause differently, beginning with the assumption that applause means praise, though what he thinks is being praised is not what we would expect. Writing about the "Natural History of the Theatre," he claims that applause "is the last vestige of objective communication between music and listener" (Adorno 1992, 65). When listening to music under advanced conditions of administered society, the now distracted listeners fail to listen even as the music goes on. When the music stops, they applaud anyway. Adorno sees in this behaviour something approaching an ancient ritual sacrifice as when our ancestors applauded the slaughter of animals. Applause, he argues, was always ceremonial or ritualistic and remains so in our modern institutions.

\footnotetext{
DOI http://dx.doi.org/10.11116/9789461661883.cho1

* First published as "Explosive Experimente und die Fragilität des Experimentelle: Adorno, Bacon und Cage" in Spektakuläre Experimente: Praktiken des Evidenzproduktion im 17. Jahrhundert, edited by Helmar Schramm, Ludger Schwarte, and Jan Lazardzig, 477-506 (Berlin: de Gruyter, 2006); republished in: Lydia Goehr, Elective Affinities: Musical Essays on the History of Aesthetic Theory, 108-35 (New York: Columbia University Press, 2008). Reprinted here by permission of the author and the publishers (de Gruyter and Columbia University Press).
} 
When we applaud at a concert, it is less a liking of the music that we express than our appreciation of the ritual. However, the pleasure we find in the ritual is false and displaced, emanating as it does only from a borrowed remembrance of something once done when humanity bore a nonalienated connection to the world.

\section{THE BACKGROUND}

This chapter is not directly about applause but about the surrounding history of modernity in which both scientists and artists articulate the terms of meaning or experience by confronting the breach they take to have emerged between human beings and nature. It concerns those who, through experimental science or experimental art, claim that nature can still exist as a living presence within human experience. I focus on two distinct historical moments. Somewhat rhetorically put, the first moment marks a new beginning at the beginning of modern science, and the second, a new beginning at the end of modern art. Each moment is represented by a single figure: the first, by one of the fathers of experimental science, Francis Bacon, though being the father of experimental science is usually the definite description awarded to him; and the second, by one of the fathers of experimental music, John Cage, though to speak here of the father is to give authority to someone who lived his life in overt refusal of such.

Despite obvious differences, Bacon and Cage assume in their modes of experimentation a shared attitude toward nature, characterised more by nobility and respect than by violent intervention. Neither seeks to torture or manipulate nature through technological means. Both look for a way to let nature's mystery and secrets reveal themselves to the inquiring mind. For both, experimentalism has an emergent character; they want to know what can emerge out of nature to the observing eye or listening ear. Both of them argue for preserving an element of magic or chance in their languages of, respectively, science and art. Both, finally, ponder the nature of their inquiry. Bacon was an essayist who wrote in aphorisms to separate himself from traditional writers of method. Cage was a composer and writer who rejected anything approximating an authoritative grammar.

To bring the two figures together is not altogether original. Adorno did this before me, though in not so shared a philosophical breath. He brings them together in his overarching description of the dialectic of enlightenment and in far more devastating terms than mine. Despite their pleas for genuinely open inquiry, Adorno sees in both the tendency toward an absolute domination of nature. With Horkheimer, he regards Bacon's early "hounding” after absolute knowledge as having encouraged thinkers along a path that ended up in Cagelike attempts to restore life to a nature that humanity had already put to death. Horkheimer and Adorno write in their opening lines: 
Enlightenment, understood in the widest sense as the advance of thought, has always aimed at liberating human beings from fear and installing them as masters. Yet the wholly enlightened earth is radiant with triumphant calamity. Enlightenment's program was the disenchantment of the world. It wanted to dispel myths, to overthrow fantasy with knowledge. Bacon, "the father of experimental philosophy," brought these motifs together. (Horkheimer and Adorno 2002, 1; [1947] $1981,19)^{1}$

Although Adorno describes enlightenment's path in the bleakest of terms, he hopes that the world might one day be different from how it currently appears. With Bacon and Cage, he seeks the aesthetic, scientific, and philosophical seeds of a free or nonadministered mode of experience (Erfahrung). Though he finds error in the path that leads from the scientific Bacon to the artistic Cage, he shares their aim to find in experience the dimension of the genuinely experimental. The connection or even (as in French) the identity drawn between the terms "experience" and "experimental" is anything but accidental. Adorno shows that though he takes Bacon to task as the father of experimental science, he is willing to continue Bacon's essayistic or aphoristic approach toward philosophy: "The English empiricists ... called their philosophical writings essays, because the power of a freshly disclosed reality, upon which their thinking struck, continuously forced upon them the risk [or trial] of experimentation [das Wagnis des Versuchs]" (Adorno 1977, 132 [transl. amended]; 1997b, 1:343). Or:

Since Bacon-himself as essayist-empiricism has been as much a "method" as rationalism. In the realm of thought it is virtually the essay alone that has successfully raised doubts about the absolute privilege of method. The essay allows for the consciousness of nonidentity, without expressing it directly; it is radical in its non-radicalism, in refraining from any reduction to a principle, in its accentuation of the partial against the total, in its fragmentary character. (Adorno 1991-92, 1:9; $\left[195^{8-74}\right]$ 1974, 17)

With these words, Adorno mirrors Bacon's own:

Another diversity of Method, whereof the consequence is great, is the delivery of knowledge in Aphorisms, or in Methods; wherein we may observe that it hath been too much taken into custom, out of a few axioms or observations upon any subject, to make a solemn and formal art, filling it with some discourses, and illustrating it with examples, and digesting it into a sensible Method. But the writing in Aphorisms hath many excellent virtues, whereto the writing in Method doth not approach.... Aphorisms, representing a knowledge broken, ... . invite men to inquire further; whereas methods, carrying the show of a total, ... secure men, as if they were at [their] furthest. (Bacon [1605] 2001, 145-46)

1 In their own note, the authors refer to the twelfth letter of Voltaire's Lettres philosophiques for the source of their reference to Bacon as "the father of experimental philosophy." Thereafter, in their account, they imitate both the tone and language of this letter. Where two citations are provided for the same quotation, the first refers to the quoted translation, the second to the foreign-language original. 
THE TOPIC

In this essay, I make explicit the concept of the experimental by tracing its course in an enlightenment history that is well described as having become dominated by the contrary concept of the experiment. Though Bacon and Cage promote the experimental, they end up, Adorno maintains, walking the more dangerous path of the experiment. In dialectical terms, what the experimental shows about the experiment is the latter's tendency, despite itself, to control and thus eventually to kill nature through tortures performed in enlightenment laboratories of science and art.

Whether and with what deliberation Adorno misreads the work of Bacon or of Cage is only part of my concern. I am more interested in showing what is at stake in distinguishing the experimental from the experiment. However, given the first remark, one should remember that Adorno is by no means alone-and independently of his collaboration with Horkheimer-in interpreting Bacon as having started experimental science off on a route that led to humanity's most deadly experiment on nature. This was an experiment in which the experimentalists or philosophers sought in their rational pursuit of absolute knowledge to overcome the respectful distance that their predecessors kept from the objects of their inquiry. Goethe and Schiller also severely criticised the Baconian path, as later did Nietzsche, Heidegger, Popper, Marcuse, and, finally, Cassirer, from whom, in fact, most contemporary critics have taken their cue.

Cassirer began his criticism by seeing in Bacon's rules of experimental operation a radical demarcation of "the modern from the medieval age" (Cassirer 1953, 46). With these rules, Bacon renders knowledge indistinguishable from power. All this Bacon admitted himself. However, instead of regarding nature as a given, something to be speculated about at a distance or observed through sensory experience, Bacon, so Cassirer objected, brings nature into conformity with the human-made experiment. He introduces into scientific inquiry an essentially juridical, even inquisitorial, character, leading Cassirer finally to find in the father of experimental science also the first torturer of nature:

Bacon sits as a judge over reality questioning it as one examines the accused. Not infrequently he says that one must resort to force to obtain the answer desired, that nature must be "put to the rack." This procedure is not simply observational but strictly inquisitorial. The witnesses are ... brought face to face; the negative instances confront the affirmative ones, just as the witnesses for the defence confront those for the prosecution. After all the available bits of evidence have been gathered together and evaluated, then it is a matter of obtaining the confession which finally decides the issue. But such a confession is not obtainable without resorting to coercive measures. "For like [and here Cassirer is quoting Bacon] as a man's disposition is never well known or proved till he be crossed ... so nature exhibits herself more clearly under the trials and vexations of art than when left to herself." This is obviously not the language of the contemplative thinker who is confident of the harmony between the human mind and reality and entrusts himself lovingly to the pure revelations of nature. (Cassirer 1953, 48-49) 
I return to this reading of Bacon below, but note immediately that it was not actually Bacon who wrote of "putting nature to the rack," as traditionally claimed, but Leibniz in 1696 (see Pesic 1999). ${ }^{2}$ Still, Bacon's critics have always ranged from one extreme to the other: from those who regard him as the instigator of the most violent experiment to those who see in his work a profoundly aesthetic or experimental core, and the latter despite the inquisitorial nature of his language. It is my impression that the particular debate that has so shaped Bacon's reception has always been paradigmatic of the larger debate concerning the concepts of the experiment and experimental—so to this distinction I now turn.

\section{THE DISTINCTION}

Over the course of their undeniably overlapping histories, the two concepts have come to track increasingly opposed tendencies toward violence and non-violence, loud noises and quiet sounds. Nevertheless, it has not always been clear which concept has embodied which tendencies at which particular time. Not everything is bad about the experiment and not everything is good about the experimental, although the need to say this already suggests something about the different connotations of the terms. Over time, they have become competitor concepts. One sees this straightaway if we look at how the concepts have guided the development and procedures in science and art, as well as in society, religion, and politics.

It surprises me that in not one of these areas has the distinction been explicitly conceived, although it has broadly been assumed. One might claim that the distinction has always been so self-evident that it requires no explicit acknowledgment. But I do not think this is correct. Or one might claim that the movement between the two concepts over the entire range of their extensive use has been sufficiently smooth that it has not been necessary to draw a hard distinction between them. To be sure, one may speak of experiments in terms of the experimental techniques involved or the experimental data produced, just as one may speak about an experimental procedure as involving experiments with various kinds of materials, tools, or instruments. Hence, one may obviously move between the terms without semantic loss or gain. Still, it not only makes sense to say, but sometimes it is most revealing to claim, first, of a particular experiment, that it has nothing of the character of the experimental, and, second, of the experimental, that it has nothing of the character of the experiment. This secures my thought that between the two concepts there has emerged at least a strong difference of connotation.

To render the distinction explicit is to expose some of the most antagonistic tendencies of modernity. The difference has grown the more it has become implicated in occasions of critique, in cases where, as with Bacon, Adorno, and Cage, the purpose is to develop new ways of conceiving nature's relation to

2 Pesic (1999, 82n3) cites Gross's Rhetoric of Science (1990, 87n6, 212): "Although the sentiment is Baconian, the phrase is from Leibniz." See also Mathews (1996); Bossy (1996); Merchant (2006). 
humanity or to art. In this content, the terms "nature" and "art" are used both to distinguish the sadly separated spheres and to separate thoughts about the natural, spontaneous, and free from thoughts about the artificial, intentional, and human-made. If the history of the experimental and the experiment is a story of modernity, it is because of what it contributes to our understanding of our relation to both nature and art. With this, the focus quickly turns to matters of life and death - equally of humanity, nature, and art-and with the focus so turned, the term "experiment" assumes the more negative connotation.

Consider the various domains in which the general concepts of the experiment and the experimental have acquired a particularly significant use without yet attending to their difference. There is obviously the history of experiments in the laboratories of experimental science stemming back to the seventeenth century. There is also the complex history of political and religious experiments, the oft-named "wonderful experiments" associated with the developments of socialism, communism, fascism, and democracy. To speak of political experiments was particularly common after 1900 . However, as early as 1845, Marx (quoting Bruno Bauer) described the French Revolution as "an experiment," a bourgeois one that by belonging more to the eighteenth than to the nineteenth century was dialectically out of date (Marx and Engels 1975-2004, 118-19). With political experiments came all the social experiments: Jeremy Bentham's so-described "humane experiments in penal reform," Friedrich Engels's industrial experiments, and John Dewey's later pragmatist experiments in education. Then there were the philosophers' thought experiments, with John Stuart Mill and Ernst Mach encouraging the exercise along an increasingly positivistic path. Then, finally, there is the history of modern art in which it has long been assumed that the more experimental the technique, technology, or artistic principle, the more avant-garde the art.

In none of these areas have the concepts of the experiment or the experimental been applied neutrally. From modernity's beginning, they have both been caught up, for better and worse, in value-laden theories of progress. Some theorists have claimed that all new art is necessarily experimental, where what "the new" and "the experimental" immediately suggest is the idea of trying things out that haven't been tried before. With this sense of trial has come the admission of the possibility of failure: to be experimental is to take a risk. And with this has come a recognition of the essential ambiguities or indeterminacies in our ways of knowing. Other theorists have contrarily stressed more the experiment than the experimental, seeing in the experiment a sober way to develop a risk-free or secure path to advance knowledge: to get things right or to reach certainty by incrementally differentiated means and finely controlled testing.

Recall a moment in a movement in art's history that will nevertheless quickly return us to science. The movement was Italian Futurism. In part of their famed manifesto (written by Luigi Russolo in 1913), the Futurists celebrated their noisy experiments by proclaiming with loudspeakers a new "art of noises" explicitly to oppose the purported silence of an "ancient life," and "nature" that purportedly once existed in happy accord. "If we overlook such exceptional movements as earthquakes, hurricanes, storms, and avalanches," 
they wrote, nature "is silent." Only now has noise been born to triumph over our once quiet sensibilities. For many centuries, life went by in the most muted and musical of tones; now, however, the modern world is all "Rumbles, Roars, and Explosions" (Apollonio [1973] 2001, 74-88). ${ }^{3}$

For the Futurists, though not only for them, the new noises were brought into the traditional arts of both ear and eye. Photography and film-the new forms of visual art-were forced to acknowledge or even to rejoice in their noise. Consider, at least in English since the 1890s, the prevalence of the violent language of "the shoot" or of "taking a shot" to describe how a camera captures images. Maybe it was only the clicking mechanism and less any actual bang that generated the latter description-although perhaps not if one recalls the use of the camera-cum-gun in Kurt Weill's 1927 one-act opera Der Zar lässt sich photographieren. Whatever the reason, noise was certainly the issue when early filmmakers realised that they did not know how to prevent the noise of the droning camera in the transmission of silent images and decided to introduce music as a mask, only then to discover that a droning phonograph, when such was used, worsened the situation.

Another motivation for introducing music into film regarded its potential to complete the new art. Henceforth, film, it was claimed, could accommodate all sensorial dimensions in a single construction and, with this, offer a total (synthesising) and a totalising (all-absorbing) experience. Moving beyond the grand Wagnerian synthesis, film could create the absolute illusion, indeed the perfect copy of modern life-although to use the word "copy" was no longer deemed suitable for a medium claiming to surpass all differences between the fictional and the real. Whereas, formerly, in the mimetically imperfect and divided arts, the illusion of the real was protected by a distancing disbelief that sustained the illusion as an illusion, film claimed to overcome the gap. Some theorists celebrated what they took to be the new control and mastery of the real. Others did not and bemoaned the loss of an old, quiet, and noble realism as it was increasingly replaced by a new, noisy, and overtly authoritative idealism.

Much of what was written about the end of modernity was written also about its beginnings: the moment, for example, when experimenters in science began to see nature no longer as something standing at a safe distance from their observing eyes but as something in to which they could pierce their experimental knives. Even in this period, so it was written at the time, the scientists separated themselves from the magicians. In the 1930s, Benjamin drew on just these terms to describe the emerging analogy between the filmmaker and the scientist in the modern age of technological reproducibility. In the age of ritual or cultic art, he argued, artists acted like noble magicians, creating illusions of the natural world without cutting it up. However, by the end of Benjamin's age, artists had become fully what scientists already were-experimenters who sought not to leave nature as it is but to instrumentalise it in the name of progress. Most critics held Francis Bacon responsible for initiating the entire surgical movement.

3 For Futurism's reception in music, see Payton (1976). 
A similar discourse on science and art was offered again in 1963 by Edgar Wind when he declared in his marvellous book on art and anarchy that art had become "experimental," to which he then added:

\begin{abstract}
It is significant that this word "experiment," which belongs to the laboratory of the scientist, has been transferred to the artist's studio. It is not a casual metaphor: for although artists today understand far less of science than they did in the sixteenth or seventeenth century, their imaginations seem haunted by a desire to mimic scientific procedures; often they seem to act in their studios as if they were in a laboratory, performing a series of controlled experiments in the hope of arriving at a valid scientific solution. And when these astringent exercises are exhibited, they reduce the spectator to an observer who watches the artist's latest excursion with interest, but without vital participation. (Wind [1963] 1985, 20-21)
\end{abstract}

In this passage, Wind moved automatically from using the term "experimental" to using the term "experiment," with the result that he transformed what might have begun as a positive claim about art into a negative one. Here, at least, he did not acknowledge the possibility that art might have become experimental without its having fallen into the controlling traps of the experiment.

Over time, the idea of the experiment (be it in science, politics, or art) has increasingly exuded the aura of complete control over what it seeks to investigate. This prompted a colleague of mine recently to ask whether when one speaks of political experiments one immediately associates the idea with tyranny. Indeed, the German noun das Experiment has assumed a connotation far more extreme than when one speaks of an experiment in politics or, even more, of the experimentation or experimentalism involved in this or that political system. To try things out in a democratic process sounds a lot better than imposing democracy as a pre-packaged system on a country, as though the outcome were decided in advance. Analogously, when Goethe offered his theory of colours, he proposed an experimental method that was quite different from the analytical attitude of Newton's method, just because Newton as "Inquisitor" tortured nature to extract the confession of what he'd "already decided" (Goethe [1810] 1958, 45; cf. Schöne 1987, 64-66). Goethe was drawing on two already-entrenched ideas: first, that of torturing nature to extract a confession; second, given the experimental methods of his time, that outcomes are decided in advance of testing.

Put at the extreme, reference to the experiment suggests a type of control whereby one attempts to subsume in advance that which one seeks to explain; whereby a method of testing is devised in which the outcome is predicted at the outset; whereby the testing is a matter merely of confirming or falsifying the hypothesis under strict conceptual conditions and optimal conditions of observation; whereby maximal control of material, sample groups, questions, and observation procedures is encouraged, given advanced statistical and measuring methods that control patterns of similarity, uniformity, and variation; and whereby, finally, the criteria of correctness or success are clarified but in such a way that what counts as a failure of the experiment is absorbed as part of its truth content. In short, in an experiment, the planning happens in 
advance, clear objectives are laid out, and optimal conditions are sought; where errors occur, they are conveniently theorised and controlled.

At this extreme, consider Peter Cohen's 1989 documentary The Architecture of Doom, which traces the aestheticising ideology of Nazi Germany. Just when Hitler knew his war was lost, we are told, he absorbed the defeat into a world-historical myth repetition, according to which, regarding the Roman Empire first and Nazi Germany later, empires rise and fall several times before final victory is secured. The defeat of Nazi Germany was, therefore, just a stage along the way in "the great experiment." Hence, even when experiments go wrong, the failure is absorbed as already predicted. In the worst or most dishonest cases, the undesired explosion does not force a change of method or theory but only leads experimenters ever more dogmatically to assert the truth of their hypotheses. One might describe this dogmatism further, in terms of an overarching commitment to a most dangerous version of historicism.

At the other end of the spectrum, the concept of the experimental exudes the aura of open-endedness, revisability, and incompleteness-a "wait and see" attitude. It recalls Montaigne's term "essai," a term used also by Bacon and Leibniz and by German writers (including Adorno) who tided their texts with "Versuch zur" or "Entwurf zur," expressions that became prominent in the eighteenth century to convey the dynamic sense of an incomplete journey. (Hence, also, the associated preference for experience understood as Erfahrung [from fahren], in contrast to the more complete or self-contained idea of an Erlebnis.) Most experimentalists associated their trials made along the ongoing investigative path not with courts of torture run according to strict inquisitional law but with theatres in which evidence could be weighed on quieter and more balanced scales. When Goethe described his colours as arranged in a circle, he contrasted his image to Newton's "analytical” image. Instead of looking at colours diffracted or broken (gebrochen) through a prism, he preferred to view a spectrum for the organic harmony it revealed between nature and ourselves as knowing subjects.

Bacon also wrote about this sort of organic harmony, but apparently he did not convince. What he described as a harmonious relationship was seen by others as little better than a patriarchal marriage or, even more cynically, as a "happy match," in which, in Horkheimer and Adorno's words, "the mind, conquering superstition, [rules] over disenchanted nature" (2002, 1-2; [1947] 1981, 20). Goethe also saw in Bacon's experiments the suggestion if not of disenchantment then of sacrifice: the sacrifice of nature for the sake of human progress. Thinking about the experiments of Robert Hooke, Goethe referred to Bacon's “experimentum crucis," where the term "crucis” suggested to him not only a crossroad or crucial experiment but also a crucifix, as when a person's vessels in being nailed to a cross are, to use Bacon's own language, "fractured" (quoted in Schöne 1987, 64-66).

In Goethe's age, the worry over the dangers of the analytical experimentalist became ever more severe. Stressed by the demands of scientific or philosophical writing in opposition to those of poetic writing, Schiller warned in his very first letter on the aesthetic education of humanity of the paradox into which so 
many writers of his day were being thrown. His terms are again reminiscent of that for which Baconian science had already come to stand:

\begin{abstract}
Like the analytical chemist [der Scheidekünstler], the philosopher can only discover how things are combined by analysing them, [and can] only lay bare the workings of spontaneous Nature by subjecting them to the torment [Marter] of his own techniques [Kunst]. In order to lay hold of the fleeting phenomenon, he must first bind it in the fetters of rule, tear its fair body to pieces by reducing it to concepts, and preserve its living spirit in a sorry skeleton of words. Is it any wonder that natural feeling cannot find itself again in such an image, or that in the account of the analytical thinker truth should appear as paradox? (Schiller 1967, 4-5)
\end{abstract}

Schiller continued the thought, however, by noting the necessity for at least some kind of violence when it comes to the making of art, when, say, artists are obliged to break down the materials for the sake of producing new forms. Schiller shared this attitude with both Bacon and Adorno, implying that not all sorts of violence are to be dismissed. Goethe recognised the point, too, though he was prone to criticise his friend for his tendency to use harsh language and for the sometimes aggressive expression of his thought.

\title{
CAGE
}

If Bacon's work initiated a deep quarrel between opposing tendencies at the beginning of modern science, John Cage's work did the same at the end of modern art, though admittedly not to the same degree. Even so, in 1939 and after, it was the dogmatism of the experiment that Cage determined to relinquish when he described his preferred form of experimental music. In his book pertinently called Silence (1961), he rejected much of the loudness of the modern Western world. At first he expressed doubts about using the term "experimental," thinking it might lead to a confusion of his project with other avantgarde projects around him, though later he said he found comfort in the term, especially when he realised how far (now in my terms) his experimental music would avoid assuming the controlling character of the experiment (Cage 1961,

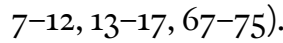

Cage separated his idea of experimental music from the high modernist approaches to composition such as those developed by Milton Babbitt and Elliott Carter. This was an approach, Cage (ibid., 72) quipped, that by adding "a new wing" to the already established academy, opens "no doors to the world outside." Then he separated himself from those composers who, in his judgement, merely introduce popular or jazz elements without effect into their ever more eclectic compositional forms. Finally, he distinguished himself from those engaging in pervasive experimentation on new materials and instruments, even if, evidently, he sometimes enjoyed doing the same.

What made Cage's preferred conception of experimental music distinctive was the purpose it expressed to break with the sort of authoritative works produced in concert halls, where works had allegedly closed down the experience of performers and listeners, given their tendency to function like experiments 
with predetermined outcomes. Like Adorno, Cage believed that we could not overestimate the deadening impact the traditional work concept had had on the listening experience. When we purchase a ticket for a work-based concert, we know in advance what we are going to hear. Live concerts have become increasingly like living-room listening, where recordings are approached with the expectation that the ever-the-same is heard each time, where the risk or experimentalism of the experience has been suppressed in favour of the already known. If the criticism of the live bourgeois concert was being exaggerated, it was so to call attention to how much authority the work concept had assumed in the performance practice of classical music. Music as a performance practice had given itself over to the highly controlled assembly production of products.

Cage determined to open the work concept up to the paradoxical degree that it would relinquish all control or, more carefully, all traditional control over a performance event that continued nevertheless to occur in the work's name. He described the change in terms of indeterminacy and openness: to free the work was to open one's mind, which significantly meant releasing the mind and musical production from inherited dogma. ${ }^{4} \mathrm{He}$ wrote enthusiastically with new words and designs on his pages about the events, happenings, or occasions of experimental music in which the genuinely creative activity would be done by performers and listeners in a new theatre of happy and open collaboration. Insofar as composers and conductors would continue to contribute to the event, they would do so in "contiguous" or participatory roles also as performers and listeners. "The conductor of an orchestra," Cage (1961, 72) quipped, "is no longer a policeman." Or one might say in Cagean spirit: his experimental works would be occasions for rather than of experience (Erfahrungen rather than Erlebnisse). In occasions of experience, one would always know what would happen in advance of the actual experiencing of the experience, rendering the actual experience unnecessary. In Cage's happenings, by contrast, one would genuinely not know, musically at least, for what one was buying a ticket; and that surely was liberating, especially because it would make the actual having of the experience once again necessary.

The critical element of Cage's own experimentalism was directed against institution and method and redirected toward the revival of the emergent musical experience. He used the term "experimental" to capture "an act" of which "the outcome" could not be judged for its success or failure before its occurrence. "What is the nature of an experimental action?" he asked. "It is simply an action the outcome of which is not foreseen.... for nothing one does gives rise to anything that is preconceived" (Cage 1961, 69). But then, even after the occurrence, still nothing can be judged, insofar as the performance is no longer a repetition or an exemplification of an already existing thing. There is nothing, therefore, in a performance that definitively "proves" anything about the work as such. If "work" language remains at all, then it does under the condition that one performance "of a work" will preferably or even necessarily sound quite different from any other. "The word 'experimental' is apt," Cage

4 For more on the open work in Cage, see Perloff (2002). 
explained, "providing it is understood not as descriptive of an act to be later judged in terms of success and failure" (ibid., 13). It isn't an act that "move[s] in terms of approximations and errors ... for no mental images of what would happen were set up beforehand; it sees things directly as they are" (ibid., 15).

To argue against the bourgeois work concept was for Cage to argue against the human, or at least the traditional, control of sound. Music had been overly constrained by a human grammar or by a particularly high Western or European set of conventions. Too much had been excluded from this musical domain, and what was admitted had been overly exploited. To liberate sound was thus to bring everything into this musical domain or, better, to take everything to the musical outside, to overcome the artificial chasm between art and life or between music and natural sound. To "give up" on traditional music is to turn psychologically to "the world of nature," Cage $(1961,8)$ wrote, "where, gradually or suddenly, one sees that humanity and nature, not separate, are in this world together; that nothing [is] lost when everything [is] given away [of our determinations]. In fact, everything is gained. In musical terms, any sounds may occur in any combination and in any continuity." Cage accordingly described the need to let sounds be themselves, to allow something unknown-the element of chance and surprise- to occur in the listeners' experiences. This would happen, he insisted, only when "the measuring mind" stops believing that one day it will have succeeded in measuring nature (ibid., 10).

It is important that Cage was describing a psychological turn, suggesting a profound change of perceiving the world around us. When he made it look like an ontological turn, which he sometimes did, it assumed a more contradictory or deceptive character. For, in an ontological turn, all that remained of the distinction between music and sound was an identity. It was the ontological turn or reduction to which Adorno most objected and with which he ungenerously associated Cage's view. The ontological turn that sought a gapless identity between music and natural sound risked falsely dehumanising by overidealising both sides.

Cage focused on the re-creation of musical experience that would occur under his guidance in a control-free, non-intentional, and naturalised environment. He declared his music purposeless, all-inclusive, and open to creating a new awareness of the surrounding auditory world. We are technically equipped, he told us, to transform our contemporary awareness of nature's manner of operation into art. To where or what would this new sort of listening to nature's operation lead us? To the participation of our eyes and ears, he answered, in a theatre of becoming based on the new idea of a naturalised or environmental theatricality. 5

Having shed his vision of a worn-out European legacy, he adopted what he considered a truly American form of experimentalism, if only, he added,

5 In recent philosophy of science, there has been a marked effort to identify the theatrical qualities of experimentalism in early scientific experiments. Much of this effort has involved rereading the history of science back to Bacon to determine what was lost in later, overly positivistic interpretations of that history. See Steven Shapin's exemplary article "The House of Experiment in Seventeenth-Century England" ([1988] 1999). 
America would actually support it! "America has an intellectual climate suitable for radical experimentation. We are, as Gertrude Stein says, the oldest country of the twentieth century. And I like to add: in our air way of knowing nowness." When once Cage heard someone tell him that "it must be very difficult for you in America to write music, for you are so far away from the centers of tradition," he responded to the contrary: "It must be very difficult for you in Europe to write music, for you are so close to the centers of tradition" (Cage 1961, 73). The contrast between America and Europe was more ideological than geographical: many Europeans were also contemporaneously trying to sever connections to a certain past.

\section{BACON}

Cage went further than Bacon in his idea of experimentalism, and not just because his argument was offered several centuries later. Nevertheless, the question remains: How far did they track the same or different paths? To pursue this question, I go back to Bacon before going forward again to Cage. In an obvious way, it looks as though Bacon long ago denied explicitly what Cage promoted - that our experience ought to extend "beyond the actual experiment" (Bacon 1857-74a, 70). Bacon (ibid.) insisted that one's wandering must never become a "blind and stupid" straying; the experiment must be controlled. Still, did it follow that a controlled experiment should then become all- or overcontrolling? Despite Cassirer's juridical reading of Bacon, Bacon seemed to think not. In his essay De Sapientia Veterum, he confronted the situation. Here the self-proclaimed servant to nature, having tried nevertheless to become its master by claiming God's omnipotent powers, was answered back by nature, the moment nature assumed a Protean, transformative, and restorative agency of its own:

Nevertheless if any skilful Servant of Nature shall bring force to bear on matter, and shall vex and drive it [vexet atque urgeat] to extremities as if with the purpose of reducing it to nothing, then will matter (since annihilation or true destruction is not possible except by the omnipotence of God) finding itself in these straits, turn and transform itself into strange shapes, passing from one change to another till it has gone through the whole circle and ... returns at last to itself. (Bacon $1857-74 \mathrm{c}, 726$, as quoted in Pesic 1999, 86)

It is not completely clear how far Bacon wanted to go in thinking about the intervention of the scientific art into nature; hence the disagreement among his critics. Yet he did seem to argue that if nature could survive the intervention, both sides would get what they wanted: nature would have suffered no harm and experimenters would have got their knowledge. This reading is consistent with one of Bacon's best-known aphorisms from his Novum organum, "Natura enim non nisi parendo vincitur" ([1620] $1857-74,157)$, formerly rendered in English as "Nature to be commanded must be obeyed" (1857-74a, 47) though more recently as "Nature is conquered only by obedience" (2000, 33), leaving it less clear in translation whether it is nature's or our obedience that is in ques- 
tion. Hence, perhaps, the continuing controversy. Perhaps, however, we should be guided by the aphorism that follows the more famous one. For, here, Bacon explicitly awarded nature an internal agency to do what it does independently of what scientists do when they either bring "natural bodies together" or take "them apart" (2000,33).

To be sure, Bacon used a juridical language, as Cassirer says he does, but to what end? Taking Cassirer's lead, some recent critics have compared Bacon's proposed intervention into nature with the rape of a woman. Nature, feminised, is subjected to the experimenters' "shaking," "agitating," "disturbing," and even "hounding," to use Bacon's own words. I think the comparison goes too far. Bacon was plausibly seeking a more modest analogy, likely to the vexing or overstressing of the strings of a musical instrument, in recollection of Plato's description from book 7 of the Republic (531a). For, there, in a debate about the experiments of musical harmonies, the experimenters are heard quarrelling over the measurement of the smallest tones while laying their ears to their instruments as if trying to listen through the wall to their neighbours. In coming so close to the object of their inquiry (though, for Plato, in coming too close), they were forced, so Plato noted, to rack, vex, and torture the strings on the pegs. ${ }^{6}$

Perhaps, however, Bacon was less disturbed than Plato by the proximity. Recall Bacon's description of Salomon's happy sound-house on Atlantis, in which under the kind rule of the king, the experimenters demonstrated "all sounds, and their generation," investigated "harmonies ... of quarter-sounds, and lesser slides of sounds," and transformed on "divers instruments" "small sounds" into ones "great and deep." They even reproduced the "tremblings and warblings" of the beasts and the birds (Bacon [1627] 1999, 182). In Bacon's description, it all sounds very good. In fact, I believe that Cage would have wanted to visit this house, too, to join in the happy experimentation, had it not by 1939 assumed a quite different task. For, having been purchased by the kaiser, it quickly became a place in which the experimentalists determined, through the loudspeaker, to exert control over all who lived there, ultimately taking the lives of those producing the sounds. In Viktor Ullmann's Der Kaiser von Atlantis, composed in Theresienstadt, the experiments produced as experiments in sound fast became experiments in death, just as experiments produced in the name of science fast became experiments in war. With this same trajectory in mind, Horkheimer and Adorno described the late catastrophic culmination of a tendency whose beginnings they also found in early modern science:

The "many things" which, according to Bacon, knowledge still held in store are themselves mere instruments: the radio as a sublimated printing press, the dive bomber as a more effective form of artillery, remote control as a more reliable compass. What human beings seek to learn from nature is how to use nature wholly to dominate both nature and human beings. Nothing else counts. Ruthless toward itself, the Enlightenment has burnt [ausgebrannt] every last trace of its own selfconsciousness. (Horkheimer and Adorno 2002, 2 [transl. amended]; [1947] 1981, 20)

6 For more on Platonic themes in Bacon and his experiments in music, see Pesic (1999); Gouk (1999). 
In recent work in the history of science, Peter Pesic (also a historian of music) has done much to explode the Baconian myth that Bacon was nature's first torturer. Following Pesic's reading, to speak of vexing nature is not automatically to speak of torturing it. Apparently, Bacon went to considerable lengths not to confuse the two types of language. He wrote of his own disapproval of torture, be it of nature, man, or animal, where torture was defined as physical abuse or as excessive and wrongful force, the kind, Bacon noted, one found in contemporary pursuits of justice. To the contrary term "vexation" Bacon attached only the straining and worrying of mental activity on the part of the experimenter who, in coming to know nature, took it to the extremes of transformational variation without yet attempting to insert the experimental knife. We vex our minds as we do the strings of our instruments-for the sake of hearing the secret harmonies of the world.

Bacon conceived of his experimental task, then, less to enter than to come as close as possible to nature, to discover its "genuine forms." Yet because these forms were "hidden in the depths and not easily discovered," experimenters, he realised, had to dig deep beneath the surface (Bacon 2000, 142). One might say, the body of nature, as of an instrument, has to resonate if it is to sing. To reveal nature's depths was thus to reveal its mysteries or secrets. Given these thoughts, the Baconian experimentation approximated disclosure, where disclosing nature was far from torture and far more truthful. Whereas torture only produces false confessions, Bacon argued, nature's necessary vexation produces truth. Of this fallacy of false confession, he insisted, it is one thing to put nature in a handcuff, another to fracture its vessels (Bacon $1857-74 \mathrm{~b}, 42 \mathrm{O}-21) .{ }^{7}$ Many critics have not been able to see the difference, although others have, and when they have, they have seen respect more than rape to be the ideal of the legitimate experimenter. Even wanting to "handcuff" or "interrogate" nature, the act must not reach a tortured extreme. Perhaps the difference is too subtle; certainly how one reads the difference-as making enough or not enough of a difference-makes all the difference to how one responds to the Baconian act.

When Bacon wrote of handcuffs as legitimate and torture as illegitimate, he urged that a little something be preserved in his method of the magician's art:

Neither am I of opinion, in this History of Marvels, that superstitious narrations of sorceries, witchcrafts, dreams, divinations, and the like, where there is an assurance and clear evidence of the fact, be altogether excluded. For it is not yet known in what cases, and how far, effects attributed to superstition do participate of natural causes; and therefore howsoever the practice of such things is to be condemned, yet from the speculation and consideration of them light may be taken, not only for the discerning of the offences, but for the further disclosing of nature. (Bacon [1605] $1857-74,331)$

7 Cf. a parallel claim increasingly made in the eighteenth century, that because nature's forms do not appear directly, with distinction and clarity, they should be investigated by the indirect means of art. This claim matches Bacon's idea that art gives away its secret more willingly than nature. For Adorno, later, it then follows that the less art chooses to give away its secret, the more it takes nature's side. 
The potentially confusing phrase (in the English) is "light may be taken." If read as "throwing light on the matter," then the superstitious narrations will disclose something of nature, whereas if read as "lightly" in the sense of "not counting for much," then such narrations should be ignored. Bacon meant the former, given the logic of the subsequent passage, in which he distinguishes true from "impertinent" narrations based on superstition regarding "the prodigies and miracles of religions" (ibid., 331-32). Embracing something of "the history of marvels," the new science, he nevertheless insisted, should avoid the dogmatism inherent in too many narratives of natural religion produced in his time.

Pesic notes, following Cassirer, that Bacon was concerned to differentiate himself from his predecessors. In this context, Bacon (ibid., 331) rejected the sort of speculative or uncontrolled mode of inquiry that yielded more satisfaction of "the appetite of curious and vain wits" than knowledge proper. Nonetheless, to control the experiment was still not to overcontrol it. It had only to retain or establish criteria for the rigorous assessment of evidence. For Bacon, repeatability offered one such criterion and lay, as I would put it, at the experimental core of his experiment. To make the point, he used an undeniably aggressive, if not inquisitorial, language: "hounding Nature in her wanderings [is] to be able to lead her afterwards to the same place again" (ibid.). Still, this sentence arguably captures two things: first, that the hounding of nature can be repeated; but second, that after the hounding, nature returns to where it began as if it had suffered no harm. (The question is whether it really had.) With this sentence, Bacon seemed only to differentiate himself from the sort of experimenter, who, arguably like Cage, preferred to go astray or to let what happens just happen. Bacon favoured control, though for this he assumed full responsibility. When an experiment goes wrong, he argued, the experimenter, not nature, must be blamed. What errs in experimentation is usually the prejudicial mind, he reminded us, that constantly gets in the way of reliable observation.

Was Cage's attitude, I now want to ask, really so different from Bacon's? When Cage wrote of liberating music, he asked for a release of the mind from intention and attachment. Yet, arguably, all he wanted to release the mind from was an attachment to a Western or European tradition that had allowed composers to compose too determinately their works prior to the act of performance.

To let what happens just happen might just have referred to what had thus far not been allowed to happen in the traditional concert hall. Read this way, his argument for the release from intention approaches Bacon's argument for cleansing the mind of its prejudices or "idols," as Bacon used the latter term, idols that subverted the truthful observation of nature. Whether nature was made the subject of Western science or of Western art, the sort of subjection wanted by Bacon and Cage seemingly suggested nothing harsher than a delicate balance between freedom and control.

This is all very well, but the questions are not all answered. For, one might still maintain that, given the distance of time, Cage went to an extreme of freedom in reaction precisely to the extreme of control for which the Baconian experiment was held responsible. And one may maintain this even if both theorists were really more reserved, neither relinquishing all control in their pursuit of 
knowledge nor yet intervening in nature at the extreme of torturous abuse. My purpose, now, is to distinguish between a harsher and a more charitable reading of their work in order to distinguish the sort of critique that focuses on historical tendencies from that which concerns itself with the specificities of particular views. I started with the former, moved to the latter, and now I return to and remain with the former for the remainder of this essay. Henceforth, I show what is at stake in reading theorists against their own grain or in the light of their reception. For this, I turn to Adorno, not because he reads these theorists charitably but precisely because he does not. Reading them at the extreme, he shows why it matters that we distinguish the history of the concept of the experiment from that of the experimental.

In presenting Adorno's arguments, I show how far modern science, society, philosophy, and art have come to share a set of concerns such that it would be mistaken to conclude that the experiment always takes the side of science and society and experimentalism always the side of art. However, though insisting on this, I present only those arguments of Adorno that are offered against artistic experimenters. For more in antithesis to these than to any others are we told something about his own version of experimentalism. Nevertheless, that I introduce this restriction does not mean (as it never means for Adorno) that his claims apply only to art.

\section{ADORNO}

Adorno argues that at enlightenment's end, the Baconian extremes of the controlled experiment moved full circle to meet the Cagean extremes of experimental freedom, and when they met they did so in an authoritarian space. Why it was an authoritarian space is what his dialectical arguments of history are meant to show. Accordingly, he insists, when Cage called for relinquishing human control over nature to remove from the musical world its artificial or bourgeois constraints, he really re-established complete control-and now comes the clout - much as the Nazis established control when they claimed an immediate relation to nature to justify the eradication from their society of all its unwanted and unnatural elements. Or, when Cage claimed to reach nature, his liberated music sounded nothing like the song of the birds but resembled far more the music composed with and for the most advanced technologies of his day.

Adorno is not always critical of Cage, as he is not always critical of Bacon or, indeed, of the most advanced, serialist composers. Still, he is emphatic when it comes to exemplifying the regressive tendencies of enlightenment, which is almost always his chosen task. Consequently, he maintains, because what "appears not to be made is of course all the more made," those artists (from the most surrealist to the most aleatoric) who rely on "absolute involuntariness" end up converging with the artists they most oppose: namely, those who rely on totally integrated construction (Adorno 1997a, 26 [transl. amended]; 
1970, 47). ${ }^{8}$ By dismantling claims of naturalness by showing the dependence of natural appearances on controlled human design, Adorno demonstrates not only his allegiance to Kant but also his own dialectic (most extremely worked out in Philosophy of New Music), between the progressive tendencies of serialism and the regressive tendencies of naturalism, each supporting a false side of a single, modern coin.

In another argument, Adorno claims that Cage went too far in his rejection of the work concept and thus failed to challenge successfully its authority. Rather than abandoning or even opening up the concept completely, one would achieve more, Adorno insists, were works performed critically to reveal the work concept's contradictions. To reveal these contradictions-say, the work's competing claims to authority and freedom-would be most productive because it would help save the concept against its own worst authoritarian tendencies and redirect it toward a more truthful use.

Another option would be for composers to challenge the concept by producing what Adorno effectively describes as antiwork works of New Music: "Today, the only works that count are those that are no longer works" (Adorno 2006, 30; [1949] 1975, 37). Such works, he believes, Schoenberg produced long before Cage consciously engaged in the attempt to produce something like (in my terms) antiwork nonworks of anti-Western music. For, what Schoenberg achieved with his works was the understanding that, even when composers exert control over the composition, no controlling assumption is (or ever was) made that anyone knows how works sound prior to their sounding-out in performance. In this way, Schoenberg's works, as all great works, work against the work's authoritative claim fully to determine the performances in advance:

\begin{abstract}
The idea that the composer is able to imagine every detail in advance is a legend that every composer finds refuted when he hears his own orchestrated sounds for the first time.... The tension between what is imagined and what cannot be foreseen is a vital element of the New Music. But in being a vital element, it cannot be turned into an equation that has resolved the tension in one direction or another. (Adorno 1992, 303 [transl. amended]; [1963] 1978, 523)
\end{abstract}

In his obituary essay on Schoenberg, Adorno remarks on how often his music was reproached for being "experimental." The idea was that Schoenberg broke so extremely with the musical tradition that he refused any continuity. That this might be a false view of both Schoenberg's music and his intention is obvious. Still, Adorno wants to show how the concept of the "experimental" came increasingly to be used maliciously against any modern composer who allegedly "sinned" against music or succumbed, to use the critics' words, to producing "vain" or "impotent" works that refused any organic relation to the tradition. However, rather than defending the attacked composer by showing

8 Cf. Horkheimer's $(1974,98)$ remark: "The illusion of performative freedom is belied by the instructions produced, where instead of allowing spontaneity within a score, one is constantly following impersonal instructions as driving instructions on a road." For other critical writings on experimental music, see Ballantine (1977); Boulez (1986, especially chap. 42); Metzger (1961); Nyman (1999); Palombini (1993); Smalley (1975). 
that he did maintain an organic relation to the tradition, Adorno criticises the very notion of an organic (harmonious) relation. Such a relation, he insists, has been belied by every great composer who has ever belonged to the tradition of Western music. Schoenberg belonged to a tradition in which what "went before" was overthrown by moving on according to a development of music's material and form. From this Adorno concludes with all the dissonance of his dialectic, that tradition is present "far more in works deplored as experimental" than in works either deliberately striving to be traditional or claiming to have nothing to do with tradition at all (Adorno [1967] 1981, 154-55 [transl. amended]; 1997b, 10.1:160).

If the experiment can go wrong at its extreme, the experimental can, too. This point is crucial. If music encourages too much immediacy, chance, or indeterminacy, to use Cage's own experimental language, it ends up floating, Adorno now argues, in a random and purposeless space of becoming. This might have been a very good thing for Cage but is very bad for Adorno, just because no criteria are any longer forthcoming to tell right from wrong or true from false. A space of becoming serves no one if it is guided by an "anything goes" principle. If a purposeless space is dangerous, then equally dangerous, in Adorno's view, is the consequence that seems to follow from Cage's purported total destruction of the imaginary walls of the musical domain - the destruction of not only the work concept but also the very concept of music. For what Cage allegedly achieved with this destruction was to get rid of one side of the relation between humanity and nature that his experimentalism was meant to preserve-the side of humanity. If nature or sound was left to itself because all intentionality had been laid aside, then what was betrayed was what was claimed most to be wanted-the retrieval of the relation.

Adorno does not read Cage as I do. I read Cage as wanting to relinquish one kind of human intentionality in favour of developing another, styled according to Eastern doctrines of chance and discipline (which may arguably be no better). Nevertheless, Adorno is completely justified in asking how artistic intention expresses itself through chance and whether Cage offered sufficient criteria for assessing his productions. However one reads Cage, in other words, Adorno's questions remain trenchant against a too-open positioning or, perhaps one should say, a too-open nonpositioning of art.

It makes no sense in Adorno's view to ask artists to relinquish their intentional involvement with art. Since, when they do that, to reach nature in her immediacy, they usually end up with more human artifice-not less-and with just the sort of artifice forever severed from the nature they claim to want to touch. The longing to touch recalls the nostalgia with which this chapter began: that of alienated listeners who, longing to know what it feels like to be in real contact with music (whatever that means), displace their appreciation onto what, sometimes by their own admission, is a dead, empty, and outdated ritual.

With Cage, Adorno writes much about indeterminacy, spontaneity, and openness. However, he refuses to rationalise these elements of experience by purified appeals to nature. In a passage titled "Das Experiment," he argues for 
the necessary mediation of human consciousness in nature, which means for present purposes the mediation of art (Adorno 1997b, 18:26-27). If we come to know something about nature, it is not because nature directly reveals itself to us but because a certain form of experimental art does something to crack through the social fabric that holds nature apart from us in the first place. To come to see nature through art is to see nature as damaged as art: beautiful nature is not simply waiting in the background to be rediscovered. To see nature this way is falsely to assume that nature exists in an autonomous sphere separated from humanity, a violent assumption that lies at the root of the modernist problem. Once, in describing the passage of enlightenment to catastrophe, Adorno concluded with John Dewey that what we need is more or better enlightenment, not less. The conclusion in the present argument is similar: if we want to re-establish our relation to nature, what is needed is more art and more experimental antiwork works of art. Or, against the dominant experiments produced in contemporary laboratories, what is needed is more genuine experimentalism.

What, now, does Adorno mean to capture by speaking positively of experimentalism? In his view, all genuinely New Art is experimental, which, to recall, is what Edgar Wind claimed, too. Whereas, however, Wind slid (at least in the passage I quoted) from the experimental to the experiment, Adorno more adamantly preserved the difference. One way he did this is by developing what in the 195 os Pierre Schaeffer pursued under the heading "vers une musique expérimentale." Following Heinz-Klaus Metzger, Adorno pursued instead "une musique informelle," where the idea of music's being or becoming informelle was meant to subvert the authoritarian production of music of their day. Only through experimentalism does art have any possibility of achieving a new comportment or posture that refuses to capitulate to the social or formal powers of administration. Only experimental works maintain their distance from the two deadening extremes-first, from a society that insists on constraint at the expense of freedom and, second, from an art that insists on complete freedom at the expense of constraint.

Experimentalism implies risk, failure, and, in tandem, the recognition that a society that promises security usually gives its members anything but. Of the literary and musical experiments of the German artist Hans G. Helms, he remarks that "the defamatory word "experiment" might be returned to its "positive sense" only if "experimental art" is allowed not to be "secure" (Adorno 1991-92, $\left.2: 103 ;\left[195^{8-74}\right] 1974,440\right)$. Only those works prepared to "expose themselves to every risk" have a chance of "surviving" or of having an "afterlife" (Adorno $\left.1997 \mathrm{a}, 34 ; 1970,5^{8}\right) .9$ To produce a work that plays safe with the tradition is doomed from the outset to fall into oblivion, its failure being guaranteed by its own aim. The only chance a work has to survive is if, in not conforming, it shows that it is prepared to take a risk, to be unsure (unsicher). That it is prepared to take a risk, however, does not guarantee its success. It offers only the chance or possibility of survival: "The experimental [Das Experimentelle] is not

9 Adorno uses two terms, überleben (to survive) and Nachleben (afterlife). 
automatically within the truth; it can equally well end in failure, otherwise the concept of the experiment [der Begriff des Experiments] has no reasonable meaning" (Adorno 2002, 651 [transl. amended]; 1997b, 17:262). Here, one should note the deliberate move from the term "experimental" to "the concept of the experiment," to see Adorno's attempt to return to the latter what the former still connotes.

In Adorno's judgement, Cage did not take the risk. All he did was try to guarantee success by aligning his production with dubious philosophical claims about chance, but he took no risk within the production itself. This argument matches an argument against conceptualism, according to which works, despite their success, do not survive when they willingly relinquish aesthetic appearance in favour of identification with, or subsumption by a concept. Between the claim to be experimental and the production of experimental art clearly lies all the dialectical difference in the world, the difference between art's genuine survival and a work's either commercial or conceptual success.

Adorno's experimentalism is about trying out new possibilities within the arts. However, this idea is tempered by the recognition that, as an artist, one might well become more interested in experiments than in producing experimental art. When, as allegedly with Cage, the experimenters stressed the unforeseeable nature of the outcome, the works they produced ended up being of no surprise at all. How can a production genuinely surprise, Adorno asks, if there is nothing any longer at stake in what a composer decides to do or if no gap remains between what an experimentalist wants to prove and what is proved, because, in these cases, nothing counts as either a proof or a disproof of what the experimenter sets out to prove? In an argument similar to that of Karl Popper, Adorno describes the dangers of an experiment over which the experimenter exerts complete control so that nothing, according to design or decree, can go wrong. Only works that are not so controlled, and thus assume something like an agency of their own, are the ones that retain the real potential to surprise:

\footnotetext{
The avant-garde ... calls for a music which takes the composer by surprise, much as a chemist can be surprised by the new substance in his test-tube. In future, experimental music should not just confine itself to refusing to deal in the current coin; it should also be music whose end cannot be foreseen in the course of production. In genuine experiments there has always been something of a surplus of that objectivity over the production process. (Adorno 1992, 302-3; 1997b, 16:523)
}

Adorno notes how often genuine experimentalists tend to prejudge their works failures because they are so aware of the risks they take. Yet, in so judging their works, they often end up conceding what the enemies of the New Music most like to tell them: that had they only played safe, they would have been assured of success. In Adorno's view, there is a tendency, even among the most committed of experimentalists, to conform to what society demands of its music and musicians. What threatens us today, he remarks, is not, unfortunately, experimental art but, rather, its domestication or conformism, which transforms the threat into no threat at all (Adorno 1997b, 19:631; 1997a, 37-39; 1970, 62-65). 
This argument recalls another that Adorno often offered, regarding composers who declare their music difficult or incomprehensible even if in its construction it is entirely coherent and consistent. Why is it necessary to apologise for making thoughts, be they philosophical or musical, hard for readers and listeners? To declare one's work difficult is to give the audience the immediate opportunity to agree. From which it follows that one should know what one is saying when one apologises. Or, as Stanley Cavell has made the point, one should understand what one means when one says what one says (see Cavell 1969). This is not merely a platitude. Nor is the point to encourage a philosophical form of moralising over a society that apparently does not want to think or mean with its words. The point is intended to demonstrate the genuine difficulty either of writing philosophy or of composing music that does not immediately accommodate ears that tend to prefer to be accommodated. For Adorno, as for Cavell, to stress the genuine risk and fragility involved in the modernist project is one way to capture the sort of difficulty that really or philosophically matters.

Adorno's preferred experimentalism is distinct from what he takes to be Bacon's human hounding and Cage's human silence, even if, as I have shown, it actually absorbs many elements of both. Hence, he recognises the necessary role that violence plays in what is for him, dialectically, a silent form of art. The violence of experimental art is the violence only of the inward refusal or withdrawal of art to conform to the more violent violence of a society in which the art necessarily exists and to which it therefore responds. Adorno differentiates his own encouragement of explosions, shocks, and fireworks from those of the Futurists, surrealists, or aleatorists whom, he contends, tend to celebrate such things only "for their own sake." His encouragement is offered, contrarily, just to the extent that the explosions might help shatter society's totalising myths or idola theatric, as he writes clearly in reference to Bacon. To the violent world one shouldn't contribute more violence, even if one sort of violence (produced with extreme gestures and exaggerations, perhaps) is needed to dampen the power of another. This is an endorsement not of the "eye for an eye" principle, only of the idea that art must genuinely respond to a society from which it cannot separate itself.

Genuine shocks, in Adorno's view, are such as to explode the untruth of the increasingly authoritative works and the authoritarian society in which they are produced. Totalising myths concerning art, nature, or personal happiness conceal their violence through aesthetic appearance in ways similar to how explanatory formulas tend to mask the very thing that needs explaining. The myths must be exploded by suitably explosive works, which, as he puts it, more truthfully show their own "scars of damage and disruption" (Adorno 1997a, 23; 1970, 41). To bear one's scars, as soldiers might bear their scars, is one way to shatter the myths of victory to break out of "the closed confines" of what seemingly has come to be accepted as acceptable modes of conduct in society at large (ibid). To explode the myths is to implode the myths, to reveal the barbaric history hidden behind illusions of harmony. To make art explosive is to invest both the works and the myths with a "self-imploding" or "antitraditional energy" (ibid. 
[trans. amended]; see also Adorno [1966] 1972, 92; [1976] 1988, 223; [1962] 1973, 427):

Even tranquil works ... discharge not so much the pent-up emotions of their makers as the works' own inwardly antagonistic forces. The result of these forces is bound up with the impossibility of bringing these forces to any equilibrium; their antinomies, like those of knowledge, are unsolvable in the unreconciled world. The instant these forces become image, the instant what is interior becomes exterior, the outer husk is exploded; their apparition, which makes them an image, always at the same time destroys them as image. (Adorno 1997a, 85 [transl. amended]; 1970, 131-2; see also Adorno [1966] 1972, 92)

Adorno looks to experimental art not to escape from "the crisis of experience" but to confront it. He asks repeatedly whether experience is possible in a world on which the most deadly experiment has been performed. He thinks it is, though only if it follows the terms of his negative dialectic. For such terms try to maintain as a live and constant question whether, in fact, any experimental art, science, or philosophy is, indeed, genuinely experimental. In experimentalism, he finds a form of explosion that is sometimes loud and harsh in appearance but still metaphysically silent, given its withdrawal from contemporary conventions and structures of meaning. To withdraw is to refuse to communicate or to be complicit, while yet remaining answerable to questions regarding truth. All this suggests the sort of silence that is heard in self-imploding works. These are works that allegedly have a chance of doing genuine violence to the world of established social myths. Why is Adorno so convinced that Cage's most famous work of silence did not achieve even a little of this?

Adorno underscores how fragile the conditions are under which an artwork, a scientific theory, or his own experimental critique in philosophy is produced as experimental. Truth is fragile and has only the smallest chance of survival. An experimental act usually ends up as an experiment. The idea of fragility is crucial and returns us to the question with which I began: whether our appreciation of experimentalism should be quiet or loud. I think Adorno similarly wonders whether explosions have always to result in noise or whether, in preserving the character of the experimental, they have a chance of retrieving something of the fragility of thought characteristic of experience before the moment of, and during the long passage toward, its crisis. Fragility though violence as smiling through tears: Is this not what Adorno aims precisely to save in the original Baconian attitude?

\section{CONCLUSION}

I have focused on the distinction between the experiment and the experimental. However, the point was not to come out in favour of one rather than the other. For that would be to assume that they are, in fact, different concepts rather than two sides of a single coin that has tended to flip on to one or other of its sides the more or less assertively it has spun in different domains. It would equally be in error to assume that the experiment belongs more to the disci- 
pline of science or politics and experimentalism more to art, even if it might seem that way given the form of my argument. With Adorno, my idea was to capture the sense of what is lost in experiments when they become too controlled and of what is lost in experimentalism when it travels too superficially under the naturalising banner of freedom from human constraint. Still, I tempered and even complicated Adorno's interpretations of Bacon and Cage by presenting their views as they were offered and not only in light of their most extreme tendencies. Bacon was not completely a Baconian scientist as Cage never became entirely a Cagean in matters of art.

More than being concerned to judge these theorists, my overall aim was to describe their views as responses to a perceived crisis of experience that, in turn, gave rise to a long and complicated history of the concepts of the experiment and the experimental. Whether, in the end, we have two concepts to deal with or one seen from two different sides matters less to me than my having shown what is at stake in the history in which experimentalism and the experiment have played - and continue to play - so central a role. In philosophy, society, science, and the arts, the antagonism that keeps the different impulses of the concept(s) alive-mostly in negative affinities-need no longer pass us by without account.

\section{REFERENCES}

Adorno, Theodor W. (1949) 1975. Philosopie der Neuen Musik. Edited by Rolf Tiedemann. Vol. 12 of Gesammelte Schriften. Frankfurt am Main: Suhrkamp. First published 1949 as Philosophie der neuen Musik (Tübingen: Mohr). Translated by Robert Hullot-Kentor as Adorno 2006. . (1958-74) 1974. Noten zur Literatur.

Edited by Gretel Adorno and Rolf Tiedemann. Vol. 11 of Gesammelte Schriften. Frankfurt am Main: Suhrkamp. First published $195^{8-74}$ as Noten zur Literatur I-IV (Frankfurt am Main: Suhrkamp). Translated by Shierry Weber Nicholsen as Adorno 1991-92. - (1962) 1973. Einleitung in die Musiksoziologie. In Dissonanzen; Einleitung in die Musiksoziologie, edited by Rolf Tiedemann, vol. 14 of Gesammelte Schriften. Frankfurt am Main: Suhrkamp. First published 1962 as Einleitung in die Musiksoziologie: Zwölf theoretische Vorlesungen (Frankfurt am Main: Suhrkamp). Translated by E. B. Ashton as Adorno (1976) 1988. - (1963) 1978. Quasi una Fantasia. In Musikalische Schriften I-III, edited by Rolf Tiedemann, vol. 16 of Gesammelte Schriften. Frankfurt am Main: Suhrkamp.
First published 1963 as Quasi una fantasia: Musikalische Schriften II (Frankfurt am Main: Suhrkamp). Translated by Rodney Livingstone as Adorno 1992. -. (1966) 1972. "Postscriptum." In Soziologische Schriften I, edited by Rolf Tiedemann, vol. 8 of Gesammelte Schriften, 86-92. Frankfurt am Main: Suhrkamp. - (1967) 1981. Prisms. Translated by Samuel and Shierry Weber. Cambridge, MA: MIT Press. First published 1955 as Prismen: Kulturkritik und Gesellschaft (Frankfurt am Main: Suhrkamp). This translation first published 1967 (London: Spearman). ___ 1970. Ästhetische Theorie, edited by Gretel Adorno and Rolf Tiedemann. Vol. 7 of Gesammelte Schriften. Frankfurt am Main: Suhrkamp. Translated by Robert Hullot-Kentor as Adorno 1997a. - . (1974) 1978. Minima Moralia: Reflections from Damaged Life. Translated by E. F. N. Jephcott. London: Verso. First published $195^{1}$ as Minima Moralia: Reflexionen aus dem beschädigten Leben (Frankfurt am Main: Suhrkamp). This translation first published 1974 (London: New Left Books). 


\section{Explosive Experiments and the Fragility of the Experimental}

(1976) 1988. Introduction to the Sociology of Music. Translated by E. B. Ashton. New York: Continuum. First published 1962 as Einleitung in die Musiksoziologie: Zwölf theoretische Vorlesungen (Frankfurt am Main: Suhrkamp). This translation first published 1976 (New York: Seabury Press).

. 1977. "The Actuality of Philosophy." Telos 31: 120-32. Delivered as a lecture titled "Die Aktualität der Philosophie" on 7 May 1931, first published in vol. 1 of Gesammelte Schriften, edited by Rolf Tiedemann (Frankfurt am Main: Suhrkamp, 1970-86).

. 1991-92. Notes to Literature. Edited

by Rolf Tiedemann. Translated by Shierry Weber Nicholsen. 2 vols. New York: Columbia University Press. For further bibliographic information, see Adorno (1958-74) 1974 .

. 1992. Quasi una Fantasia: Essays on

Modern Music. Translated by Rodney Livingstone. London: Verso. For further bibliographic information, see Adorno (1963) 1978.

.1997a. Aesthetic Theory. Translated by Robert Hullot-Kentor. Minneapolis: University of Minnesota Press. First published as Adorno 1970.

- 1997 b. Gesammelte Schriften. Edited by Rolf Tiedemann. Rev. ed. 20 vols. Frankfurt am Main: Suhrkamp.

. 2002. Adorno: Essays on Music. Edited by Richard Leppert. New translations by Susan H. Gillespie. Berkeley: University of California Press.

-. 2006. Philosophy of New Music.

Translated by Robert Hullot-Kentor.

Minneapolis: University of Minnesota Press. For further bibliographic information, see Adorno (1949) 1975.

Apollonio, Umbro, ed. (1973) 2001. Futurist Manifestos. Translated by Robert Brain, R. W. Flint, J. C. Higgitt, and Caroline Tisdall. Boston: Museum of Fine Arts. First published 1970 as Futurismo (Milan: G. Mazzotta). This translation first published 1973 (London: Thames and Hudson).

Bacon, Francis. (1605) 1857-74. The Advancement of Learning. In The Works of Francis Bacon, edited by James Spedding, Robert Leslie Ellis, and Douglas Denon
Heath, 14 vols., 3:253-492. London: Longman. First published 1605 as Of the Proficience and Advancement of Learning, Divine and Humane (London: Henrie Tomes).

-_—. (1605) 2001. The Advancement of Learning. New York: Random House. First published 1605 as Of the Proficience and Advancement of Learning, Divine and Humane (London: Henrie Tomes). This edition first published 1851 (London: Pickering).

-. (1620) 1857-74. Novum organum.

In The Works of Francis Bacon, edited by James Spedding, Robert Leslie Ellis, and Douglas Denon Heath, 14 vols., 1:70-366. London: Longman. First published 1620 as Novum organum scientiarum (London). - (1627) 1999. New Atlantis. In Three

Early Modern Utopias: Utopia; New Atlantis; The Isle of Pines, edited by Susan Bruce, 149-86. Oxford: Oxford University Press. First published 1627 as an appendix to Sylva Sylvarum (London: W. Lee). - 1857-74a. The New Organon. In The

Works of Francis Bacon, edited by James Spedding, Robert Leslie Ellis, and Douglas Denon Heath, 14 vols., 4:37-248. London: Longman. First published 1620 as Novum organum scientiarum (London). . 1857-74b. Of the Dignity and Advancement of Learning. In The Works of Francis Bacon, edited by James Spedding, Robert Leslie Ellis, and Douglas Denon Heath, 14 vols., 4:273-498. London: Longman. First published 1623 as De dignitate et augmentis scientiarum (London: Haviland), a Latin translation and expansion of $O f$ the Proficience and Advancement of Learning, Divine and Humane (see Bacon [1605] 1857-74).

- - 1857-74c. Of the Wisdom of the Ancients. In The Works of Francis Bacon, edited by James Spedding, Robert Leslie Ellis, and Douglas Denon Heath, 14 vols., 6:687-764. London: Longman. First published 1609 as De sapientia veterum (London: R. Barker). . 2000. The New Organon. Edited by Lisa Jardine and Michael Silverthorne. Cambridge: Cambridge University Press. First published 1620 as Novum organum scientiarum (London). 
Ballantine, Christopher. 1977. "Towards an Aesthetic of Experimental Music." Music Quarterly 63 (2): 224-46.

Bossy, John. 1996. “'Torturing the Truth': Is There a Connection Between Bacon's Science and His Statecraft?" Times Literary Supplement, 11 October, 3-4.

Boulez, Pierre. 1986. Orientations: Collected Writings. Edited by Jean-Jacques Nattiez. Translated by Martin Cooper. Cambridge, MA: Harvard University Press. First published 1981 as Points de repère, revised 1985 (Paris: Christian Bourgois).

Cage, John. 1961. Silence: Lectures and Writings. Middletown, CT: Wesleyan University Press.

Cassirer, Ernst. 1953. The Platonic Renaissance in England. Translated by James P. Pettegrove. Austin: University of Texas Press. First published 1932 as Die platonische Renaissance in England und die Schule von Cambridge (Leipzig: Teubner).

Cavell, Stanley. 1969. "Music Discomposed." In Must We Mean What We Say? A Book of Essays, 180-212. New York: Scribner.

Cohen, Peter, dir. 1989. The Architecture of Doom. New York: First Run Features, FRF 909211D, DVD.

Goethe, Johann Wolfgang von. (1810) $195^{8}$. Zur Farbenlehre: Polemischer Teil. Edited by Rupprecht Matthaei. Vol. 5 of Die Schriften zur Naturwissenschaft. Weimar: Böhlau. First published 1810 (Tübingen: Cotta).

Gouk, Penelope M. 1999. Music, Scienceand Natural Magic in Seventeenth-Century England. New Haven, CT: Yale University Press.

Gross, Alan G. 1990. The Rhetoric of Science. Cambridge, MA: Harvard University Press.

Horkheimer, Max. 1974. Eclipse of Reason. Rev. ed. New York: Continuum. First ed. published 1947 (New York: Oxford University Press).

Horkheimer, Max, and Theodor W. Adorno. (1947) 1981. Dialektik der Aufklärung: Philosophische Fragmente. Edited by Rolf Tiedemann. Vol. 3 of Gesammelte Schriften. Frankfurt am Main: Suhrkamp. First published 1944 as Philosophische Fragmente (New York: Social Studies Association); revised as Dialektik der Aufklärung: Philosophische Fragmente, first published 1947 (Amsterdam: Querido Verlag). Translated by Edmund Jephcott as Horkheimer and Adorno (2002).
- 2002. Dialectic of Enlightenment: Philosophical Fragments. Edited by Gunzelin Schmid Noerr. Translated by Edmund Jephcott. Stanford: Stanford University Press. For further bibliographic information, see Horkheimer and Adorno (1947) 1981.

Marx, Karl, and Friedrich Engels. 1975-2004. The Holy Family, or Critique of Critical Criticism: Contra Bruno Bauer and Company. In Marx, Engels: Collected Works, [translated by Richard Dixon et al.], $5^{\circ}$ vols., 4:5-211. New York: International Publishers. The Holy Family first published 1845 as Die heilige Familie, oder Kritik der kritischen Kritik: Gegen Bruno Bauer und Consorten (Frankfurt am Main: Literarische Anstalt).

Mathews, Nieves. 1996. Francis Bacon: The History of a Character Assassination. New Haven, CT: Yale University Press.

Merchant, Carolyn. 2006. "The Scientific Revolution and The Death of Nature." Isis 97 (3): 513-33.

Metzger, Heinz-Klaus. 1961. "Abortive Concepts in the Theory and Criticism of Music.” Translated by Leo Black. Die Reihe 5 (English edition): 21-29.

Nyman, Michael. 1999. Experimental Music: Cage and Beyond. 2nd ed. Cambridge: Cambridge University Press. First ed. published 1974 (London: Studio Vista). Palombini, Carlos. 1993. "Pierre Schaeffer, 1953: Towards an Experimental Music." Music and Letters 72 (4): 542-57.

Payton, Rodney J. 1976. "The Music of Futurism: Concerts and Polemics." Musical Quarterly 62 (1): 25-45.

Perloff, Nancy. 2002. "John Cage.” In Postmodernism: The Key Figures, edited by Hans Bertens and Joseph Natoli, 62-69. Oxford: Blackwell.

Pesic, Peter. 1999. "Wrestling with Proteus: Francis Bacon and the 'Torture' of Nature." Isis 90 (1): 81-94.

Schiller, Friedrich von. 1967. On the Aesthetic Education of Man in a Series of Letters. Translated by Elizabeth M. Wilkinson and L. A. Willoughby. Oxford: Clarendon Press. First published 1795 as "Über die äesthetische Erziehung des Menschen in einer Reyhe von Briefen” (Die Horen, nos. $1-2,6)$.

Schöne, Albrecht. 1987. Goethes Farbentheologie. Munich: C. H. Beck. 


\section{Explosive Experiments and the Fragility of the Experimental}

Shapin, Steven. (1988) 1999. "The House of Experiment in Seventeenth-Century England." In The Science Studies Reader, edited by Mario Biagioli, 479-504. London: Routledge. First published 1988 (Isis 79 [3]: 373-404).
Smalley, Roger. 1975. "Experimental Music." Musical Times 116 (1583): 23-26.

Wind, Edgar. (1963) 1985. Art and Anarchy. Evanston, IL: Northwestern University Press. First published 1963 (London: Faber and Faber). 


\title{
Omnis ars \\ ex experimentis dependeat
}

\section{"Experiments" in Fourteenth- Century Musical Thought ${ }^{*}$}

\author{
Felix Diergarten \\ Schola Cantorum Basiliensis, Basel
}

\author{
Experimentum quidem enim artem fecit. \\ (Aristotle in the translation of James of Venice) ${ }^{1}$ \\ Fallax experimentum est. \\ (Hugh of Saint Victor) ${ }^{2}$
}

In the larger context of "artistic experimentation," as suggested by this volume, the Latin sentence "omnis ars ex experimentis dependeat" seems to say that "all art depends on experiments." 3 This sentence would then perfectly fit a certain modernist understanding of "the experimental" as an avantgardistic transgression of the systemic artistic restraints of a certain time, as a break with the tradition or authority necessary for artistic creativity. In the following I shall demonstrate, however, not only that this sentence means something quite different but that it could even be understood to mean the complete opposite: an affirmation of tradition and authority. The following text accordingly traces the early history of the term experimentum. In doing so it follows and deepens a line of thought opened up by Lydia Goehr: while Goehr (2008b), in outlining a clear distinction of "the experiment" and "the experimental" for the first time, focused on Francis Bacon, Theodor W. Adorno, and John Cage, the present

\footnotetext{
DOI http://dx.doi.org/10.11116/9789461661883.cho2

* I am grateful to Andreas Speer, Felix Heinzer, and Stephan Herzberg for helping me with questions concerning the translations from Latin and the contexts of late mediaeval philosophy, to Frank Hentschel and Christian Thomas Leitmeir for their critical comments, to Anne Smith (Basel) for helping me with the English version of this essay, and to Lydia Goehr and Pedro Memelsdorff for inspiring comments and discussions in Ghent and afterwards. Translations are my own unless otherwise indicated.

Aristoteles $(1970,5)$

2 Quoted in Haas $(2007,76)$.

3 The subjunctive dependeat is used, not the indicative dependet, because the proposition cum introduces this sentence (see complete text in the appendix).
} 
text traces such affinities in the late Middle Ages, going back, among others, to Francis Bacon's much earlier namesake Roger Bacon. To understand the dialectics of experimentum, to understand the sentence "omnis ars ex experimentis dependeat," we have to understand the epistemological principles behind this sentence, and since the author of this sentence, Johannes de Muris, was a magister of the University of Paris in the early fourteenth century, it will be hardly surprising that these epistemological principles are those of Aristotle.

Johannes de Muris was primarily a mathematician and astronomer. His writings on musical notation and musical proportion, however, were more widely distributed in European manuscripts than those of any other music theorist between 1200 and $1500 .{ }^{4}$ Muris was probably born in the 1290 as Jehan de Murs in the diocese of Lisieux in Normandy, became a student of the artes faculty in Paris, most likely as a resident of the famous Collège de Sorbonne, and finally became a magister of the same institution in 1321 . He seems to have spent the rest of his life as a freelance scholar, turning up here and there in the documents of French towns. In the 1340 os he was invited by pope Clement VI to take part in a conference on a calendar reform. The most striking aspect of Muris's astronomical works has been described by Gushee, Balensuela, and Dean (2001) as "his insistence on testing the tabular predictions of eclipses, equinoxes and conjunctions against careful observation by the naked eye (assisted by instruments)," certainly a practice to which the modern term "experiments" would apply. Regarding his musical writings, however, much doubt remains about the authorship of the numerous treatises ascribed to him. Today, in accordance with the research of Ulrich Michels and Lawrence Gushee, three works are generally ascribed to Muris with certainty: the so-called Notitia artis musicae, the Compendium musicae practicae, and the Musica speculativa. The Compendium (Muris 1972) is a condensed reworking of the Notitia and the Musica speculativa (Falkenroth 1992) is a redacted digest from Boethius that was often prescribed as a textbook in fourteenth- and fifteenth-century universities. Muris was, however, probably not the direct author of the Libellus cantus mensurabilis, which was to become the most famous work transmitted under his name; and several counterpoint treatises ascribed to Muris are probably also misattributed. Muris himself was not a professional musician, or at least did not consider himself as one. Indeed, at the end of his Notitia artis musicae he rather addresses the "venerable musicians" (venerabiles musici), asking them to correct him wherever he failed. Muris continues this captatio benevolentiae by saying that he had nonetheless admired musicians from his early youth ("quos a tota dileximus iuventute"; Muris 1972, 106). He obviously considered himself a musical "amateur," and he might be regarded as an early example of an important species in the history of music theory: the scientist and musical amateur, the "outsider" (to overstate the case a little) who is a music theorist. In his writings Muris actually exhibits a characteristic feature of this social type: a fascinating and sometimes paradoxical combination of veneration for authorities and tradition on the one

4 The following account is based on Gushee, Balensuela, and Dean (2001) and Hentschel (1994-2007). 
hand and of "experimental," utopian ways of thinking beyond the boundaries of contemporary musical thought on the other (Holtmeier 2012, 25).

In the following I will focus on the so-called Notitia artis musicae, one of the most fascinating documents of fourteenth-century music theory. It is a bold, divided, and partly contradictory attempt by an academic music enthusiast to bring issues of contemporary scientific and philosophical thought together with exigent questions of music theory and practice (Muris 1972, 2000; Michels 1970). It survives in ten manuscripts, one of them written for Ghent's St. Bavo Abbey as late as 1503 . Muris's text does not have an original title. When compiling a list of his works, completed in 1321, he referred to his own text as Notitia artis musicae. But he also referred to it as his Summa musicae in a list of the books in his possession he had lent to other people, including Philippe de Vitry. Only in one Parisian copy of the treatise is the work called Ars novae musicae, obviously to draw it into the contexts of de Vitry and his so-called Ars nova (Michels 1970, 2-8). The following text upon the prologus of this work, from which the title of this essay stems, tries to preserve-as far as that is possible - the original character of a lecture given in Ghent in March 2013, namely that of a lectio, a reading in a quite mediaeval sense. As is well known, reading aloud and commenting on authorities such as Aristotle or Petrus Lombardus played an important role in the everyday life of mediaeval universities. ${ }^{6}$ In this tradition, we will read our authority, Johannes de Muris's prologue, line by line and explicate it with our glosses. ${ }^{7}$

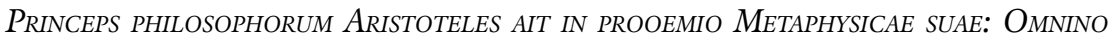
SCIENTIS SIGNUM EST POSSE DOCERE. "Aristotle, the prince of philosophers, says in the prologue to his Metaphysics: In general the ability to teach is a distinguishing mark of those who have knowledge." With his very first sentence Muris refers to the figure who had become without doubt the most quoted authority of thirteenth- and fourteenth-century philosophical discourse: Aristotle, frequently spoken of simply as "philosophus"- " the philosopher." After censorship in the earlier thirteenth century, the complete writings of Aristotle had become standard textbooks in Paris in 1255 (Tuninetti 2011). Aristotelian epistemology was studied in particular from his so-called Analytica priora and posteriora and from parts of the so-called Ethica nicomachea and Metaphysica. Muris's prologue is in fact a gloss on the prologue of the latter, as he openly acknowledges. Muris obviously did not know these writings in the Greek original, but in the thirteenth-century Latin translation by Guilelmus de Morbeka (William of

5 The present chapter focuses on the concept of experimentum in Johannes's Notitia; other fascinating aspects had to be set aside and are extensively described elsewhere. On Muris's relationship to fourteenth-century mathematics, physics, semiotics, and philosophy see Tanay (1989, 1993, 1999); Haas (1974); Gallo (1984).

6 See, for example, Rüegg (1993).

7 The complete text of Muris's prologue, with the quoted passages from Aristotle and a translation, can be found in the appendix. 
Moerbeke, Willem van Moerbeke, c. 1215-86), a Flemish Dominican friar from a town twenty kilometres northeast of Ghent. Morbeka was Latin bishop of Corinth, in Greece, and translated the complete Aristotle from the original Greek (or revised existing translations thereof) (ibid., 430). Muris's quotations from Aristotle's Metaphysica are closer to this specific translation than to any other. The first sentence that Muris quotes from Aristotle's prologue states that a general characteristic of those who have knowledge is the ability to teach. In the synoptic edition of the complete prologue in the appendix, below, the line numbers make it evident that this sentence in fact comes rather late in Aristotle's original prologue: Muris rearranges Aristotle's argument and starts with what originally was one of Aristotle's conclusions, which Muris then sets out to prove. The next lines then explicate and elaborate the opening line.

IN QUALIBET AUTEM ARTE THEORICI DOCERE POSSUNT, PRACTICI VERO NON. "In every ars the theorici know how to teach, the practici not." This sentence is Muris's own gloss and not a quotation. Muris explains the preceding sentence, distinguishing the theorici from the practici, that is, those who have abstract and speculative knowledge from those who primarily have practical knowledge. This is a well-known distinction drawing on different Aristotelian and post-Aristotelian traditions. In Jacobus's ("Leodiensis") words, the aim of scientia theorica or scientia speculativa (which are used synonymously) is cognitio; the aim of scientia practica, however, is the opus (including, to make it short, both the modern "work" and the modern "act"). ${ }^{8}$ Of course it is important to keep in mind that musica practica cannot simply be understood as "musical practice" in a modern sense: everything commonly called "music theory" today (notation, counterpoint, harmony, analysis, solmisation, ear training, etc.) would have pertained to musica practica in the Middle Ages, while musica theorica corresponded to what we today would call "speculative theory" (which is actually a pleonasm of a Greek noun and a Latin attribute meaning the same thing) (Riethmüller 1990, 180). ${ }^{9}$ Musica practica, even if the distinction is far from consistent, is that part of the science of music that examines and regulates aspects of practice, a kind of "applied science," as it were-in any case, not "practice" (in the modern sense of "performance") itself. Muris's Notitia in fact consists of two parts, the first of which (called musica theorica) deals with sound and sounding numbers, the second (called musica practica), with theory and practice of notation. One might question, then, returning to Muris's sentence, whether practici in this context really refers to "practitioners" in anything close to a modern sense. The context, however, makes it clear that Muris's term practici does not only refer to the representatives of an academic discipline concerned with musica practica. First of all, the statement that the practici are not able to teach separates them distinctively from those with theoretical knowledge. And then, as the next sentences make clear, Muris identifies the practici with the experti, those who have "experience"

8 Speculum musicae 1.18 [Jacobus 1955-73], quoted in Harne (2010, 16). See footnote 18 below for literature and further background of this distinction.

9 The distinction is far from consistent and clear in the Middle Ages. See also, Hentschel (2000, 197-211); Haas (2007). 
without theoretical reflection. The difference between theorici and pratici here assumes the function of the common distinction between the educated musicus and the experienced cantor, the musician exercising basic skills. ${ }^{10}$

EXPERTI ENIM IPSUM QUIA SCIUNT, SED PROPTER QUID NESCIUNT. "For the eXperti know the 'that' but not the 'because." Here the practici are substituted by experti, that is: the experienced. They know "that" (quia) without knowing "why" (propter quid); they have implicit knowledge. At this point a little digression into Aristotelian epistemology is necessary (see figure 1) ${ }^{11}$ At the end of his Analytica posteriora, Aristotle made the well-known statement that all knowledge takes its beginnings from sensation, aisthesis in the original Greek, mostly translated with the Latin term sensus in the Middle Ages. ${ }^{12}$ By means of memory and by means of comparison, sensations become experience-in Greek, become empereia. And for this there were two Latin translations that were common in Muris's times, experientia and experimentum. Experimentum, then, in mediaeval Latin is a synonym for "experience," and we shall see shortly that Muris indeed uses these terms interchangeably.

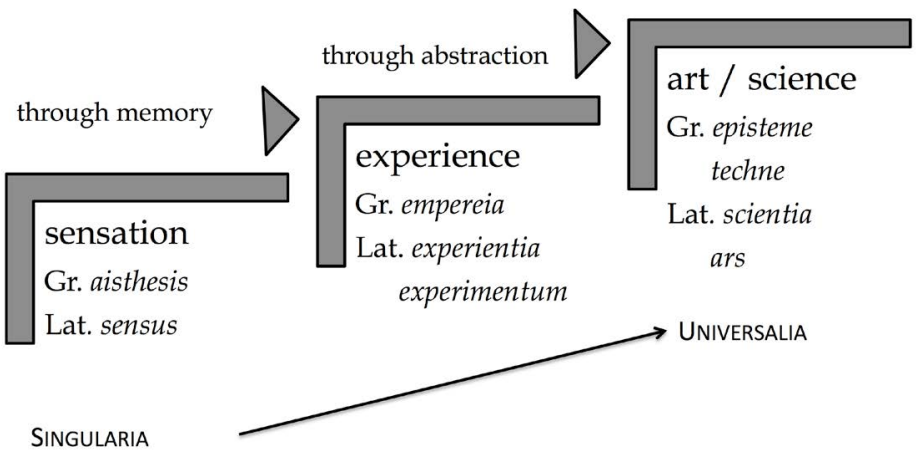

Both terms-experimentum and experientia-stem from the verb experiri, and in classical Latin both nouns have nearly the same double meaning. ${ }^{13}$ Both cover "experience" (in the sense of Latin peritia, usus, notitia) as well as "experiment" (in the sense of Latin probatio, temptatio, periculum), experimentum sometimes tending a bit more towards the realm of "peril" (periculum). In the former sense both can signify both the act of "experiencing something" and (in a passive sense) that which has been experienced. In mediaeval Latin the synonymous use of both terms (with the aforementioned tendencies) generally continued. ${ }^{14}$ In translating Aristotle's empereia mediaeval translators use both terms interchangeably. In describing the contrast between "experience" and "inexperience," James of Venice, for example, uses experimentum but inexperientia for the

10 On the distinction between musicus and cantor, see Bower $(2002,152,163)$.

11 On the following, see Herzberg (2011, chap. 5).

12 Aristotle, Analytica Posteriora 2.19, see, for example, Aristoteles (2011, 197-99).

13 See the articles "experimentum" and "experientia" in Thesaurus Linguae Latinae (1931-53, V 2:1654-6o, $1651-53)$.

14 See the articles "experimentum" and "experientia" in Mittellateinisches Wörterbuch bis zum ausgehenden 13. Jahrhundert (1956-, 3:1637, 1638-39); Sarnowsky (2012, 47-59). 
contrary, since inexperimentum did not exist. It took some time until a precise distinction was explicitly drawn.

In the seventeenth century Francis Bacon explicitly distinguished the two terms: "Restat experientia mera: quae, si occurrat, casus; si quaesita sit, experimentum nominatur" (Novum organum 1.82, Bacon [1620] 1874, 274; What remains is mere experience, which is called casus when it is an accidental occurrence and experimentum when it was sought for). Francis Bacon, however, obviously elucidated something that had been implied in the use of the terms since at least the thirteenth century. Thomas Aquinas seems to use the two terms in something close to Bacon's sense here and there (Lutz-Bachmann 2007, 157); and in the thirteenth-century scientia experimentalis of Roger Bacon, experientia is the perception of singulars in the Aristotelian sense and experimentum is a scientific procedure based on experientia, including also directed "experimental" operations using laboratories and instruments (Hackett 1998; 2013, 4.2; Mensching 2009, 52-58). However, Bacon, a Franciscan friar, differed from later writers on experimental sciences by embedding his experiments and his concept of empiricism in a larger metaphysical context. According to him, experiments involve an element of immediacy, allowing the human intellect to transcend the boundaries of scientific discourse through divine inspiration. Bacon describes experience and experiment as those moments when divine inspiration intervenes and interrupts rational argumentation through a kind of epiphany. In more recent terms, experience and experiment, as described in the thirteenth-century scientia experimentalis, enable "the non-identical" (das Nichtidentische), as Adorno would say, to break through the boundaries of self-referential scientific systems. ${ }^{15} \mathrm{~A}$ person with a lot of experimentum and experientia was called an expertus; and it is crucial to keep in mind (although this point can only be mentioned here in passing) that mediaeval authors speaking about "experience" sometimes referred to something experienced not by themselves but rather by an experienced authority, by an expertus they had read or heard (Jüttner 1989). Hence we have to be careful not to rashly impute a modern concept of subjective, individual "experience" to mediaeval authors speaking of experimentum and experientia. Generally, the Neoplatonic tradition was characterised by scepticism towards sensual perception; in his widely distributed Didascalicon (2.17), Hugh of Saint Victor wrote that "Fallax experimentum est"- "experience is fallacious" (quoted in Haas 2007, 76). There are, to be sure, some famous fourteenth-century examples of something closer to a "modern" concept of "subjective" experience that was then set in opposition to experiences handed down by authorities; Petrarch, for example, in his De vita solitaria, explicitly prefers personal experience (experientia) over booklore (auctoritates, exempla), actually drawing on a tradition of monastic contemplative literature that distinguished itself from scholastic theological discourse (Petrarca 1990, 176-85). ${ }^{16}$

15 This corresponds with Lydia Goehr's (2008b) description of "the experimental."

16 Of course Petrarch was well aware of the complex relationship between pre-existing experientia and the potentially endless, ever-searching personal experience: the former not only enriches and stimulates the latter, it enables those who explore their own souls to advance into otherwise submerged realms in the first place (Stierle 2003, 182, 284). 
In the context of Aristotelian epistemology and its mediaeval reception, then, experientia and experimentum signify implicit knowledge gained by continuous sensual perception, an embodied remembrance of actions. It is, however, only through abstraction and reflection that experientia and experimentum become ars and scientia. The implicit, practical knowledge of the expertus has to become explicit knowledge combined with theoretical or methodological reflection to become an ars or scientia in Aristotle's sense. Experimentum and experientia denote "knowing that"; ars and scientia include the additional "knowing why."

Clearly, ars and scientia cannot simply be translated with our modern terms "art" and "science." This is not the place to discuss the complex history of these terms in the Middle Ages and afterward. Suffice it to say that the difference between ars and scientia, at least in the original Aristotelian sense, is defined quite simply: scientia is knowledge that works within closed systems and their given timeless principles, while ars deals with those things that are contingent, that can be different, that are made. ${ }^{17}$ Ars in the Aristotelian sense is described as a "habitus quidam cum racione factivus," an "attitude concerned with making that involves true reasoning" (Aristoteles 1973, 481). ${ }^{18}$ Apart from the much-vaunted concept of the mediaeval ars musica as a quadrivial art without any noticeable link to actual sounding music — an art, hence, that basically works like a scientia and was referred to as such ${ }^{19}$ - the Aristotelian notion of ars as a conscious skill aiming at acts and works (or acts as works) was familiar throughout the Middle Ages and was also applied to music. Indeed, Isidore of Seville defined musica as a "skill" (peritia; note the etymological relationship to experientia and experimentum) dealing with "songs and chants." ${ }^{20}$ To mention another example, Robert Kilwardby, in the thirteenth century and drawing on Aristotelian tradition, distinguished between "operative," "productive," and "speculative" arts (ars operativa, factiva, and speculativa) and explicitly assigned the art of kithara playing (ars citharizandi) and the art of singing (ars cantandi) to the "operative" arts, since (in contrast to shipbuilding, for example) these arts do not produce enduring works ("non relinquunt opus manens") (Haas 1982, $\left.375^{-81} ; 2007,13^{2-}{ }^{6} 6\right) .{ }^{21}$ What kind of opera they actually produce is another topic too wide to be considered here (Haas 2007, 123-56).

After this digression on experimentum and Aristotelian epistemology, a little anecdote will serve to bring us back to Johannes de Muris, as it accurately illustrates both Muris's acquaintance with Aristotle and the far-ranging interchangeability of the terms experimentum and experientia. This anecdote in fact is probably the most famous myth of Western music: Pythagoras, upon expe-

17 See Ethica Nichomachea 4.3. This distinction was known throughout the Middle Ages (Haas 2007, 123-32, especially footnote 221)

18 A closer examination of this description in given in Haas $(1984,117)$.

19 Franchinus Gaffurius, in his gloss on Muris's prologue, speaks of "seven liberal sciences" instead of "seven liberal arts" and adds that the trivium includes no scientiae proper since only the four quadrivial sciences (including musica) are scientiae (“... sunt proprie et vere scientiae”; Gaffurius, Glossemata super nonnullis partibus primae partis theoricae musicae Ioannis de Muris, quoted in Gallo 1974, 53).

20 Isidore, Etymologiarum sive originum libri $X_{3} .15,1.2$, quoted in $\operatorname{Bower}(2002,148)$.

21 Another point of reference is the beginning of the sixth book of Aristotle's Metaphysica, which distinguishes between scientia activa, factiva, and theorica in Moerbeke's translation (Aristoteles 1995) and scientia practica, poetica and theorica in the translatio media (Aristoteles 1976). 
riencing the sound of hammers by chance, began experimenting with other instruments to corroborate a theory of sounding numbers, a theory that would have immense consequences. Muris, to be sure, mentions all the key terms of Aristotelian epistemology: "Ex quibus experimentis ad memoriam concurrentibus accepit unum universale, quod sibi fuit principium artis et scientiae" (Notitia 1.3, Muris 1972, 57, my italics). ${ }^{22}$ He probably knew this anecdote from Boethius's De institutione musica (1.11), but interestingly he substitutes for Boethius's terms examinatio (describing Pythagoras's act of inquiry) and experientia (describing the result) a term not used by Boethius in this context: experimentis.

NON AUTEM [EXPERTI] SCIENTIA FACIUNT, QUAE FACIUNT UT IGNIS EXURIT. "The eXperti do not do scientia, because they behave like burning fire." This metaphor, taken literally from Aristotle, illustrates the status of the experienced: fire burns without knowing it or why it burns. Like the fire, those who have only experience, with no theoretical reasoning, possess highly valuable knowledge; but since this remains implicit, they are not yet doing scientia in the Aristotelian sense.

SED INTELLEGERE ET SCIRE CIRCA UNAMQUAMQUE ARTEM MAGIS ARTE QUAM EXPERIMENTO ESSE ARBITRAMUR. "We think that knowledge and insight belong to ars rather than to experimentum." Muris, still quoting backwards from Aristotle, explicates Aristotelian epistemology again (cf. figure 1). Experimentum-that is, experience-needs to be combined with more abstract insight to become an ars. Taking this and the preceding sentence together, one necessarily gains the impression that Muris uses the terms ars and scientia interchangeably. Although in a strictly Aristotelian sense they denote very different things, Muris here probably takes them together, since in opposition to mere experience, both ars and scientia imply theoretical reflection (Haas 1982, 395-97).

IDEOQUE ARTIFICES EXPERTIS SAPIENTIORES ESSE OPINAMUR. "Therefore we assume that artists are wiser than the [merely] experienced." This is a simple syllogism. First premise: artists have more knowledge than experti (men of mere experience). Second premise: knowledge is a part of wisdom. Conclusion: artists are closer to wisdom than those who only have experience.

ET OB HOC ARTEM MAGIS EXPERIMENTO SCIENTIAM ESSE EXISTIMAMUS. "That is why we think that ars, rather than experimentum, is scientia." The same conclusion in other words: since ars implies abstract reasoning, it is closer to scientia than mere experience.

POSSUNT ENIM HII, HII AUTEM DOCERE NON POSSUNT. "They [the artists/theorici] can teach, whereas they [the experti/pratici, the merely experienced] cannot." Here Muris returns conclusively to his first sentence, which he set out to prove and which he considers proven here. But since Muris is continuously quoting both backwards and forwards from Aristotle, this conclusion seems completely unmotivated here. There is obviously a missing premise for this conclusion. We have learned that the theorici have abstract knowledge, and here we have the conclusion that only the theorici are able to teach. Muris forgot to mention the premise: it is necessary to have a more abstract knowledge of principles and causes to be able to teach, an Aristotelian concept that understands "teaching"

22 On this sentence and its (inadvertent?) reversion of the Aristotelian terms, see Hentschel (200o, 87-89). 
(docere in Latin, didaktein in Greek) as a scientific or academic lecture rather than practical instruction.

So far, so good. Until here, Muris's argument, apart from his rather generous use of terminology, seems quite straightforward and clear. Theoretical knowledge is preferred to mere experience, theory is more highly regarded than practice. This is a commonplace that pervades mediaeval musical literature, and it cannot be considered an exciting surprise to see a mediaeval theorist quoting Aristotle as an authority in support of theory. But it is just at this point that Muris's argumentation takes a truly dialectical turn and swerves back in the diametrically opposed direction, since now experience seems to be preferred to theoretical knowledge.

QUONIAM TAMEN ARS EST UNIVERSALIUM, EXPERIMENTUM VERO SINGULARIUM, UNIVERSALIA PRAESUPPONUNT SINGULARIA, IGITUR ARS EXPERIENTIAM PRAESUPPONIT. "But because experimentum is the knowledge of particulars and ars that of universals, and because universals presuppose particulars, ars presupposes experientiam." First of all, this sentence proves that Muris uses the terms experimentum and experientia interchangeably, since he substitutes the former for the latter in the second half of this sentence..$^{23}$ The first half of this sentence is a quotation from Aristotle, restating the by now familiar idea that experimentum or experientia is the knowledge of particulars, while ars is the refinement of these to more universal principles through reflection. The second half of the sentence, then, is Muris's own contribution, adding another premise and a conclusion. And this new premise ("universals presuppose particulars") is a quite distinct statement in the so-called Universalienstreit, the "problem of universals"- that is, the longterm mediaeval discussion of the question whether universal ideas really exist and precede the particular or the other way round (Mensching 1992). Muris here casts his vote for the priority of the particulars, in relation to which the universal concepts are abstractions. His scholastic syllogism works in this manner: if (first) experientia/experimentum deals with the particular and ars with the general, and if (second) the particular precedes the general, then we can conclude that experientia/experimentum precedes ars.

EXPERIENTIA ${ }^{24}$ QUIDEM FECIT ARTEM ET EXPERTOS MAGIS PROFICERE VIDEMUS RATIONEM SINE EXPERIENTIA 25 HABENTIBUS. "Experientia produced ars and we rather observe those with experientia being more successful than those who have a theoretical understanding without experientia." This is an original Aristotelian thought: an ideal artist combines experience with reason, contemplative life is preferred to practical life, theoretical knowledge generally to practical knowledge. But, for an artist, experience without reason is more helpful than reason without experience. In the widespread Auctoritates Aristotelis, a florilegium of Aristotelian sentences, this idea was paraphrased in the following way: "While science

23 The scribe of one of the ten extant manuscript copies of Notitia indeed tried to harmonise terminology and replaced experientiam in the second part of the sentence with experimentum (Muris 1972, 48, critical apparatus for line 6).

24 The translation by James of Venice actually reads "experimentum quidem enim artem fecit" (Metaphysica 1.1, Aristoteles 1970, 5).

25 On the problematic manuscript transmission of this sentence, see Muris $(1972,107-8)$. 
without experience is of little or no use, experience without science is of much use" (quoted in Haas 1982, 375; Sicut scientia sine usu parum vel nihil prodest, sic usus sine scientia multum).

IGITUR NECESSARIUM EST IN UNAQUAQUE ARTE HABERE PRIMO [SCIENTIAM] THEORICAM, PRACTICAM CONVENIENTER [alternative readings: PRACTICAM CONSEQUENTER and PRACTICAE CONIUNCTAM], UT ILLUD, QUOD SCITUM EST IN UNIVERSALI, AD SINGULARE VALEAT APPLICARI. SED CUM OMNIS ARS EX EXPERIMENTIS DEPENDEAT, OPORTET UNUMQUEMQUE ARTIFICEM PRIMO CIRCA ARTIS EXPERIENTIAM LABORARE. "Therefore it is necessary in every ars to have in the first place theoretical knowledge in a manner appropriate to practical knowledge, so that knowledge of universals can be applied to the particular. But since every ars depends on experiences, every artifex should first labour in the field of artistic experience." This seems contradictory. Should an "artist" have an appropriate theory first and apply it thereafter to practice, or should he first labour to gain artistic experiences and only later speculate? Aristotle and Muris would say both at the same time. We now reach a point where we can see that Muris's epistemology—that is, Aristotle's epistemology—is more complex than a simple one-way street ascending from sensation and experiment to general knowledge. Rather, it describes experience and theory, knowledge of particulars and knowledge of universals, in a dialectic entanglement, in a hermeneutic circle. Crude binary oppositions- "experience" versus "abstract reasoning," "empiricism" versus "rationalism," "inductive bottom-up method" versus "deductive top-down method"- - have to be refined.

We have already seen how Aristotle described the way upwards from sensation through experience to knowledge, from particulars to universals (figure 1). In his Physica, however, Aristotle says something different: that we have to start from the universal and proceed to the particular. ${ }^{26}$ An explanation for this might be found in the famous first sentence of the Analytica posteriora, which was very familiar to Muris, who quoted it literally in his Musica speculativa: "Every knowledge acquisition depends on prior knowledge" (Falkenroth 1992, 90-91; Omnem doctrinam et omnem disciplinam ex praeexistente cognitione fieri). ${ }^{27}$ In other words, we have to know something to learn something, we have to know something universal to experience the particular. Experience presupposes the knowledge of principles, at least as tacit or implicit knowledge. To be able to collect and compare a series of experiences or experiments, we have to be able to recognise them as experiences of the same thing. Otherwise they would remain an unsorted array of sensations. If we have the experience that medicine A helped to cure Socrates and Kallias and several other people from disease $\mathrm{B}$, we can conclude (tentatively) the general knowledge that medicine $\mathrm{A}$ helps to cure all human beings from disease B. But we have to know in advance that the administered medicine was exactly the same every time, that the indications we saw were symptomatic of exactly the same disease, that all patients were exemplars of the same species, and so on (Herzberg 2011, 183).

26 "Unde ex universalibus in singularia oportet provenire" (Aristoteles 1990, 8).

27 Muris probably quoted from the Florilegium Aristoteles (Hentschel 2000, 239). 
Returning to our subject, according to Aristotle there is, as we have seen, no theory without prior experience; but Aristotle also writes that there is also no experience without prior concepts. To process data we require a conceptual component. For Aristotle, perception is already a complex discriminating activity, not a "blind" provider of data (Herzberg 2011, 218-20; see also Detel 2011; Schmitt 2003). This idea, the notion that the external world does not reveal itself directly to us but is always mediated by prior concepts, this deconstruction of what Wilfrid Sellars called the "myth of the given," is, of course, not exciting news for a twenty-first-century reader. But it seems worthwhile in this context to reflect on how old this discussion, in all its dialectical complexity, actually is: in popular accounts, Aristotle is frequently depicted either as the empiricist who transferred Plato's ideas from heaven down to earth or-the very opposite-as the master of scholastic rationalism, deducing all knowledge from given principles by a rigid logic. Central passages in Aristotle are "Janusfaced," as Jonathan Barnes (1975, 248-49) has put it, "looking in one direction towards empiricism, and in the other towards rationalism"; consequently it is "a classic problem in Aristotelian scholarship to explain or reconcile these two apparently opposing aspects of Aristotle's thought." In the Middle Ages Aristotle could be cited as an authority both by those who claimed the priority of universals and theory and by those who claimed the priority of particulars and empiricism (Detel 2011, lxii-lxviii). Johannes de Muris, however, did not reduce Aristotle to one of these two aspects. He did not try to dissolve the hermeneutic circle of theoretical knowledge and experience, as the prologue to his Notitia artis musicae imposingly shows.

But how did Johannes de Muris reconcile theory and experiment in his own writings, then? In his musica theorica, Muris, as is well known, treats musica as a scientia media in Thomas Aquinas's sense, participating both in physics and in mathematics, having both a material object (sound) and a formal object (numeric ratios) (Haas 1974; Hentschel 2000, 131-46). While the astronomer Muris explicitly described some of his own observations and experiments, the music theorist Muris only hints at the role of experimentation for musica theorica, without further developing it (Hentschel 1994-2007b, 1103-4). Consequently, in the following, I will focus on the role of experimentum/experientia in his musica practica.

In his musica practica Muris neither depicts "practice" as a collection of experiments or experiences nor does he unfold and deduce theories without regard for experience. In Muris's Notitia the chapters on musica theorica actually come first; however, the part on musica practica is twice the length. Muris on the one hand carefully (and now and then reluctantly) adapts traditional theories to recent developments in music that he obviously experienced; on the other hand he suggests new directions for musical practice inspired by theoretical speculation. And Muris is very clear about this mutual relationship between experience and theory: "Omne enim, quod profertur, debet figurari, et quod figuratur, licet de difficili, debet proferri"- "Everything that is sung, has to be writable, and everything that is written, even if difficult, has to be singable" (Notitia 2.10, Muris 1972, 96, see figure 2 for this passage as given in a man- 
uscript from Ghent).$^{28}$ The word proferre (bring out, utter), which was known as a term to distinguish the act of singing from the act of writing, ${ }^{29}$ obviously connects the discussion to actual sounding music. In a book and in a time for which notation was the central theoretical issue, this means that everything discovered by experience and through experiment can enhance our theories and that everything discovered by theory and through thought experiment can enhance musical practice.

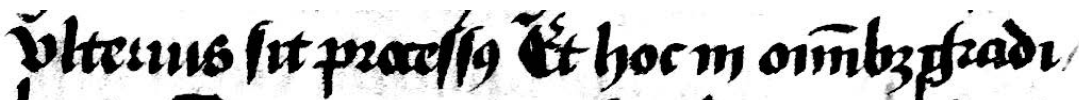

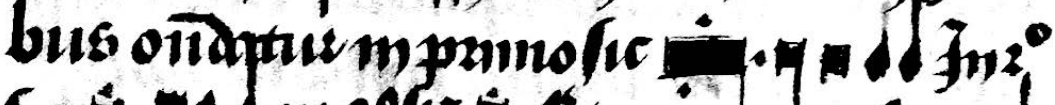

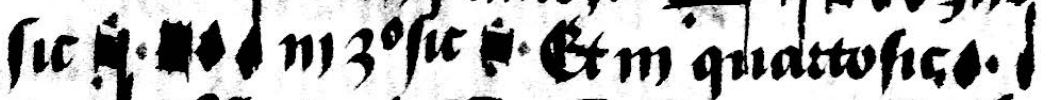

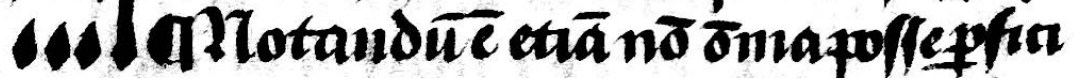

Fig. 2.

It is easy to find examples for theory following new practices. Muris famously introduced rules of imperfection and later also of binary mensuration, deviating from traditional theory in that regard. $3^{\circ} \mathrm{A}$ perfect longa in his system could be imperfected not only by a brevis but also by a semibrevis, through the so-called imperfectio ad partem. This could be expressed by conventional note shapes. However, for the opposite, perfectio ad partem, new signs were useful: Muris suggested a dot on top, below, or to the left of a note head as a notational device for this new practice, suggesting perfection ad totum, ad partem, ad partem remotiorem, and ad partem remotissimam (see figure 3 ).

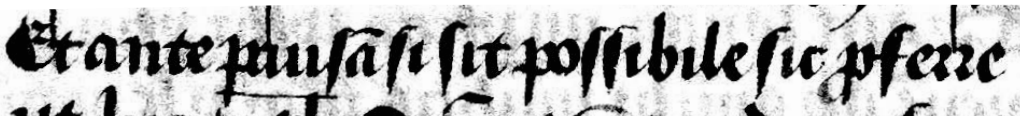

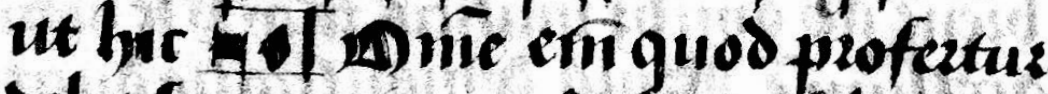

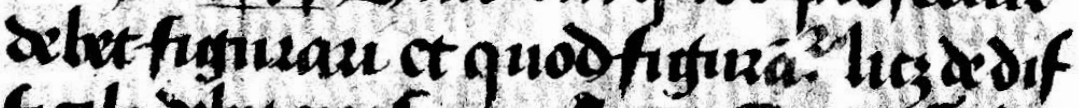

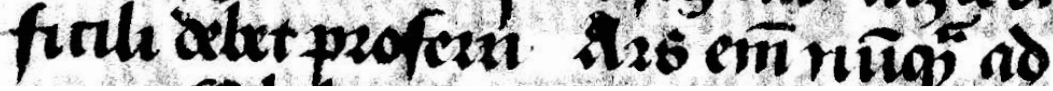

Fig. 3.

28 Elsewhere Muris says the same in other words: "Quoniam sicut contingit ex ore proferre, sic possibile est notare, dum vox sit integra sive recta” (Notitia 2.7 , Muris 1972, 84). The addition "dum vox sit integra sive recta" (if the voice is intact or correct) again implies a kind of argumentative circle: every experience is writable if it happens in some kind of conceptual framework.

29 Prosdocimus de Beldemandis, a century later, however, explicitly distinguishes contrapunctus vocalis from contrapunctus scriptus: the first is "sung" (vocalis qui profertur), the second written (scriptus qui scribitur) (Prosdocimus 1984, 32).

30 That theory followed practice here was clearly recognised by Muris's famous critic Jacobus Leodiensis, who criticised the "treatises modelled on modern song" (Jacobus 1955-73, 7.6; modernus cantandi modus ... tractatusque super hunc confecti). 
In the scholarly literature there exists a certain confusion regarding whether Johannes de Muris actually introduced, acknowledged, generally allowed, or even appreciated imperfection and/or imperfect mensuration in his Notitia or whether this only occurs in the later Libellus, of which he probably was not the direct author. In a certain sense this confusion fits Muris's discussion of these matters perfectly. In fact, Muris is clear about imperfection, which is indeed introduced and appreciated on all levels for the first time in his Notitia (see above). Imperfection, however, presupposes perfect mensuration, and whether he actually tolerated binary mensuration on all levels, as has been argued, is a much more complex question. Muris's argument is rather vague and partly contradictory; to put it more positively, after announcing explicitly that he will discuss precisely those matters on which "practitioners think in different ways" (Notitia 2.1, Muris 1972, 65), ${ }^{31}$ he never resolves the most urgent issue of a contemporary quarrel. He seems to assume some arguments on both sides without suggesting a clear compromise. Muris, in brief, sympathises with the practical musicians he openly admired but tries not to offend respected theoretical authorities either. He acknowledges the existence of all different mensurations and certainly appreciates them, but he also refers positively to those theoretical principles that stand precisely against those developments and appreciates them as well: "In arte imperfectum non convenit reperiri"- "It is not suitable to search for the imperfect in art" (ibid., 66). But elsewhere he undermines the prevalence of ternary perfection with a strong and bold theoretical argument: "Tempus is twofold, one major, one minor, the major one having a longer movement, the minor one a shorter, both can be regarded in the same way" (ibid., 65)..$^{32}$ With this Muris declares that there is neither a substantial nor qualitative but rather a quantitative difference between imperfect and perfect note values (see Haas 1974; Tanay 1999, 82-84). He even describes the "Petronian" notion of dividing a brevis into any number of equal parts (including not only 2 and 4 , but also 5,7 , and 9) and then explicitly praises the experienced musician capable of doing this: "Laudable is the experienced musician who sings over the same tempus by dividing it now in two, then in three and in all other numbers of parts" (Notitia 2.13, Muris 1972, 105).33

What shall we do, then, with the obvious contradiction between acknowledging the unrestricted division of time on the one hand and praising the perfect (ternary) division at the expense of the unworthy binary on the other? To come back to the social type mentioned in the beginning, one could say that Muris, as an avowed musical amateur, had probably encountered musica theorica much later than musical practice and originally only in passing during his academic studies. His admiration for music practitioners went together

31 "De ipsa diversi diversimode sentiant practicantes."

32 "Temporis aliud maius aliud minus: maius quod motum prolixiorem, minus quod breviorem ... Haec autem specie non differunt, nam maius et minus speciem non variant. Inde est, quod unum modum retinent cognoscendi, nec in hiis scientia variatur."

33 "Quod autem tempus possit dividi in quotlibet partes aequales, patet ex hiis.... Fiet igitur cantus ex 2 , $3,4,5,6,7,8$, 9 semibrevibus aequalibus eiusdem figurae.... Laudabilis autem esset musicus et peritus, qui super idem tempus aequale ipsum dividendo nunc per duas, nunc per tres et ceteras partes integre discantaret." 
with a need for being recognised as a music theorist in his academic environment, a need evidenced in large parts of the Notitia. This double bind may be responsible for many of the apparent contradictions. A telling example is his first attempt to deal with the introduction of imperfect values and mensuration by the moderni. Having given the aforementioned explanation that from a physical point of view a unit of time can be divided in any number of parts confined by a minimum and a maximum, he simply reports that his "predecessors" (priores) were of the "opinion" (opiniantes) that musical time should only be divided by three, since perfection is only found in three. Muris then gives an impressive list of things that come in three and that prove the dignity of the ternary (the Holy Trinity, the three terms of a syllogism, the three ways of the intellect, etc.), introducing all of them, however, as "conjectures" (coniecturis). Having said this, he adds that unity is well known to be perfect, too (a central idea of Neoplatonism), and comes back to his physical idea of the multiple divisibility of a unit. In other words, he acknowledges the theoretical tradition of his predecessors as a contingent but respectable position but opens up ways to theorise the modern music he obviously appreciated. And Muris reaped the reward for this attitude. His most famous critic, Jacobus, quotes from Muris's writings, at times with approval, at times with rejection. And it is more than only an irony of fate that Jacobus's book was for a long time taken to be a work by Muris himself (Gallo 1984, 278-83; Hentschel 1994-2007a). If, on one hand, the aforementioned example of imperfection enhances the theory of notation to accommodate a new practice, on the other hand, new and unheard possibilities for practice can be found through speculation and conclusion. Premise 1: a longa can be imperfected by a semibrevis. Premise 2 : every note value can be substituted by an equivalent rest. Conclusion: the rhythm ${ }^{\circ}-p$ - (see reproduction in figure 2), although non-existent in musical practice, is thinkable and writeable, and for this reason it also should be singable. In this way, thought experiments serve as catalysts for new experiences. This reciprocal relationship between theoretical speculation and practice was one of the points of attack in Jacobus Leodiensis's Speculum musicae. Jacobus did not argue against an empirical or sensuous approach per se (see Hentschel 2011), but he criticised the theorici for descending to matters of practice, exclaiming "O would speculation not descend to practice" (Jacobus 1955-73, 7:50),34 and likewise the pratici for presuming to do speculative theory, saying that "they reduce their ars, which is basically practice, to subtlety and speculation, and by doing so confuse practice with speculation" (ibid., 7:25).35 Do they not, then, "convert the practice of discant into speculation?" (ibid., 7:14). $3^{6}$ Jacobus Leodiensis clearly was not at ease with the entanglement of theory and practice, of experimentum and speculation, that he sensed in books like the Notitia; rather, he mistrusted it (see Gallo 1984, 278-82; Harne 2010). And Johannes de Muris clearly felt the direction of this new line of inquiry: "There are many other novelties hiding in music, that

34 "Utinam hec speculatio ad praxim non descendisset."

35 "Artem enim, que vere et principaliter practica est, ad subtilitatem quandam et speculationem reducunt sicque praxim et speculationem inter se confundunt."

36 "Nonne tales finem mutant, discantuum praxim in speculatione convertuunt?" 
will without doubt become visible to posterity" (Notitia 2.7, Muris 1972, 84).37 "Nobody may claim that we have reached a definite state and inevitable end of music, for opinions and sciences are racing in revolutions that return cyclically" (Notitia 2.14, Muris 1972, 106-107). $3^{8}$

Having contemplated the term experimentum in an Aristotelian context, one further context will be discussed briefly here. In a widely distributed treatise, probably misattributed to Muris, edited by Coussemaker as part of a larger Ars contrapuncti, and referred to today usually as Cum notum sit, we read: "Whoever wants to sing [improvise] counterpoint over plainchant needs to have much ready to hand to utter his song pleasingly" ([Pseudo-]Johannes de Muris 1869, 3:60).39 The idea of "having much ready to hand" (multa pre manibus habere ad hoc) obviously refers to a well-known idea in classical rhetoric: Quintilian, describing "the weapons that the orator should have ready at hand" (haec arma habere ad manum), mentions that "the orator should be equipped with a rich store of examples" (Institutio oratoria 12.5.4, Quintilianus 1972, 2:726, 724). Speaking about improvisation, Quintilian explicitly distinguishes between elements to be learned through theory (ex arte) and elements to be learned by studying, remembering, and embodying the huge repertory of examples (ex studio) (Institutio oratoria 10.10, Quintilianus 1972, 2:530). Stating that "in most subjects precepts are less valuable than experience," Quintilian in fact uses the term experimentum: "In omnibus fere minus valent praecepta quam experimenta" (Institutio oratoria 2.5, Quintilianus 1972, 1:196). It is by now well known that counterpoint pedagogy in the Middle Ages and the Renaissance, in some places far into the eighteenth century, largely consisted of contrapunto alla mente, "mental counterpoint"- that is, of unwritten, sung and performed polyphony, cantare super librum (singing polyphony from the monophonic chant books). This kind of "performance-composition" (to borrow a term Leo Treitler $[1974,353]$ has introduced in a different context) was omnipresent in the everyday life of a musician. The instruction books teaching this kind of counterpoint blur the boundaries of what we today would separate as composition, improvisation, diminution, ornamentation, and performance; and the ability to improvise and to produce music in real time is of course based on a mental collection of recurring schemata and procedures the musician has at his or her hands, a collection not necessarily generated by theory but necessarily acquired through experiment and experience. Counterpoint instruction in the fourteenth and fifteenth centuries, as far as we can judge from the extant sources, mostly followed the same procedure. First the students learned to make a simple counterpoint, note against note, punctus contra punctum, later

37 "Sunt autem multae aliae novitates in musica latentes, quae posteris bene dubitantibus apparebunt."

$3^{8}$ "... nemo tamen dicat nos statum musicae et finem eius immutabilem tetigisse. Currunt enim opiniones et scientiae revolutiones ad circulum revertentes."

39 "Qui supra planam musicam voluerit discantare, eum oportet multa pre manibus habere ad hoc ut suum cantum possit placibiliter proferre." On this treatise see Michels 1970, 40-42; Sachs 1974, 179-84. 
referred to as contrapunctus stricte sensu (counterpoint in the strict sense). They then learned to use this simple counterpoint as a framework for a more florid counterpoint, counterpoint in the broader sense, with smaller note values and dissonances, referred to in the fourteenth century frequently as discantus. While counterpoint in the strict sense was taught through a system of rules (ex arte in Quintilian's sense), florid or diminished counterpoint was mostly demonstrated only by example, experiment, and experience (ex studio or ex experimentis). The apprentice in fourteenth-century counterpoint became an expertus by going through a series of examples the student had memorised and transformed into experience. The huge field of florid counterpoint, of dissonance treatment, of three- and four-part-writing, so important for practice, was not taught through rules, but through experimentum, through experiment and experience, which opens up, by the way, one of the most fascinating qualities of this music: later counterpoint is regulated by rules in a much narrower sense and to a higher degree (Memelsdorff 2008).

To conclude and to come back to the context suggested by this volume, it might seem too bold a thought experiment to finish this essay by transferring the sentence "omnis ars ex experimentis dependeat" to artistic experimentation and practice as research. Since, as has been shown so far, the mediaeval terms experimentum and ars are far from interchangeable with today's terms "experiment" and "art" (and the same pertains to scientia and "science," experientia and "experience"), ${ }^{40}$ such a transference would certainly seem to be a shortcut from concepts to phenomena, which is exactly what Begriffsgeschichte should avoid (Koselleck 1979, 121). On the other hand it is precisely the disruptions and shifts in the history of a concept that make the divergence between concept and matter perceptible, that show the contingency of today's concepts, that enable diagnosis and anamnesis of current situations, and that open up glimpses of those ideas of the past that have been repressed, glimpses of that which was not realised or lost. Hence such an attempt might prove illuminative in our context for those sharing professions that frequently feel themselves to be "nicht Kunst, nicht Wissenschaft" (Holtmeier 1997), neither "art" (in the modern sense of "fine art") nor "science" (in the modern narrow but paradigmatic sense of "natural sciences"), nor even an ars in the mediaeval sense of the academic liberal ars musica (a speculative science, actually), but maybe something close to an ars in the other mediaeval and more Aristotelian sense of "habitus quidam cum racione factivus," an attitude concerned with making (and with things that are made) that also involves reasoning. Or (to stress the aspect of experimentum), an attitude concerned with embodied remembrances

40 Max Haas got to the heart of this by suggesting "dass 'Kunst' mit ars so wenig zu tun hat, dass man mit der Annahme besser fährt, ars und 'Kunst' hätten miteinander überhaupt nichts zu tun” (Haas 2007, 22; the term "art" has so little to do with ars that it is more productive to assume no relation between the two at all). On the difficulty modern epistemology might have with the Aristotelian concept of "experience" see Lutz-Brachmann (2007, 160-62). 
of actions and sensations that also involves theoretical, methodological, and historical reflection. Furthermore, the different understandings of experimentum as seen in the context of post-Aristotelian mediaeval discourse might be just another stimulus to clear up our own understandings and usages of the term "experiment" in the arts, a term that has for a long time become so vague that some wanted to discard it completely (Saxer 2007). If our historically informed critique of the terms ars and experimentum would then be able to subvert the modern connotations of "art" and "experiment" (or even turn them into the complete opposite), such a critique would meet Lydia Goehr's (2008a, $\mathrm{x})$ observation that "concepts that promise so much good may, by subtle and not so subtle alterations in their use, end up abetting enormous harm."

Let us try, then, to transfer Aristotle's and Muris's concepts to more recent discussions, if only-as Wolfgang Welsch (2012, 388-89) has suggested-to assume their complex style of arguing. To put the question even more provocatively: What would Aristotle and Muris have to say to those interested in "artistic experimentation" and "art as research" today, to us?

First, they might appeal to the scientist in us. They would advise us to take our theories from experience or to test traditional theories by application of experience - that is, by testing whether the languages of science remain translatable into the languages of experience. They would also remind the scientist in us that there is a kind of highly valuable knowledge that is not a scientia in the strict sense; they would remind us that sometimes, as Aristotle puts it, it is enough to know "that" (quia) without knowing "why" (propter quid), so that in art, generally, those who only have experience are more successful than those who only have theory. Having said this, Aristotle and Muris then probably would appeal to the experimenter, to the artist, to the sensitive person in us. And here they would caution us against a naive empiricism. There is no such thing as "just looking at how things really are." There is, regarding music analysis for example, no such thing as speaking about the music itself without theoretical mediation; there is, regarding performance practice, no such thing as "letting the music speak for itself," as Taruskin ([1981] 1995) has put it. Aristotle and Muris would insist that no experiment, no experience starts from tabula rasa, from a blank slate, but rather either from an explicit theory to be proven or from an implicit, tacit, embodied knowledge. To explicate this very kind of knowledge is to transform experimentum into an ars.

Looking back to the beginning, we have finally reached a point where we can see that the sentence from which we departed ("omnis ars ex experimentis dependeat") might mean something quite different from what we would like to read into it. In fact, it might even mean the complete opposite. Of course, from a modernist perspective one would love to detect a mediaeval anticipation of modernism's conviction that every art depends on the experimental, in the sense of Adorno's ([1962] 1992, 322) famous "make things in ignorance of what they are." ${ }^{11}$ However, the term experimentum, as we have seen, could have

41 "Die Gestalt aller künstlerischen Utopie heute ist: Dinge machen, von den wir nicht wissen, was sie sind." 
several quite different meanings in the fourteenth century, and it is no coincidence that these different, seemingly contradictory meanings are embraced under the same term. In common parlance of the late mediaeval reception of Aristotle, the term experimentum is used more or less interchangeably with experientia (experience), as it is also in Johannes de Muris's writings, as we have seen in his Notitia artis musicae of 1321 . Following Aristotelian epistemology, experimentum and experientia denote knowledge based on experience and sensual perception that complements and at least in a certain sense precedes theoretical knowledge, which by definition is based on deduction and syllogism. The sentence "omnis ars ex experimentis dependeat" then simply means "all artistic knowledge starts with experience" in the sense of "all knowledge starts with sensual perception." In this context, however, experimentum and experientia could be understood not only in the sense of "experiencing something," but also in the sense of "having experience" or "being experienced"-that is, being trained, being exercised, having an embodied remembrance of actions, like musicians capable of producing polyphonic music, be it "improvising" or on paper. Experimentum makes an expertus, experimentum creates the authorities much sought for in the discipline of polyphonic music, which lacked true auctoritates. The fact that practitioners and their works became a kind of auctoritas for musica practica is one of the most remarkable developments of the late thirteenth and fourteenth century, Johannes de Muris being a prominent example (Leitmeir 2013).

Today, of course, the terms "experiment," "experimental," "to experience something," "to be experienced," "to be an expert," or "to be trained" have completely different connotations. The observation that they all partake of the same family of Latin words, however, opens up the possibility of regarding them as different sides of the same coin. Experimentum in the sense of artistic training, for example, is an unfinished series of single experiences; experimentum in the sense of experiencing something is not a naive or spontaneous perception. "Experience" is a term extremely difficult to grasp, because it refuses theory by definition, on the one hand, and on the other is inescapably related to theory, as we have seen (Kessler, Schöpf, and Wild 1973, 385). Experience can escape the stranglehold of theory only by turning theory against itself, which takes us back to the title of this essay for a last time. If art and knowledge depend on experimentum in its manifold meanings, the opposite is also true: every experience depends on knowledge, every experiment depends on art: "Omnis experimentum ex arte dependet." 
Felix Diergarten

\section{APPENDIX: SYNOPSIS OF THE PROLOGUES BY ARISTOTLE AND MURIS}

Aristoteles, Metaphysica

Et omnino scientis signum est posse docere. (line $5^{6}$ )

Experti quidem enim ipsum quia sciunt, sed propter quid nesciunt. (46)

Non scientia autem faciunt quae faciunt, ut ignis exurit. (51)

Sed tamen scire et intelligere magis arte quam experimento esse arbitramur...

... et artifices expertis sapientiores esse opinamur. (42)

Et ob hoc artem magis experimento scientiam esse existamamus. (57)

Possunt enim hii, hii autem docere non possunt. (58)

Causa autem est quia experientia quidem singularium est cognitio, ars vero uniuersalium. $(34)$

Experientia quidem enim artem fecit. (22) ... et expertos magis proficere videmus sine experientia rationem habentibus (32).

Aristoteles, Metaphysica 1.1, twelfth- or thirteenth-century translation by Guilielmus de Morbeka (Aristoteles 1995, 12-13).
Johannes de Muris, Notitia artis musicae

Princeps philosophorum Aristoteles ait in prooemio Metaphysicae suae:

Omnino scientis signum est posse docere.

In qualibet autem arte theorici docere possunt, practici vero non.

Experti enim ipsum quia sciunt, sed propter quid nesciunt.

Non autem scientia faciunt, quae faciunt ut ignis exurit.

Sed intellegere et scire circa unamquamque artem magis arte quam experimento esse arbitramur.

Ideoque artifices expertis sapientiores esse opinamur.

Et ob hoc artem magis experimento scientiam esse existimamus.

Possunt enim hii, hii autem docere non possunt.

Quoniam tamen ars est universalium, experimentum vero singularium,

universalia praesupponunt singularia, igitur ars experientiam praesupponit.

Experientia quidem fecit artem et expertos magis proficere videmus rationem sine experientia habentibus.

Igitur necessarium est in unaquaque arte habere primo [scientiam] theoricam, practicam convenienter, ut illud, quod scitum est in universali, ad singulare valeat applicari.

Sed cum omnis ars ex experimentis dependeat, oportet unumquemque artificem primo circa artis experientiam laborare.

Nos autem propter bonum commune et ratione veritatis, quae diu latuit, ostendendae circa artem musicae proponimus vigilare, intendentes circa eam duo breviter enodare: primo theoricam, secundo practicam, cui con est inconveniens, quodammodo quamdam theoricam implicari.

Johannes de Muris, Notitia artis musicae (Muris 1972, 47-48).
Translation

Aristotle, the prince of philosophers, says in the prologue to his Metaphysics:

In general the ability to teach is a distinguishing mark of those who have knowledge.

In every ars the theorici know how to teach, the practici not.

For the experti know the "that" but not the "because."

The experti do not do scientia, because they behave like burning fire [burning without knowing that it burns].

We think that knowledge and insight belong to ars rather than to experimentum.

Therefore we assume that artists are wiser than the [merely] experienced.

That is why we think that ars, rather than experimentum, is scientia.

They [the artists/theorici] can teach, whereas they [the experti/pratici, the merely experienced] cannot.

But because experientia/experimentum is the knowledge of particulars and ars that of universals,

and because universals presuppose particulars, ars presupposes experientiam.

Experientia produced ars and we rather observe those with experientia being more successful than those who have a theoretical understanding without experientia.

Therefore it is necessary in every ars to have in the first place theoretical knowledge in a manner appropriate to practical knowledge, so that knowledge of universals can be applied to the particular.

But since every ars depends on experiences, artifex should first labour in the field of artistic experience.

We, however, serving a common good and a truth, which has been concealed for a long time, propose to write about the ars musica in the following, and intend to clarify briefly first [musica] theorica and then practica, for which it is not inconvenient that some theory be closely entwined. 


\section{REFERENCES}

Adorno, Theodor W. (1962) 1992. "Vers une musique informelle.” In Quasi una fantasia: Essays on Modern Music, translated by Rodney Livingstone, 269-322. London: Verso. Essay first published 1962 (Darmstädter Beiträge zur Neuen Musik 4: 73-102). Book first published 1963 as Quasi una fantasia: Musikalische Schriften II (Frankfurt am Main: Suhrkamp).

Aristoteles. 1970. Metaphysica: Lib. I-IV. 4: Translatio Iacobi sive Vetustissima cum scholiis et translatio composita sive Vetus. Edited by Gudrun Vuillemin-Diem. Aristoteles Latinus 25.1.1a. Leiden: Brill. - 1973. Ethica Nichomachea. Translated by Robert Grosseteste. Edited by René Antoine Gauthier. Aristoteles Latinus 26.1-3. Leiden: Brill.

-_- 1976. Metaphysica, Lib. I-X, XII-XIV: Translatio anonyma sive "media." Edited by Gudrun Vuillemin-Diem. Aristoteles Latinus 25.2. Leiden: Brill. . 1990. Physica: Translatio vetus. Edited by Fernand Bossier and Jozef Brams. Aristoteles Latinus 7.1.1. Leiden: Brill. . 1995. Metaphysica, Lib. I-XIV:

Recensio et translatio Guillelmi de Moerbeka. Edited by Gudrun Vuillemin-Diem. 2 vols. Aristoteles Latinus 25.3. Turnhout, Belgium: Brepols.

. 2011. Zweite Analytik: Analytica

Posteriora. Edited by Wolfgang Detel. Hamburg: Meiner.

Bacon, Francis. (1620) 1878. Novum organum. Edited by Thomas Fowler. Oxford: Clarendon Press. First published 1620 (London).

Barnes, Jonathan, trans. 1975. Aristotle's Posterior Analytics, with a commentary by Jonathan Barnes. Clarendon Aristotle Series. Oxford: Oxford University Press / Clarendon Press.

Bower, Calvin. 2002. "The Transmission of Ancient Music Theory into the Middle Ages." In The Cambridge History of Western Music Theory, edited by Thomas Christensen, 136-67. Cambridge: Cambridge University Press.

Detel, Wolfgang. 2011. "Einführung." In Aristoteles 2011, xi-xcvi.

Falkenroth, Christoph. 1992. Die Musica speculativa des Johannes de Muris. Beihefte zum Archiv für Musikwissenschaft 34 .
Stuttgart: Steiner.

Gallo, Alberto. 1974. "Lo Studio della Musica speculativa di Iohannes de Muris in Polonia e in Italia: Le glosse dell'Università di Cracovia e i Glossemata di Franchino Gaffurio.” In Primo incontro con la musica italiana in Polonia: Dal Rinascimento al Barocco, 48-54. Miscellanee Saggi Convegni 7. Bologna: A.M.I.S. - 1984. "Die Notationslehre im 14. und 15. Jahrhundert.” In Die mittelalterliche Lehre von der Mehrstimmigkeit, edited by Frieder Zaminer, 257-356. Geschichte der Musiktheorie 5. Darmstadt: Wissenschaftliche Buchgesellschaft.

Goehr, Lydia. 2008a. Preface to Elective Affinities: Musical Essays on the History of Aesthetic Theory, ix-xviii. New York: Columbia University Press. . 2008b. "Explosive Experiments and the Fragility of the Experimental." In Elective Affinities: Musical Essays on the History of Aesthetic Theory, 108-35. New York: Columbia University Press.

Gushee, Lawrence, C. Matthew Balensuela, and Jeffrey Dean. 2001. "Muris, Johannes de.” In Grove Music Online. Accessed 4 December 2014. http://www.oxfordmusiconline.com.

Haas, Max. 1974. "Musik zwischen Mathematik und Physik: Zur Bedeutung der Notation in den Notita artis musicae des Johannes de Muris (1321)." In Festschrift für Arno Volk, edited by Carl Dahlhaus and Hans Oesch, 31-46. Köln: Gerig.

\footnotetext{
___ 1982. "Studien zur mittelalterlichen Musiklehre I: Eine Übersicht über die Musiklehre im Kontext der Philosophie des 13. und frühen 14. Jahrhunderts." In Aktuelle Fragen der musikbezogenen Mittelalterforschung: Texte zu einem Basler Kolloquium des Jahres 1975, edited by Hans Oesch and Wulf Arlt, 323-456. Forum Musicologicum 3. Winterthur: Amadeus. - 1984. "Die Musiklehre im 13. Jahrhundert von Johannes de Garlandia bis Franco." In Die mittelalterliche Lehre von der Mehrstimmigkeit, edited by Frieder Zaminer, 89-160. Geschichte der Musiktheorie 5. Darmstadt: Wissenschaftliche Buchgesellschaft.
} 
-_- 2007. Musikalisches Denken im Mittelalter: Eine Einführung. 2nd ed. Bern: Lang.

Hackett, Jeremiah. 1998. "Experientia, Experimentum and Perception of Objects in Space: Roger Bacon." In Raum und Raumvorstellungen im Mittelalter, edited by Jan A. Aertsen and Andreas Speer, 101-20. Miscellanea mediaevalia 25. Berlin: De Gruyter.

-__ 2013. "Roger Bacon." In Stanford Encyclopedia of Philosophy, winter $2013 \mathrm{ed}$. edited by Edward N. Zalta. Accessed 6 December 2014. http://plato.stanford. edu/entries/roger-bacon.

Harne, George A. 2010. "The Ends of Theory and Practice in the Speculum Musicae." Musica Disciplina 55: 5-31.

Hentschel, Frank. 1994-2007a. "Jacobus von Lüttich." In Die Musik in Geschichte und Gegenwart, edited by Ludwig Finscher, 28 vols., Personenteil 9: 823-27. Kassel: Bärenreiter; Stuttgart: Metzler.

___. 1994-2007b. "Johannes de Muris.” In Die Musik in Geschichte und Gegenwart, edited by Ludwig Finscher, 28 vols., Personenteil 9:1101-7. Kassel: Bärenreiter; Stuttgart: Metzler.

-——. 200o. Sinnlichkeit und Vernunft in der mittelalterlichen Musiktheorie: Strategien der Konsonanzwertung und der Gegenstand der musica sonora um 1300. Beihefte zum Archiv für Musikwissenschaft 47. Stuttgart: Steiner.

_- _ 2011. "The Sensuous Music Aesthetics of the Middle Ages: The Cases of Augustine, Jacques de Liège and Guido of Arezzo.” Plainsong and Mediaeval Music 20 (1): 1-29.

Herzberg, Stephan. 2011. Wahrnehmung und Wissen bei Aristoteles: Zur epistemologischen Funktion der Wahrnehmung. Berlin: De Gruyter.

Holtmeier, Ludwig. 1997. "Nicht Kunst, nicht Wissenschaft: Zur Lage der Musiktheorie." Musik E Ästhetik 1 (1-2): $119-36$.

- _ 2012. "Feindliche Übernahme: Gottfried Weber, Adolf Bernhard Marx und die bürgerliche Harmonielehre des 19. Jahrhunderts." Musik \& Ästhetik 63: $5^{-25}$.

Jacobus Leodiensis. 1955-73. Speculum musicae. Edited by Roger Bragard. 7 vols. Corpus scriptorum de musica 3 . Rome:
American Institute of Musicology.

Jüttner, Guido. 1989. “Experimentum.” In Erzkanzler bis Hiddensee, vol. 4 of Lexikon des Mittelalters, 184-85. Munich: Artemis. Kessler, Alfred S., Alfred Schöpf, and Christoph Wild. 1973. "Erfahrung." In Dialektik-Gesellschaft, vol. 2 of Handbuch philosophischer Grundbegriffe, edited by Hermann Krings, Hans Michael Baumgartner, and Christoph Wild, 373-86. Munich: Kösel.

Koselleck, Reinhart. 1979. Vergangene Zukunft: Zur Semantik geschichtlicher Zeiten. Frankfurt am Main: Suhrkamp. Translated by Keith Tribe as Futures Past: On the Semantics of Historical Time (Cambridge, MA: MIT Press, 1985).

Leitmeir, Christian Thomas. 2013. "Sine auctoritate nulla disciplina est perfecta: Medieval Music Theory in Search of Normative Foundations." In Between Creativity and Norm-Making: Tensions in the Later Middle Ages and the Early Modern Era, edited by Sigrid Müller and Cornelia Schweiger, 31-6o. Leiden: Brill.

Lutz-Bachmann, Matthias. 2007.

"Experientia bei Thomas von Aquin." In Erfahrung und Beweis: Die Wissenschaften von der Natur im 13. und 14. Jahrhundert / Experience and Demonstration: The Sciences of Nature in the 13th and 14th Centuries, edited by Alexander Fidora and Matthias Lutz-Bachmann, 153-62. Wissenskultur und gesellschaftlicher Wandel 14. Berlin: Akademie Verlag.

Memelsdorff, Pedro. 2008. “'Ars Modernior': Le avanguardie musicali italiane del primo Quattrocento." In Musica e arti figurative: Rinascimento e Novecento, edited by Mario Ruffini and Gerhard Wolf, 59-73. Venice: Marsilio.

Mensching, Günther. 1992. Das Allgemeine und das Besondere: Der Ursprung des modernen Denkens im Mittelalter. Stuttgart: Metzler.

———. 2009. Roger Bacon. Zugänge zum Denken des Mittelalters 4. Münster: Aschendorff.

Michels, Ulrich. 1970. Die Musiktraktate des Johannes de Muris. Beihefte zum Archiv für Musikwissenschaft 8. Wiesbaden: Steiner. Mittellateinisches Wörterbuch bis zum ausgehenden 13. Jahrhundert. 1956-. Edited by Bayerische Akademie der Wissenschaften and BerlinBrandenburgische Akademie der 


\section{Omnis ars ex experimentis dependeat}

Wissenschaften. 3 vols. to date. Munich: Beck.

Muris, Johannes de. 1972. Notitia artis musicae et Compendium musicae practicae. Edited by Ulrich Michels. Corpus scriptorum de musica 17. [Rome]: American Institute of Musicology.

[Jean de Murs]. 20oo. Ecrits sur la musique. Translated and edited by Christian Meyer. Paris: CNRS éditions.

Muris, [Pseudo-]Johannes de. 1869. "Ars contrapuncti." In Scriptorum de musica medii aevi, Nova seriem a Gerbertina alteram collegit, edited by Edmond de Coussemaker, 4 vols., 3:59-68. Paris: A. Durand.

Petrarca, Francesco. 1990. De vita solitaria: Kritische Textausgabe und ideengeschichtlicher Kommentar von K. A. E. Enenkel. Leidse romanistische reeks van de Rijksuniversiteit te Leiden 24. Leiden: Brill.

Prosdocimus de Beldemandis. 1984. Contrapunctus. Edited and translated by Jan Herlinger. Greek and Latin Music Theory 1. Lincoln: University of Nebraska Press.

Quintilianus, Marcus Fabius 1972. Institutionis oratoriae, Libri XII. Edited by Helmut Rahn. 2 vols. Darmstadt: Wissenschaftliche Buchgesellschaft.

Riethmüller, Albrecht. 1990. "Probleme der spekulativen Musiktheorie im Mittelalter." In Rezeption des antiken Fachs im Mittelalter, edited by Frieder Zaminer, 163-201. Geschichte der Musiktheorie 3. Darmstadt: Wissenschaftliche Buchgesellschaft.

Rüegg, Walter, ed. 1993. Mittelalter. Vol. 1 of Geschichte der Universität in Europa. Munich: Beck.

Sachs, Klaus-Jürgen. 1974. Der Contrapunctus im 14. und 15. Jahrhundert: Untersuchungen zum Terminus, zur Lehre und zu den Quellen. Beihefte zum Archiv für Musikwissenschaft 13. Wiesbaden: Steiner.

Sarnowsky, Jürgen. 2012. “Expertusexperientia-experimentum: Neue Wege der wissenschaftlichen Erkenntnis im Spätmittelalter." Das Mittelalter 17 (2): 47-59.
Saxer, Marion. 2007. "Nichts als Bluff? Das Experiment in Musik und Klangkunst des 20. Jahrhunderts bis zur Gegenwart.” Musik E Ästhetik 43: 53-67.

Schmitt, Arbogast. 2003. Die Moderne und Platon. Stuttgart: Metzler. Translated by Vishwa Adluri as Modernity and Plato: Two Paradigms of Rationality (Rochester, NY: Camden House, 2012).

Stierle, Karlheinz. 2003. Francesco Petrarca: Ein Intellektueller im Europa des 14. Jahrhunderts. Munich: Hanser.

Tanay, Dorit E. 1989. "Music in the Age of Ockham: The Interrelations between Music, Mathematics, and Philosophy in the 14th Century." PhD thesis, University of California, Berkeley. . 1993. "Jehan de Meur's Musical Theory and the Mathematics of the Fourteenth Century." Tractrix 5: 17-43.

$$
\text { _—_ 1999. Noting Music, Marking Culture: }
$$

The Intellectual Context of Rhythmic Notation, 1250-1400. Musicological Studies and Documents 46. N.p.: American Institute of Musicology; Holzgerlingen: Hänssler-Verlag.

Taruskin, Richard. (1981) 1995. "On Letting the Music Speak for Itself." In Text and Act: Essays on Music and Performance, 51-66. New York: Oxford University Press. Originally read at the national meeting of the American Musicological Society, Boston, 13 November 1981 . First published 1982 as "On Letting the Music Speak for Itself: Some Reflections on Musicology and Performance" (Journal of Musicology 1 [3]: 338-49).

Thesaurus Linguae Latinae. 1931-53. Vol. V 2, E. Berlin: De Gruyter.

Treitler, Leo. 1974. "Homer and Gregory: The Transmission of Epic Poetry and Plainchant." The Musical Quarterly 6o (3): $333-72$.

Tuninetti, Luca. 2011. “Scholastik.” In Aristoteles-Handbuch: Leben, Werk, Wirkung, edited by Christof Rapp and Klaus Corcilius, 428-36. Stuttgart: Metzler.

Welsch, Wolfgang. 2012. "Der Philosoph: Die Gedankenwelt des Aristoteles.” Paderborn, Germany: Fink. 


\title{
"Vieltönigkeit" instead of Microtonality
}

\section{The Theory and Practice of Sixteenth- and Seventeenth-Century "Microtonal" Music}

\author{
Martin Kirnbauer \\ University of Basel
}

\begin{abstract}
Preliminary remark: this text stems from a lecture given in June 2011 at the conference Mikrotonalität-Praxis \&. Utopie (Microtonality-Praxis and Utopia), which took place at the Staatliche Hochschule für Musik und Darstellende Kunst in Stuttgart; this, in turn, was based upon my contribution to the 2011 International Orpheus Academy, “Vieltönige Musik'-Performance Practice of Chromatic and Enharmonic Music in the 16th and 17th Centuries." Both events featured performances of a number of the music examples by Johannes Keller on a "cimbalo cromatico"- that is, a harpsichord with twenty-four keys to the octaveaccompanied by the soprano Gunhild Lang-Alsvik and the violinist Eva Saladin. ${ }^{1}$
\end{abstract}

"Microtones" and "microtonality"- both the words themselves and the concepts behind them - are a phenomenon of recent music history, as a brief glance in a music dictionary demonstrates: the 1967 Riemann Musik-Lexikon does not recognise the term, for example, and "Mikrotöne" only appears in the first edition of Bärenreiter's Musik in Geschichte und Gegenwart as a translation of the English term "microtones" (in reference to the works of Edgard Varèse, among others). In contrast, the New Grove (2001) has a whole article on the term; although this includes a pragmatic definition ("Any musical interval or difference of pitch distinctly smaller than a semitone"), it also suggests that the use of microtones in Western art music is above all a phenomenon of the twentieth century (with reference to composers such as Julián Carrillo, Alois Hába, and Charles Ives) (Griffiths, Lindley, and Zannos 2001, 16:624-25). There is further material under the headword "quartertone," a comparatively restricted form of microtonality, and one that Klaus Huber describes as simply an extended or

\footnotetext{
DOI http://dx.doi.org/10.11116/9789461661883.cho3

1 These important live recordings can be heard online at http://www.orpheusinstituut.be/en/ experimental-affinities-in-music-repository
} 
compounded version of the semitonal "panchromaticism" that he criticises; ${ }^{2}$ but here, too, the evidence only begins at the end of the eighteenth century.

The view that microtonality is a modern phenomenon is primarily conceptually motivated. The terminology itself already implies that the idea is based around a constitutive "whole tone" (from the Greek tóvo $\varsigma$ ), which is then made smaller (Greek ıкрó, , "small” or "narrow"). The basic major scale of Western music already contains not only "whole tones" such as major seconds (C-D, $\mathrm{D}-\mathrm{E}, \mathrm{F}-\mathrm{G}, \mathrm{G}-\mathrm{A}$, and $\mathrm{A}-\mathrm{B}$ ) but also minor seconds (E-F and B-C), which are referred to as semitones. If these semitonal steps-which are inherent in the system, and thus "natural"-are carried over to the remaining degrees of the basic scale, the result is a scale that is already potentially "microtonal," since it is indeed made up of "smaller whole tones," in this case semitones. That might seem pedantic, but in fact it has great practical relevance. This is evident from a glance at the keyboard of a modern grand piano, a structure that still exerts a decisive influence upon the way we imagine music. Here, the "natural" basic scale is provided by the seven (white) lower keys, while the five (black) upper keys represent the "artificial" semitones. ${ }^{3}$ Although the black and white keywork separates the two in both position and colour, it nonetheless shows a division of the scale into equal semitones; but this can only be achieved within an equal-tempered tuning system, in which all intervals of a tone are defined to be exactly the same size. Quarter- and third-tone scales also presuppose equal-tempered tuning; although this concept is present in sixteenth-century music theory, it was only in the nineteenth and early twentieth centuries that it gradually established itself in practice. ${ }^{4}$

As soon as we leave behind the beautifully ordered but monochrome world of the keyboard, with its seven white and five black keys and its equal temperament, and change the size of one of these intervals-perhaps when a semitone is stretched to be a leading note, or when a pure and untempered interval is needed-then we are immediately left with a "microtone" that cannot be represented on this keyboard. The seven degrees of the scale (C, D, E ...), along with the sharpened and flattened forms $(\mathrm{C} \#, \mathrm{D} \#, \mathrm{E} \# \ldots$ and $\mathrm{C} b, \mathrm{D} b, \mathrm{E} b \ldots$, as well as double-sharps and double-flats) allowed by notation, are mapped onto only twelve keys, and thus only twelve degrees that can actually be heard. Originally, however, the manifold possibilities for chromatic alteration offered by notation were not just quirks of musical orthography; rather, each corresponded to a different pitch.

Thus, although before the end of the nineteenth century there was no microtonality in the sense of artificial divisions of the whole tone, used freely like blocks in a construction set, it was taken for granted that there were distinc-

2 See Huber (1999), especially “Nähe und Distanz: Zum Streichtrio 'Des Dichters Pflug”' (224-34) and "Für einen lebendigeren Orgelklang: Stimmungssysteme, Temperatur, Mikrotonalität" (83-88).

3 As an aside, it should be noted that this historically justified keyboard layout, which dates back to the late fourteenth century, is actually not very well suited to the music of later centuries; hence the appearance of proposed reforms such as the "Jankó keyboard," none of which, interestingly, have ever caught on. But that is another topic.

4 As well as the more well-known titles that are relevant to this topic, reference should be made here to Di Veroli (2008) and to two further original contributions: Duffin (2007) and Eck (2010). 


\section{Martin Kirnbauer}

tions to be made between the small and large semitones produced automatically by certain temperaments, and between those and even smaller intervals (those referred to as dieses, for example), all of which were called for in a wide variety of contexts. To capture this phenomenon, which is above all a practical one, I use the term "vieltönig" (which perhaps can be translated as "multitonal" in the literal sense of using many pitches). 5 This is used to refer to any pitch system with more than twelve real notes or pitches to the octave, regardless of its theoretical motivation. Although it does not correspond to any historical terminology any more than "microtonal" does, "vieltönig" vividly captures the practical consequences of these systems-demonstrated, for example, by historical keyboard instruments with divided black keys (so-called split sharps), or with expanded keywork (see figure 1). ${ }^{6}$ This Italian harpsichord from 1606 has thirty-one keys to the octave; an inscription on the name-board states the possibilities that this opens up: "Clavemvsicvm Omnitonvm / Modvlis Diatonicis, Cromaticis, et Enarmonicis / a docta manv tactvm." This can be translated as "A musical instrument with keys for all notes that can 'modulate' in the diatonic, the chromatic and the enharmonic, if it is played by a skilful hand" (the claves in "Clavemusicum" are at the same time verbatim the keys that unlock this kind of music).

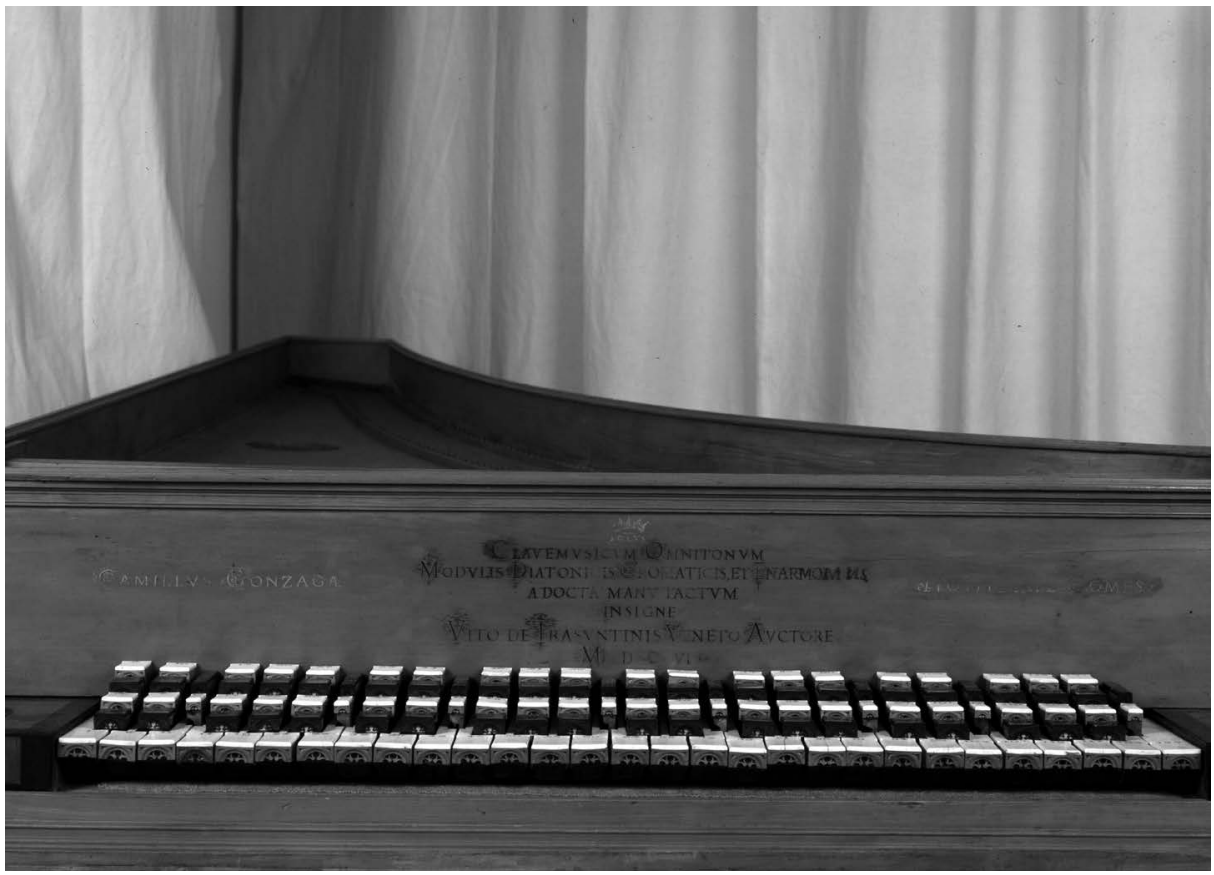

Fig 1.

5 See Kirnbauer (2013), which also provides more detailed discussion of a number of the examples given below.

6 Museo internazionale e biblioteca della musica Bologna, inventory no. 1766. 
With the keywords omnitonum and modulis on the one hand, and the concepts of the diatonic, the chromatic, and the enharmonic on the other, we already have two of the essential ingredients of historical "Vieltönigkeit." The first is concerned with the very practice-oriented field of tunings and temperaments and hence with the precise allocation of notes and scales to fixed pitches; transposition and modulation also play a part, as does an interest in just intonation-the use of mostly untempered pure intervals. While this area has certainly been the subject of extensive theoretical reflection, it is first a practically relevant element of musical performance, one that can also have implications for composition. The second ingredient of Vieltönigkeit is the interest in ancient (above all Greek) music and music theory, with its so-called genera of the chromatic and the enharmonic, among others. This is structural in its effect, with immediate consequences for musical composition.

\section{SONARE FUOR DI STRADA-SPLIT SHARPS AND VIELTÖNIGE KEYBOARDS}

Historically speaking, the first reason to increase the number of notes per octave was required both for purposes of tuning (on the basis of non-equal temperaments) and to transpose a piece of music into a different pitch. Music of the fifteenth and early sixteenth centuries generally stayed in one key, with little or no use of accidentals. However, when a vocal ensemble was accompanied by an organ, problems could easily result, depending on the pitch that the singers wanted to start from and the transposition that would thus be needed, or on the presence of more extended modulations in the music-a problem which Girolamo Diruta (1609, 4:6) described very neatly as "sonare fuor di strada," or "playing off the track."

It is well known that the impossibility of reconciling pure intervals (particularly the fifth and the major and minor third, central to European music) with the purity of octaves, which could not be destabilised, necessitated the practical solution known as temperaments. In the sixteenth and seventeenth centuries, the period under discussion here, a very common and widely circulated temperament was so-called mean-tone, in which thirds were kept as pure as possible and fifths were made correspondingly smaller. ${ }^{7}$ Regardless of the various possibilities and practical techniques that it generated, one aspect of this tuning system is central here: in mean-tone temperament, there is an emphatic difference between the two versions of the same pitch reached by sharpening and flattening, respectively. So, for example, a G\# (as a major third above $\mathrm{E}$ ) is different in pitch from an $\mathrm{A} b$ (as a minor third above $\mathrm{F}$ ), as a comparison of their cent equivalents illustrates (figure 2).

7 The literature on this subject is plentiful; the reader is referred here only to Lindley (1987). 


\begin{tabular}{|l|r|r|r|}
\multicolumn{1}{c}{} & Mean-tone & Equal & Just \\
\hline C & 0 & 0 & 0 \\
\hline C\# & 76 & 100 & 71 \\
\hline D $b$ & 117 & 100 & 112 \\
\hline D & 193 & 200 & 204 \\
\hline D\# & 269 & 300 & 275 \\
\hline E $b$ & 310 & 300 & 316 \\
\hline E & 386 & 400 & 386 \\
\hline E\# & 462 & 500 & \\
\hline Fb & 427 & 400 & \\
\hline F & 503.5 & 500 & 498 \\
\hline F\# & 580 & 600 & 590 \\
\hline G b & 620.5 & 600 & 610 \\
\hline G & 696.5 & 700 & 702 \\
\hline G\# & 772.5 & 800 & 773 \\
\hline A b & 814 & 800 & 814 \\
\hline A & 889.5 & 900 & 884 \\
\hline A\# & 966 & 1000 & 977 \\
\hline B b & 1007 & 1000 & 1018 \\
\hline B & 1083 & 1100 & 1088 \\
\hline B \# & 1159 & 1200 & \\
\hline C b & 1124 & 1100 & \\
\hline C & 1200 & 1200 & 1200 \\
\hline
\end{tabular}

Fig. 2.

Here a kind of Vieltönigkeit is revealed that is all but inherent in the system. It can be realised on keyboard instruments through the use of additional "split" keys; on other instruments, which do not rely on fixed scales, the intonation can be adjusted accordingly using changes of fingering or embouchure. Evidence for expanded keyboards - and thus for the real-world availability of vieltönige tunings based on more than twelve keys per octave-is found from around $145^{\circ}$ onwards, and particularly after $155^{\circ}$; it is most clearly documented up to around 1650 , but examples continue in the 1700 and even as far as $1850 .{ }^{8}$ At that point, however, the musical world seems largely to have resigned itself to the limitations of the twelve-key (and hence twelve-pitch) system - a situation that also highlights the triumph of the pianoforte, whose capabilities in this respect are severely constrained.

8 These run from the keyed monochord of Conrad von Zabern in the 1400 s to "enharmonic organs" such as that described by Thomas Perronet Thompson or the "enharmonic piano" built in 1864 for Prince Vladimir Fyodorovich Odoyevsky; for an overview-by no means exhaustive—see Wraight and Stembridge (1994); Ortgies (2003); Barbieri (2008). 
Evidence is found comparatively frequently for keyboards with fourteen keys— the two additional keys usually being assigned to $\mathrm{G} \sharp / \mathrm{A} b$ and $\mathrm{D} \# / \mathrm{E} b$ - as well as for those with sixteen, nineteen, twenty-four, and even thirty-one keys. The nineteen-pitch instrument depicted in Gioseffo Zarlino's Le istitutioni harmoniche ( $155^{8}$ ) is today called a "cimbalo cromatico" (figure 3); it offers a complete set of split sharps, as well as additional keys between the semitones of the white keys $\mathrm{E}-\mathrm{F}$ (for $\mathrm{E} \#$ or $\mathrm{F} b$ ) and $\mathrm{B}-\mathrm{C}$ (for $\mathrm{B} \#$ or $\mathrm{C} b$ ). ${ }^{9}$ The name of the "cimbalo cromatico" already implies the second aspect of Vieltönigkeit mentioned earlier-its tendency to refer back to the music of antiquity.

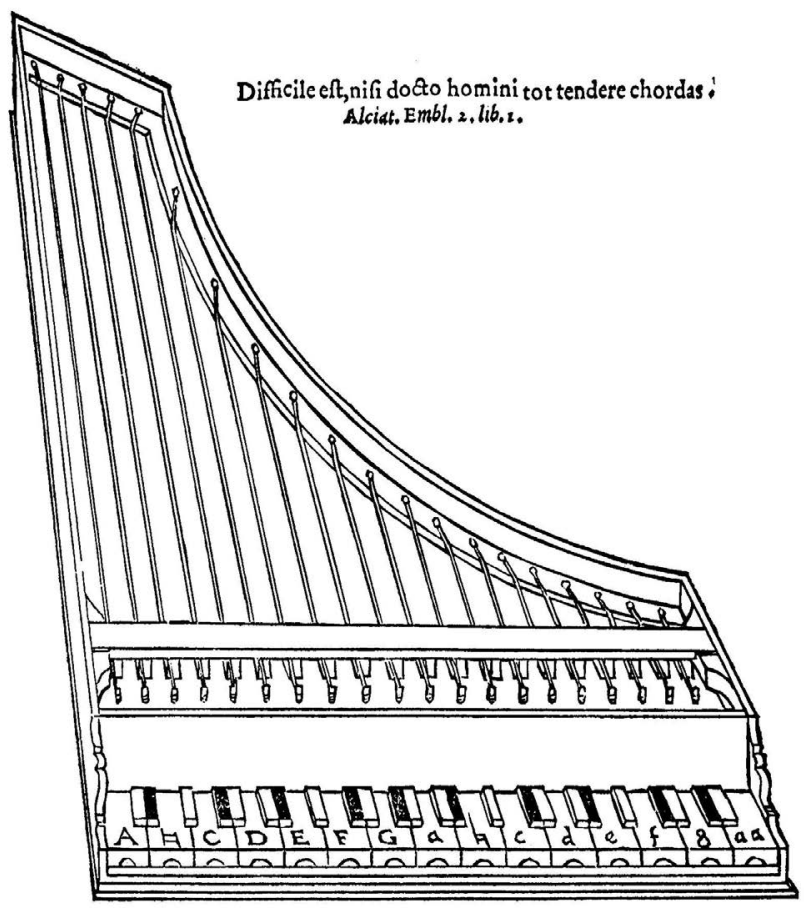

Fig. 3.

\section{L'ANTICA MUSICA RIDOTTA ALLA MODERNA PRATTICA- NICOLA VICENTINO AND VIELTÖNIGKEIT}

While certain aspects of ancient Greek music theory remained influential throughout the Middle Ages, passed on through treatises, from the fifteenth century onwards a growing interest in this body of knowledge can be observed, provoked (among other things) by the rediscovery of manuscripts that had formerly been lost (see Palisca 1985). As part of this process of looking back, which today tends to be associated loosely with humanism or the Renaissance, there

9 For a proposed systematic terminology, see Rasch (2002, 21-33); for other similar instruments, see Wraight $(2002,105-36)$. 
were also practical attempts to revive certain elements of ancient music (as far as it was understood at the time). The background for this revival was formed (in part) by reports passed on from antiquity, telling of music's legendary powers-powers that were quite obviously lacking in the music of the time.

The elements of ancient (i.e., Greek) music that thereby came under scrutiny included the so-called diatonic, chromatic, and enharmonic genera. In very rough terms, these describe the arrangement of pitches within the interval of a fourth, in the so-called tetrachord (see figure 4). The diatonic genus

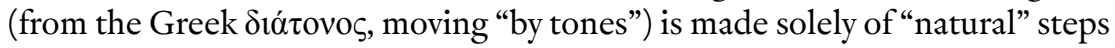
in the sequence semitone-tone-tone (for example, E-F-G-A). The chromatic genus (from the Greek $\chi \rho \omega \alpha$, "colour") was seen as the "coloured" genus, with the sequence semitone-semitone-minor third (for example, E-F-F\#-A). The enharmonic genus (from the Greek $\varepsilon^{\prime} v \alpha \rho$ óvios, set in the "harmonia") fills in the tetrachord with two microintervals called the pyknon (meaning "dense") and a major third (for example, E-Ex-F-A). ${ }^{10}$ The ancient Greek theory of the genera is fairly complex (and the details of its practical usage are not wholly clear), but that is irrelevant for what follows; here what is important is the way that composers of the sixteenth century dealt with it.

One of the most influential figures in the attempted rehabilitation of the genera was Nicola Vicentino (1511-1576/77), whose text L'antica musica ridotta alla moderna prattica was published in 1555 in Rome. ${ }^{11}$ The practical orientation of this text is evident even in its title: in full, it is "Ancient music restored to modern practice, with an explanation and examples of the three genera and their nature, and the invention of a new instrument, in which is contained the most perfect music, with many musical secrets." ${ }^{12}$ The text also contains the few surviving compositions in this style by Vicentino, which show how his approach might be emulated; almost all his remaining works, including a series of published madrigal collections, have been lost or survive only fragmentarily.

Diatonic

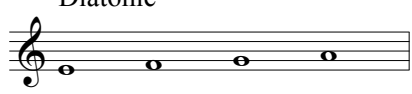

Chromatic

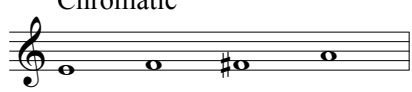

Enharmonic

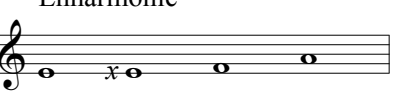

Fig. 4.

10 In this article, " $x$ " is used to denote the enharmonic diesis; this should not be confused with the modern usage of the symbol " $\mathrm{x}$ " for a double sharp.

11 See the excellent English translation and introduction by Maria Rika Maniates (Vicentino 1996), as well as Cordes (2007).

12 L'antica musica ridotta alla moderna prattica, con la dichiaratione, et con gli essempi de i tre generi, con le loro spetie. Et con l"inventione di uno nuovo stromento, nelquale si contiene tutta la perfetta musica, con molti segreti musicali. 
One example of his style is the four-part madrigal "Musica priscat caput,"13 a succinctly programmatic composition, which eulogises the dedicatee of the book, Vicentino's patron Cardinal Ippolito (II) d'Este, while also demonstrating the possibilities of the three genera.

\author{
Musica prisca caput tenebris modo sustulit altis \\ Dulcibus ut numeris priscis certantia factis \\ Facta tua, Hyppolite, excelsum super aethera mittat. (Vicentino 1555, fol. 69v-7ov) \\ Ancient music of late has raised her head out of the darkness, \\ So that, with antique and sweet numbers, to compete with ancient deeds, \\ Your great deeds, Hyppolitus, she might send high above the heavens. (Vicentino \\ 1996, 218n86)
}

Although the first section uses only "diatonic" intervals, in the second section (from bar 16) the intervals of the chromatic genus come into play; it is no coincidence that this accompanies the word dulcibus, conjuring up the particularly "sweet" tonal qualities of "ancient music"-which, for Vicentino, means ancient Greek music. The last section (from bar 31, see figure 5) opens with a prominent textual nod to Cardinal Ippolito, whose glorious deeds happened to include his energetic support of Vicentino's ancient music revival. It ends by presenting enharmonic and chromatic elements such that the melodic progressions in each voice, which (with their abrupt "microtonal" shifts) might sound bizarre by themselves, nonetheless combine to create harmonically pure sounds.

This kind of music was highly sought after as a sort of musical avant-garde in learned Italian circles, but also north of the Alps (certainly in France and Germany, as demonstrated by the Académie de Poésie et de Musique founded by Jean-Antoine de Baif in Paris, or the court of Albrecht V, Duke of Bavaria, where Orlando di Lasso was writing similar music). It was music for a select few, and it is no coincidence that Vicentino was one of the first to use the term "musica reservata" to describe chromatic and enharmonic music "used to praise great personages and heroes for the benefit of refined ears amid the private diversions of lords and princes" (Vicentino 1555, fol. 10v; 1996, 33; fra li priuati sollazzi de Signori e Principi, ad uso delle purgate orecchie in lode di gran personaggi et Heroi s'adoperauno). As well as its status as something intended exclusively for an educated and powerful elite, interest in this music also stemmed from its reputed ability to stir listeners' emotions. One important demonstration of this is the 1565 Council of Trent's decision, during discussions about the reformation of church music, to ask Vicentino to write a mass in the chromatic style (Lockwood 1957, 348-50).

13 For the lecture-recital, the madrigal "Madonna il poco dolce" was chosen- "a confused mixture," as Vicentino puts it, "of three types of genera in accordance with the words ... as an experiment in mixed genera” ( 1555 , fol. $68 \mathrm{r}$, my translation; misto delle spetie di tre Generi confusi, \& misti, in proposito delle parole ... per far esperienza della Musica mista). The enharmonic elements of "Musica prisca caput" can be heard in an audio extract in Wild (2014); they remain exhilarating even for jaded twenty-first-century ears. 

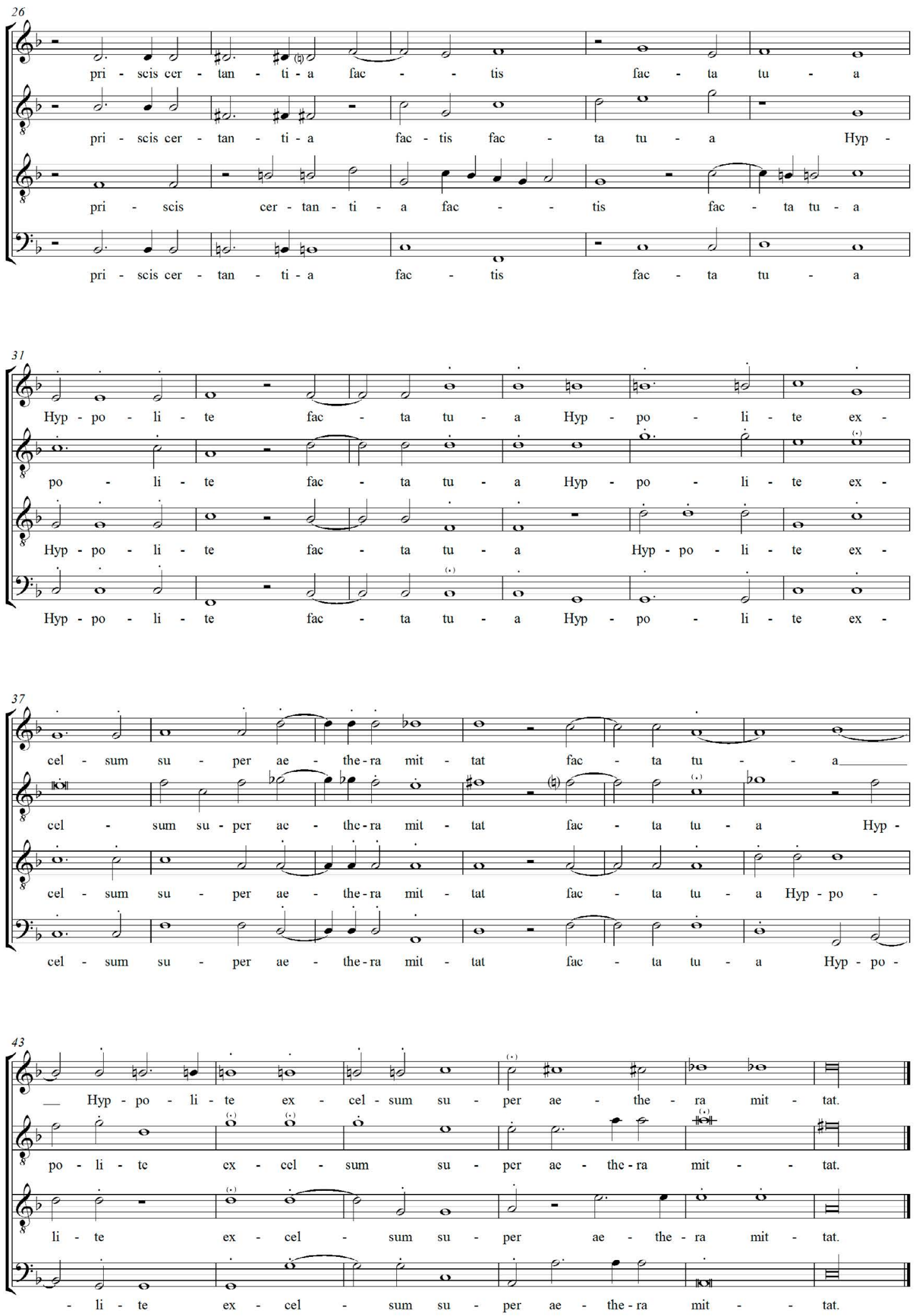

Fig. 5. 
The significance and influence of Vicentino's ideas should not be underestimated, even though he himself was ultimately unsuccessful, his music has largely been lost, and only a few musicians have composed anything that follows his system strictly. He opened the door to an entirely new musical world, and this door, once opened, has left behind audible, vieltönige traces. For Vicentino's concrete application of ancient music to modern practice could actually be described as revolutionary, in that it dramatically expanded the gamut of pitches available to music. Before this point, accidentals were customary only in the context of "musica ficta," which allowed certain diatonic pitches to be raised or lowered from time to time; after Vicentino, any tone could be altered, even by microintervals, as demonstrated by a "musical hand" with solmisation steps in Vicentino's text (figure 6) (Vicentino 1555, fol. 12v). This "mano della diuisione del tono in quattro Diesis Enarmonici" is vieltönig in a very literal sense: it results in many different pitches. All these pitches could be used by a musician or composer-an important step away from musical tradition and from the vocabulary that was normally available to a musician.

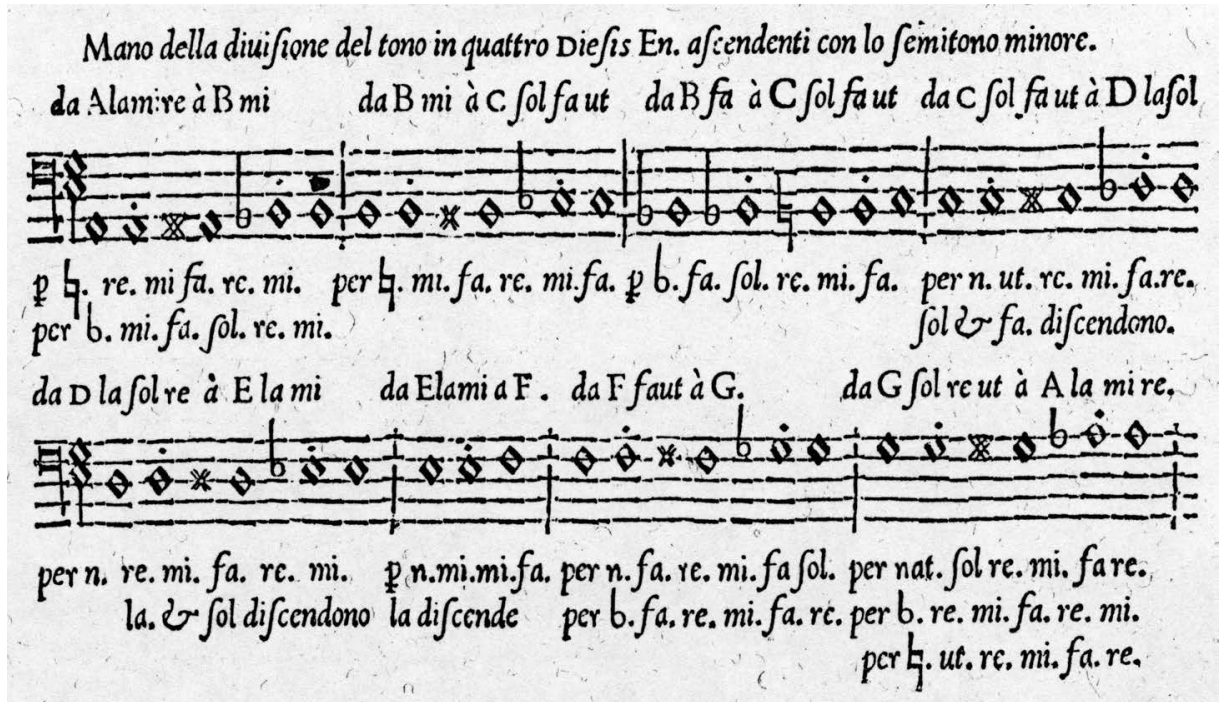

Fig. 6.

The second important aspect arises directly from this: Vicentino also put his novel musical ideas into practice, arranging for the construction of instruments that could realise them (and adding blueprints for some of them to his treatise): an "archicembalo" and "arciorgano," each with thirty-one pitches to the octave (figure 7).14 These instruments took the reservoir of vieltönige pitches seen in the "musical hand" and spread it out vividly in front of the musician, making it concrete, tangible, playable, and audible. But Vicentino and others

14 Reverse of a medallion of Vicentino, attributed to Alessandro Vittoria; this specimen from the Gabinetto Numismatico e Medagliere delle Raccolte artistiche, Milan, inventory no. 1093. 
also spoke about conventional instruments-alongside appropriately trained voices-that could portray this Vieltönigkeit equally well. Alongside violins and trombones, particular mention was made of violas da gamba, because they likewise could make the expanded gamut of pitches easily playable through the addition of extra frets (see Kirnbauer, forthcoming). In each case, the use of specially constructed instruments, or appropriate playing techniques, allowed notated and audible pitch to match each other-the Vieltönigkeit apparent in the notation could actually be heard.

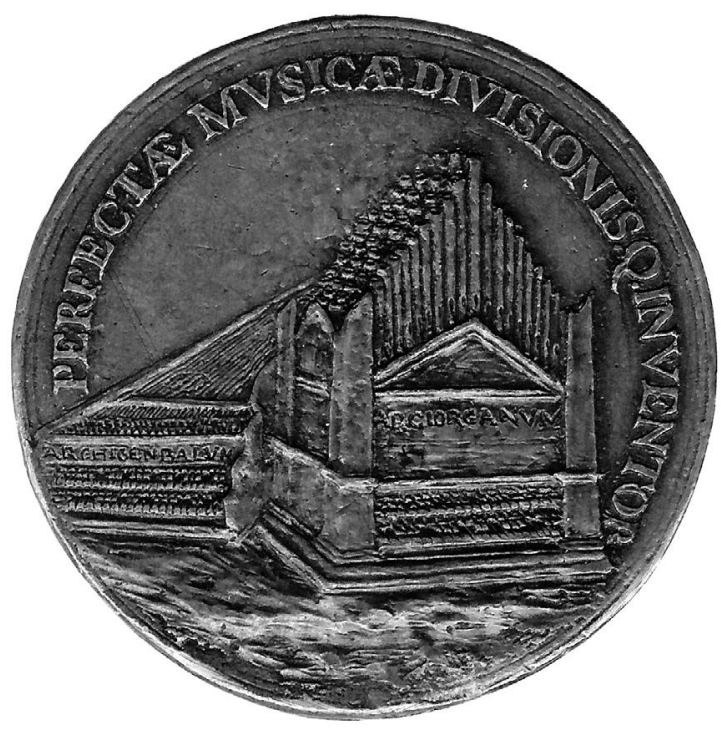

Fig 7.

PER IL CURIOSO MUSICO-VIELTÖNIGE MUSIC, ASCANIO
MAYONE, FABIO COLONNA, AND DOMENICO MAZZOCCHI

The following section presents a few examples of the wide variety of ways in which composers handled the possibilities of Vieltönigkeit, and their increasing presence in apparently conventionally composed and performed music.

Vicentino's expansion of the pitch space available to musicians, which also overlaps to some extent with the "systemic Vieltönigkeit" of mean-tone temperament, was subsequently taken up and explored further. Thus in the second half of the sixteenth century we find music that draws upon Vicentino in a variety of different ways, continuing his line of thought but without any reference to him, and treading this newly expanded tonal space in at least a rudimentary way. ${ }^{15}$ Prime examples of this are the "Madrigali cromatici" (explicitly named as such) printed from 1554 onwards, written by Cesare Tudino, Giulio Fiesco, Lodovico Agostini, and Gioseppe Caimo. Some of these treat the chromatic tetrachord as a soggetto, while others make freer use of the chromatic pitches

15 See James Haar's still seminal contribution "False Relations and Chromaticism in Sixteenth-Century Music" (1977). 
that were now available. In particular, though, it is the madrigal composers of the last third of the sixteenth century who progressively expanded the available pitch space; these included (to name only the most famous) Cipriano de Rore, Luca Marenzio, and Carlo Gesualdo. They used every imaginable alteration of pitch as the occasion dictated, with an enormous influence on the development of our tonal language.

While "chromatic" elements, in the literal sense of the Greek genera, eventually found their way into the common musical language (as is well known), that language remained very limited in its integration of genuinely "enharmonic" elements. This is in part due to the oft-expressed difficulties involved in taking out of their "natural context" the microintervals that are partially present in mean-tone temperament and using them as melodic elements in a polyphonic texture. Here dissonances can only be avoided by abrupt pitch shifts in every part at the same time ${ }^{16}$ or by ensuring that microintervals are only used as melodic decoration in a single voice. In addition, such practices need the support of an instrument that can play all the required pitches-not to mention a musician with the necessary training. For enharmonic music, that means an instrument with thirty-one pitches to the octave, a very expensive purchase even at that time. In reality, however, an instrument of this kind also opened up wholly new musical possibilities and inspired composers to write previously "unheard-of" music.

An interesting example of this is provided by the short pieces commissioned from the Neapolitan composer Ascanio Mayone (c.1565-1627) by the scholar Fabio Colonna (c.1567-1640) and published in the latter's treatise La Sambuca Lincea $(1618,92) .{ }^{17}$ In the text Colonna presents, among other things, his design for a keyboard instrument with thirty-one pitches to the octave, using Mayone's pieces as examples of the musical possibilities of the instrument and of the revived Greek tetrachord, "to make by emulation not only other examples, but with more affect and with more beauty" (Colonna 1618, 92, my translation; ad emulatione affatigarsi non solo à farne de gli altri regolati, ma più affettuosi, \& belli) (see figure $8 \mathrm{a}-\mathrm{d}$ ).

The pieces approach these possibilities in a variety of ways, sometimes taking a more free and economical approach ("Compositione confusa nelli tre gen[er]i" [ibid., 98]), and sometimes adhering carefully to the structure of the chromatic and enharmonic tetrachords (as in the two examples marked intenso [ibid., 94-95])..$^{18}$ It is notable that in each piece at least one voice has a textual underlay, taken from Kyrie eleison or Stabat Mater; although they are meant primarily as examples, they nonetheless make reference to a real musical situation in which they might be used. Finally, one particular characteristic of this process is visible in a short example given to demonstrate an effect described in the text as strisciate (verbatim "to drag"), whereby a voice slides up or down

16 One well-known example of this is found in the chanson "Je suis tellement amoureux" by Antoine de Bertrand (1578, fol. 8).

17 See Barbieri (2008, 393-440).

18 Intenso and molle relate to the different sizes of the microintervals, probably in the sense of strings that have been stretched more tightly (intenso, "tight") or less so (molle, "soft"). 


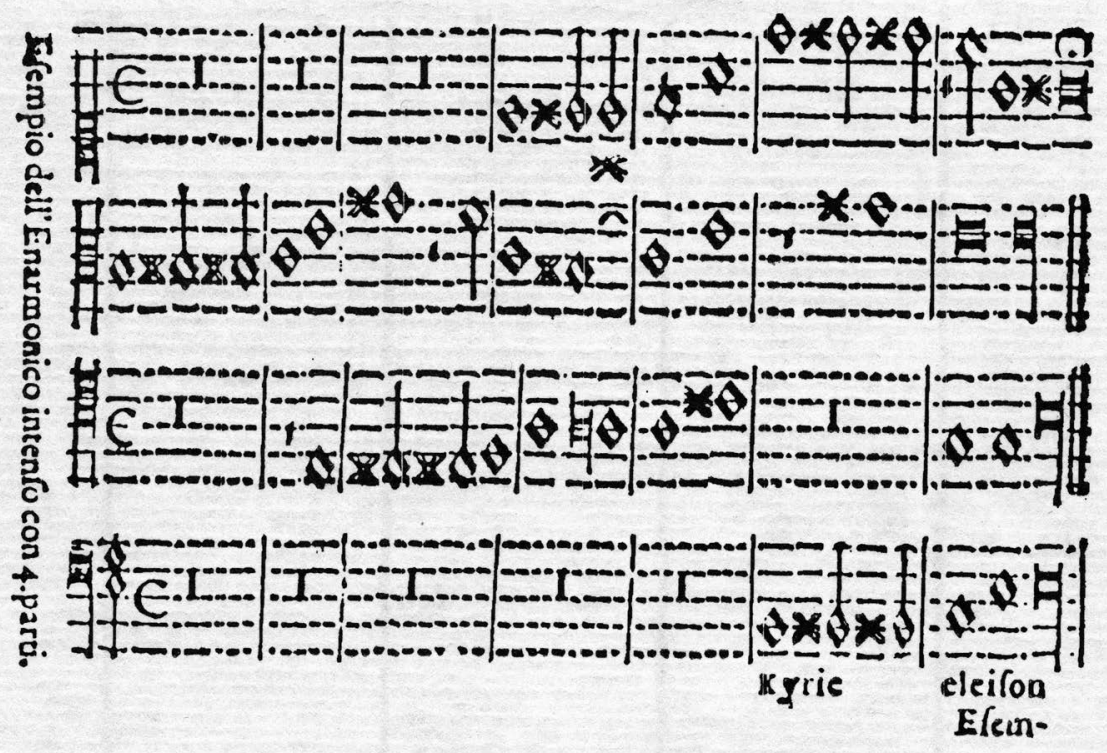

Fig. 8 a

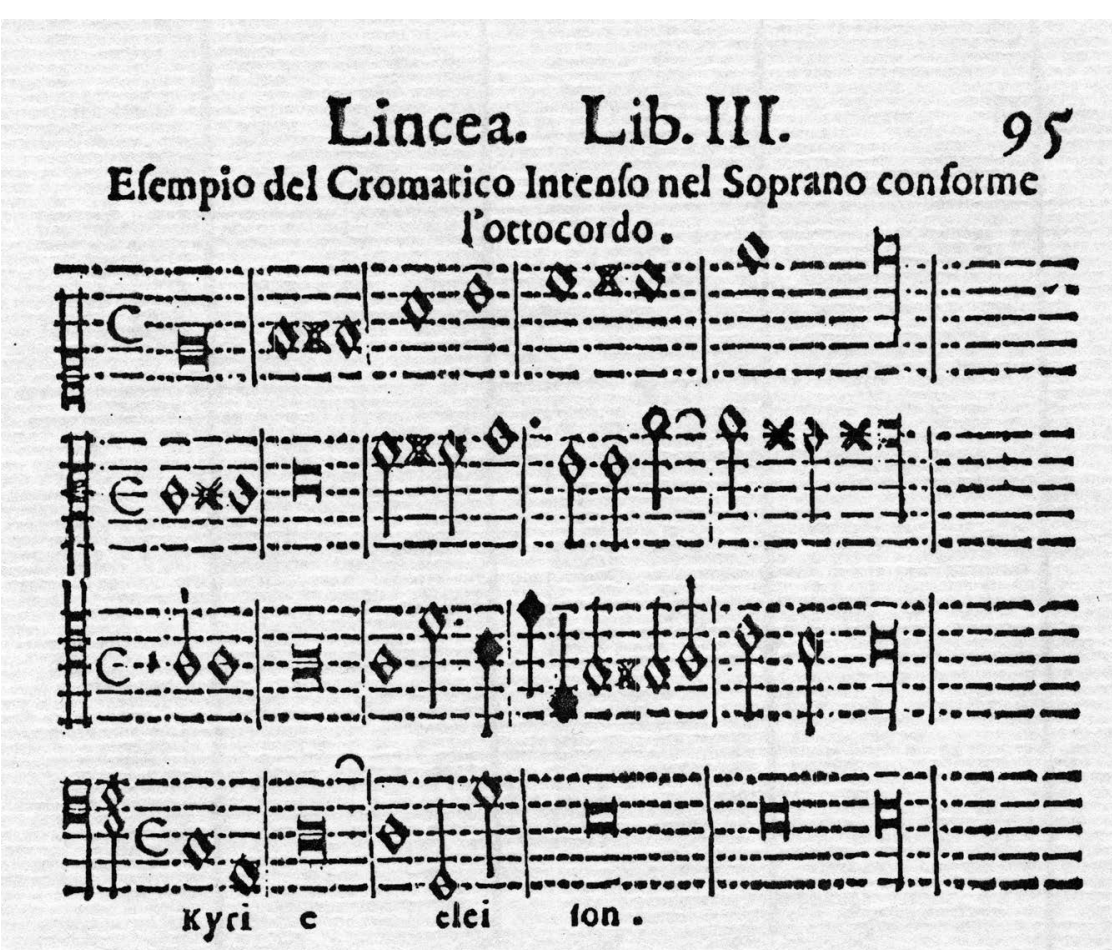

Fig. $8 \mathrm{~b}$ 


\section{Della Sambuca}

Del Diazonieo non fe ne pone effempio per effer cola volgare, \& $f_{2}$ : cile come habbiamo detto di fopra, ma differente dalla vfuales diatonica. che tiene Chromatico mifto nelli tafti neri. Compofitione confufa nelli tre geni.

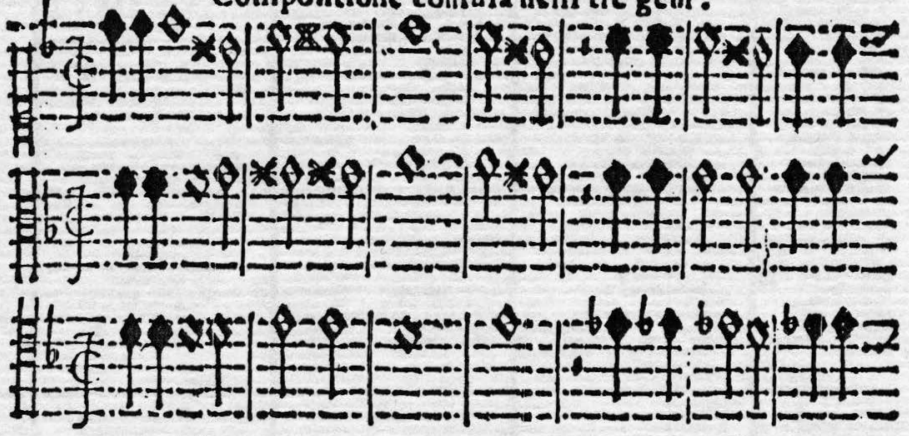

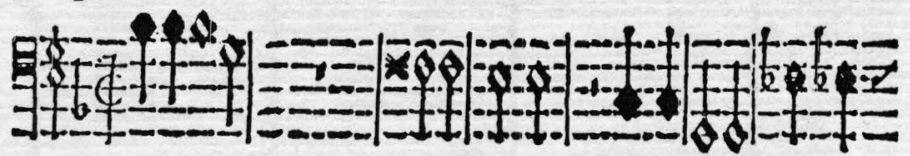
Stabsemater dolorofa iuxea crucem lacti-

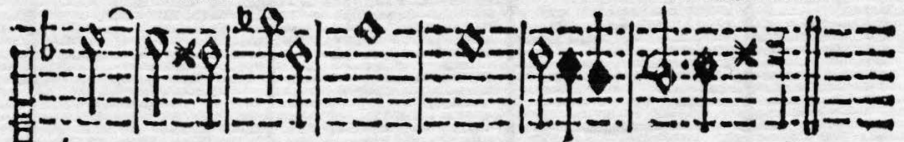

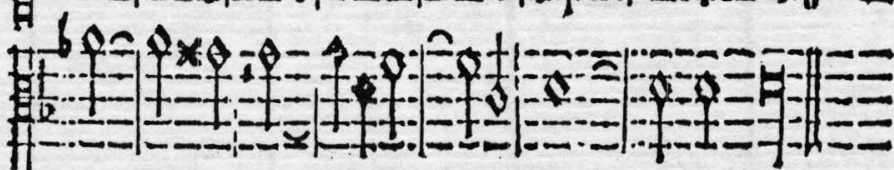

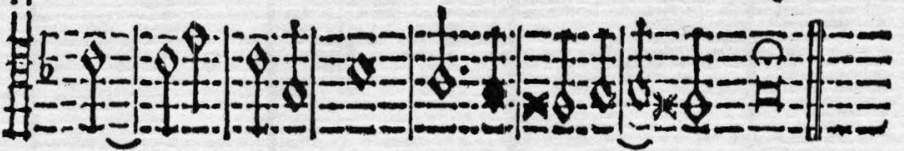

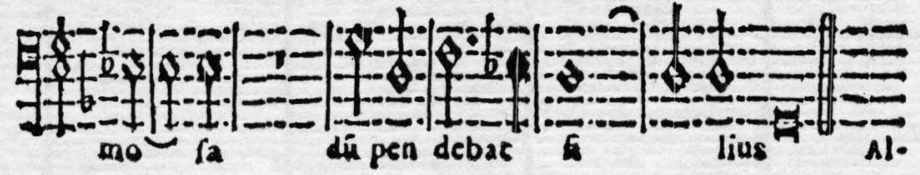

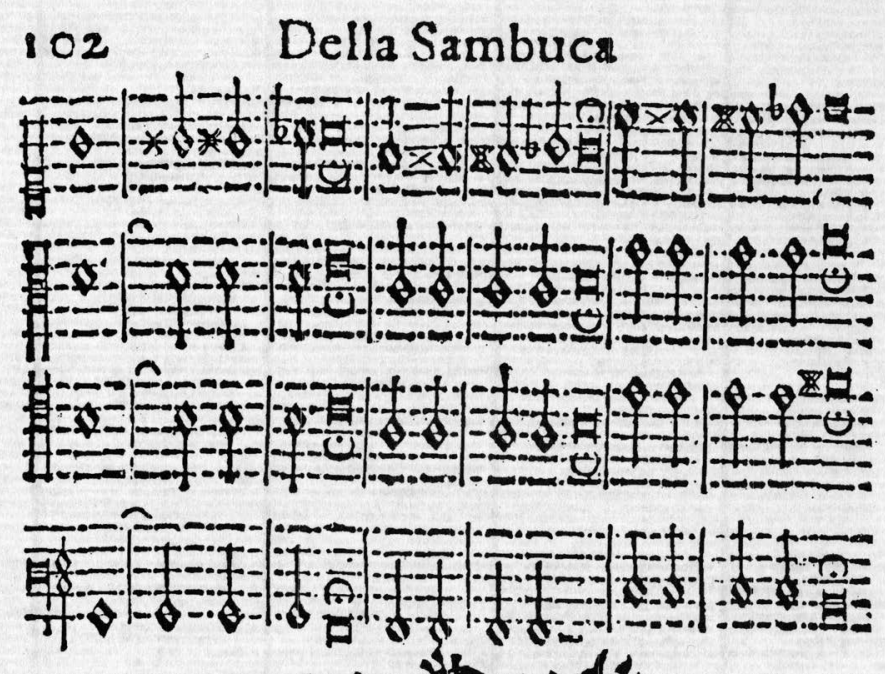


in minute steps; Colonna characterises this as "not dissonant but pleasurable" (ibid., 101-2, my translation; non dissonante anzi diletteuole). The effect could have emerged directly from playing around with the multitonal keyboard; in this context Colonna calls upon "the curious musician" (il curioso musico) to experiment further on his "Istromento perfetto" for the sake of musical enrichment (ibid., 101). ${ }^{19}$ Colonna himself provides an example of this in the form of an "example of the circulation of the enharmonic, chromatic, major semitone, and tone degrees" (ibid., 103, my translation; Esempio della circolatione delli gradi Enarmonici, \& Chromatici, Semituoni maggiori, \& Tuoni)—a fully notated cyclic composition, which modulates through all thirty-one pitches before returning to its starting point (ibid., 103-10). ${ }^{20}$

Strisciare di voce is a well-documented vocal technique; it has since become known as portamento, and is not generally seen as connected with Vieltönigkeit. But we can find an impressive example of just this connection in the works of Domenico Mazzocchi (1592-1665). In his "Lamentum Matris Euryali," for example, the lament of a mother for the heroic but painful death of her son (Mazzocchi 1638, 153-56; see figure 9), ${ }^{21}$ a special symbol (V) in the vocal part indicates that the singer is to perform a specific kind of messa di voce, a "gradual rise in the breath and pitch of the voice, exactly halfway to the aforementioned symbol $x$, as is found in the enharmonic genus" (ibid., 18o, my translation; messa di voce, che è l'andar crescendo à poco à poco la voce di fiato insieme, e di tuono, \& è specie della metà del sopradetto $x$, come si pratica ne gli Enarmonici). The symbol " $x$," which incidentally also appears in the pitches and even figures of the basso continuo, represents the microinterval provided by the vieltöniges keyboard—and Mazzocchi makes explicit mention of these keyboards when he refers to "today's instruments with perfectly split keys" (ibid., 181, my translation; nell'Instrumenti hodierni perfettamente spezzati).

19 "Then the curious musician will be able to practise by means of similar examples, and gain greater profit from study and exercise, and find other beautiful consonances, because these will not be absent on the perfect instrument, with which he can wander through every kind of musical genus, simple and mixed; but thus far it seems better to us that other genera help to enrich Diatonic music, and alter it in time and place" (Colonna 1618, 101, my translation; Potrà dunque il curioso musico esercitarsi da simili esempi proposti, e far con lo studio, \& esercitio maggior profitto, \& trouar delle altre consonanze belle, che non vi ne mancaranno per l'istromento perfetto, con il quale può andar vagando in ogni sorte di geno de musica simplice, \& misto; ma fin hora il seruire delli altri geni per arrichire la musica Diatonica, $\&$ alterarla à tempo, \& luoco ne par miglior).

20 For more on these cyclic compositions, see Rasch (1997-99).

21 For a more detailed discussion, see Kirnbauer (2013, chap. 1). 


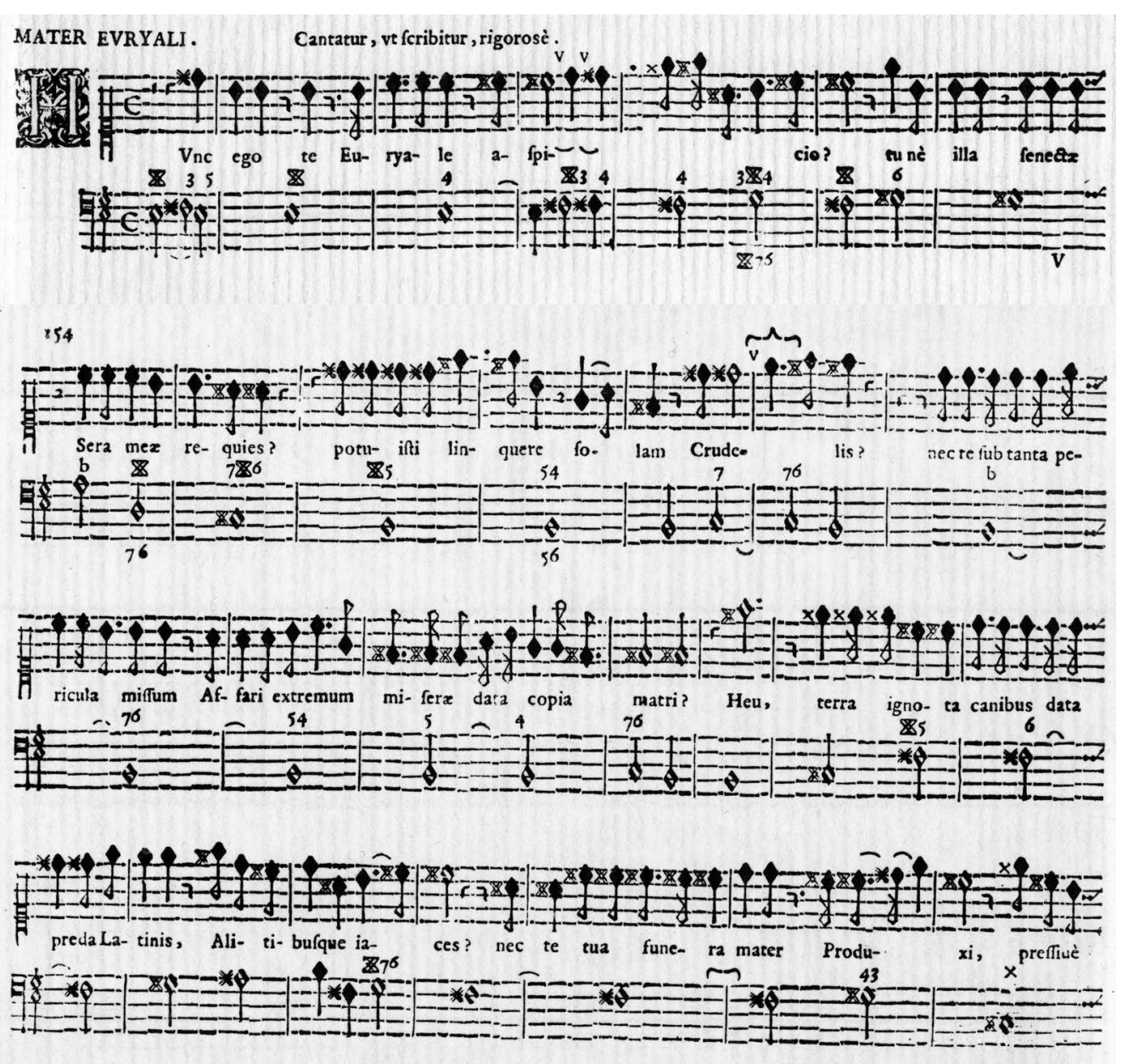

Fig. 9

\section{PER IL CIMBALO CROMATICO-AN “EXTRAVAGANT” SONATA BY GIOANPIETRO DEL BUONO}

Another piece that makes use of the visible and tangible possibilities of a vieltöniges keyboard is Gioanpietro del Buono's "Sonata VII: Stravagante, e per il cimbalo cromatico," published in 1641 in Palermo (del Buono 1641, fol. [M1v-M2v]; figure 10). Each movement in this collection is based upon the cantus firmus Ave maris stella, which the composer uses to demonstrate his contrapuntal skill. In this context, the description stravagante is a keyword: it refers not to extravagance or fantastical eccentricity but rather to a composition with some kind of special melodic, rhythmic, or harmonic feature-in this case, a bold exploration of chromatic and enharmonic effects. The possibilities of the cimbalo cromatico are also fully exploited (with sixteen pitches used in total here, including $\mathrm{E} b$ and $\mathrm{D} \#, \mathrm{~A}$, and $\mathrm{G} \#, \mathrm{C} \#$ and $\mathrm{D} b, \mathrm{~F}$ and $\mathrm{E} \#)$, even though the 

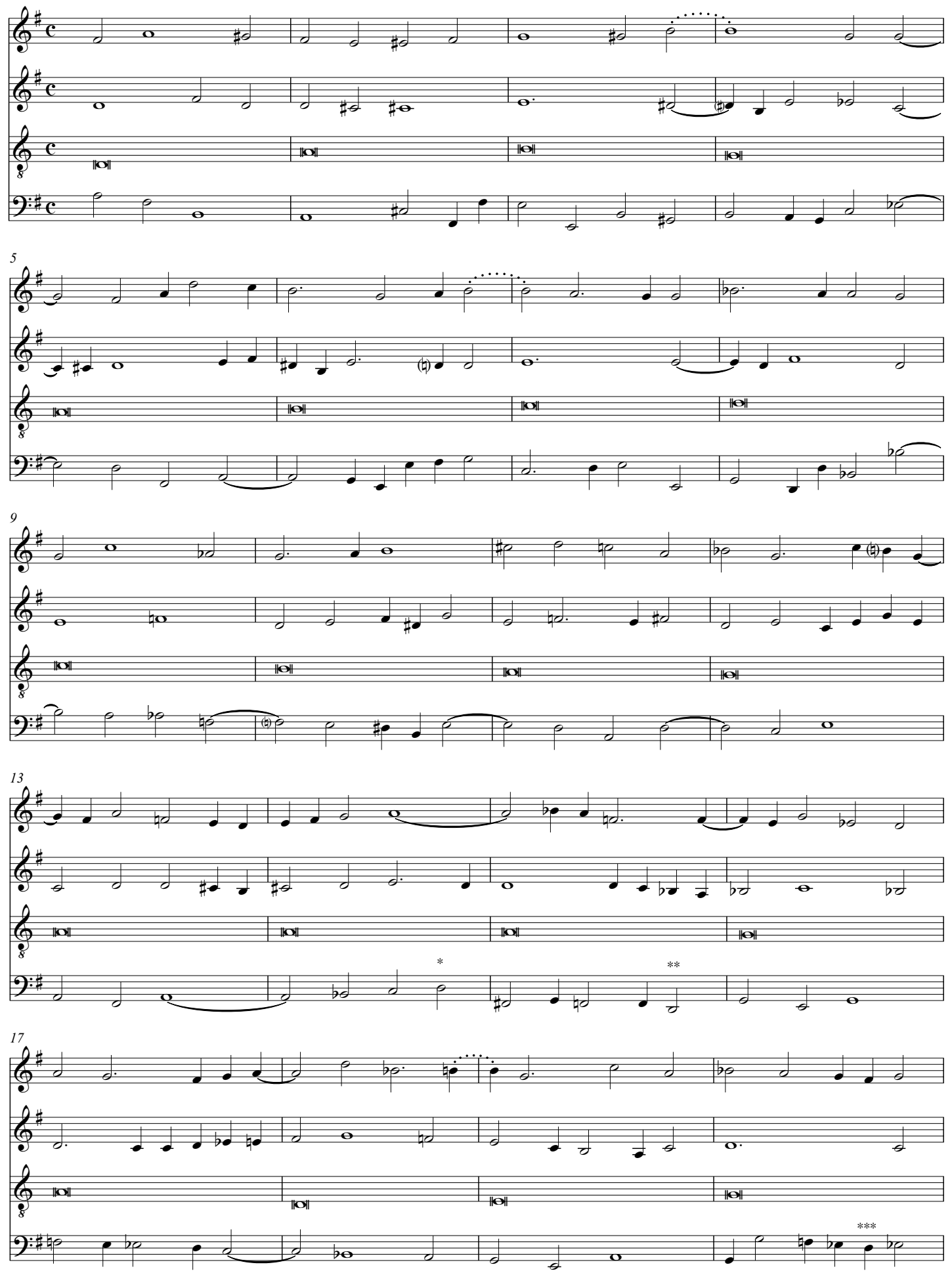

* B M.14,4: written $\mathrm{f}(\#) / * *$ B T.15,5: note missing / *** B M.20,5: written B 

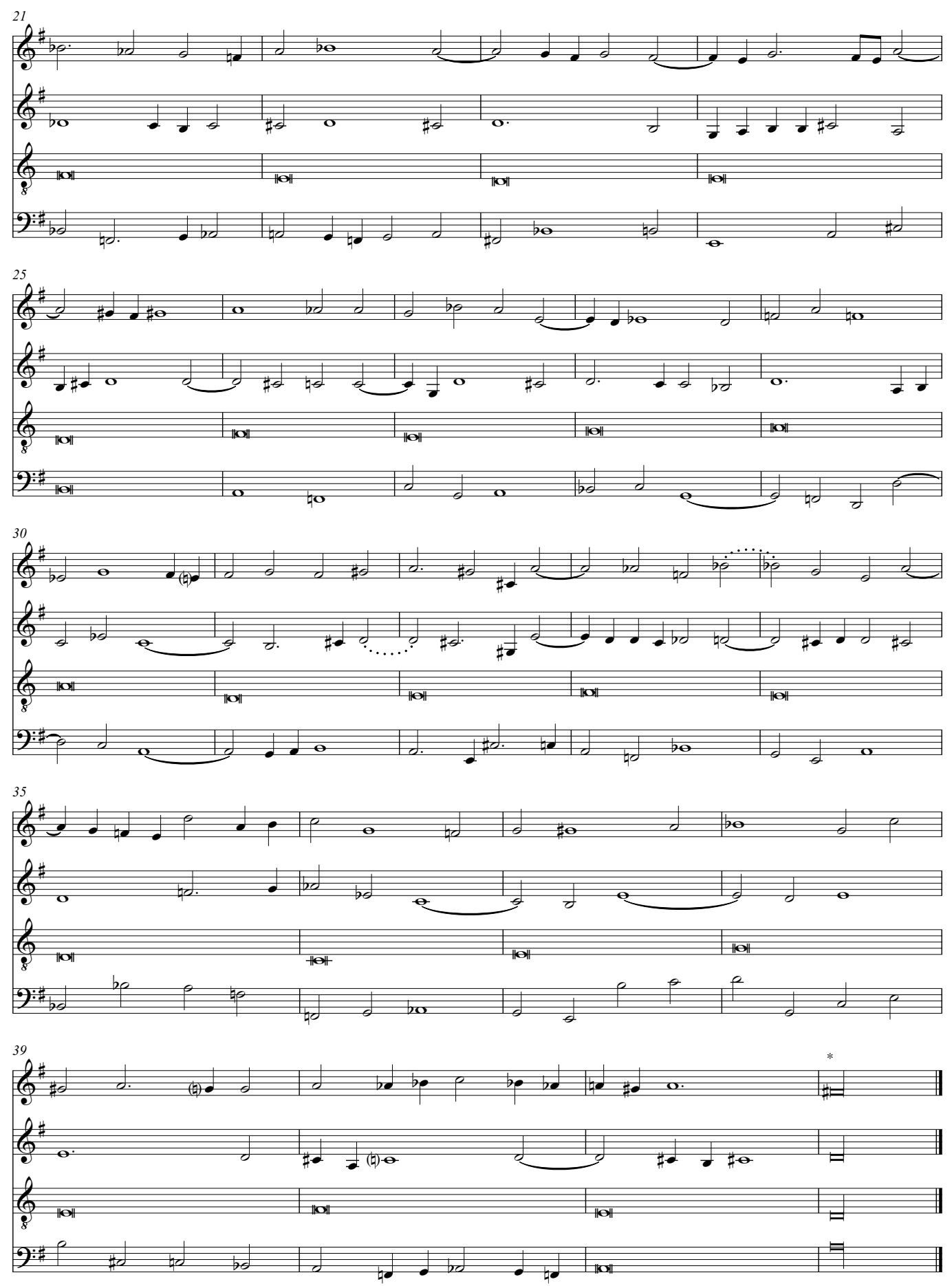

Fig. 10 
cantus firmus actually prevents any distant modulations. Here the vieltöniges keyboard seems to allow new combinations of sounds to spring to the composer's mind. ${ }^{22}$ Even a close analysis of all the false relations, chromatic respellings, and passages of unusual, almost totally free voice-leading with which this piece is peppered would probably still need to fall back upon its basis in instrumental exploration in order to make sense of it.

\section{IN POLYPHONIAM ENARMONICAM-A MOTET BY GALEAZZO SABBATINI}

The same can be supposed of the composition "Derelinquat impius viam suam" by Galeazzo Sabbatini (1597-1662), who had commissioned a vieltöniges harpsichord with thirty-six or thirty-eight notes per octave (Barbieri 1986). ${ }^{23}$ Taking as his starting point a conventionally composed motet with a subtle text, ${ }^{24}$ Sabbatini reworked the piece to produce a vieltönige version, which was published by Athanasius Kircher in his Musurgia universalis $(1650,664-72$ ) as an example of polyphonia enarmonico. ${ }^{25}$ Sabbatini makes use of nineteen pitches in total, each of the seven diatonic notes appearing with accidentals of \# and b (with the exception of $\mathrm{G} b$ and $\mathrm{F} b$ ), and he uses them in a very particular way: not only for "vertical" harmonies and distant modulations but also melodically, as part of the contrapuntal fabric.

Thus we find a rising chromatic passage (figure 11) whose upper voice rises from $E_{1}$ to $G \# 1$ (bar 65 beat 1 ), followed by a cadential step from $G \#$ to $A$ b, which is also indicated in the figures of the basso continuo. This quasi-microtonal progression, which is repeated in other voices between $\mathrm{B}$ and $\mathrm{C} b$ (tenor, bar ${ }_{7} 7$ ) and between $\mathrm{D} \#$ and $\mathrm{E} b$ (alto, bar 69), also serves as evidence that this composition can only be successful if vieltönige scales are observed; a modern reading of these notes as "enharmonically equivalent" would be absurd in the context of this cadential phrase. In the equivalent passages in cantus and alto (bars 65 and 69), the motion of a rising second followed by a falling fifth in the continuo could be regarded as sufficient for a cadential effect, and thus an interpretation of the melodic line as merely an "enharmonic" respelling could perhaps be accepted; in bar 67, however, an insistence upon the same pitch in the tenor over the $\mathrm{E}$ in the continuo would be simply nonsensical in musical terms. This composition, described in Kircher's text as a "prototype," is certainly striking for the consistency with which it explores the possibilities of Vieltönigkeit; but it is by no means unique.

\footnotetext{
22 The recording of the vieltöniges viol consort The Earle His Viols on the CD La Tavola Cromatica provides a good depiction of these new sounds (Tubb and The Earle His Viols 2004).

23 For a more detailed discussion, see also Kirnbauer (2013, chap. 5).

24 "Derelinquat impius viam suam et vir iniquus cogitationes suas / et reveretur ad Dominum et miserebitur eius"- "Let the wicked forsake his way, and the unrighteous man his thoughts / and let him return unto the LoRD, and he will have mercy upon him" (Isaiah $55: 7$ ).

25 See the section marked "Triphonium Diatonico chromatico-enharmonicum"; for a more detailed discussion of the music and its context see Kirnbauer (2013, chap. 5).
} 

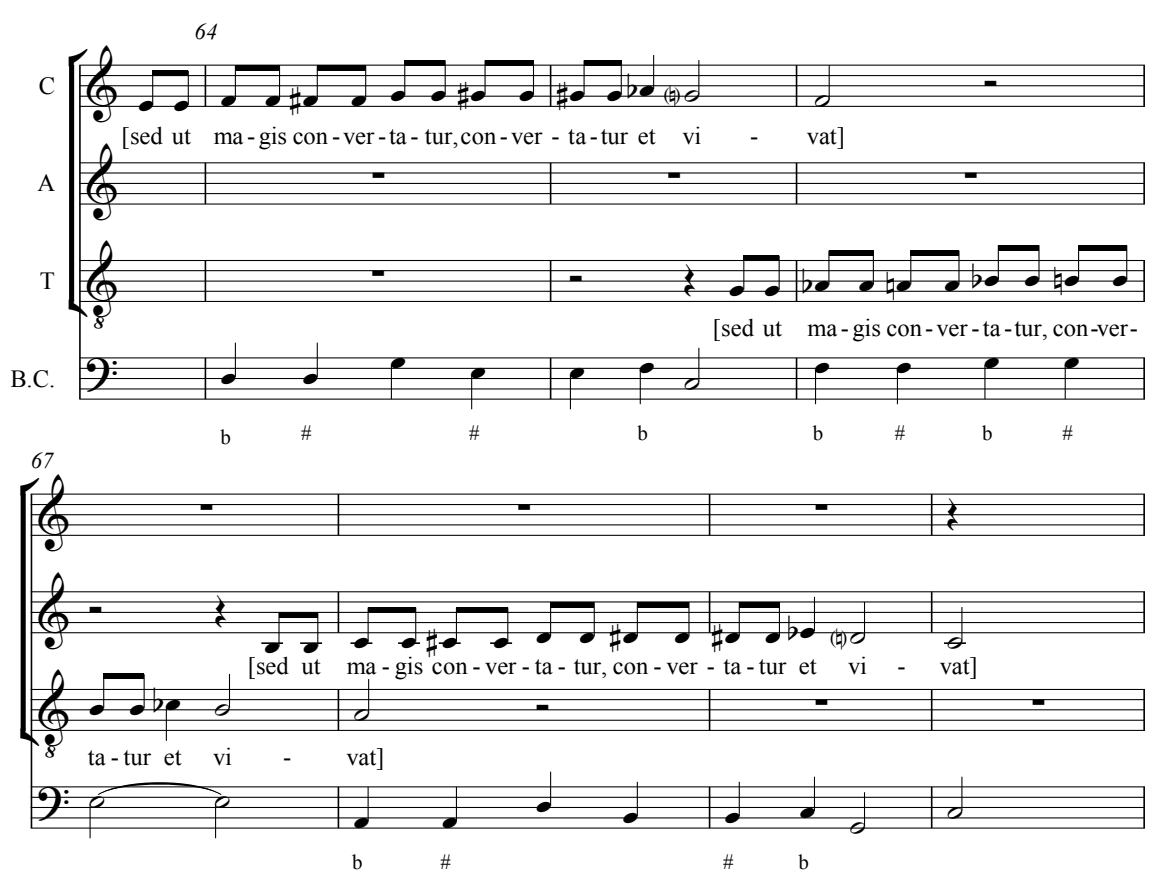

G. Sabbatini, "Derelinquat impius viam suam" (Kircher, Mvsvrgia vniversalis 1650), I 668-9 (T. 63-T. 70)

Fig. 11

\section{MELODIE METABOLICHE-GIOVANNI BATTISTA DONI AND VIELTÖNIGE MUSIC}

The genera, introduced primarily by Nicola Vicentino, were not the only element of ancient music that produced vieltönige results. The principles of the ancient tono $i$ were researched above all by Giovanni Battista Doni (1595-1647) and adapted by him for the musical practice of the period. ${ }^{26}$ Put briefly and in very simple terms, these are based upon octave spans taken from a double octave, each beginning on a different note-in a manner comparable to the church modes, which for a long time were regarded as their descendents, and which carried the same names. Doni realised that each of these scales, with its characteristic (and unequally tempered) sequence of tones and semitones, could be transposed to begin on any other pitch (figure 12). Doni thus makes a distinction between tuono and modo: modo refers to a particular scale with its characteristic sequence of intervals, tuono to its placement in a specific position and the real pitches that result. Each modo can be transposed to another tuono (i.e., another note), resulting in a variety of different scales and different

26 For more detail, see Palisca (1981, 1997); Kirnbauer (2013, chap. 2). 
pitches, since in temperaments such as mean-tone the size of tones and semitones is of course different for each scale. The ability to transpose these scales into the different genera is another, secondary possibility.

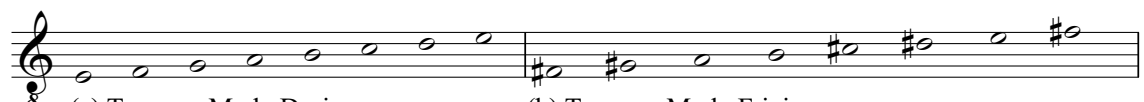

(a) Tuono, e Modo Dorio

(b) Tuono, e Modo Frigio

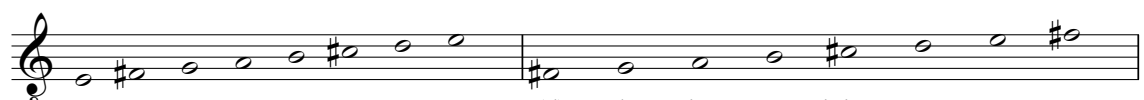

$\begin{array}{ll}\text { (c) Tuono Dorio, Modo Frigio } & \text { (d) Modo Dorio, Tuono Frigio }\end{array}$

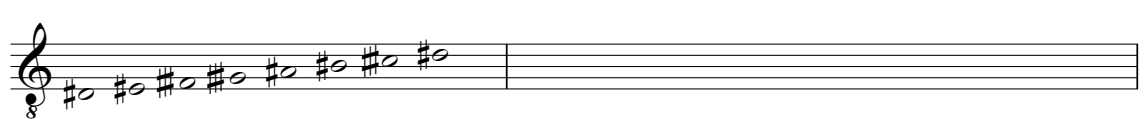

(e) Tuono, e Modo Hypolidio

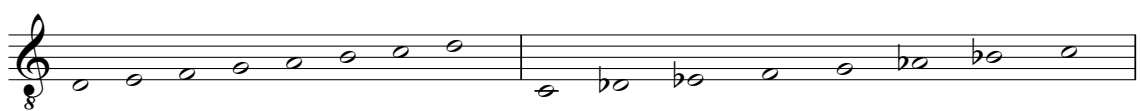

(a) Frigio

(b) Dorio co' segni accidentali
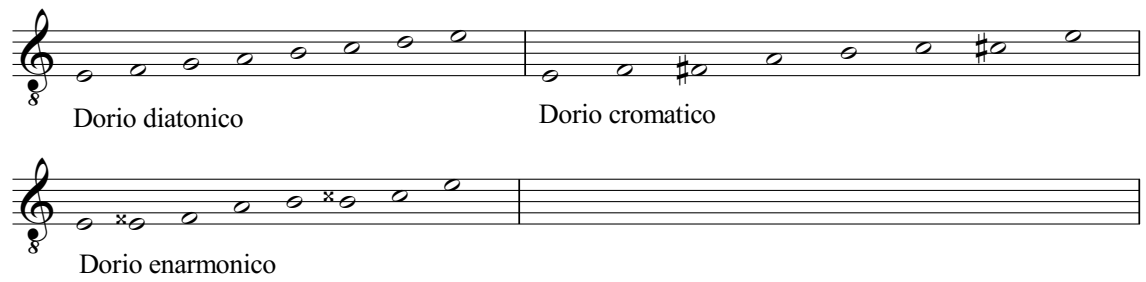

Fig 12

To put his ideas into practice, Doni developed a series of musical instruments: ${ }^{27}$ keyboard instruments with multiple keyboards (one for each tuono), harps with multiple rows of strings, and stringed instruments-especially viols-with separate groups of strings and additional frets for certain pitches. Central is the ability to follow the transpositions of an unequally tuned scale or tonality into distant harmonic areas and the expansion of pitch space that results.

Among the extant compositions following Doni's system is a four-part work for voice with instrumental accompaniment by Pedro Eredia. ${ }^{28}$ It sets a text

27 As well as the aforementioned chapter 2 of Kirnbauer (2013), see also the chapter "Doni's Polyharmonic Instruments and the New Music Inspired by Greek Theory, c.1590-1650" in Barbieri (2008, 221-76).

28 A recording of this work by Eredia (also known as Heredia) can be found on La Tavola Cromatica (Tubb and The Earle His Viols 2004, T18); see also Kirnbauer (2002, 241-43). 
by Maffeo Barberini, Pope Urban VIII, which deals with the fleeting nature of life and the importance of being prepared for the constant possibility of death ("Passa la vita all'abbassar d'un ciglio"- "Life passes in the blink of an eye"). Eredia only uses two tuoni for his setting (Dorian and Phrygian), allocating each to specific passages of the text. This creates a wide-ranging harmonic spectrum (stretching, in modern terms, as far as $\mathrm{F} \#$ major and minor or $\mathrm{C} \#$ major), but with adjacent modal areas juxtaposed relatively abruptly. These distinctions might seem subtle at first, but in the context of mean-tone tuning the tonal differences are considerable and need to be heard anew today.

Shifting explicitly between tuoni was only one way of building on the legendary effetti meravigliosi of ancient music, however. Doni also saw the potential for blending tuoni together, permitting smooth, multi-layered transitions between them. Remarkably, he was also able to integrate pre-existing, apparently conventionally-composed music into his concept-above all a number of madrigals by Carlo Gesualdo with a multitude of $\#$ and $b$ markings, which he described as “"metabolic' melodies, or with a mix of sharps and b flats" (Doni 1640, 302, my translation; melodie Metaboliche, ò variate di diesi \#, \& b. molli). ${ }^{29}$ Gesualdo's music ought in any case to be included in any consideration of different pitch systems, and it also raises the possibility of a clear contemporary solution to the question, heavily debated in the past, of whether Gesualdo's "hyperchromatic," harmonically wide-ranging music was intended for equal-tempered or multitonal tuning. It has now been largely accepted that Gesualdo's own practice was also based around Vieltönigkeit; but it has only recently emerged from an inventory of the Castello di Gesualdo that he himself possessed (and doubtless made use of) a cimbalo cromatico..$^{\circ}$

Alongside keyboard instruments with split sharps, Doni (1763, 1:389, my translation) also specifically describes "normal viols but in a more perfect manner" (Viole comuni più perfette), which are standard viols with added frets, "because these [viols] also normally have a little fret which creates the same effect, without which it is impossible to play the madrigals of Gesualdo well, or similar 'metabolic' melodies" (anch' esso sogliono avere un tastino, che fa l'istesso effetto, ed altrimenti malamente vi si possono suonare i Madrigali del Principe, e simili cantilene Metaboliche). In one of his writings, Doni actually reproduces a madrigal by Gesualdo, "Tu m'uccidi crudele," arranged for an appropriately prepared viol consort. $3^{11}$

Gesualdo's Vieltönigkeit is not only notational but also conceptual, and carries implications for performance practice. Here, an apparently conventionally composed repertoire turns up in a vieltönigen context, with at least some performance situations taking its vieltönige scales into account. Today this idea carries explosive implications for performance practice, but even in Gesualdo's time it had consequences, as composers in Giovanni Battista Doni's time were

\footnotetext{
29 For more detail, see Kirnbauer (2013, chap. 4).

30 "a grand chromatic harpsichord with extended octaves" (Columbro 2008, 182, my translation; un zimbalo grande con le ottave stese cromatiche).

31 A recording can be found on La Tavola Cromatica (Tubb and The Earle His Viols 2004, $\mathrm{T}_{7}$ ).
} 
writing "musiche metaboliche." ${ }^{2}$ The polyphonic madrigal repertoire cultivated by the Roman composers of the seventeenth century is especially relevant in this context. Not only are there examples such as the aforementioned Domenico Mazzocchi's Madrigali a cinque voci, published in 1638 , which features familiar vieltönige elements such as the adapted messa di voce and additional, vieltönige pitches; the interest in polyphonic madrigals actually led to a new kind of repertoire, which could be described as "table madrigals" (madrigali al tavolino). This terminology, first used in about 1650 , can be derived from the visual impression produced by a group of singers gathered around a table, singing madrigals from partbooks. As an image, it is the opposite of a performance al modo d'Orfeo: a solo singer without a score, accompanied only by a basso continuo. Explicit Vieltönigkeit can be found in this repertoire too, even exceptional double-sharps in madrigals by Michelangelo Rossi. Of course, this music can also be played without taking the evidence of its Vieltönigkeit into account, but this overlooks one of the dimensions that it sets up: the effect of a vieltönige performance lies arguably in the excitement of hearing harmonies that have literally never been heard before, far removed from conventional sounds.

\section{SE JOÜE LENTEMENT AVEC DISCRETION-UNDISCOVERED VIELTÖNIGE MUSIC BY JOHANN JACOB FROBERGER AND OTHERS}

The idea, hitherto often overlooked, that a vieltönige performance practice was at least a possibility for this music applies equally to the last examples presented here. These come from a time when it was already becoming ever more normal to use more or less all available pitches (and, before long, all keys), with performance of the resulting music apparently made possible by the temperaments that had been developed by this point. But a closer look at the notation shows that even at this time Vieltönigkeit was (still) clearly extant and practised.

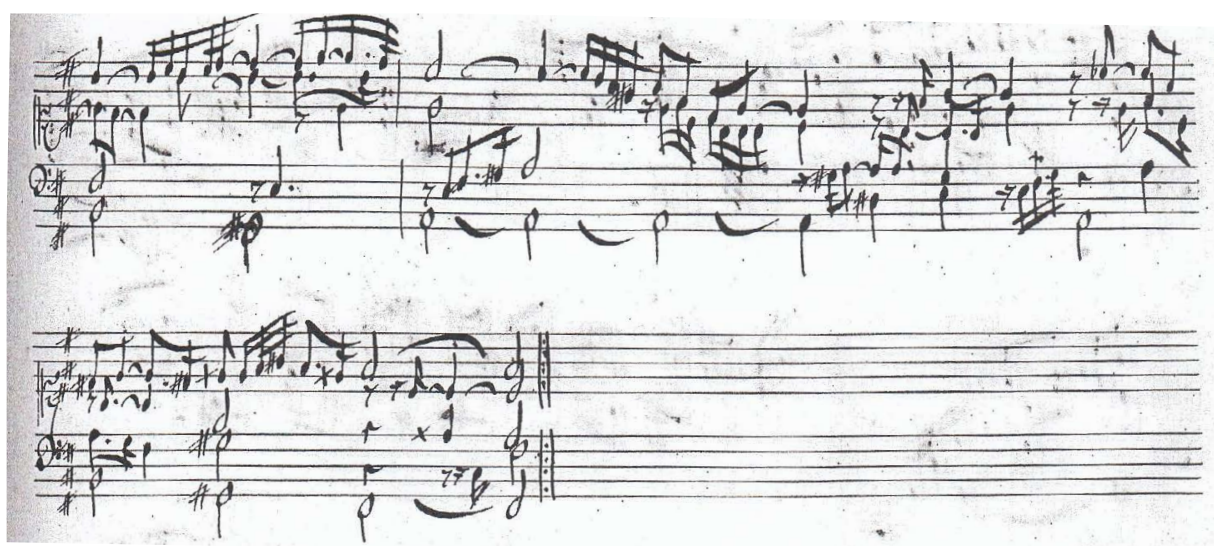


This is evident in the manuscripts of Johann Jacob Froberger (1616-67), where alongside the standard accidentals ( $\#$ and $b$ ) he also uses the sign " $x$ " with the notes $\mathrm{E}, \mathrm{A}$, and $\mathrm{B}$; these are not to be confused with the modern understanding of $\mathrm{E} \#, A \sharp$, or $\mathrm{B} \#$ (figure 13 ). ${ }^{33}$ Froberger is clearly making a distinction here between different pitches within mean-tone temperament-something that would in turn be required for performance by a vieltöniges keyboard instrument. (Just as an aside, it should be noted that all modern editions-and thus far all recordings - of Froberger's music ignore this striking and yet meaningful notational convention). Although this piece can certainly also be played on a completely normal harpsichord, with the usual twelve keys per octave, consideration of Froberger's life suggests a different conclusion. He evidently stayed in Rome several times, having first been sent there in 1637 by the Viennese court to take lessons with Girolamo Frescobaldi; while there he would probably also have become aware of Doni's vieltönige ideas and the music of Mazzocchi and other Roman composers that resulted from them. With this in mind, it seems more likely here that Froberger was writing for a cimbalo cromatico, with a completely different sonic result.

In the case of Froberger, a connection with Roman Vieltönigkeit is possible, and even seems likely. However, there are other examples that are musically very similar (that is to say, vieltönig) but whose background has yet to be investigated in such detail. A violin sonata by Georg Muffat $\left(1653^{-1704}\right)$ can stand as a closing example of this; in some ways it is similar to the piece by Sabbatini discussed earlier (Muffat 1677, corresponding passage on fol. $3^{\mathrm{r}+\mathrm{v} \text {; see figure 14). } 34}$ In total, seventeen pitches are used within the composition, as a result of its far-reaching modulations. A spectacular effect-comparable with Sabbatini's motet - is produced by the direct juxtaposition of $\mathrm{E} \#$ and $\mathrm{F}$ (b. 118), $\mathrm{A} \#$ and $\mathrm{B}$, (b. 123-24), and $B \#$ and C (b. 129-30). In the light of this passage, these pitches demand to be taken seriously as part of a vieltönige performance practice-not only in the violin part but also in the accompaniment of the basso continuo (see Barbieri 2008, 144).35

This brief outline of theory and practice in music that is not "microtonal," but rather "vieltönig," demonstrates that the Vieltönigkeit that I have located in the sixteenth and seventeenth centuries was not only a real phenomenon but also, above all, a musically relevant one-relevant in terms of both compositional structure and performance practice, even for music that appears conventional at first glance. Thus it is clear, too, that Vieltönigkeit was and is no mere theoretical playground but rather (as it were) a musical one.

33 For an example of this, see Froberger $(1660,63)$. This practice, which is not merely a quirk of notation, can also be found in Froberger's autograph manuscripts (Peter Wollny, pers. comm.).

34 One notational quirk should be noted here, the use of a flat sign to cancel sharps and a sharp sign to cancel flats (shown above each relevant note in the transcription).

35 In addition to the sonatas by Marco Uccellini and Alessandro Stradella listed by Barbieri, other similar compositions by Giovanni Antonio Leoni and Giovanni Battista Vitali could be named. 
Sonata Violino Solo (Ausschnitt)

G. Muffat
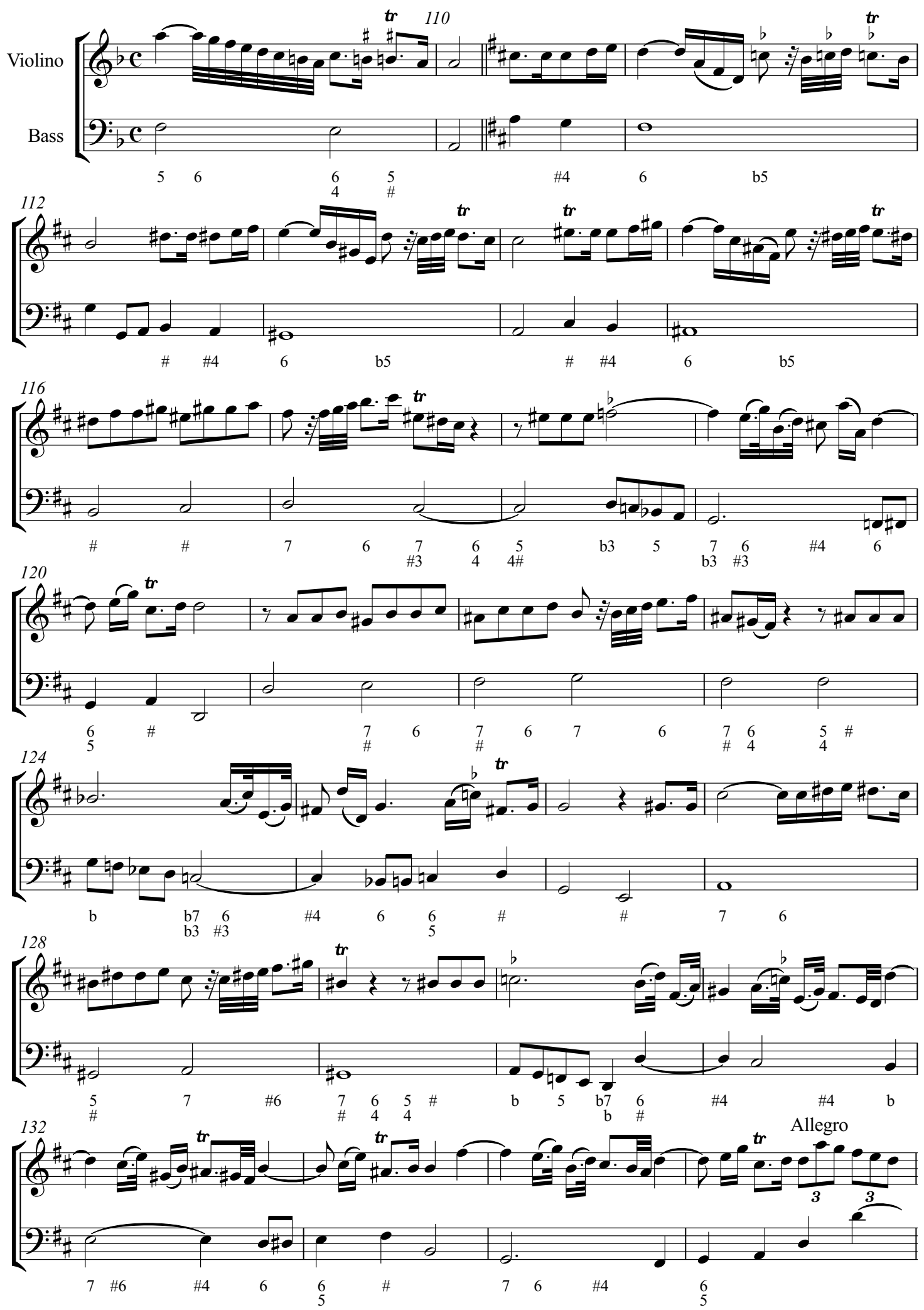

Fig. 14 


\section{REFERENCES}

Barbieri, Patrizio. 1986. "Cembali enarmonici e organi negli scritti di Athanasius Kircher: Con documenti inediti su Galeazzo Sabbatini." In Enciclopedismo in Roma barocca: Athanasius Kircher e il Museo del Collegio Romano, edited by Maristella Casciato, Maria Grazia Ianniello, and Maria Vitale, 111-28. Venice: Marsilio.

- 2008. Enharmonic Instruments and

Music 1470-1900: Revised and Translated Studies. Tastata, Studi e documenti 2. Latina, Italy: Il Levante Libreria Editrice.

Bertrand, Antoine de. 1578. Second livre des amours de P. de Ronsard. Paris: A. Le Roy et R. Ballard.

Colonna, Fabio. 1618. La Sambuca Lincea. Naples: C. Vitale.

Columbro, Marta. 2008. "Il Fondo Gesualdo della Biblioteca Provinciale di Avellino.” In La musica del Principe: Studi e prospettive per Carlo Gesualdo; Convegno Internazionale di Studi, Venosa, Potenza, 17-20 settembre 2003, edited by Luisa Curinga, 171-84. Lucca: Libreria musicale italiana.

Cordes, Manfred. 2007. Nicola Vicentinos Enharmonik: Musik mit 31 Tönen. Graz: Akademische Druck- und Verlagsanstalt.

Del Buono, Gioanpietro. 1641. Canoni, Oblighi et Sonate in varie maniere sopra l'Ave Maris Stella. Palermo: A. Martarello, S. d'Angelo.

Diruta, Girolamo. 1609. Seconda parte del Transilvano: Dialogo diviso in quattro libri. Venice: Vincenti.

Di Veroli, Claudio. 2008. Unequal Temperaments: Theory, History and Practice: Scales, Tuning and Intonation. Bray, Ireland: Bray Baroque. 2nd rev. ed. published 2009, 3 rd rev. ed. published 2013 (Bray, Ireland: Bray Baroque).

Doni, Giovanni Battista. 1640. "Discorso Terzo: Sopra la Diuisione eguale ...” In Annotazioni Sopra il Compendio de' Generi, e de' Modi della Musica, 284-313. Rome: A. Fei.

_——. 1763. "Della disposizione, e facilità delle viole diarmoniche. Discorso qvarto." In Lyra Barberina Amphichordos, 2 vols., 1:376-96. Florence: Caesareis.

Drescher, Thomas, and Martin Kirnbauer, eds. 2002. Chromatische und enharmonische Musik und Musikinstrumente des 16. und 17. Jahrhunderts: Beiträge zu einem Kolloquium der Schola Cantorum Basiliensis, Hochschule für Alte Musik Basel, und des Musikwissenschaftlichen Instituts der Universität Basel am 9. April 2002. Schweizer Jahrbuch für Musikwissenschaft 22. Bern: Peter Lang.

Duffin, Ross W. 2007. How Equal Temperament Ruined Harmony (and Why You Should Care). New York: Norton.

Eck, Cathy van. 2010. "A Good Servant Dismissed for Becoming a Bad Master: Zur Geschichte der gleichstufigen Temperatur." Dissonanz 110: 34-43. Froberger, Johann Jacob. 166o. "Meditation faite sur ma morte future, la quelle Se joüe lentement avec Discretion à Paris, 1 May Anno 166o." Sing-Akademie zu Berlin, manuscript SA 4450, 63.

Griffiths, Paul, Mark Lindley, and Ioannis Zannos. 2001. "Microtone." In The New Grove Dictionary of Music and Musicians, edited by Stanley Saide, 2nd ed., 29 vols., 16:624-25. London: Macmillan.

Haar, James. 1977. "False Relations and Chromaticism in Sixteenth-Century Music." Journal of the American Musicological Society $30(3): 391-418$.

Huber, Klaus. 1999. Umgepflügte Zeit: Schriften und Gespräche. Edited by Max Nyffeler. Edition MusikTexte oo6. Cologne: MusikTexte.

Kircher, Athanasius. 1650. Musurgia universalis sive Ars Magna consoni et dissoni. Rome: F. Corbelletti.

Kirnbauer, Martin. 2002. "'Si possono suonare i Madrigali del Principe': Die Gamben G. B. Donis und chromatischenharmonische Musik in Rom im 17. Jahrhundert." In Drescher and Kirnbauer 2002, 229-50.

———. 2013. Vieltönige Musik: Spielarten chromatischer und enharmonischer Musik in Rom in der ersten Hälfte des 17. Jahrhunderts. Schola Cantorum Basiliensis Scripta 3. Basel: Schwabe. - Forthcoming. “'e potrà facilmente sonare quelle del Chromatico': Das Gambenensemble in Italien und 'vieltönige' Musik.” In Repertoire, Instrumente und Bauweise der Viole da gamba: XXXVIII. Wissenschaftliche Arbeitstagung und 3. Musikinstrumentenbau-Symposium 


\section{Martin Kirnbauer}

Michaelstein, 19. bis 21. November 2010, edited by Christian Philipsen with Monika Lustig and Ute Omonsky. Michaelsteiner Konferenzberichte 8o. Augsburg: Wissner.

Lindley, Mark. 1987. "Stimmung und Temperatur." In Hören, Messen und Rechnen in der frühen Neuzeit, edited by Frieder Zaminer, 109-331. Geschichte der Musiktheorie 6. Darmstadt: Wissenschaftliche Buchgesellschaft.

Lockwood, Lewis. 1957. "Vincenzo Ruffo and Musical Reform after the Council of Trent." Musical Quarterly 43 (1): 342-71.

Mazzocchi, Domenico. 1638. Dialoghi, e Sonetti. Rome: Zanetti.

Muffat, Georg. 1677. "Sonata Violino solo" (signed and dated on the last page “G. Muffat / Pragae 2 Julij 1677”). Musical archive of the Archbishop's Palace in Kroměříž, Czech Republic, shelf mark B IV 118.

Ortgies, Ibo. 2003. "Subsemitones in Organs Built between 1468 and 1721: Introduction and Commentary with an Annotated Catalog." In GOArt Research Reports 3 , edited by Sverker Jullander, 11-74. Gothenburg: Göteborg Organ Art Center, Göteborg University.

Palisca, Claude V. 1981. G. B. Doni's Lyra Barberina: Commentary and Iconographical Study; Facsimile Edition with Critical Notes. Quadrivium 22.2. Bologna: Antiquae Musicae Italicae Studiosi. - 1985. Humanism in Italian Renaissance Musical Thought. New Haven, CT: Yale University Press. -. 1997. "Giovanni Battista Doni's Interpretation of the Greek Modal System." Journal of Musicology 15 (1): 3-18.
Rasch, Rudolf. 1997-99. "The Musical Circle: From Alfonso to Beethoven (I-IV)." Tijdschrift voor Muziektheorie 2 (1997): 1-17, 110-33; 4 (1999): 23-29, 206-13. - 2002. "On Terminology for

Diatonic, Chromatic and Enharmonic Keyboards." In Drescher and Kirnbauer 2002, 21-33.

Tubb, Evelyn (voice), and The Earle His Viols. 2004. La Tavola Cromatica: Un'accademia musicale dal Cardinale Barberini, Roma intorno al 1635. Raumklang, RK 2302, compact disc.

Vicentino, Nicola. 1555. Antica musica ridotta alla moderna prattica. Rome: A. Barre. Translated by Maria Rika Maniates as Vicentino 1996. . 1996. Ancient Music Adapted to Modern Practices. Translated by Maria Rika Maniates. Edited by Claude V. Palisca. New Haven, CT: Yale University Press. First published as Vicentino 1555.

Wild, Jon. 2014. "Genus, Species and Mode in Vicentino's 31-Tone Compositional Theory." Music Theory Online 20 (2). Accessed 12 January 2015. http:// www.mtosmt.org/issues/mto.14.20.2/ mto.14.20.2.wild.html.

Wraight, Denzil. 2002. "The 'Cimbalo cromatico' and Other Italian String Keyboard Instruments with Divided Accidentals." In Drescher and Kirnbauer 2002, 105-36.

Wraight, Denzil, and Christopher Stembridge. 1994. "Italian Split-Keyed Instruments with Fewer than Nineteen Divisions to the Octave." Performance Practice Review 7 (2): 150-81.

Zarlino, Gioseffo. $155^{8}$. Le istitutioni harmoniche. Venice. 


\title{
Inscriptions
}

\section{An Interview with Helmut Lachenmann}

\begin{abstract}
[Musikhochschule Stuttgart]
[This interview was conducted by Paulo de Assis on the morning of Wednesday 4 October 2012 at the Orpheus Institute, as part of the Orpheus Research Festival 2012. Music was heard on recordings or performed live during the course of the interview, as is noted in brackets in the text that follows; video recordings of the live renditions are available at http://www.orpheusinstituut.be/en/experimental-affinities-in-music-repository. The event began with two performances.]
\end{abstract}

[Helmut Lachenmann, Wiegenmusik (composed 1963), performed by Helmut Lachenmann, piano]

[Helmut Lachenmann, Serynade (composed 1997-98), excerpt, performed by Yukiko Sugawara, piano]

ORCiм: We would like to continue with some more music, a short fragment of ". . . zwei Gefuihle ...," Musik mit Leonardo (composed 1991/92), a piece based on a text by Leonardo da Vinci, from which we extracted a sentence that became a kind of motto for this festival. In that sentence, the narrator (apparently Leonardo da Vinci himself) is wandering through southern Italy and approaches a volcano, Stromboli. Seeing a side entry to it in the mountain, he is invaded by two feelings (zwei Gefühle): the fear of going in, of the dangers that are there; but also the desire to enter, and to experience the marvellous things that are inside the volcano.

[Helmut Lachenmann, “... zwei Gefühle ...,” Musik mit Leonardo (composed 1991/92), for speaker and ensemble, beginning, recorded by Ensemble Modern, Peter Eötvös, dir. (see Lachenmann 2002)]

You wrote this piece in the empty summerhouse of Luigi Nono, in Sardinia, shortly after his death. In a certain sense Nono, Leonardo, and yourself(entering Nono's house as Leonardo entered Stromboli) might be thought of as different kinds of "wanderers" in permanent and restless search for the unknown. How do you relate to these two emotions, fear and desire?

DOI http://dx.doi.org/10.11116/9789461661883.cho4 
HELMUT LACHENMANN: First of all, I don't know if Leonardo spoke about himself. If the poet says "I" that doesn't necessarily mean himself. Maybe yes, because in those days to look into nature was not so common. And it [the volcano, and thus the text of the piece] is not only Stromboli, it is "E-"- "Strom-boli""tna"; that means the text is apart from the music, in the sense that I make phonetic elements out of it, and the listener has to work with his memory. Because when I hear "E," that is nothing, it is a stupid phonetic element; but when "-tna" comes, then-“Ah, ha!"-it makes sense. Or: "Scy-"-Wo-" / "la"-"gen" [Scyla Wogen, Scyla waves]; "Cha"-"r"-“ybdis" [Charybdis]. In this way the text is apart, articulating the time.

Secondly, in that moment, I didn't feel myself as a wanderer. I was just a guest in the house of Nono. Somehow he was there, because I saw all his discs, all his things there. For me this piece was ... [very special]. ${ }^{1}$ I know this text by Leonardo very well; he is comparing the eruptions of the volcano and the human heart in search for knowledge- "who we are," "where we are," etc. And then, in the text, in the Codex Arundel, in the British Museum, in the second section, there we have: "Doch ich irre umher, getrieben von meiner brennenden Begierde" [And I wander around, moved by my burning desire ${ }^{2}$ ] to see the wonderful things that the sinnreiche Natur (how much more beautiful is the German language ...), that "the meaningful Nature" has called into being.

Another aspect that might be of interest is the following. I named the piece "zwei Gefühle" because at the end the wanderer-be it Leonardo or someone else in search of his identity, whoever he is, where he is coming from, etc.-he stops in a cavern, and he tries to look in the interior of it, and it is dark. He cannot see into the darkness. And then (und nun), in this moment (later there is a piece of mine to which I gave the title $N U N^{3}$ ), in the feeling of uncertainty (Unwissenheit) there came two feelings (zwei Gefühle). It was I who made the German translation-zwei Gefuihle: Furcht und Verlangen: Fear and Desire. But in the original text from Leonardo, in Italian, which I read much later, it is not due sentimenti (two feelings); it is due cose-two things. And I am angry with that, since my title derives from a not-so-precise translation. [laughs] Anyway ... it is zwei Gefühle. And this fear of darkness, of the threatening darkness of the cavern, and deciding how to see with his own eyes what wonderful [things] might be there ... for me-even if I don't want to become philosophical here-for me it is death. In my opinion (this is very personal) I think art always has to do with death. That means: with life. It's the same. Thinking about death means feeling life.

1 Here, as some other times during this interview, Helmut Lachenmann did not completely finish the sentence. There was a suspension followed by the next sentence. The editor completed this sentence $a d$ sensu.

2 Unless otherwise stated, parenthetical translations are by Paulo de Assis.

3 Lachenmann's NUN (composed 1997-99/2003) for flute, trombone, male voices, and orchestra. 
Continuing with this idea: you wrote this piece after Nono's death. We would like now to go back to your time as a pupil of Nono, in Venice, 1958 to 1960. In several interviews you say that in that period you thought very much about material, you built theoretical speculations, you thought about aesthetic notions and ideas. Later on, with [Karlheinz] Stockhausen in Cologne, and in Ghent (where you made your only electronic piece), you speak about having had the empirical experience of music. All this took place before your definition, let's say, of a personal theory of music material and its apperception. Let's hear the first minute of that piece for electronics.

[listening to the recording] I hate it. It is awful ...

[Helmut Lachenmann, Scenario (composed 1965) for magnetic tape, excerpt]

... a lot of filters and reverberation.

Why do you say it is not a good piece?

I never say "good" or "bad" piece. This was my piece; and in that sense I love it like a child born with defects, which one loves but [which] cannot really live a normal life. So-it is a defective composition. [laughs] But it was necessary. It was a sort of exorcism. And all my students have to go (I was myself there) to IRCAM ... I am not indifferent to this. ... But I developed in a direction where I need the "real" sound in the hall. I have problems with loudspeakers. Even here, when we hear zwei Gefühle [near the beginning of the interview], you don't hear my music-you listen to the membrane of a loudspeaker. And this makes all the noise not anymore dangerous. An electronic sound is not dangerous. But a piece for cello-grrhh [Lachenmann makes a guttural noise with his mouth and nose] - is dangerous. There is something dangerous in the sound. [Coincidentally, at this precise moment cellist Arne Deforce, who would play Pression later during the interview and in the evening concert, entered the room.]

Even with Nono, whose first electronic piece was composed in $1960 \ldots \mathrm{He}$ had no access to the electronic studio before that date... (as long as [Luciano] Berio was the studio's director ....). But Nono (and not only Nono, but the whole of Darmstadt in the 1950s) tried to, again, develop a different way, a new concept of music. The old, traditional concept was not rejected, but it was seen as historic: melody, harmony, rhythm, symphony orchestra, counterpoint, polyphony ... It was not anymore a question of "C major," of consonance or dissonance- a " $\mathrm{C}$ " was not more consonant in $\mathrm{C}$ major than in $\mathrm{Cb}$ or in $\mathrm{C} \#$ major-but it was... "a harp pizzicato," or another pizzicato, or a certain intensity, or a certain duration, or a register, etc. One tried to think in these categories, and Nono was one of the most strict [of the] persons doing this.

I think I was Nono's only pupil in those days. I was a kind of Versuchskanninchen [a guinea pig]; he tried out how to teach. Whenever I wrote two notes, one after the other for the same instrument-let's say for an oboe a C\# and then an Eb with a legato slur-he said, "This is a melodic element, this is bourgeois, you should never do this!" And this was hard. If I wrote a trill, he would say, "You are 


\section{An Interview with Helmut Lachenmann}

François Couperin, with all these ornaments ...” After six weeks (I was coming every week) I stopped. Some weeks later I came back and he said that if you wrote only one note, let's say for harp, it was already a bourgeois element. This was my way to find his ideas...

These were very important provocations for me, so I had to think about other categories. Music is already a complex of categories, and the composer is like someone at a driving school gaining new licenses in how to drive. He has to construct his own behaviour. And he has to find it for each new piece again and again. And this is not in the electronic medium (which is a kind of "paradise"), but in society's material. So I wrote pieces for orchestra; I wanted to go directly to where our bourgeois categories are working and "not to do" something there. This was somehow the idea. So I owe a lot to Nono, to his "paralysing" me. I was paralysed, and I had to fight against this paralysis. And this gives a lot of energy - to do things that are not accepted immediately, but which are logical.

I have another thing to say (excuse me, if this is too long an answer) which was for me very important. Nono (this is my theory) was living in a city where there was no sound. He could not hear any of his music. He was sitting in the Giudecca, and his "inner ear" was not so prepared as the ear of [Pierre] Boulez or Berio or Stockhausen (who had always ensembles and electronics around him). So what Nono wrote was always with very homogeneous elements: he wrote a piece for six sopranos and a solo soprano, ${ }^{4}$ or he made a piece like Cori $d i$ Didone 5 for eight sopranos, eight altos, eight tenors, eight basses, eight cymbals, and four tam-tams. And then the compositional way was [like this]: the second tam-tam together with the tenors one and four, or two tam-tams together only with the first soprano ... He made a game of combinations, undoubtedly rich, and the first person who was shocked by the result was Nono himself. He could only listen to it in Cologne, and it was new to him. The other composers ... more or less, they knew already what they did. And I, I needed to hear what I was writing, so I had to go away from Venice. So after two years I went-and Nono was very angry at me when I went- to Cologne, to the Kölnische Musikschule, where there was Stockhausen, whom I already knew from Darmstadt. He made the piece Plus-Minus. ${ }^{6}$ We got seven sheets of paper with material and symbolic things, materials with which we had to make a piece for ... [an ensemble]-I made a piece for strings and percussion, others made pieces for recorders, for choir and tam-tam, another person made a piece for seven marimbas, etc. It was always made with the categories of Stockhausen's rule, which was the beautiful element of this Fibonacci series $(1-2-3-5-8-13-21$, etc.), and we had to speculate if a sound would be hard or soft, with or without resonance, etc.

In the same course there was another teacher: Henri Pousseur. And he was as important as Stockhausen. We were twelve composers in the room, and

\footnotetext{
4 Nono's "Ha venido"-Canciones para Silvia (composed 1960) for soprano and six-voice choir (sopranos), after a poem by Antonio Machado.

5 Nono's Cori di Didone from La terra promessa by Giuseppe Ungaretti (composed 1958), for choir and percussion.

6 Stockhausen's Plus-Minus (composed 1963), $2 \times 7$ pages for realisation.
} 
Pousseur came in, and he asked me to tell him a sound which came to my mind in that precise moment. I said, "a whistle." He looked at another student and asked for another sound. And he said, "the beginning of Beethoven's Ninth Symphony." Pousseur then asked for one hour of silence in which each of the students had to find a scale which brings the whistle on the one end to the beginning of the Ninth Symphony on the other end. So we had to think: how can we find steps which bring us (like a scale on a keyboard) from this sound to this experience? The wonderful thing is that after one hour all the twelve composers had a totally different scale. One made something based on memory, another on more acoustic materials, etc. This was a way to have imaginationand not to be happy about imagination, but to be concerned about bringing it now into a special context. This was very important to me. Then the idea of authenticity, of innovation, was not anymore to make a botanical [exotic] sound of whatever timbres. It was not yet the time of Tactil,7 the music of [Mauricio] Kagel. At that time there was the music of [John] Cage and of Michael von Biel, who made an incredible string quartet [Lachenmann produces a guttural noise through the nose] with just always alienated sounds, ${ }^{8}$ and my own music. The idea was not to find always "another" sound, but to bring a sound into a context that was totally new. This was the point.

And in order to find these new contexts you developed (starting in 1968-69) an enormous reflection upon what it is to compose, what are the conditions of the music material... You made a typology of sounds...

Yes.

... which you could apply to all music from all times...

More or less...

You give examples of some passages from Chopin...

Yes.

So, in parallel to your more purely artistic practice there was a huge theoretical reflection being made by you. In my view your music is a clear example of a continuum between reflection and praxis-whereas for some other composers there is no relation between what they say and their music. This was the time when you composed pieces like Pression,9 which we could hear now...

Arne! Now is your turn.

7 Kagel's Tactil (composed 1970) for three performers.

8 Lachenmann is probably alluding to Michael van Biel's String Quartet No. 2 (composed 1963).

9 Lachenmann's Pression (composed 1969, notation revised 2010) for solo cello. 
My question is very simple: did you feel the need for a precise reflection or did this reflection emerge, so to say, naturally?

No, no. You must not forget that this was the time of the student revolts. A time at which, well ... I knew very well the so-called terrorist Gudrun Ensslin [194077] from the RAF [Rote Armee Fraktion]. I did not have contact with her in that time, but I was interested in her destiny, in her being in jail, etc. And there was a student protest against the indifference in society-indifference in relation to what was happening in Vietnam, in the third world, while there were orgies of consumerism. There was a philosopher-Herbert Marcuse-who spoke about Konsumverweigerung [anti-consumerism]. And in those days I spoke about what nobody - composers - liked to speak about: about beauty. I said that "beauty is the denial of habitude." It is maybe a little bit einseitig [partial, one-sided]; it's not perfect. But it was a sort of... an occasion to think about beauty. Everybody knew what beauty was. It had, more or less, a gastronomic aspect. Digestible must be beautiful... Anyway, in those days composers were asked: are you only intellectual or surrealistic, spiced for this culture or a little bit provocative ...? In that context I wanted to have a sound situation which was totally clear, not a structural process but a sound as the result of its production. This is something we have in the music of Pierre Schaeffer, but it is all recorded: we hear a locomotive sound, a water drop, things that have to be recorded and that will come out again from the loudspeaker.

And then there was a composer like Kagel, and I think he was one of the first to make musique concrète: he made a sound where we hear not only the sound, we hear how it is made, the resistance of the material, which is tortured or corporeal. Corporeal, for me, was essential. I studied a lot of symphonic musicthe timpano in Beethoven's Piano Concerto No. 3, for example, is a kind of alienated pizzicato; or eight horns in a Bruckner symphony is like a huge lung. There are a lot of elements. I always remember-I studied Hector Berlioz's instrumentation treatise in the revision by Richard Strauss (Berlioz and Strauss, 1905) - the overture King Lear from Berlioz, which ends with a very high pizzicato. Strauss writes that it looks like if in the head of the crazy king there is a vein bursting. This way of corporal listening (and not: "this is G major" or so), this was extremely important for me.

In the first pieces, at that time, I tried just to make studies. For Pression, which we shall now hear, I was invited by Siegfried Palm to make a study. (Bernd Alois Zimmermann made three pieces. ${ }^{10}$ ) Pression ... Well, the titles already give you information. Yesterday we heard tem $A,{ }^{11}$ which is Atem, to breathe, and we hear the voice of a female singer, not the "soul" but more like an instrument, like a machine: aah, ohh ... I don't know which feelings these are, they are instrumental challenges. And this was also done with instruments that are not anymore "philharmonically beautiful" but seen as sources for producing sounds-

10 Reference to Zimmermann's Vier kurze Studien (composed 1970) for solo cello.

11 An excerpt from Lachenmann's temA (composed 1968) for flute, voice (mezzo-soprano), and cello, which had been performed by the soprano Linda Hirst on the previous day of the Orpheus Festival. 
of which we had yesterday a lot of wonderful examples. I try to create always a new context. Let's hear a section of Pression.

[Lachenmann's Pression (composed 1969; see Lachenmann 1972, 6-7, the section called "snoring"), played by Arne Deforce, cello]

\section{This music also suggests new modes of listening. What is listening for you?}

Well, it's clear that our "old” antennae don't help. But the piece helps us know which antenna one needs to understand it. But the question of listening ... Sometimes I am asked about how one should listen; or, some other times, I have to make an introduction before a certain piece is played. I would like to take the risk to say that there is a collective precondition in an audience. If they are listening to what happens at the level of melody or so, then there is nothing, or there is not enough, it is strange ... It is an invitation to hear the real, corporal elements of the sounds. And this is, let's say ... empty. I sometimes say that composers are total parasites: a composer did not invent a cello, he uses it; he has never built a harp, a harpsichord, or a piano, he uses them; he has never invented a string quartet, nor an orchestra, nor an organ. He saw these wonderful sounds, elements, or instruments, and then he uses them. His problem is how to make "his" instrument. Therefore, I like very much the title of Morton Feldman's piece The Viola in My Life. ${ }^{12}$ [Pression] was "the cello in my life." Now, almost fifty years after, the cello is probably another instrument in my life.

But to think about this body and to make a new context - not just only to show things on the instrument, but to show a context ... I asked Arne to play this part of the piece because there are two opposite situations, which are the same; they are opposites and they are the same. They are the same in the sense of being extreme: maximal pressure, to be done in a beautiful way-this is beautiful! It is maybe barbaric, but that's also part of culture. This maximum of pressure also makes the instrument happy. And the other extreme is to have an aural, beautifully played $\mathrm{D}$, in this case on two strings, a sort of Bebung [tone beats]. These two different situations belong together. One is the brother of the other. And in the sense of pressure, if the bow is going along inside the bridge, we hear a sort of fortissimo non possibile. He gives all his energy in ... [Lachenmann produces breath noises simulating this passage] There is an ambivalence: we hear a piano, but it has an intensity of fortissimo. This is also a certain idea of "family." By the way, I like the idea of "family," like I saw it in Henri Pousseur's lesson: to bring elements into a context. And then it is not such a problem to find new sounds, but then to find not only one family but many families (a sound might have a relation to other families) ... and such pressure also has a frequency. So there is pressure, there is an intensity, there is a crescendo, there is a sort of perforation. The ambivalence of different, in this case acoustic, characteristics

12 Feldman gave four works this title: The Viola in My Life I (composed 1970) for solo viola, flute, violin cello, piano, and percussion; The Viola in My Life II (composed 1970) for solo viola, flute, clarinet, celesta, and percussion; The Viola in My Life III (composed 1970) for viola and piano; and The Viola in My Life IV (composed 1971) for viola and orchestra. 


\section{An Interview with Helmut Lachenmann}

brings out a sort of organism together. This was a study in order to make an almost traditional, quasi-symphonic [laughs] context: it starts pianissimo, then there is a kind of crescendo until the ... [Lachenmann makes noises imitating the music] I could be talking about a Bruckner symphony, starting pianissimo and then making a huge crescendo. It has a directional tendency-but at the same time there are other elements with a more "constellation" force. This is a little bit the way of thinking in this composition.

But I don't forget that this is a violoncello; this is important. Very often musicians in the orchestras, in the 196os, they hated me totally: "I studied fifteen years my beautiful instrument and you make me take the bow and play grhhhgh, which is not beautiful and is not what I have studied, and [which] everybody could do." So I had to think about this and then they asked me, "Why don't you do this with electronic means? No one will blame you for that." And my answer was, "No, you should hear not only what it is but also what it was and what it could be, all those qualities around, of which some I can control; others I cannot control myself, they come by themselves. They are the result of my so-called fantasy, or my so-called speculation, or my so-called reflection about what it was and what it could be." This is a complex ... [process] for the audience. Let me say this: each of us has his own personal structure (like Woyzeck said, "Manchmal hat man so ein Charakter, so eine Struktur ..." ${ }^{3}$ ). Part of this structure is collectively preformed-maybe in the Western tradition through tonality. We are born and grow up with this. Then there is the special structure of our personal experience, and this structure comes in friction with the structure of a piece. What we hear is this friction. It might be sympathetic, because we know it from before or we like it. Our nervous system and our memory also react and what happens in this encounter between our structure and the structure of a piece (which has symphonic sources, like a piece for cello or a piece for orchestra), what really happens (and this is now objective), beyond what the audience says in terms of "I like it!" or "I hate it!", which is not so important, what happens is...

Well, I make this difference in listening (Zuhören): in this moment you are in a process of "zuhören." You hear what I say; I could speak like this [very low-register voice] or like this [very high-register voice] and that would make no difference, you are not giving attention to my acoustics, to my phonetics. But if I do something like this [Lachenmann starts intonating his speech, quasi-singing] then you begin to listen, you move from zuhören to hören, to perceive what is in here. And one starts finding things that were not provided to be seen: "I perceive something." I think Schoenberg never spoke about perception, about listening. And I would like to call this a game. As I am a totally Eurocentric person, [laughs] I think that our listening or perception is "reflected." Even when we are disturbed or irritated by something, we begin to think. And this thinking I call in German Beobachtung, to observe. I suggest to the audience (it seems

13 In Georg Büchner's Woyzeck, Woyzeck, speaking to the doctor says, "Seh'n Sie, Herr Doctor, manchmal hat man so 'n'en Charakter, so 'n'e Struktur” (Büchner 1879, 177, as translated in Büchner 1971, 115; But doctor, some people are built that way. It's in their character). 
the best way to establish contact), I suggest not to listen with their old way but rather to observe what happens. This is what you do in everyday life. If I want to know a person, his character, I don't ask him "what is your hobby?" or "are you happy?", or so on. No, I observe him. I observe him when he is angry, when he is serene, when he is in traffic, when he is reading, etc. Observing is a way to better understand a thing. I like (I am a utopian), I like to think of a civilisation in which going to a concert is an adventure of observing.

So, what did you observe last evening in our Kagel concert? ?14 $^{14}$

Oh, I observed lots of things! But not only “observing." I think that was a joy for the festival - and not only joy, it was also full of impact. And I observed myself too. This is important: "What happens with me?" So, for instance ... (well, you are very indiscrete with me [laughs])... I was totally happy, it was one of the best performances of Kagel (for me, in my limited experience). For instance, and this is my professional deformation, I heard always "ostinato." There was always some effect which was in some way repeated. Changed but always repeated. Pizzicato on the string, then a whistling there ... and this was similar in both pieces [Tactil and Unter Strom ${ }^{15}$ ], a different way of enjoying a situation. But technically speaking, as a composer, I hear an ostinato. A kind of "ostinatoid" music (ostinatoid? ... a new word ...). I also observed the big silence or the big time, which is a free time; there is no rhythm. My music always has a limit, I always make rhythmical things. [laughs] And there were also lots of indirect quotations, especially in Tactil. So there are lots of things to discover, to learn, to observe and to think about-especially to think about in relation to our way of listening to music like that of Kagel.

We are almost at the end of this talk, but I still have two topics that I would like to cover. One has to do with the act of writing. You speak a lot about that, about notation, about the inscription. There are two things about which we would appreciate having your feedback. First thing: as far as I know you still have the habit of copying, with your hand, scores from other composers. And the other thing is that (I remember you told this to me) while composing, in the moment of composing, of notating things into the score, you make noises with your body, with your tongue, with your nose. So, apparently there is here something in which, in the precise moment of notating, of making the inscription, something very particular happens. (I don't remember having heard about another living composer who copies scores from other composers.) It's as if there is some kind of more corporeal relation to notation itself, to the physical act of notating. If I think about Boulez or [Brian] Ferneyhough ... well, I don't know, but I don't think they do this kind of thing. What I know is that you do.

14 The opening concert of the Orpheus Festival 2012, at the Minardschouwburg on 3 October 2012, in which Mauricio Kagel's Tactil (composed 1970) and Unter Strom (composed 1969) were performed by Luk Vaes (piano and direction) and Seth Josel and Jona Kesteleyn (guitars). Video excerpts are available at http://prod.orpheus.marlon.be/en/projects/reconstructing-kagel\#media.

15 Kagel's Unter Strom (composed 1969) for three performers. 
Well, it's for me ... This is very difficult, it is very private. When I was young I did not understand the music of Alban Berg, nor the music of Schoenberg or Webern. I didn't even understand the texts of Adorno. And I didn't understand Hyperion by Hölderlin. And so I made a "Flucht nach vorne" ["pressing forward"]: I copied it. I copied (in handwriting) Hölderlin's Hyperion, I copied some texts by Adorno, I copied L'existentialisme est un humanisme [Existentialism and Humanism] by Sartre, and a couple of other things. I also copied the Kammerkonzert by Berg. For me, this copying is like a therapy. In writing a score I take each note into my hand in a specific moment. And as I have ugly writing, in that moment it must be as clear and as beautiful as possible. This helps me. I think slower and I feel slower, and my fantasy comes out.

As for the other topic, I cannot really confirm. My writing ... I don't know ... Once I wrote a piece with the title Schreiben ${ }^{16}$ [writing] because I saw a film that totally touched me. I don't remember the director; it was a German film about Mozart made in the time of the War, a film six hours in duration or so. ${ }^{17}$ There is a scene where you see Mozart as a young man in a hotel in Italy, on his way to Rome, and he had to write a recitativo for his opera Lucio Silla. And we only see a wall clock, [Lachenmann replicates the sound of the beating clock: tick-tock-tick-tock] then we listen to some noises, [Lachenmann produces noisy scratches on the table, like hands touching and writing on sheets of paper] and then we know that Mozart is writing his recitativo! This was really important for me. There is a noise ... a friction again, a friction between some material and another material.

Anyway, I would like to say something without being asked for-related to this "observing." I think we should also know that the situation in which we are rests on people that are [psychologically] "conditioned." We are in a time where cultures come closer together. And in this situation (as I told you before) I have a big problem in Germany. Not as a composer only, but as a citizen. What we call "art" ... People speak about "Japanese art," about "Indian art," about "European art," as if you could take out the word "art" and bring them all together. But the Indian art or the Asian art-be it Japanese, Chinese, Korean, or Indonesian - all is ritual. For instance, in music, there is no music which we have to hear. There is no music we have to sit down and listen to. Music is not there to be listened to. Music is there to be sung, to be danced, to pray to the gods, to conjure something, etc. It has a religious, a ritual function. And this is everywhere, even in our Western civilization. I think that a Gregorian chant was not there to be listened to-it was a way to get closer to the numinous, to God. And then there came one guy, maybe on the organ, and he added a second note to the monophony. People thought "What happened?"-and they started making things, they started thinking about and feeling the need to notate them. I don't know of any other culture which has the idea of dissonance. It doesn't exist. Why dissonance? It is an element of opening, always opening, opening, and opening. We have a tradition of always opening our material, our aesthetic experience, and of irritating society. At the same time we have another culture,

16 Lachenmann's Schreiben (composed 2003/4), for orchestra.

17 Lachenmann may be recalling Mozart: Aufzeichnungen einer Jugend by Klaus Kirschner (1975), although misremembering certain details. 
because in the subscription concert series people don't go to the concert to open up their horizon, they go to confirm their horizon. And this is a problem.

Another important thing is that Western tradition (which I love) is also problematic due to this permanent "searching for something." There is one element about which we are totally envious of other cultures: they are "intact." So we invite Indian musicians, and they play here, and we are fascinated. We are not fascinated because we know this culture, but because we don't know this culture. It has an exotic effect, sometimes even a "touristic" effect. I know that the big master Ligeti invited some aborigines to dance at the Berlin Philharmonie. And these poor guys, half naked—and it was not Tactil [laughs] — had to dance, had to make their ritual dances for a paying audience. So we are fascinated by exploring other cultures (Mozart's Alla turca is another example). This is a little bit of a problem because we have this tradition of exploring other cultures and that creates an obstacle to really understand those other cultures. You are fascinated by the aesthetic elements without understanding what is happening. On the one hand we should keep our tradition, in the sense of always opening; and, on the other hand, we should see the limits to it. If it is just the use of other cultures it is, for me, mainly entertainment.

So, to finish maybe in an adventurous mode and taking some risks, I think we should try a definition of what one could call "art." If you really succeed in defining art, you are lost, and you are in the presence of a definition. I will start with "magic"-philosophers might find this problematic. Magic means: all together we are dominated by a collective power. This is magic. It has a ritual function. But in our Western society, since Illuminism, there is no intact religion anymore. So we have a surrogate for magic.

One of my daughters went to a techno party-this was magic. This was commercial (we could buy a ticket), there was a little bit of LSD and Ecstasy, and people feel happy being there together. They are not there to listen to anything, but to be together. Others go to the Festival of Salzburg to do the same thing. Or to Bayreuth. They go and buy magic in the place of our lost magic. And coming back to what we call art: art is not magic, art is what I call reflected magic, that means broken magic. And this broken aspect reminds us that we have a brain, some kind of machine here that reflects and that has the advantage to constantly open up the horizon.

And we should all work in order to create in the audience this idea of "adventure" in the concert hall. It begins with magic. Think of the beginning of the Eb-Major Symphony by Bruckner [No. 4], with the pianissimo and tremolo: it's a magic moment. The hall is full of $\mathrm{E} b$ major, in tremolo and pianissimo. But then it goes on ... Or the beginning of Wagner's Rheingold: five minutes of $\mathrm{E} b$... It's a harmony which Wagner didn't invent. He found it. He is a parasite as well! But he made something out of it. And this way of reflecting the elements and giving them a new context is always a sort of irritation and we should welcome such an irritation. And the audiences today should finally welcome such irritations and not protest against irritation. [laughs] This is your ... [responsibility]. You have to do this. 
A last question would be related again to Nono, but also to John Cage, especially because these composers have been relevant to the Orpheus Research Centre in the last years. And also Nono and Cage were or still are important composers for you, as you told me in previous talks.

Yes.

You say they are Hoffnungsträger (carriers of hope).

You know that I once was a ghostwriter for Nono in an article against Cage-or, more or less against the epigones of Cage, against "chance" (as an element of invention), which was seen as "impotent." (Once I was talking to Stockhausen and he said that Cage is "an organised impotence." And I said to him, "But your music is organised potency, so it is the same neurotic situation!") Anyway, this way of not anymore making decisions is a tradition-because the so-called individual "I" went through a big crisis in the beginning of the twentieth century, when it was, or still was, idealistic.... But then came Georg Büchner and said "Der Mensch ist ein Abgrund," 18 and then came Sigmund Freud and Karl Marx, and a composer like Schoenberg who gave the authority to the row. And then came a composer like Berg ... And his most expressive moments are marked "Ausdruckslos" (without expression). And the serial thinking after the [Second World] War is a moment where the so-called "I" gave his authority to the so-called structure, or algorithm. And this was the way of Nono: decision, not of the "I," but of some other authority, in his case of serial procedures (which he later opened again). Cage came to Darmstadt ... . well, I already knew him since 1954, when I was eighteen years old and thought the world was finished . . . In $195^{8}$ he came to Darmstadt and he made . . . a big mess, that's what he made. Thirty points on a page, and he made a pentagram. ... It's finally music not full of stupid, personal speculations. It's empty. And this idea of emptiness came to Cage maybe from his Zen thinking. And empty, well ... In Stuttgart there was a painter-Willi Baumeister-who said: "Ich bin ein Leerer" (with two e's), which means "I am" ... not "a teacher" (Lehrer) but "an empty maker" [from Leer, empty]. Because the students were so full of so many things, all the conventions, and to "find" themselves they have to first "empty" themselves. This was Cage. He was an incredible example, a great paradise of finally "listening" and not of speculating, not "what he wants," or so ... And Nono was totally against this attitude. He said this was imperialistic. This was a small story, because later they became good friends. Cage never spoke any critical word about Nono; he had great respect for him. Nono was not so nice. He was doctrinaire.

18 From scene 11 of Büchner's Woyzeck: "Der Mensch ist ein Abgrund, es schwindelt Einem, wenn man hinunterschaut ... Mich schwindelt ...” (Büchner 1879, 184, as translated in Büchner 1971, 120; Every man is a bottomless pit; you get dizzy when you look down). 
When I was his ghostwriter Nono came to my house and told me, "You have to write this and this ...," and so on.... Among other things he talked about Venetian pirates, who went to the Near East and to Egypt, who destroyed the temples there, took the stones and made with them a special wall in the Basilica of San Marco. For Nono this was imperialist thinking. Like Cage's use of other culture's materials. This was in 1959. Then I had big problems with Nono, and we had twelve years without any contact. I did not want anymore to be controlled by him. But later, in 1986, Nono sent me a note about that wall in San Marco, how wonderful it was, how many different structures and cultures coming together... [laughs] So Nono was not changing, but he was opening again.

For me ... Cage ... It was, as you see ... For Nono, the elements he worked with were not limited but . . He came from his Italian tradition, from the Renaissance, etc. He almost never wrote really alienations. A little bit in La lon$\operatorname{tananza}^{19} \ldots$, in the tapes. But this is ridiculous ... I don't find it interesting...

[Salvatore] Sciarrino brings it out in his recording with Melise Mellinger (Nono 2000)...

Yes, yes ... Well, this was the world ... For me the incredible thing is that Nono, writing two notes ..., these two notes, maybe a fifth ... I never heard such fifths before ... So incredibly intense. The same thing, I remember, are the fifths in Beethoven's Ninth Symphony, but that is another thing. And Cage, I think he has a lot of traditions. I want to say-well, it sounds a bit disrespectful, but it is not-Cage is labelled a "composer," but Cage made arrangements: arrangements of situations. Also Mahler made arrangements. Think about the third movement of the First Symphony, the "Frère Jacques." He stole the melody, he stole the accompaniment, he stole the timpani, he stole the double bass and he made a thing ... not a composition.... And the Boléro by Ravel, it's also an arrangement-totally full of spirit. And the idea of composing like this, going beyond a situation is very helpful to thinking. And Cage has this spirit, and he is a gigantic composer. We can find our own structural elements in this. But I'm a European. It is not the end of composing. And Cage is not anarchic at all. Anarchic is something for bourgeois people, they like anarchism. One likes bungee jumping and all kind of strange things, and one likes anarchism too. Cage is a very strong composer; but still, with his entire incredible world, he is a master of the arrangement. I would like to begin there, and then to make out of these wonderful elements, which are empty now, to fill them again with other ideas. So, this is my relation [to Cage], and I think this was also the relation (friends and counterparts) between Cage and Nono.

19 Nono's La lontananza nostalgica utopica futura. Madrigale per piú “caminantes" con Gidon Kremer (composed 1988/1989) for solo violin and eight magnetic tapes. 


\section{An Interview with Helmut Lachenmann}

REFERENCES

Berlioz, Hector, and Richard Strauss. 1905. Instrumentationslehre. Enlarged and revised by Richard Strauss. 2 vols. Leipzig: C. F. Peters. Berlioz's treatise first published 1844 as Grand traité d'instrumentation et d'orchestration modernes (Paris: Schonenberger). Strauss's revised edition translated by Theodore Front as Treatise on Instrumentation (New York: E. F. Kalmus, 1948).

Büchner, Georg. 1879. Wozzek: Ein TrauerspielFragment. In Georg Büchner's Sämmtliche Werke und handschriftlicher Nachlaß, edited by Karl Emil Franzos, 161-201. Frankfurt am Main: J. D. Sauerländer's Verlag. Büchner's play written 1836-37. Translated by Victor Price as Büchner 1971.

. 1971. Woyzeck. In The Plays of Georg Büchner, translated by Victor Price,

105-32. London: Oxford University Press.
First published as Büchner 1879 .

Kirschner, Klaus. 1976. Mozart: Aufzeichnungen einer Jugend. Munich: Bayerischer Rundfunk. Released with English subtitles as Mozart: A Childhood Chronicle (New York: Kino Video).

Lachenmann, Helmut. 1972. Pression: für einen Cellisten. Wiesbaden: Breitkopf \& Hartel. Revised 2010 (Wiesbaden: Breitkopf \& Hartel). Citations refer to 1st ed. —. 2002. “... zwei Gefüle ...,” Musik mit Leonardo for speaker and ensemble. On Helmut Lachenmann: Schwankungen am Rand, performed by Ensemble Modern and Peter Eötvös (dir.). ECM New Series, ECM 1789461 949-2, compact disc.

Nono, Luigi. 200o. La lontananza nostalgica utopica futura. Performed by Melise Mellinger (violin) and Salvatore Sciarrino (sound projection). Kairos, 0012102KAI, compact disc. 


\title{
Nuance and Innovation in Part I of the " 48 "
}

\author{
Mark Lindley \\ University of Hyderabad
}

This essay offers some addenda, based mostly on my findings as described and illustrated at www.SIM.spk-berlin.de (Lindley 2012), to the information in David Ledbetter's splendid book Bach's Well-tempered Clavier: The 48 Preludes and Fugues (2002). Page numbers will refer to his book unless another publication is indicated. For efficiency I will call him "David" and will use the abbreviation WTC for Part I of the 48. When I refer to "the nuanced tuning" I will mean the style of temperament that I have argued (at the SIM website and elsewhere ${ }^{1}$ ) that Bach had in mind for WTC. When I refer to "the tessitura," I will mean the forty-nine-note range (from low to high C) of the music in both parts of the 48 . My preliminary remarks will include three points (tagged with bold numbers) supplementing David's characteristically fascinating account (104-11) of the historical context of the idea of composing a set of pieces in twenty-four keys. ${ }^{2}$

(1) There had been a venerable tradition, in certain rudimentary genres of liturgical music, of covering all the church modes. The most obvious example is, in the Liber usualis, the eight tones of the psalms for ordinary chants of the office (cantus ordinarii officii). In sixteenth-century polyphony, the eight church "tones" (two with D as the finalis, two with E, two with F, and two with $\mathrm{G}$ ) were accommodated by mean-tone temperament on organs with the most routine set of twelve pitch classes (forming a chain of fifths from $\mathrm{E} b$ to $\mathrm{G} \#$ and therefore, in mean-tone temperament, with neither $\mathrm{A}$ b nor $\mathrm{D} \#)$ as long as $\mathrm{V}$-I cadences were not required in the Phrygian mode (E minor) and as long as the Dorian, with its often flattened sixth degree, was not transposed more than one place down in the chain of fifths to $\mathrm{G}$ minor. In that context a locus classicus that covers the eight tones is Andrea Gabrieli's set of organ intonazioni published at Venice in 1593. But of course those little pieces were intended merely to preface other music in services of worship, whereas the WTC preludes are so substantial, and individually so interesting as coherent musical structures, that it seems only natural that Chopin would in due time compose a set of twenty-four preludes

\footnotetext{
DOI http://dx.doi.org/10.11116/9789461661883.cho5

1 For example, Lindley (1987a, 1997). Lindley and Ortgies (2006) may also be of interest.

2 During his two presentations at the Orpheus Academy 2011, several music examples were played on the harpsichord. These can be heard online at http://www.orpheusinstituut.be/en/experimentalaffinities-in-music-repository
} 
each of which introduces only ... another prelude. To compare the set of WTC preludes and the set in Chopin's Opus 28 would take me off topic; but let me, having thus evoked the overarching similarity, say that (2) the innovation of devising the WTC set was a good deal greater than the sum of the innovations ("Erfindungsvolle ... Gedanken" and "sonderbaren Vollkommenheiten") 3 in the individual pieces.

According to Christoph Wolff (2000, 230), "More than any other of Bach's works composed before 1722 , the preludes and fugues of The Well-Tempered Clavier manifest his resolve to leave nothing untried, even if it meant exploring avenues where no one had gone before." I don't know all of Bach's and everyone else's compositions from before 1722 well enough to judge whether every feature of the individual WTC pieces that seems likely to have been novel was really unprecedented, so I will offer mere suggestions that this or that feature may have been novel.

In doing so, I will try to assume now and then the point of view of an imaginary music student of that day. A composer who was one of my teachers fifty years ago, Leo Kraft, used to speak of a distinction between "norms," "procedures," and "operations." A "normal" feature is one the absence of which might cause someone to call the music abnormal. (Tonality was such a feature in the eighteenth century.) Apprentices traditionally learnt certain technical "procedures" (such as fugato, canon, the dance forms, etc.) that they would then (according to this terminology) be free to use or not to use in this or that composition. "Operations" are, on the contrary, freshly devised. The borders between these three categories of technical features are fuzzy. For instance: a composer might copy an operation from another composer (or from another piece of his own), and if this kind of thing goes on for a while, it becomes a procedure; and the history of genres would include descriptions of procedures becoming norms. But even so, the concept seems to me useful for pondering innovation in WTC without getting bogged down in historical fine points.

Having mentioned the old set of eight church modes or "tones," I should mention also the sixteenth- and seventeenth-century increase in the number of church tones, which was, as everyone knows, followed in the eighteenth century by a reduction in the number of everyday modes to two or three (the third one being Phrygian, as for instance in some of Bach's settings of "O Haupt voll Blut und Wunden" and "Herzlich tut mich verlangen") and by an expansion of the number of keys. Notation-wise there were, as David points out, more

3 "very inventive [musical] thoughts"; "notable perfections." These phrases are from the obituary published originally in 1754 (Schulze 1972, 87) and Johann Abraham Birnbaum's defence of Bach in 1739 (Neumann and Schulze 1969, 349).

4 A warning for impressionable students: while Wolff (2000) provides a very rich survey of biographical information, his analytical insights into music are of uneven quality. Some examples of ineptitude in regard to WTC are his statement that Bach "set the stage [for certain later historical developments] by exploiting fully the chromatic and enharmonic potential of the keys" (ibid., 230, my italics), his confusion of "the premise [allegedly in WTC] of equal temperament" with the use by Bach of "a slightly modified system of tuning ... enabling him to play in all twenty-four keys without losing the characteristic features of individual keys" (ibid., 228), and his precept that a triad is a key in its simplest form. (In common-practice music there is no such thing as a key without a leading tone making a tritone with another note in the same diatonic scale.) 
than twenty-four keys already in Bach's day, but acoustically only twenty-four on normal keyboard instruments, and it is in keeping with this reckoning that WTC Prelude 8 is notated with flats (in $\mathrm{E} b$ minor) and yet Fugue 8 with sharps (in $\mathrm{D} \sharp$ minor).

David mentions the concept of "transposed modes." (F\# minor, for instance, was often, though not always, transposed Phrygian.) In my opinion, the evidence for which is set out elsewhere (e.g., Lindley 1987b, 268-69), (3) Bach was probably stimulated to compose WTC by Johann Mattheson's favourable Refléxions ... (1720) on an anonymous essay in an eminent Jesuit intellectual journal (1718), according to which the nuances of unequal temperament were the main reason why contemporary composers sometimes preferred "transposed modes" to the older, "natural" ones. 5

David's many interesting remarks-which can readily be surveyed via the index to his book-in regard to the ritornello principle (which I take to be that of stating the opening thematic material in different keys at different moments in the composition) do not take full account of the following point made by Andrea Werckmeister (1697, Register and 33, my translation) in 1697 in regard to an unequal temperament of his own design but relevant also to the somewhat more subtly unequal style of temperament that I believe Bach had in mind twenty-five years later:

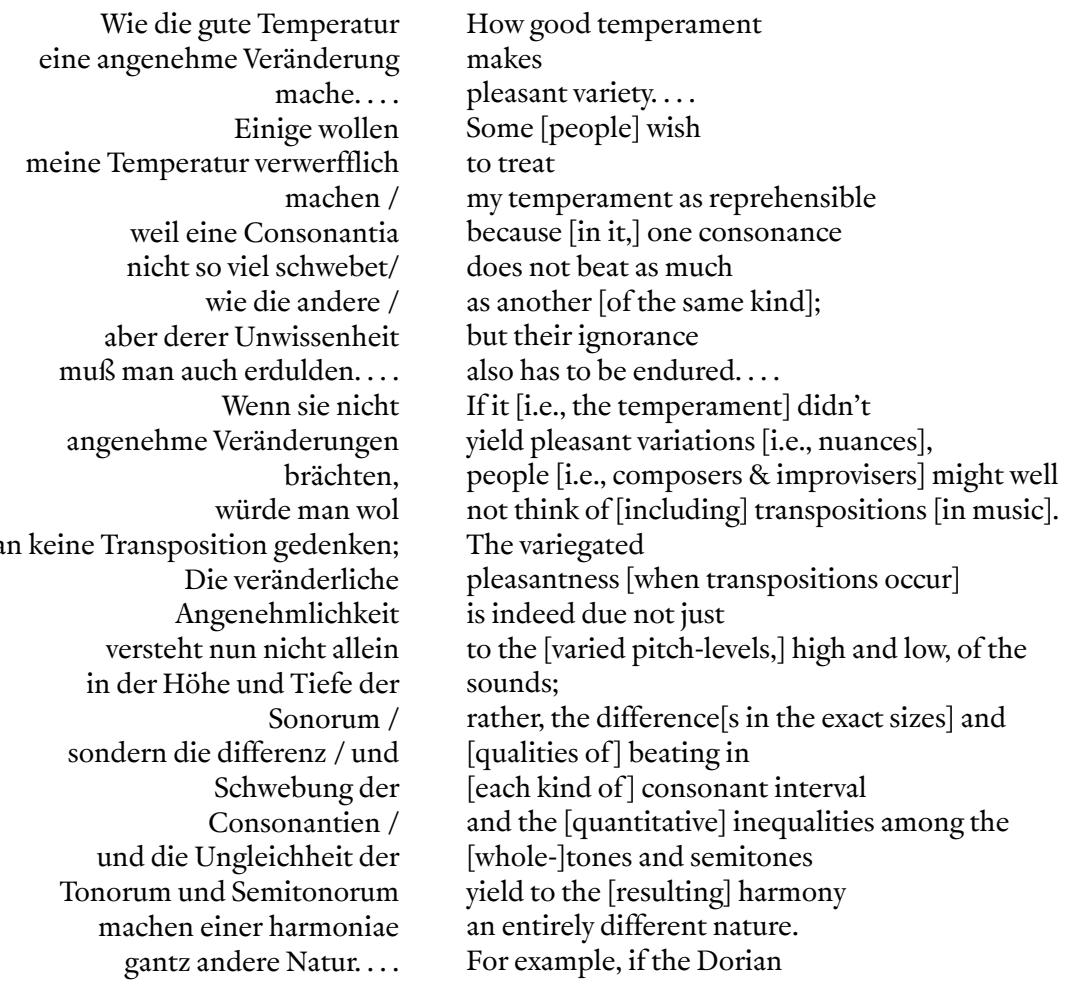

5 "[P]ourquoi l'on employe quelquefois dans la composition, les tons ou modes transposez [i.e., transposés] preferablement aux tons ou modes naturels." See apropos Lindley (1987b, 230-32, 267-69). 


\section{Mark Lindley}

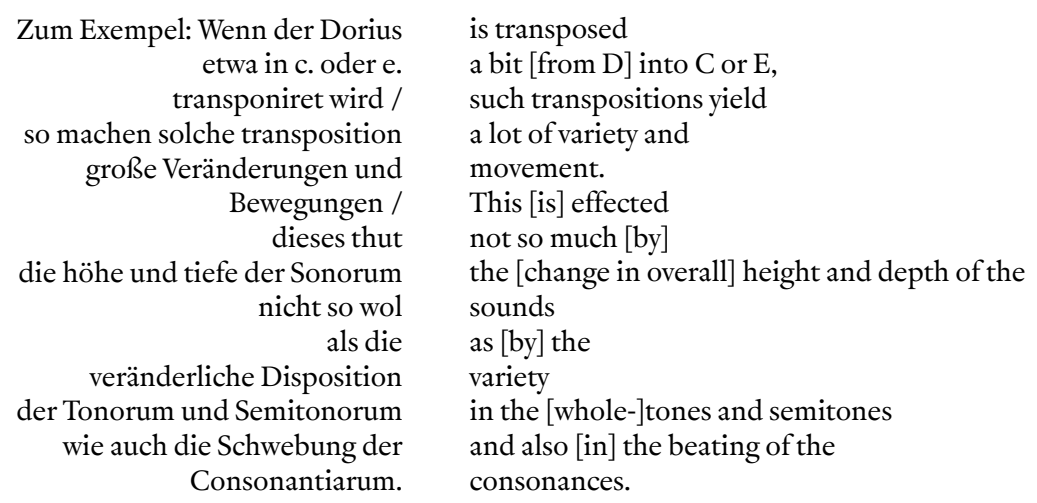

Let us turn now to the preludes and fugues.

In the nuanced tuning, the "childlike" affect of the first four bars of the C-major prelude is well served by the moderate tempering of the C-major triad; and the gentle mood in the next fourteen bars is served by the well paced introduction of gradually smaller semitones: $\mathrm{F} \#-\mathrm{G}$ in bars $6-7$ and $10-11, \mathrm{~B} b-\mathrm{A}$ and $\mathrm{C} \#-\mathrm{D}$ in bars 12-13, and $A b-G$ in bars 14-15. The salient diminished third in bars 22-23 (the chiaroscuro aspect of which is stronger in the nuanced tuning than in equal temperament) moves the affect beyond the confines of "childhood innocence" and thereby strengthens the effect of the pedal point in the following eight bars. ${ }^{6}$

The phrase structure is more complex than one would expect in a "childlike" piece. My thoughts about it are as follows. In bars 6-19 there are macrorhythmic strong-weak pairings of the bars owing to an alternation between relatively dissonant and relatively consonant chords. And since the suspension in bar 6 is prepared in the previous bar, that bar-bar 5 -is best taken as macrorhythmically weak rather than as the strong beginning of a four-bar phrase (pace Gounod). After the strong-weak pairings in bars 6-19, there is no such alternation in bars $20-23$, since 21 has a saliently dissonant suspension prepared in 20 ; so 20 is, like 5 , best taken as being the last in a set of five bars, and 21 as the first of a set of three. Bars 24-33 are again characterised by strong-weak pairings; but then to treat $34-35$ likewise would render the final bar weak even though it is clearly the concluding point of arrival in the piece (containing, according to Heinrich Schenker, the last note of an Urlinie ${ }^{7}$ ); it is therefore preferable to

6 An example, encountered by many children taking piano lessons, of a passage in the parallel minor that does not disturb the sunny overall mood of the piece is the phrase in $\mathrm{C}$ minor that serves as development in the first movement of Clementi's C-major Sonatina.

7 See the first graph in Schenker's FünfUrlinie-Tafeln (1932). Schenker regarded the first three bars as part of a Dehnung whereby bars $1-4$ are somehow equivalent to the first bar in a four-bar group. I regard bars 4-7 as a four-bar group and bars 1-3 as a three-bar group on its own. From bar 2 onward, I hear each bar as representing one macrorhythmic beat, strong or weak (as the case may be) in keeping with the venerable concept (set out, for instance, in Book III of Zarlino's Istitutione harmoniche, 1558) that suspensions are to occur on strong beats and to be prepared and resolved on weak ones; in bar 1, however, I take the first half as a macrorhythmically-strong entire beat but the second half as a macrorhythmically weak one in which middle $\mathrm{C}$ is prepared to be suspended on the next strong beat. This interpretation obliges me to suppose that the macrorhythmic beats start out in bar 1 as half bars but then suddenly become whole bars since the fact that the notes in the second half of each bar are the same as in the first 
treat $32-34$ as a phrase of three bars, whereby bar 34 , with its $\mathrm{V}^{7}$ over a pedal-point $\mathrm{C}$ in the bass, becomes a gentle anacrusis (calling for rubato) to bar 35 .

The quasi-thematic material of bars 1-4 is, nevertheless, evoked in bars 8-11 and $16-19$ as well as $32-35$. Bars $8-11$ amount to a ritornello-like evocation in $G$ (the key of the dominant) of the initial thematic material; whereas 16-19 stand in, though in another way, for a subsequent ritornello in the subdominant key. This is more subtle and "adult" than, for instance, C. P. E. Bach's use of the ritornello principle in his famous C-minor Solfeggietto. ${ }^{8}$

Our imaginary student of Bach's day, having thus had some hints that the preludes were going to amount to a maturation of the genre, would find some novelties in the $\mathbf{C}$-major fugue as well, notwithstanding that the theme is so "innocent" and poised that it could serve in a mere organ verse. The qualities of innocence and quasi-ecclesiastical poise are well served by the nuanced tuning, in which the tempering of the $\mathrm{C}$-major diatonic scale is more like a mean-tone temperament than is that of any other diatonic scale. Some obvious novelties are: (a) in bars 1-6 to present subject-answer-answer-subject rather than subject-answer-subject-answer, 9 (b) to end at the top of the tessitura, and (c) in the final version of the piece (as revised in the 1730s) to use thirty-second notes in the subject (instead of sixteenth notes as in the original version of 1722).

The aura of innovation is then heightened, it seems to me, by the rather close parallel between the chords in the first eight bars of the $\mathbf{C}$-minor prelude and of the C-major one (as if Bach were showing how to use similar chord progressions at the outset of pieces expressing very different affects). It is also enhanced by the fact that bars 8-11 show how a series of 9-10-9-10 suspensions and resolutions between the top and bottom lines can be extended to yield a modulation to the relative major instead of to the dominant, as in the $\mathrm{C}$-major prelude. In the nuanced tuning, the sweetness of the modulation to $\mathrm{E} b$ is augmented by the low intonation of the $\mathrm{A} b \mathrm{~s}$ in bar 10-whereas the low intonation of the $A b s$ and $E b s$ in bars 1- 5 had strengthened the sense of minormode darkness. Later on, when the $\mathrm{D} b$ in bar 36 has added a further touch of such strength, the acoustic clarity (I am tempted to call it luminosity) and sense of ease of the much less heavily tempered final $\mathrm{E}$ t is all the more telling. Let me mention also how well suited the moderate tempering of $\mathrm{F} \#$ (in relation to $\mathrm{D}$ and $\mathrm{A}$ ) is to the relatively gentle quality of bar 6 vis-à-vis the greater sense of stress in bar 5 .

half is a novelty in bar 1 but not thereafter. I regard bar 3 as macrorhythmically weak, notwithstanding the (compound) diminished fifth between $\mathrm{B}$ and $\mathrm{F}$; I regard that $\mathrm{B}$ as a resolution of the dissonant $\mathrm{C}$ in bar 2. Music theorists ever since Artusi (1589) had allowed for dissonant fourths to be resolved in such a way; and some eighteenth-century theorists admitted septimal consonances, such as F may be said to become in bar 3. (Mozart appears to have treated as such the same high $\mathrm{F}$ in the second half of bar 4 of the Jupiter Symphony.) According to David (155), “Schenker's perception of the C major prelude as a series of four-bar phrases seems to impose a Classical model on a structure more fluid and varied than he allows for." I too see many four-bar phrases in this piece, but not at the outset (and not at certain moments later).

8 Dreyfus (1996) includes informative analyses of some of J.S. Bach's adaptations of the ritornello principle.

9 The normal procedure in fugues was to alternate, at the outset, between statements of the subject and of the answer. 
David points out $\left(153^{-55}\right)$ that in the $\mathbf{C}$-minor fugue the material in triple counterpoint functions as a ritornello the recurrences of which are separated by interludes (Zwischenspiele), and that the piece shows how "triple counterpoint need not be stiff" and that "the subject has a strong ... rhythmic character." In the nuanced tuning this strong character is abetted by the fact that the semitone between $\mathrm{G}$ and $\mathrm{A}$ b is smaller and therefore more expressive than the one between $\mathrm{C}$ and $\mathrm{B}$; and indeed, it is appropriate to this particular melodic context that the leading tone does not sound very incisive. Please remember this point when I discuss presently the $\mathrm{C} \#$-minor fugue.

One feature of the linear structure inferred by Schenker (though declared nonexistent by a recent American expert on Bach) ${ }^{10}$ is the way in which the top line goes from the $\mathrm{D}$ in bar 17 to the $\mathrm{C}$ a step lower in bar 20 via a series of upward steps, pitch-class-wise, $D-E \natural-F \sharp-G-A \natural-B \natural-C$, but dropping a major seventh in bar 18. During this transition, there is a series of cross-relations-first between the left hand's $\mathrm{E} b$ in bar 17 and the right hand's $E$ ' $s$ a half-beat before and after, then between the left hand's $\mathrm{F}$ at bar 18 and the right hand's $\mathrm{F} \#$ a half-beat later, and so forth-so that the line of pitch-classes $D-E \natural-F \#-G-A \natural-B-C$ is transformed into a zig-zagging chromatic line, $\mathrm{D}-\mathrm{E} b-\mathrm{E} \natural-\mathrm{F} \natural-\mathrm{F} \sharp-\mathrm{G}-\mathrm{A} b-\mathrm{A} \downarrow-\mathrm{B} b-$ $\mathrm{B} \sharp-\mathrm{C}$. This operation is launched by the $\mathrm{E} b$ in bar 19 making a snug motivic semitone with the $\mathrm{D}$ just before it.

To write a $\mathbf{C} \#$-major prelude was inherently innovative, partly because there was no other $\mathrm{C}$-major music that such a prelude might serve to introduce. Nearly two hundred years later there would still be an innovative aura about the fact that the first movement of Ravel's Gaspard de la nuit is in this key; but this is, of course, because composing pieces in $\mathrm{D} b$ major, with its key signature of five flats, rather than in C\# major, with its signature of seven sharps, had meanwhile become a well-known procedure. Why did Bach write his prelude in $\mathrm{C} \#$ rather than $\mathrm{D}$ b major (which would have made it considerably easier to read)? David has written an interesting paragraph about this (156), to which I would add that Bach may have felt that (a) the sight of many sharps in the key signature would suit the bright and scintillating mood of the piece better than the sight of many flats, ${ }^{11}$ and (b) the extra difficulty-the double-sharps-would bring out the novelty of his project.

Looking at and listening to the sixteenth notes in the first five bars of the theme, one cannot help but notice that the first bar is melodically less straightforward than the other four. To anyone who investigates by playing in the nuanced tuning, the obvious reason for the difference is that $\mathrm{E} \#-C \sharp-E \#-C \#-$ $\mathrm{E} \#-C \#$ at the outset would have sounded sour. There exists an earlier draft of the piece in which the tune in the first bar is (middle) $\mathrm{G} \#-C \#-E \#-C \#-E \#-C \#$, the obvious reason for which would be to obfuscate the sourness. But that version is melodically too awkward. Perhaps it was by probing at the keyboard that

10 Dreyfus (1996, chap. 6) singles out Schenker's analysis of this piece as a model of bad theory. Several years ago I included some remarks about the analysis and the criticism in a lecture-recital in Istanbul entitled "An Introduction to Schenkerian Analysis" (Lindley 2003).

11 Such may have been the reason, mutatis mutandis, why Richard Strauss set the words "Ich habe deinen Mund geküsst, Jochanaan” at the end of Salome in C\# rather than in D, major. 
Bach found, in $E \#-C \#-G \#-C \#-E \#-C \#$, a satisfactory intermediate solutionintermediate inasmuch as (a) it is melodically less awkward than $\mathrm{G} \#-C \sharp-E \#-$ $\mathrm{C} \#-\mathrm{E} \#-C \#$ and $(\mathrm{b})$ the initial $\mathrm{E} \#$ sounds nicely pungent (in this particular context): the effect is of volatility rather than of sourness.

Another interesting aspect of this prelude is that whereas the ritornello principle is applied with an unusual degree of intensity in the first thirty-two bars and again in bars $46-62$, and whereas the episode in bars $33-46$ has meanwhile cultivated intensely the motif introduced in bars $6-7$, the remaining forty-two bars are, motivically, about as alien to the first sixty-two bars as they could possibly be while remaining in the same key, metre, and tempo. This feature of the piece was due to an "operation" rather than to a "procedure."

The final chord, for acoustic reasons described at the SIM website, is scintillating in the nuanced tuning in a way that is a more appropriate to this exact musical context than the equivalent chord in equal temperament.

I agree that the $\mathbf{C} \#$-major fugue is “one of Bach's sunniest” (158) and appreciate David's attention to the fact that it begins in the middle of a bar. I hear the first seven notes as an elaborate anacrusis to bar 2 and wanting to be "sung" (more than "danced") because, in the nuanced tuning, G\#-E\# is the largest major sixth (such major sixths, spelt as $\mathrm{A} b-\mathrm{F}$, are exploited lyrically in some other WTC pieces) and because the fourth note of the subject is F\# (a major seventh below $\mathrm{E} \#)$, not $\mathrm{F}$. Then again, the stepwise descent from middle $\mathrm{G} \#$ to $\mathrm{C} \#$ seems to me less interesting than the one in the upper octave from $\mathrm{E} \#$ to $\mathrm{C} \#$; the player should be aware that the line implied by those upper notes is full of suspensions, the first of which is resolved on the second half of the second beat of bar 2 (which is more interesting than if it were resolved on the second beat itself) and the last of which is resolved after the first note in bar 3 . I therefore prefer to hear this piece played somewhat more legato and cantabile than would be ideal for a bourrée or a gavotte. ${ }^{12}$ (If Bach played it in such a lyrical way, then it was probably a more innovative fugue than otherwise.)

I am more willing to hear the $\mathbf{C} \#$-minor prelude treated as a kind of "moonlight siciliano.” In the nuanced tuning it is advantageous for the $\mathrm{B} \#$ in the bass in bar 2 to make (as in bar 6 of Beethoven's Opus 27, No. 2) such a small semitone with the $\mathrm{C} \#$ just before it that its edginess helps prevent the music from sounding too relaxed. Likewise, that $B \sharp-C \#(C b-D b)$ is one of the smallest semitones in the nuanced tuning, and $\mathrm{B} \#-\mathrm{E}$ the smallest diminished fourth, helps prevent the $\mathbf{C} \#$-minor fugue from sounding too stodgy at the outset. And good for you if this remark makes you wonder whether Bach may have intended each WTC fugue subject to function better in the key in which he put it at the beginning of the piece than it would in a key with rather differently nuanced intervals in the unequal temperament. If so, then this was a brilliant innovation in the history of the genre: not only were a great variety of fugal techniques put on display in twenty-four keys but also the subjects exploited adroitly the resources of the nuanced tuning.

12 The relation between the nuanced tuning and this resulting interpretive approach to the piece will be clear to anyone who plays, on an instrument so tuned, as far as the first note of bar 2 in $\mathrm{C} \#$ major, then transposed to $\mathrm{C}$ major, then again in $\mathrm{C} \sharp$ - or, if she or he prefers, as far as the beginning of bar 5 . 
The somewhat sprightly but nonetheless flowing character of the D-major prelude is well accommodated by the tuning, as the thirds and sixths $\mathrm{D}-\mathrm{F} \#-\mathrm{A}-$ $\mathrm{C} \#-\mathrm{E}$ are tempered just enough to prevent them from sounding melodically dull, but less than would be ideally suited to agitated music. David points out (168) that the material in the first five-and-a-quarter bars is transposed down a fourth in bars 20-25. The sense of warmth there, owing to the difference in register and to the inherent warmth of subdominant in relation to tonic, is strengthened by the nuanced tuning, since G-B is tempered slightly less than $\mathrm{D}-\mathrm{F} \#$ and $\mathrm{D}-\mathrm{F} \#$ in turn slightly less than $\mathrm{A}-\mathrm{C}$. Sharps tuned relatively higher than their equivalents in equal temperament $(D \#, A \#, E \#)$ are used meanwhile-from the second half of bar 6 until bar 18-for the sake of fleeting references to $\mathrm{E}, \mathrm{B}$, and $\mathrm{F} \#$ minor. (The "fleeting" effect of these modulatory gestures is because the moto perpetuo texture is maintained by avoiding cadences.) The pedal point in bars $27-34$ is spiced by the G\#s (neighbour notes to $A$ ) in bars $3^{0-} 31$ and again in $33^{-} 34$, and the effect of the spice is strengthened by (a) the parallel-minor context, due to the local $\mathrm{B} b \mathrm{~s}$ and $\mathrm{F}$ ts, and (b) the cross-relation in bar 33 between high $\mathrm{F}$ h and middle $\mathrm{F} \#$. Bach may have intended us to sense a kinship between (a) the chromatically ascending diminished-seventh chords in bar 34 (with the $\mathrm{B}$ in in the second of those chords hinting at the forthcoming $\mathrm{C} \#$ a half-bar later) and (b) the chromatically descending diminished triads in bars $24^{-25}$ of the $\mathrm{D}$-minor prelude (with the $\mathrm{B} 4$ in the last of those chords hinting likewise at the $\mathrm{C} \#$ a half-bar later).

In the nuanced tuning the resolutely moderate tempering-not too much, not too little-of the thirds and sixths in the D-major scale (D-F\#-A-C\#-EG-B-D) helps the D-major fugue strut in its proper way.

There is not much gravitas at the beginning of the $\mathbf{D}$-minor prelude. The potential darker aspects of the Dorian have already been dwelt upon in the two previous minor-mode preludes. (They can thus be regarded as having been in two varieties of "transposed Dorian." The $\mathrm{D} \#$-minor fugue is another such piece.) I have mentioned the sweetness, in the $\mathrm{C}$-minor prelude, of the modulation to the relative major; the analogous modulation here in the $\mathrm{D}$-minor prelude seems to me not so much sweet as cheerful. The luminous clarity (in bars 5 and 7 ) of the F-major triad in the nuanced tuning contributes to this effect, after which the modulatory uses of $\mathrm{E} b$ (together with $\mathrm{F} \#$ in bars 6-7) and then of $\sharp \#$ (starting in bar 8-and in the nuanced tuning this note is tempered a little higher in relation to $\mathrm{E}$ and $\mathrm{B}$ than it would be in equal temperament) help launch the gradual build-up to a splendid display of Dorian virility at the end of the piece.

The apex of that display is at the beginning, in the anacrusis to the third beat in bar 24, of a chromatically descending chain of nine arpeggiated sonorities that I am tempted to call diminished triads even though nearly half of them are not notated as such. (In the first one, for instance: $\mathrm{G}^{\#}$ and $\mathrm{F}$ h cannot belong to the same triad but only to the same diminished-seventh chord.) I have suggested that the idea of doing something like this is anticipated in the pair of diminished-seventh chords in bar 34 of the $\mathrm{D}$-major prelude. It is easier, however, to sense a subdominant function (as a kind of $\mathrm{V}$ of $\mathrm{V}$ ) in the second dimin- 
ished-seventh chord in bar 34 of the D-major prelude than to sense such functions throughout the second half of bar 24 and first half of bar 25 in the D-minor prelude. An academically respectable set of theoretical harmonic functions can be assigned to all those sonorities, ${ }^{13}$ but if we were to imagine Bach improvising this passage, would we really imagine him sensing all those functions or would we suppose instead that it was only a contrapuntal shower within the harmonic orbit of the diminished-seventh chord occupying the first half of bar 24 and second half of bar 25 ? If the latter, then the operation was remarkable (though not a case of mere Klangfarbenmelodie as in Liszt's use of chromatically soaring and receding diminished-seventh chords to depict waves in "Saint François de Paule marchant sur les flots").

As an advocate of playing WTC in the nuanced tuning, I might claim that that tuning improves the effect of this passage; but in fact I have never sensed much benefit here. Nuanced semitones are more telling in clear harmonic progressions. ${ }^{14}$ The $\mathbf{D}$-minor fugue is just as un-sad as the prelude, and indeed less notable for any salient affect than for the fun of hearing the theme upsidedown nearly as often as right side up. This quality of the music is accommodated by the moderate tempering (in the nuanced tuning) of the intervals in the $\mathrm{D}$-minor scale; and yet the various $\mathrm{E} b \mathrm{~s}$, the $\mathrm{G} \#$ in bar 16, and the little $\mathrm{D \#}$ in bar 20 provide some strategically placed touches of colourfulness. (The Ebs in bar 9 are consequent to the entry of the theme on the second degree of the scale, $\mathrm{E}$, in bar 8 . The unorthodox nature of that operation is expanded upon by the upward leaps of a fourth from $\mathrm{F}$ to $\mathrm{B} b$ at bar 9 and on to $\mathrm{E} b$ on the second beat of the bar.)

The last two bars of the piece bring out that it is, so to speak, all about symmetry and asymmetry in the scale. A thorough discussion of this (delving into the asymmetrical tonal relationship between tonic and dominant and that the major and minor triads each have an asymmetrical intervallic structure, but mirror each other) would be too long-winded, but let me describe a relevant aspect of the nuanced tuning. Because of its own subtle asymmetry (described in the SIM website)-whereby $\mathrm{B} b-\mathrm{D}$ is tempered slightly more than $\mathrm{D}-\mathrm{F} \#$, $\mathrm{E} b-\mathrm{G}$ more than $\mathrm{A}-\mathrm{C} \#$, and so on-the half-steps in $\mathrm{D}$ minor between the leading tone and the tonic $(C \#-D)$ and between the fifth and sixth degrees of the scale $(\mathrm{A}-\mathrm{B} b)$ are more similar in size than are the analogous intervals in any other minor key (except for $\mathrm{G} \#$ minor, halfway around the circle of fifths from D minor; see below). A palpable difference in their sizes would have tended to distract from the abstract, somewhat affect-free fun, in this rather unassuming piece, of hearing the subject inverted so many times.

13 \begin{tabular}{l|c|c|c|c|c|c|c|c|c|c|} 
Top edge of line: & $\mathrm{B}^{\natural}$ & $\mathrm{B}$, & $\mathrm{A}$ & $\mathrm{G}^{\sharp}$ & $\mathrm{G}^{\natural}$ & $\mathrm{F}^{\sharp}$ & $\mathrm{F}^{\natural}$ & $\mathrm{E}$ & $\mathrm{E} b$ & $\mathrm{D}$ \\
\hline Chord analysis: & $\mathrm{E}^{9}$ & $\mathrm{~A}^{9}$ & $\mathrm{~B}^{7}$ & $\mathrm{E}^{9}$ & $\mathrm{~A}^{7}$ & $\mathrm{D}^{9}$ & $\mathrm{E}^{9}$ or $\mathrm{G}^{7}$ & $\mathrm{~A}^{9}$ & $\mathrm{D}^{9}$ & $\mathrm{E}^{9}$
\end{tabular}

14 It was only after nuanced tuning had been altogether forgotten that Schoenberg undertook to compose "mit zwölf nur auf einander bezogenen Tönen" (with twelve tones that are related only with one another). He also declared (in a letter of 10 June 1934 to Joseph Yasser) that "ein Sänger, der natürliche Tonhöhen angibt, ist unmusikalisch, so wie jemand unsittlich sein kann, der sich auf der Strasse 'natürlich' benimmt" (Yasser 1953, 55) - “a singer who produces natural pitches [i.e., pure untempered intervals] is unmusical, just as one choosing to act on a street in a 'natural' way would be considered indecent" (ibid., 61; my interpolation). 
The $\mathbf{E} b$-major prelude reminds me of three very affect-laden organ pieces, excerpts from which can be heard at the SIM website performed in a properly nuanced tuning: the expressive chorale prelude on "O Mensch, bewein' dein' Sünde gross" (BWV 622, composed several years before WTC), the tender one on "Schmücke Dich, o liebe Seele" (BVW 654, composed soon after WTC), and the monumental prelude (BWV 522/1, composed at least ten years after WTC) at the beginning of Clavier- $\ddot{U} b u n g$ III. The salient use of $\mathrm{D}$ b in the first two bars of the WTC prelude is matched by equally telling uses of $\mathrm{D} b$ in those other three pieces. David's characteristically interesting discussion of the WTC prelude mentions some ways in which it is "typical of Bach's maturity in creating a union of opposites" (175). Another such way is that although this is the grandest of the WTC preludes, it begins with a touch of tenderness (in the $\mathrm{D}$ b in bar 1, so intimately close to the $\mathrm{C}$ in bar 2 ) and then in bar 2 there is a hint of "vulnerability" in the remarkably large major sixth between $\mathrm{A}$, and $\mathrm{F}$ before the further soaring - via the somewhat tender $\mathrm{A} b$ in bar 3 - to the top of the tessitura in bar 5 . The resulting "gentle giant" quality of the piece is an additional example (and probably innovative at the time) of "creating a union of opposites."

Let me mention, by the way, that in bars 1-10 the chain of thirds that ascends pitch-class-wise in the tune (as indicated by the bold letters in the following reduction) extends beyond the $\mathrm{C}$ in bar 5 to the $\mathrm{E} b$ at bar 7 :

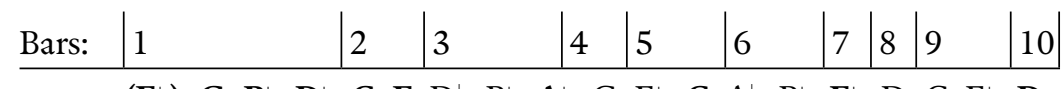

$(\mathbf{E} b)-\mathbf{G}-\mathbf{B} b-\mathbf{D} b-\mathbf{C}-\mathbf{F}-\mathrm{D}^{\natural}-\mathrm{B} b-\mathbf{A} b-\mathrm{G}-\mathrm{E} b-\mathbf{C}-\mathrm{A} \natural^{\natural}-\mathrm{B} b-\mathbf{E} b-\mathrm{D}-\mathrm{C}-\mathrm{E} b-\mathbf{D}$

David quite sensibly takes as the starting point for his discussion of the $\mathbf{E} b$-major fugue the fact that it is in a much lighter style than the imposing fugue within the prelude, and he discusses expertly $(176-77)$ its formal plan and the deft little chromatic inflections in the subject, in the first half of bar 6 and in "the Schumannesque final bar." Those inflections are just about as effective in equal temperament as in the nuanced tuning, and yet Bach's apparent awareness of the tuning nuances can be inferred from a certain kind of subtle difference between the expositions in this fugue and those in the A-major prelude, which is likewise sprightly and wanting (in my opinion) to be played allegretto. In the A-major prelude, the operative $\mathrm{D} \sharp$ s in the mini-modulation to the dominant occur on strong beats (in bars 4 and 5 ), whereas in the $\mathrm{E} b$-major fugue, the $\mathrm{D} b \mathrm{~s}$ and most of the $\mathrm{A} b \mathrm{~s}$ in the first twelve bars occur on the strong parts of beats (albeit weak beats), but meanwhile $A$, the leading tone to the dominant, occurs only on the weak parts of beats. Bach could write very tender music in $\mathrm{E} b$ major, and I have described a masculine, "gentle giant" aspect of the $\mathrm{E} b$-major prelude; in this fugue, when played properly in the nuanced tuning, I find rather charming the "tameness" of the $A \sharp$ in bar 7 as it makes a calmer leading tone to $\mathrm{B}$, than does $\mathrm{D}$ to $\mathrm{E}$. 
Let me state here an underlying generalisation that is readily inferred from Figure 1, which contains two circular diagrams, the first in regard to the tempering of thirds and sixths, the other in regard to the sizes of semitones: in major keys with sharps in their signatures, the thirds and sixths are tempered more in V than in I (these Roman numerals stand for triads), but less in IV and ii, and the leading tone to the dominant is melodically more incisive than the one to the tonic, but the leading tone to the subdominant less so; whereas in the WTC major keys with flats in their signatures it is the other way around: the thirds and sixths are tempered less in V than in I, but more in IV and ii, and the leading tone to the dominant is melodically less incisive than one to the tonic, but the leading tone to the subdominant more so. ${ }^{15}$ I will come back to this point when discussing $W T C$ pieces in $\mathrm{A} b$ and $\mathrm{B} b$ major.

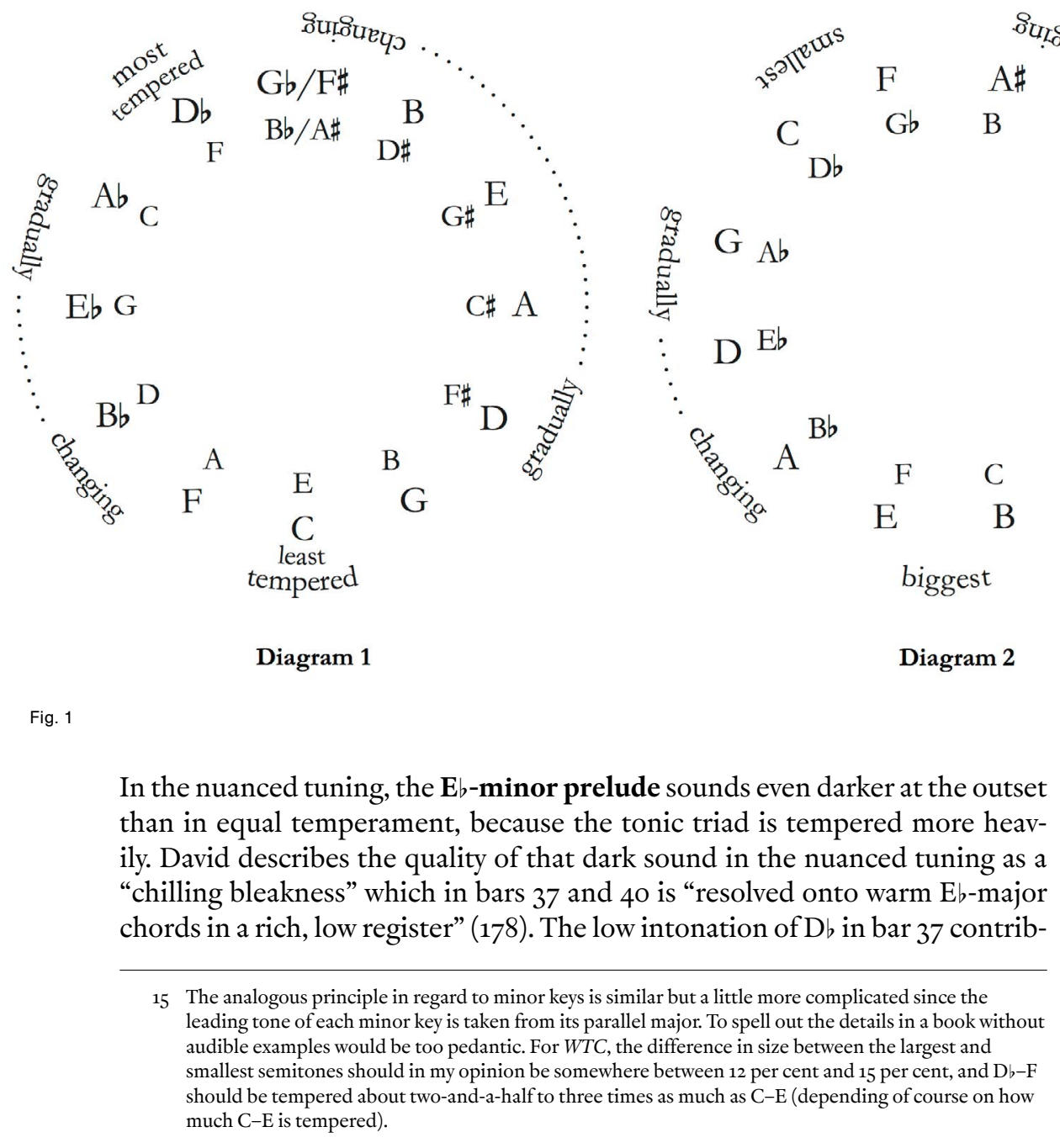


utes to the sense of warmth there, and meanwhile the heavy tempering of the $\mathrm{G}$ b-major triad has ensured that, in bar 5 , that chord sounds tense and does not have the kind of luminous clarity that the arpeggiated F-major triads have in bars 5 and 7 of the D-minor prelude.

The subject of the $\mathbf{D} \sharp$-minor fugue sounds more expressive in the nuanced tuning than in equal temperament because the semitone between the fifth and sixth degrees of the scale is slightly smaller and the third degree of the scale is slightly lower in relation to the tonic. David mentions (182) the "virtual certainty that this fugue was originally in D-minor." The transposition brought out the expressive potential of the theme, and this helps prevent the "very elaborate scheme of normal exposition, followed by one with stretto; then normal exposition with the subject inverted, followed by one with stretto inverso; and finally one with the subject in augmentation" (100) from wearing out its welcome.

David aptly describes the E-major prelude as featuring cantabile-style arpeggios and as making use of the ritornello principle (183), in connection with which he mentions the dominant (B major) at bar $81 / 2$ and the subdominant (A major) at bar 15. He sees in this piece a "typical keyboard texture for the projection of a right-hand melody, mainly with one melodic part in the right hand and two accompanying ones in the left." It seems to me, however, that the arpeggiated triads played by the left hand in bars $3^{-4}, 8,13^{-14}, 17^{-18}$, and 23 are thematically significant; and I therefore spot a ritornello at bar 17 .

The nuances of the tuning play a clear and expressive role in relation to the harmonic plan of this piece. The sound of $\mathrm{G} \#$ and $\mathrm{D} \#$ tuned relatively higher and less pure in relation to $\mathrm{E}$ and $\mathrm{B}$ than they would be in equal temperament creates at the outset (in my opinion) an affect of somewhat nervous lyricism. (The tuning has the same kind of effect, only more so, at the beginning of the B-major prelude.) I have mentioned the introduction of gradually smaller semitones in bars 6-15 of the C-major prelude; in bars $3^{-12}$ of the E-major one there is an analogous series $(A \#-B, E \#-F \#, B \#-C \#)$ and yet also in bars $6-7$ a pair of successively larger semitones $(C \#-D, F \#-G)$ in the momentary dip into the parallel minor ( $\mathrm{B}$ minor) of the dominant. The harmonic plan as far as the beginning of bar 14 is a matter of modulating from $\mathrm{E}$ to $\mathrm{B}$ major to $\mathrm{F} \#$ minor and then back via $\mathrm{B}$ to $\mathrm{E}$. I hear in the first modulation (the one from $\mathrm{E}$ to $\mathrm{B}$ ) a stepwise descent of a major sixth:

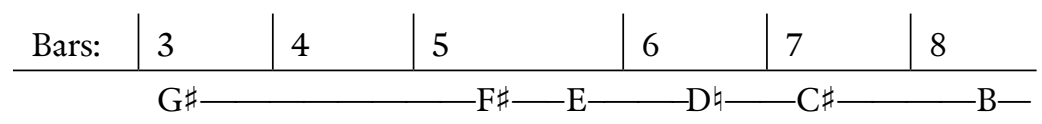

and then a descent in bars $11-14$ from $\mathrm{D}^{\natural}$ (serving in bar 11 as the sixth degree of the $\mathrm{F} \#$-minor scale) to $\mathrm{G} \#$ :

\begin{tabular}{l|l|l|l|l} 
Bars: & 11 & 12 & 13 & 14 \\
\hline & $\mathrm{D} \sharp-\mathrm{C} \sharp-\mathrm{B}-\mathrm{A}-\mathrm{G} \sharp-$
\end{tabular}


In bar 14 the $\mathrm{D}^{\natural}$ recurring in the E-major chord carries the modulation, which has begun in the previous bar, a step further down in the chain of fifths to A major at bar 15 . The sense of subdominant warmth there is exquisitely augmented by the fact that $\mathrm{A}-\mathrm{C} \#$ is tempered less than was $\mathrm{E}-\mathrm{G} \#$ in bar 1 .

The tonal path from here to the middle of bar 22 is so much like that of the first seven-and-a-half bars that a modern musician is likely to see the resemblance to a characteristically Schubertian recapitulation starting in the subdominant. ${ }^{16}$ The operation in this piece is extremely artful. The semitone between $\mathrm{B}$ and $\mathrm{C}$ in bars $20-21$ is the largest one in the piece; the deceptive cadence in bar 22 to a $\mathrm{C} \#$ chord undoes refreshingly the parallel-minor aura; and the final plagal cadence recalls the subdominant ritornello and the fact that it was nuanced less nervously than the initial statement of the theme. (NB: If the piece is transposed a semitone higher or lower to a key with one or more flats instead of sharps in its signature, that ritornello and this chord sound more nervous than the tonic.)

The tempering of the E-major scale in the nuanced tuning is equally well suited to the saucy discourse of the E-major fugue; and the palpably high tuning of the leading tone in the relative minor key (i.e., $B \#$ leading to $C \#)$ helps to prevent that auxiliary key from sounding sad in bars 11-16. However, it does sound sufficiently askew (I am referring just to the nuances, not to the underlying relation between the tonic and its relative minor) to make the return to the E-major scale and the subsequent uses (in bars 22-24 and 27, with their fleeting hints of A major) of a slightly larger semitone $(\mathrm{C} \sharp-\mathrm{D} \sharp)$ than has been heard hitherto in this piece sound more soothing than the use of the same intervals would sound in some very different context, for instance in a piece in C or G major.

The E-minor prelude is from the outset a remarkably unusual keyboard composition. According to David (185), one reason for this is likely to have been an "origin in improvisation," and he gives several reasons why. The sudden A-minor presto at bar 23 does indeed seem to me like an idea that popped up spontaneously in the course of improvising. From my specialist point of view it is also interesting, in the context of the supposed improvisational origin of the piece, that the effectiveness of the somewhat drifting earlier modulations (to $\mathrm{G}$ major at bar 9, back to $\mathrm{E}$ minor at bar 11, on to $\mathrm{C}$ major at bar 13 and $\mathrm{A}$ minor at bar 15 , then back to $E$ at bar 21) is abetted in the tuning by a chiaroscuro of nuances in the notes that are pivotal to the modulations. And, in bars 2-4, the rather small semitone (smaller than in equal temperament) between $\mathrm{D} \#$ and $\mathrm{E}$ is felicitous in the same way as the small semitone between $\mathrm{B} \#$ and $\mathrm{C \#}$ (mentioned above) in bars $5^{-7}$ of Beethoven's "Moonlight" Sonata.

16 It happens also in the famous first movement of Mozart's "Sonata facile," but in that piece the subdominant triad would be, in the nuanced tuning, tempered more than the tonic, rather then less as here. Plus c'est la même chose, plus ça change. (Documentary evidence hinting that Mozart would probably have had the keyboard tuned in some such nuanced way is set out in Chesnut [1977].) 
A bigger point, however, is that musicians who improvise and who are creatively inclined are likely often to cross the line between "procedures" and "operations"; but it is only when the music is preserved by notation (or, in more recent times, by recording) that improvised operations are likely to be noted. Thus, when dealing with someone like Bach, we should hardly assume that every apparent operation in his compositions was fresh-baked for him at the time; he might well have done it before in improvisations.

In each of the four modulations to a major key in the E-minor fugue, the tuning provides a series of successively less incisive sharps and analogous naturals: (1) $A \#, G \#, F \#, B \sharp$ at bars $5,7,9,11 ;(2) C \#, F \#, B$ औ, E in bars 15-18; (3) D\#, C\#, $B \natural, F$ at bars 24, 26, 28, 30; and then (4) G\#, C\#, F\#, B 4 in bars 34-37. Each modulation back into a minor key involves accordingly a salient use of a relatively incisive leading tone. This systematic use of nuances contributes to the shapeliness of the piece-which wants such a contribution because the resources for contrapuntal dialogue and an interesting texture are limited in a fugue à 2 .

The F-major prelude starts out "pastoral"-a normal choice of affect for this key-with a two-bar pedal point during which one might naturally be inclined to play the sixteenth notes legato; but then that affect is discarded, and many of the remaining sixteenth notes should be articulated more energetically. This curious shift so near to the beginning was a notable innovation and perhaps even a joke on the tradition of writing pastoral music in this key. (The E-major prelude, in fact, sounds more pastoral.) The trills in bar 3 may distract one from noticing, in the nuanced tuning, that $\mathrm{B} \sharp-\mathrm{C}$ is not a smaller semitone than $\mathrm{B} b-\mathrm{A}$ (in bar 2). However, the $\mathrm{C} \#$ in bar 4 makes a clearly more incisive leading tone, and then just about halfway through the piece a shrill high point is introduced by a note that is not only the most heavily tempered sharp in the piece $(\mathrm{G} \#)$ but is salient also because it ascends in such an unorthodox way from $\mathrm{F}$ to $\mathrm{A}$ in bars 8-9 (i.e., with an augmented second between $F$ and $G \#)$. After the right-hand line has worked its way back down an octave to the A in bar 13 , an expressively "corrective" flourish on $G \sharp$ in bars $14^{-15}$ prepares for the leap up to high $C$ in bar 15 :

\begin{tabular}{l|l|l|l|l|l|l|l|l|l|l|l|l|l|l|l|l|l|l|l} 
Bars: & 1 & 2 & 3 & 4 & 5 & 6 & 7 & 8 & 9 & 10 & 11 & 12 & 13 & 14 & 15 & 16 & 17 & 18 \\
\hline
\end{tabular}

(So the player should put an agogic accent on the $\mathrm{G}$ in the middle of bar 14 and also, to a lesser extent, on the $\mathrm{C}$ in the middle of the next bar, and meanwhile make a bit of rubato just before that high C.)

A "pastoral" aspect of the F-major fugue is the unadventurous harmony within each of its four sections: (1) bars 1- 32 in F and C major (a double exposition of the fugue subject), (2) bars $34^{-46}$ in D minor, (3) bars $47^{-5} 5^{6}$ in $\mathrm{G}$ minor, and (4) bars $57^{-72}$ in F. Each section has a distinctive tonal palette. In the first one, the pitch-classes are the naturals and $\mathrm{B}$; ; in the second, $\mathrm{B} \sharp$ is absent, and almost every bar displays $\mathrm{C} \#$; the third one features a hovering between $\mathrm{F} \#$ and $\mathrm{E} b$; and then the last one differs from the first owing to the absence of $\mathrm{B}$ h and 
the repeated uses of $\mathrm{E} b$. The tuning-nuances strengthen the effects of these changes in tonal hue.

Certain features of this piece might be considered innocent jokes (innocent to fit in with pastoralism, as does the fact that the tonal palette includes no very impure consonant intervals): the slightly topsy-turvy subject, the voice-crossing in bar 6 , the capricious skips in bars $13^{-15}$, the pedal point on $\mathrm{A}$, the hemiola in bars 70-71. Had the character of the prelude been likewise innocent, the effect of the two pieces together could have become insipid, and this may have been Bach's reason for making the prelude so unpastoral.

The F-minor prelude and fugue are drenched in dark affects. In discussing the $\mathrm{C}$-minor prelude I mentioned how the low intonation of the $\mathrm{A} b \mathrm{~s}$ and $\mathrm{E} b \mathrm{~s}$ strengthens from the outset the sense of minor-mode darkness in that piece (and I could have mentioned, but didn't, that the stodgy effect of the somewhat large semitone between the leading tone and the tonic is helpful in that regard); and then how the low intonation of the $\mathrm{A}$ bs in the bass in bar 10 helps render the modulation to $\mathrm{E} b$ sweeter than any old ordinary modulation to the relative major; and the refreshing acoustic clarity of the much less heavily tempered final E⿱ The corresponding nuances in $\mathrm{F}$ minor have similar flavourings but in slightly different doses, and the differences as well as the similarities are telling. The $\mathrm{C}$-minor prelude is dark in a hefty way, but the F-minor one is full of melancholy and pathos-for which it is appropriate that $\mathrm{A}$, is even darker in the $\mathrm{F}$ triad than is $\mathrm{E} b$ in the $\mathrm{C}$ triad, that $\mathrm{D} b-\mathrm{C}$ is an even smaller semitone than $A b-G$, and that $E$ is the lowest possible leading tone in the nuanced tuning, its effect in bars 2-4 being to convey a sense of pathetic weakness. The arrival on the relative major in bar 14 of the $\mathrm{C}$-minor prelude is less charged with tension than the arrival on the relative major at bar 9 of the F-minor prelude. The tension in the latter case is well prepared for by the extreme tempering of $\mathrm{D} b-\mathrm{F}$ in bars 7-8. David mentions the unequal temperament in his brilliant account of this piece (191-92) and says that the first four phrases are of the following lengths in quarter notes: $6+4+4+8$. The bass line in the third and fourth phrase, and again in bars 10-11, features augmented whole-steps, evidently in order to get maximum pathos from the very small semitones $(\mathrm{C}-\mathrm{D} b, \mathrm{~F}-\mathrm{G} b, \mathrm{G}-$ $\mathrm{A} b$ ) and remarkably low leading tones (E, A, B).

Since the prelude is written in common time, it would seem that the phrases after the first one each begin on a weaker beat than the first one did. But I feel that those other phrases do not really start on secondary beats, so I hear the music as if written in $2 / 4$ time and with an initial three-bar phrase (whereby the next phrase would start on a beat that is just as strong as the first one). Within each such bar and within each beat I treat the second half as pathetically weaker than the first - and likewise within each eighth-note sub-beat I phrase most of the sixteenth notes in pairs, for greater pathos (with a modicum of flexibility in the tempo).

It seems to me, however, that to treat likewise the quarter notes in the theme of the fugue would be insipid. Given its see-saw melodic aspect, I think that only its second note, the one introducing a remarkably small semitone (in the nuanced tuning) in the minor-mode statements but an inherently radiant 
whole tone in the major-mode statements later on, should be emphasised; and then the other quarter notes can be played with a kind of smooth patiencewhereby this piece sounds just as good, in my opinion, in equal temperament as in the nuanced tuning.

Having discussed half of WTC, let me now (a) presume that the reader understands various ways in which the nuanced tuning functions in relation to harmony and expression, and therefore (b) cover more efficiently the other half by focusing less on such details (many of which are covered in the SIM website) than on relations between them and various peculiarities, perhaps innovative, of some of the pieces. I would not carry the argument too far by declaring, in regard to all the WTC pieces, what Bach's not very intelligent former pupil Johann Philipp Kirnberger (1769, ii), when defending in 1769 his own incredibly crude kind of nuanced tuning, declared in regard to all the compositions of Bach and several other masters: ${ }^{17}$

\begin{tabular}{|c|c|}
\hline $\begin{array}{r}\text { Wer nun } \\
\text { diese Verschiedenheit der Terzen } \\
\text { und übrigen Verhältnisse } \\
\text { mit dem Gehöre unterscheidet } \\
\text { (und sie sind zu unterscheiden), } \\
\text { wird } \\
\text { ohne boshafte Absichten } \\
\text { ein Stuck nicht } \\
\text { in einen andern Ton } \\
\text { transponiren. } \\
\text { Denn nicht ein einziges Stuck von } \\
\text { seligen Bach, Graun, Händel, } \\
\text { Hernn Capellmeister Bach } \\
\text { in Hamburg, } \\
\text { unn in einen andern Ton versetzt werden, } \\
\text { ohne es zu verunstalten } \\
\text { und unpraktikabel machen. }\end{array}$ & $\begin{array}{l}\text { Now whoever } \\
\text { distinguishes by ear } \\
\text { these differences in the } 3 \text { rds } \\
\text { and [in] other relations [i.e., intervals] } \\
\text { — and they are distinguishable- } \\
\text { will not } \\
\text { (except [perhaps] with evil intent) } \\
\text { transpose } \\
\text { a piece } \\
\text { into another key; } \\
\text { for not a single piece by } \\
\text { the late [J.S.] Bach, Graun, Händel, } \\
\text { Capellmeister [C.P.E.] Bach } \\
\text { in Hamburg, } \\
\text { and other great composers } \\
\text { can be set in another key } \\
\text { without deforming it } \\
\text { and making [it] impracticable. }\end{array}$ \\
\hline
\end{tabular}

I think that other considerations were (of course!) sometimes more important to Bach, but that he was nevertheless attentive to his own preferred style of nuanced tuning when composing WTC, and that this was a remarkably creative aspect of the project. Since so many of my findings concern fine points of the affects, it could be argued that a pun latent in the adjective temperirt-whereby it can refer to two different nouns: (1) Temperatur, the word for musical tem-

17 Quantitative aspects of Kirnberger's work on tempered tuning are assessed in Lindley (1987b, 278-83, see also 276). Kirnberger eventually admitted (a) that it had all been a waste of time and (b) that Bach had taught him to tune all the major thirds larger than pure (a teaching which he ignored by tuning C-E pure). Some modern writers say that this latter point proves that Bach used equal temperament. That argument is just as inept as Christoph Wolff's confusion (see note 3 ) of equal and unequal temperament. 
pered tuning (as well as temperature), and (2) Temperament, which in the eighteenth century covered the "melancholic" and the "phlegmatic" as well as the "sanguine" and the "choleric" - was operative in Bach's title. ${ }^{18}$ I wouldn't insist on this, but I do think that WTC had some consequences in the history of the Tonartencharakteristiken. ${ }^{19}$

I have mentioned that the tuning of $\mathrm{G} \#$ and $\mathrm{D} \#$ fosters an "an affect of somewhat nervous lyricism" at the outset of the E-major prelude and that the same kind of thing happens at the beginning of the B-major one, so I needn't describe in detail the relation between (a) the tuning of the extreme sharps and (b) the evasive nimbleness, in the $\mathbf{F} \#$-major prelude, of the tune with its peculiarly dense uses of échappés and the like in 12/18 time (and the novel ending on a double-octave sonority), and then in the $\mathbf{F} \#$-major fugue the peculiarly lyrical "pins and needles" motif introduced in bar 7 and inverted in bars 12-13 to make a countersubject with an exquisitely "yearning” E\# in bar 13 (and then the unusual - in those days-final chord). These superbly innovative pieces sound as dull as dishwater when transposed to F major and performed in the nuanced tuning.

I have described how the relatively low tuning of the leading tones in the Cand F-minor preludes contributes to the dark and heavy aura of those pieces, and how the relatively high tuning of $\mathrm{B} \#$ in the pieces in $\mathrm{C} \#$ minor (and of $\mathrm{D} \#$ in the ones in $\mathrm{E}$ minor) helps prevent them from sounding darker or heavier than they should, so I needn't dwell on how the tuning of the extreme sharps helps to keep the mood of the F\#-minor prelude suitably light. In the F\#-minor fugue those nuanced sharps and $F_{x}$ support what David aptly describes (198) as a powerful "union of materials and expression."

I have mentioned also "the nicely paced introduction of gradually smaller semitones" in bars 6-15 of the C-major prelude, starting with $\mathrm{F} \#-\mathrm{G}$ in bars 6-7. In the livelier G-major prelude this happens in bars 2-9, after which there is a gradual tapering back in the next five bars (leading to the use in bar 14 of the largest semitone, E-F) and then a settling down, in the last three-and-a-half bars, to the same range of interval sizes as in the first two.

The sizes of the semitones and dosages of tempering of the thirds and sixths (neither too much nor too little for the thematic material to have, very nicely, its properly nuanced quality) in the G-major fugue are akin, mutatis mutandis, to those in the D-major fugue that I have mentioned; and likewise for the G-minor, $\mathbf{G} \#$-minor, and A-major preludes and fugues. (Of course the validity of these assertions can be judged only by ear.) In the A-major fugue I am impressed by the whimsical freedom with which the theme is reshaped one way and another. That kind of freedom seems to me likely to have been innovative for the genre in Bach's day. (Frescobaldi may have inspired him in this regard..$^{20}$ I doubt that he would have done such a thing in a fugue in a very

18 See, for example, Krünitz ([1773-1858] 2014). In writing the title of WTC, Bach used German letters for wohl and Clavier and Latin-type letters for temperierte.

19 For an essay on various technical aspects (not just tempered tuning) of the history of Tonartencharakteristik, see Lindley (2015).

20 See the last paragraph of the main text of Oron (2008). 
traditional key or in an extreme one (tuning-wise) calling for a more "serious" affect. The $\mathrm{G} \sharp$-minor prelude also seems to me remarkably light-hearted, more ballevole and gentle than one might expect of a minor-mode piece (one can waltz to it, though of course that was impossible in Bach's day, as the waltz did not yet exist), even though the theme features saliently a diminished seventh. Some of my remarks about the D-minor fugue drew upon the fact that in the nuanced tuning the semitones in that key between the leading tone and the tonic $(C \sharp-D)$ and between the fifth and sixth degrees of the scale $(A-B b)$ are more similar in size than are the analogous intervals in any other key except this one. The symmetry in D minor served one kind of purpose there; here in the $G \#$-minor prelude the analogous symmetry in bars 1-2 serves as a foil for the asymmetry in the subsequent statements of the theme in other keys. The lilt is basically there when the piece is performed in equal temperament, but the piece sounds more interesting (and more interestingly lilting) when performed in the nuanced tuning.

If the extraordinarily large major sixth in the subject of the $\mathrm{C} \#$-major fugue is, as I have suggested, cause to play that piece cantabile, then surely the same goes for the $\mathbf{A} b$-major fugue.

The $\mathbf{A} \mid$-major prelude, however, treats that modern key (modern in those days) so differently and so innovatively that David in his excellent discussion (206-7) senses a "seeming mismatch" between the style of the piece and its key. The style is that of the first movement of a Baroque concerto-of which there are no examples (as far as I know) in Ab major but plenty in $\mathrm{G}$ or A. Let us examine the relation between the nuanced tuning and the harmony.

The heavy tempering of the tonic chord at the outset and on the second beat of bar 3 helps it serve a function analogous to that of a triple- or quadruple-stop orchestral chord in a violin concerto. (Think of K. 216.) The main drift of the tune in the first three bars is to go up from the first to the second to the third degree of the scale; in that context the second degree is macrorhythmically just a passing note, so it is appropriate that the $\mathrm{V}$ chord in bar 2 is tempered a little less obtrusively than the tonic chord in bars 1 and 3 -which would not be the case if the piece were in $\mathrm{G}$ or $\mathrm{A}$ major instead of $\mathrm{A} b$. The first phrase consists of five bars, as the left-hand part in bars $3-5$ marches up from the first to the second to the third degree of the scale the way the right-hand line did in bars 1-3. The $\mathrm{A}$, sonority at the beginning of bar 5 is a high open-fifth chord (extremely unusual for Bach) rather than a triad: one reason for this, obvious to anyone who investigates the music in the nuanced tuning, is to avoid having another somewhat harsh-sounding $\mathrm{A} b$ triad in bar 5 like the one in bar 3 . But there is no such compunction at the beginning of bar $2 \mathrm{O}$ : the $\mathrm{E} b$ triad is tempered a bit less heavily than an $\mathrm{A}$ b one, yet, even so, an effect analogous to that of a triple- or quadruple-stop sonority is gained by having five notes in the chord instead of three of four.

In discussing the $\mathrm{E} b$-major fugue I praised the "tameness" of the $\mathrm{A} \sharp$ in bar 7 making a calmer leading tone to $\mathrm{B} b$ than does $\mathrm{D}$ to $\mathrm{E} b$, and $\mathrm{I}$ alluded to the fact that in each WTC major key with flats in its signature (unlike in major keys with sharps in their signatures) the thirds and sixths are tempered more in the 
IV or ii triad than in I or V, and the leading tone to the dominant is melodically less incisive than the one to the tonic. Here in the $\mathrm{A} b$ prelude I notice, in the modulation to the dominant in bars $9-18$, that the introduction in bars $9-10$ of the new leading tone, $\mathrm{D}$ (tuning-wise a less urgent leading-note to $\mathrm{E} b$ than $\mathrm{G}$ is to $A$ b), ushers in a stepwise descending sequence in bars 10-12; but when the bass line has then marched down a tritone to land on $\mathrm{A} b$ at bar 13 , the sonority at that moment is the most heavily tempered (compound) major sixth in the nuanced tuning, and the ensuing implied subdominant chord of the new key ( $\mathrm{E} b$ major) frames an ascending sequence in bars $13^{-15}$ and sounds pivotal to the modulation. This kind of thing doesn't happen in modulations to the dominant in pieces with sharps in their signatures. (Bar 3 of the G-major fugue provides a clear and simple counter-example.)

There is yet another notable way in which the nuanced tuning has evidently influenced the harmony in this piece. Chord-wise, bars 1-5 and 39-42 are full of seesawing back and forth between I and V. This is unusual for Bach. Where are the subdominant chords of $\mathrm{A} b$ major, and what are they like? They are in bars $26,28,32$, and 44 . The one in the first two beats of bar 26 represents, after the $\mathrm{G}$ bs in bars $24^{-25}$, a hint that this is where a subdominant ritornello would have been appropriate if the tempering of the $\mathrm{D} b$-major triad had been less extreme. The only $\mathrm{D} b$ chord with a complete triadic sonority (analogous to those of the $\mathrm{A} b$ chords in bars 1 and 3 and the $\mathrm{E}$ b chords in bars 2, 18, and 20) is in bar 44 . I play it as if Bach had written a wedge over it; it thus becomes, because of its extreme tempering, like a friendly punch strengthening the final cadence and confirming the un-mellow affect of the piece.

There is an apparent unwillingness in WTC to indulge in languid affects in the major keys with flats in their signatures. The sprightly treatment of $A$ b major in the prelude (an idea that did not exert much influence on later composers' uses of that key) balances the smoother quality of the fugue. The bubbly $\mathrm{E} b$ fugue provides refreshment after the "gentle giant" quality of its prelude. $\mathrm{D} b$ major is pre-empted by $\mathrm{C \#}$; soft pastoralism is evaded in $\mathrm{F}$ major; and the $\mathrm{B}$ b-major fugue, the affect of which is akin to those of the $\mathrm{E} b$ fugue and the A-major prelude, is preceded by a funky, toccata-like prelude. (The idea of occasionally putting funky musical ideas in $\mathrm{B} b$ major did catch on with later composers-even in the mid-twentieth-century American settings of "Look Mother, I can fight, I can work, I can play" and "When you're a Jet, you're a Jet all the way."

According to David's apt description (221) of the $\mathbf{B} \mid$-major fugue, it is "as much a galant character piece as a demonstration of counterpoint." The repeated-note motif in the first countersubject (bars 7-9) bestows a certain happy-go-lucky affect to the dominant that is nicely served by the fact that its leading tone $(\mathrm{E} t)$ is the most laid-back one possible in the nuanced tuning. After the soprano provides in bars $13^{-17}$ the second statement of the answer and has thus put that laid-back leading tone on a high-flying flag (as it were), the flag proceeds to wave some slightly more incisively tuned F\#s in bars 17-22;

21 These lines are from Gian Carlo Menotti's Amahl and the Night Visitors (1951) and Leonard Bernstein's West Side Story (1957). See Lindley (2015, chap. 4). 
further steps in the use of colourfully tempered notes are taken later on with the introduction of $\mathrm{Ab}$ and (in bar 33 ) $\mathrm{C} \#$; then there is a reversion in bars $41-48$ to the original diatonic palette of bars $1-5$.

There is nothing happy-go-lucky about the dominant or about getting to it in the first half of the $\mathbf{B} \mid$-major prelude. The modulation, starting in bar 3 , is as elaborate and roundabout as the corresponding one, discussed above, in the $\mathrm{A} b$-major prelude, and I think the reason why is the same. Some of the lineaments of that modulation are as follows:

\begin{tabular}{|c|c|c|c|c|}
\hline Bars: & \begin{tabular}{|l|l|}
$1-3$ & 4
\end{tabular} & $5 \mid 6$ & 7 & 89 \\
\hline
\end{tabular}

(I have put " $\mathrm{D}$ " and "C" in bold partly to suggest a certain, albeit vague, analogy with the $A$ and $G$ in bars 13-14 of the F-major prelude. The analogy is vague because the contexts are very different.)

There is no $\mathrm{C \#}$ in this piece, but its second half includes some colourful, albeit brief, uses of $\mathrm{D} b$ in bars 15 and 17 and of $\mathrm{G} b$ in bars $16-17$. Two of the three uses of $A b$ - the ones in bars 11 and 18 - are pivotal in the structure of the piece. (You will surely have noticed by now, without my having to dwell on the point, that $A b-G$ is smaller than any melodic semitone in the first half of the piece.) The tune in bars 11-18 sails down from the fifth degree of the scale to the tonic:

\begin{tabular}{l|l|l|l|l|l} 
Bars: & $11-12$ & $13-14$ & 15 & $16-17$ & 18 \\
\hline & $\mathbf{F}-\mathbf{E} b-\mathbf{D}-\mathrm{D} b-\mathbf{C}-\mathbf{B}$,
\end{tabular}

The left hand's Ab at bar 18 elides (a) the right-hand part's arrival on the tonic with (b) a three-bar coda. The right hand's $\mathrm{A} b$ in bar 18 is, in my opinion, even more interesting. I sense retroactively in the last note of bar 10 an enharmonic switch whereby that quick note serves not only as $\mathrm{G} b$ in relation to $\mathrm{F}$ but also as $F \#$ in relation to the $G$ played by the right thumb in bar $11-$ which is thus targeted by a diminished $3 \mathrm{rd}, \mathrm{F} \#-\mathrm{A}$. If Bach also heard this, then it is the only enharmonic moment in WTC and one of the very few in all his compositions.

Notice also the curious switching back and forth in bar 12 between $\mathrm{B}$ a and $\mathrm{B} b$. This subtle little operation can be explained by supposing that if another instrument were to supply soft accompanying chords, it would not hold the $\mathrm{G}^{7}$ chord throughout bar 12, but would insert a second-inversion C-minor chord on the third beat and then revert to the $\mathrm{G}^{7}$ chord on the fourth beat.

David points out (218) that the harmonic formula of the first four bars of the A-minor prelude is the same as in the C-and D-minor preludes. It is remarkable that here in the A-minor prelude the pitch classes for the subdominant chord in bar 2 are exactly the same as for the dominant one (plus the pedal point) in bar 3 . This is achieved by having the stepwise path of the top edge of the tune in these four bars (from the fifth degree of the scale up to the tonic) include an augmented second. In the nuanced tuning, the large semitone 
between the fifth and sixth degrees of the scale, and then the sprightly leading tone (with $\mathrm{G} \sharp-A$ being just about the same size as in equal temperament), help prevent one from inferring any touch of sadness such as one might well do if these four bars were transposed into $\mathrm{B} b$ minor and played (in the nuanced tuning) at a moderate tempo.

The first modulation is to a ritornello at bar 4 in $\mathrm{E}$ minor, where the colder affect (owing mainly to the harmonic relation between $\mathrm{E}$ and $\mathrm{A}$ minor) is well served by the slightly edgier leading tone $(\mathrm{D} \#)$. But then there is a remarkably long and warm ritornello in $\mathrm{C}$ major. The performer can gain an anticipatory sense of warmth in the approach to it in bars 9-10 by dwelling on the $\mathrm{C} \#$ in bar 9 and the $B$ in bar 10: the succession there of larger semitones $(C \#-D, B-C)$ after $A \sharp-B$ at bars $8-9$ strengthens the inherently warm effect of the descending sequence (descending harmonically in the chain of fifths as well as in pitch). If the first eight-and-one-third bars of this piece might perhaps evoke an image of a crouched boxer dancing about in the ring, bars 11-16 might evoke, first, an image of stretching out one's arms with palms open to greet pleasant sunshine and then, of course, some kind of happy culmination at bar 16; but then yet another posture is taken up at bar 17. I won't go into further detail here about the harmonic and linear structure of the piece (there is more discussion of this at the SIM website), but let me mention that after B-C has been the smallest semitone in bars 10-16, there is a notable touch of colour (more colourful in the nuanced tuning than in equal temperament) in the chromatic descent from $\mathrm{E}$ to $\mathrm{E} b$ to $\mathrm{D}$ in bars $16-17$, and the sharps provide a series of successively smaller semitones $(F \#-G, C \#-D, G \sharp-A)$ in bars $17^{-24}$. For a short keyboard piece to feature such a clear and yet elaborate succession of quite different affects-I have metaphorically called them postures-may have been even more innovative than the joke (if that's what it was) of starting out "pastoral" in the F-major prelude and then going on in quite a different vein. The nuances of the tuning were so vital to the innovation here in the A-minor prelude that modern players performing the piece in equal temperament have not, as far as I know, noticed it.

The step up of an augmented second in bars $2-3$ is recalled obliquely in the leap down of a diminished seventh between the same two pitch classes in the subject of the A-minor fugue-which is like the D-minor one in being neither sad nor very joyful and in being full of the fun of hearing the theme upside down nearly as often as right side up. But whereas the inversions in the $\mathrm{D}$-minor fugue dwell subtly on the similar size of $\mathrm{C} \#-\mathrm{D}$ and $\mathrm{B} b-\mathrm{A}$, here in the A-minor one (a) the analogous semitones differ in size and (b) in each inversion, the diminished seventh is replaced by some other kind of seventh. This fugue is also full of strettos from bars $27^{-2} 8$ onwards. David analyses expertly and succinctly $\left(229^{-} 30\right)$ the plan in that regard. The range of modulations is wider than in the far less grand D-minor fugue; but, even so, no extremely small semitones are used: the smallest ones are $\mathrm{D} \sharp-\mathrm{E}$ and $\mathrm{E} b-\mathrm{D}$. The first use, in bar 5 , of $\mathrm{D} \#$ is salient and refreshing, and so also (in my opinion-but the effect is very subliminal when one's attention is focused properly on the contrapuntal tricks) are its recurrences in bars 31 and 80 . The only uses of $E b$, in bars 74-75, 
are nicely located a dozen bars before the end of the piece. (Together with F\# it points to a subdominant triad [G minor] of the subdominant key [D minor]; that G-minor chord then progresses duly to an A-major chord as V7 [bars 77-78] of $\mathrm{D}$ minor [bar 79], from which in turn the harmony moves on ahead to dominant and tonic chords of the main key.)

After the comments offered earlier on the $\mathrm{E} b$ - and F-minor preludes, it is unnecessary to go into detail here as to how helpful, in the $\mathbf{B} b$-minor prelude and fugue, the extremely small semitones with flats $(\mathrm{D} b-\mathrm{C}$ and $\mathrm{G} b-\mathrm{F})$, the rather unincisive leading tone ( $\mathrm{A}$ l leading to $\mathrm{B} b$ ), and the moderately tempered Picardy third $(\mathrm{B},-\mathrm{D})$ are to players wishing to have these pieces sound as pathos-laden as possible. (The advantage of playing them in the nuanced tuning rather than in equal temperament is like that of reproducing certain old photographs in sepia rather than black and white.)

And after using phrases like "exquisitely yearning" and "somewhat nervous lyricism" when discussing the E- and F\#-major preludes, I needn't go into detail as to the expressive value of the notably small semitones and heavily tempered thirds and sixths with sharps in the B-major prelude and fugue.

Tuning nuances are less telling in the B-minor prelude. In the magnificent second part of the piece it is nice to have $\mathrm{A}-\mathrm{C} \#$ in bar 20 tempered less than $\mathrm{B}-$ $\mathrm{D} \#$ in bar 18 , to have the $\mathrm{E} \#$ at bar 22 and the one in the middle of bar 26 and the one just before the middle of bar 45 making in each case a very small semitone with the preceding $F \#$, to have the $A \#$ in bar 32 tempered higher in relation to $\mathrm{C} \#$ than the preceding $\mathrm{G} \#$ is to $\mathrm{B}$, and likewise mutatis mutandis in bar 37 , and so on; but equal temperament suits very well the steady walking-bass aspect of the music. The innovative aspect of the piece was to make it much bigger than a slow movement of this kind by Corelli; this did not require nuances in the tuning. The fugue is a different matter. With so much chromaticism, a modicum of nuance in the tuning can sometimes be like a handful of flavourings in a ragout, ${ }^{22}$ where it is generally more important to have notable flavourings than to have exactly this or that one in this or that morsel. In this piece, however, the effect is more artful. While the chordal implications are unclear in bar 2, the very small semitone at bar 3 points to the arrival on the $\mathrm{F}$-minor triad after the departure from the B-minor one in bar 1; the same kind of thing happens at bar 5 , and then the remarkably small semitones at analogous moments in statements of the theme later on as the harmony becomes more opulent are exquisitely beautiful. David's account (233-34) of the various harmonic contexts of the theme and their relation to the structure of the piece is concise and very informative.

Readers who know WTC intimately may forgive me for writing so much about details.

22 Mattheson (1720) used this metaphor in the passage cited in note 4. He said he didn't like too much vinegar, pepper, and other spices in his ragout, but he did like a nuanced tuning in his music, whereby "les tons transposés sont plus singuliers \& plus étranges." 


\section{REFERENCES}

Artusi, Giovanni Maria. 1589. Seconda parte dell'arte del contraponto nella quale si tratta dell'utile et uso delle dissonanze. Venice: G. Vincenti.

Chesnut, John Hind. 1977. "Mozart's Teaching of Intonation.” Journal of the American Musicological Society 30 (2): 254-71.

Dreyfus, Laurence. 1996. Bach and the Patterns of Invention. Cambridge, MA: Harvard University Press.

Kirnberger, Johann Philipp. 1769. Vermischte Musikalien. Berlin: George Ludewig Winter.

Krünitz, Johann Georg. (1773-1858) 2014. “Temperament." Oekonomische Encyklopädie Online. Accessed 22 December. www.kruenitz1.uni-trier.de/ $\mathrm{xxx} / \mathrm{t} / \mathrm{kto}$ oo6.htm. Digitised version of Krünitz's Oekonomische Encyklopädie, first published $1773^{-18} 85^{8}$.

Ledbetter, David. 2002. Bach's Well-tempered Clavier: The 48 Preludes and Fugues. New Haven, CT: Yale University Press.

Lindley, Mark. 1987a. "Bachs Stimmung des Klaviers.” In Alte Musik als ästhetische Gegenwart: Bach, Händel, Schütz: Bericht über den Internationalen Musikwissenschaftlichen Kongress, Stuttgart 1985, edited by Dietrich Berke and Dorothee Hanemann, 2 vols., 1:409-21. Kassel: Bärenreiter. Translated into Dutch as "Klavierstemmingen van J. S. Bach" (Het Orgel 81 [6]: 409-21, 1985). Translated into English as "J. S. Bach's Tunings" (The Musical Times 126 [1714]: 721-26, 1985).

_-_.1987b. "Stimmung und Temperatur." In Hören, Messen und Rechnen in der frühen Neuzeit, edited by Frieder Zaminer, 109-331. Geschichte der Musiktheorie 6. Darmstadt: Wissenschaftliche Buchgesellschaft.

-. 1997. "A Quest for Bach's Ideal Style of Organ Temperament." In Stimmungen im 17. und 18. Jahrhundert: Vielfalt oder Konfusion?, edited by Günter Fleischhauer, 45-67. Michaelsteiner Konferenzberichte $5^{2}$. Michaelstein, Germany: Stiftung Kloster Michaelstein. —__. 2003. "An Introduction to
Schenkerian Analysis.” Academia.edu. Accessed 18 December 2014. https:// www.academia.edu/1670986/An_ introduction_to_Schenkerian_analysis. . 2012. "Valuable Nuances of Tuning for Part I of J. S. Bach's “Das wohl temperirte Clavier.”' Staatliches Institut für Musikforschung. Accessed 26 December 2014. http://www.sim.spkberlin.de/wtc_973.html.

———. 2015. "A Rudimentary Approach to the History of the Major and Minor Keys." Academia.edu. Accessed 30 January. www. academia.edu/326349/A_rudimentary_ approach_to_the_history_of_the_major_ and_minor_keys.

Lindley, Mark, and Ibo Ortgies. 2006. "BachStyle Keyboard Tuning.” Early Music 34 (4): 613-23.

Mattheson, Johann. 1720. Reflexions sur l'eclaircissement d'un problème de musique pratique. Hamburg.

Neumann, Werner, and Hans-Joachim Schulze, eds. 1969. Fremdschriftliche und gedruckte Dokumente zur Lebensgeschichte Johann Sebastian Bachs 1685-1750. Kassel: Bärenreiter.

Oron, Aryeh. 2008. "Girolamo Frescobaldi (Composer).” Bach Cantatas Website. Accessed 22 December 2014. www.bachcantatas.com/Lib/Frescobaldi-Girolamo. htm.

Schenker, Heinrich. 1932. Fünf Urlinie-Tafeln. Vienna: Universal Edition. Translated by Felix Salzer as Five Graphic Music Analyses (New York: Dover, 1969).

Schulze, Hans-Joachim, ed. 1972. Dokumente zum Nachwirken Johann Sebastian Bachs 1750-180o. Vol. 3 of Bach Dokumente. Kassel: Bärenreiter.

Werckmeister, Andrea. 1697. Hypomnemata musica. Quedlinburg: T. P. Calvisii.

Wolff, Christoph. 200o. Johann Sebastian Bach: The Learned Musician. New York: Norton.

Yasser, Joseph. 1953. "A Letter from Arnold Schoenberg." Journal of the American Musicological Society 6 (1): 53-62. 


\title{
Tales from Babel
}

\section{Musical Adventures in the Science of Hearing}

\author{
Edward Wickham \\ St Catharine's College, Cambridge
}

One of the more disconcerting experiences I have had in my career as a consort singer and director of vocal ensemble the Clerks came at the first rehearsal for a new project entitled The Clerks' Songbook. The brief of this specially devised programme was to create new, contemporary texts ("contrafacta") for medieval and Renaissance songs and motets. We engaged a number of poets to devise English translations and adaptations of texts originally conceived in French or Latin, though without insisting either on literalism or on exact replication of the metre or rhyme scheme of the model.

The thinking that inspired the project was simple. By presenting these works in an accessible language, we hoped to engage our audiences in a more direct relationship with the performance, one that was not based simply on reverence for an ancient, exotic genre, expressed in distant, recondite language. I was interested in particular to see whether the polytextual works that underwent this transformation would have greater impact if their language became comprehensible. The interplay of texts in thirteenth- and fourteenth-century motets has been the subject of much scholarly literature, ${ }^{1}$ and I was curious to see whether the rich and subtle intertextuality in these works, which has resulted in analyses of forensic intensity, would enhance our audiences' appreciation.

What I had not considered was the effect such transformations from the medieval to the contemporary would have on the singers themselves. The Clerks is a freelance ensemble whose members sing in a wide range of classical genres. Some will give solo recitals and sing occasional operatic roles; many sing regularly in church and cathedral choirs; and all participate in that hectic and varied choral environment that is the professional British choral scene.

\footnotetext{
DOI http://dx.doi.org/10.11116/9789461661883.cho6

1 Particularly in response to Christopher Page's provocative discussion in the third chapter of Discarding Images: Reflections on Music and Culture in Medieval France (1993, 65-111). See, for example, Bent (1993, 1997). Recently, the discussion has moved on to include the wider environment of listening in the Middle Ages; cf., for example, Dillon (2012).
} 
Members of the Clerks will generally have long experience of Renaissance and contemporary polyphony, and in their time they have risen to many technical and aesthetic challenges. And yet when we started to rehearse a contrafactum of Andrieu's Armes, amours - a ballade that laments the death of Guillaume de Machaut - the difficulty of traversing the gap between the old and the new became painfully apparent.

For this was no literal translation of Andrieu's poem that writer Anneliese Emmans Dean had presented us. The subject of the lament was no longer the poet-composer Canon of Rheims, but the recently deceased Michael Jackson. The singers squirmed. It seemed to them at first-as it may do to many of you reading this- to be a glib, modish stunt, with nothing other than the cheekiness of the concept to justify it. In fact, Dean's text is playful but also considered, respectful, and artful: the two texted vocal lines present two different perspectives on the celebrity, one delivered by an adoring fan, the other by a tabloid journalist fascinated by prurient detail. Now that the group has performed it several dozen times-and perhaps as the memory of Michael Jackson recedes-we are easier with the disjunction of words and music, the singers feeling less exposed by the immediacy and contemporaneity of the text.

Why singers should feel so unsettled by articulating Dean's poem when they are often asked to sing things equally or more uncomfortable in other contexts is a question that has many answers, some of them straightforward, some of them a good deal more complex; but it is not the ambition of this essay to unpick the network of motivations and expectations that define the work of an ensemble such as the Clerks. Suffice it to say that one of the simpler answers is that it often feels quite alright to be singing about sexual violence or even expressing anti-Semitic views, ${ }^{2}$ just so long as one's conscious, intellectual engagement with the text is deadened by unfamiliar language.

As it transpired, the Clerks need not have worried, since nobody in the audience at that first performance, or in any subsequent performance, has ever managed to pick out more than a few disassociated words. Only at the end of the ballade, when, instead of "La mort, Machaut," the full ensemble sings "Michael, Michael!" is the trans-historical conceit articulated so explicitly that listeners get it. Otherwise, the two upper voices weave around each other in beguiling but largely unintelligible fashion, Dean's ingeniously deployed internal rhymes and semantic associations largely unnoticed. The commitment of the two upper voice singers to articulating the text should not be doubted (however queasy it has made them feel); consonants are precise, vowel sounds uncovered, vibrato minimal; while the lower voices, vocalising on /u:/, maintain a discreet dynamic distance from the upper voices. ${ }^{3}$ But for all this care and attention to foregrounding the texted voices and declaiming the texts cogently, audiences tend to smile indulgently and either turn to their programmes to find out what is going on or sit back and let it wash over them.

2 I am thinking in the first instance of the motet Clap, Clap/Sus Robin from the Ivrea Codex; and in the second, of the Easter sequence Victimae Paschali laudes.

3 A recording and the text of $A$ Lament on the Death of Michael Jackson can be found at http://www.talesfrombabel.co.uk. 


\section{Edward Wickham}

It came as something of a shock to realise, after almost twenty years of performing with the Clerks and others, that audiences may not hear as much of the text we singers are conscientiously articulating as we might like or expect. Of course, different types of texts in choral polyphony require different types and levels of engagement. The words of the mass, whether in Latin or the vernacular, are and were sufficiently well known to the faithful that intelligibility is strongly reinforced by expectation-which is not to say that text declamation was not, at different times and for different reasons, an important criterion for mass composition. The same might be said of the most familiar liturgical texts. Songs and madrigals with nonsense lyrics or that follow extremely conventional poetic themes require considerably less attention from the listener than settings of the unfamiliar and the poetically ambitious.

What category the medieval motet falls into has been the subject of some debate, with important ramifications for the way we might understand texted polyphony in general and for how we might go about realising it in performance. In Discarded Images, Christopher Page (1993, 99-111) argues that the aesthetic ambition of the polytextual motet should be understood not as involving subtle textual interplay- the brain teased by the complex cross-relations between poetic lines-but instead as one that uses the dance of language as primarily a timbral device, the intelligibility of individual words, still less of entire phrases, being of subsidiary importance. The debate that Page provoked has stimulated a multitude of fresh insights into the role of text in the medieval-motet genre and the ways in which those texts might be understood within a culture of musical participation and appreciation. Environment and expectation play a large part in these new formulations of the argument, but the question remains a valid one: How much of the words in a polytextual motet are we-unprompted, unconditioned-capable of hearing and making sense of?

Tales from Babel is a concert programme devised, at least originally, to address this particular question. With music by Christopher Fox setting my own libretto, the programme is formed of a series of musical vignettes, each demonstrating aspects of the problem of text intelligibility in vocal polyphony, with the whole forming a quasi-narrative that mirrors the story of the Tower of Babel in Genesis. The project was funded by the Wellcome Trust and toured the UK in $2013 \cdot{ }^{4}$

The idea that this fundamental question might be addressed by scientific means was prompted by conversations with Anna Zayaruznaya, whose $\mathrm{PhD}$ on the Ars Nova motet discusses the phenomena known to speech scientists and psychologists as "auditory streaming" and "the cocktail party problem" (Zayaruznaya 2010, 73-105). Auditory streaming refers to the process whereby the brain analyses an auditory environment or "scene," discriminating between different elements to make sense of one noise against another. The cocktail

4 For more information about Tales from Babel, see http://www.talesfrombabel.co.uk. 
party problem - a phenomenon first discussed by Colin Cherry in two studies from the 1950s (Cherry 1953; Cherry and Taylor 1954) - arises when the streaming process is applied to a multitude of simultaneous speech signals. The challenge of holding a conversation in a crowded room is one that we all encounter and one whose difficulty increases as, with age, our hearing degrades. It is one of the major impediments to effective cochlear implant treatments, and it often contributes to social awkwardness and isolation for the hearing impaired. Zayaruznaya's identification of the cocktail party problem as an access point to discussion of the "polytextual motet problem" was intriguing.

Further inspiration came from an academic biologist who directed me towards tests devised by the audiologist and speech scientist Douglas Brungart to test air-traffic controllers in the United States (Brungart et al. 2001). The tests, designed to be taken in laboratory conditions, entail the participant listening to a series of multivocal, or polytextual, stimuli. Up to six voices simultaneously articulate phrases having the form "[NAME] go to [COLOUR] [NUMBER]" (for example, "FRANCES go to RED FIVE," or "ROGER go to BLACK NINE"). From this crowd of voices, the test participant is required to follow the voice whose phrase begins with the name "Roger." Ignoring all the other, distractor, voices, the participant then notes what colour and number Roger is ordered to go to. The voices are spatialised as best as can be achieved using stereo headphones, their intensity, positioning, and rhythm varying with each stimulus.

Quite apart from the bewilderment with which one initially reacts to this challenge, the Brungart test created, to my ears and the ears of composer Christopher Fox, a fascinating sound world, characterful yet disembodied, ritualistic yet personal; and it is with a simulation of a Brungart test that the first work in our project, entitled Roger go to yellow three, opens. Six characters declaim Brungartian lines simultaneously and monorhythmically. After some time, ripples of activity can be detected on this uniform surface. Characters start to declaim in different rhythms and introduce new lines of text. The personalities of Roger, Frances, and the rest begin to assert themselves, and a drama ensues. The centrepiece of this twenty-minute work is a complex polytextual "motet" in which the characters reveal their inner anxieties and passions before being herded back to the imaginary laboratory from which they temporarily escaped.

Roger go to yellow three, with its references to the Pentecost and "speaking in tongues," became the second act, or New Testament section, of a drama that begins with Tales from Babel. Here the Old Testament story of mankind's hubris, and God's typically vengeful response, provided a framework for a series of works exploring language and music. In one section, the audience is encouraged to "switch streams"- to shift their attention from one singer to another-when hearing three voices in different combinations of speech and song. Various other distracting devices are employed: one voice part carries a bawdy story, into another the names of audience members are inserted, thus simulating one of the curious aspects of the cocktail party problem, which is that we manage, while apparently filtering out distractor voices, to process background stimuli. If our name is spoken across a room, however crowded, we may still hear and respond to it. Another section references the medieval 
hocket and plays with words associated with neuroscience to encourage mishearings when voices are layered one on top of the other. In the finale, a performance of the Renaissance song Fortuna desperata is ruined by the discordantand thus foregrounded-singing of one of the characters.

While these sections of Tales from Babel involve scientific exposition and demonstration, three further sections entail specific tests for the audience on the intelligibility of sung text. The tests were devised through collaboration between the musical team and Professor Sarah Hawkins (Centre for Music and Science, University of Cambridge), and Drs Antje Heinrich and Sarah Knight (both MRC Institute for Hearing Research, Nottingham). These tests represent a formalised and coherent attempt to conduct scientific research at a live, concert performance and to collect meaningful data that can stand alongside and be usefully compared with data collected in the rarefied environment of the laboratory. Our intention when devising the tests was that they should interfere as little as possible with the narrative coherence of the programme and with the prevailing atmosphere of the presentation. A PowerPoint presentation was created to help explain the test procedure, and wireless data-gathering units linked to a laptop were issued to the audience to facilitate responses, along with pen and paper questionnaires.

The first test serves as a calibration and control test. Each member of the Clerks introduces his or her character by delivering information as if in a personal ad on a dating website: name, age, place of birth, married or single, hobby, and some other point of interest. Thus: "My name is ROGER, I am FIFTY-NINE years of age, I come from STRATFORD ... I am MARRIED. My hobby is wINE TASTING . . . I HAVE BUILT A GAZEBO.” The key information points (here in capitals) are recorded by the test participants on a grid. These lines are sung against a low-level, static chord, vocalised on single vowel sounds. The intention in this test is to establish the characters and voices in each audience member's mind, to identify any audience members whose hearing might be so impaired that they cannot perform satisfactorily even in this low-threshold task, and to gauge any effect that different venues and their acoustics might have on intelligibility.

Test Two resembles in music a generic SPIN (Speech Perception in Noise) test as employed in many types of audiology research..$^{5}$ One of the Clerks-the same singer for each stimulus and for each presentation of the test as a wholesings successive lines of text in silence and against three different types of background noise, created by the other singers: a simulated "white noise" created by "shushing" (///); pitched vowel sounds forming a chord cluster; and speech babble. These noises are presented at two different intensities. Over the course of six concerts, 120 test conditions have been presented, each with a different combination of sentences, background noises, and intensities of background noise.

The sentences were composed by Sarah Hawkins, and they include predictable and unpredictable contexts for each of the target words. Thus, for instance, the word "flock" appears in "The birds flew overhead in a huge flock" (pre-

5 For a description, see Kalikow, Stevens, and Elliott (1977). 
dictable) and in "The boys knew where to look for a huge flock" (unpredictable). The singer presenting the text takes care to hold up his or her music so as to prevent lip-reading by the audience and (though this took some practice) to avoid the natural temptation to "lombard," or raise or lower the volume of delivery, in response to the higher or lower volume of the background noise. ${ }^{6}$ On the PowerPoint screen, audience members are presented with four possible answers-for "flock" they might be "flock," "frock," "block," or "crowd"and register their answers via the Wi-Fi handsets. Though this is not revealed to the audience, the first eight stimuli in each test (of twenty stimuli in total) are designed as controls and calibration tests; they also give audience members an opportunity to become comfortable with the handsets.

Just as Test Two is based on a common speech science test, so Test Three has parallels in speech-based research. ${ }^{7}$ Here we simulate dichotic hearing tests in which two streams are played simultaneously and the participant asked to discriminate between the two. In a laboratory environment, the participant will generally listen through headphones and receive individual streams into left and right ears. In our live performances, this level of stream segregation is neither possible nor desirable, since listeners with normal hearing will at a live concert experience all streams through both ears, albeit in a mix of intensities depending on where one is seated relative to the sound sources.

In our Test Three, pairs of voices sing monorhythmic lines in note-againstnote counterpoint. Listeners are primed to follow one particular line, and they are asked what two words they hear at the conclusion of the phrase. As in the previous test, the singers cover their faces with their music to prevent lip-reading. The narrative context for this test is a cocktail party to celebrate the opening of Roger and Frances's new gazebo. This gives the opportunity for some self-referential humour, thus:

Singer One: "We've got wonderful acoustics, I can make out every word."

Singer Two: "You can hold a conversation even when there's lots of noise."

The audience is primed to listen to the stream introduced by the words "You can hold a conversation ...", so the correct answer would be "lots of noise." Six options are offered to audience members, from which they choose using the handheld Wi-Fi device; in this instance, these are "every noise-lots of noisehale or gale-lots of words - tots with toys-every word." Note that these possible answers include the phrase that appears at the end of the distractor voice, "every word," as well as phrases similar to this and the correct version.

One of the questions we initially posed ourselves when devising this test was whether, as in speech-based dichotic listening tests, listeners could be encouraged to switch their attention from one stream to the other. Thus a listener might start by attending to the target voice but then, through some musical or textual device, shift attention to the distractor. In speech-based tests, the

6 The Lombard effect, after French otolaryngologist Étienne Lombard.

7 See, for example, Lewis (1970). 


\section{Edward Wickham}

strategy here is straightforward: to encourage a switching of attention, the sense of the two streams is switched, so that a sentence begun in one ear continues in the other and vice versa. When music is linked to text the parameters become considerably wider. Does the listener follow the sense of the words, as in a dichotic speech test, or the logic of the melody (however one might care to define that)? How does one account for the differing timbres of voices, for the effect of consonance and dissonance, and for contrapuntal voice-leading?

There was considerable discussion about how best to approach these questions, and indeed this was the most time- and thought-consuming element of the collaboration as a whole. One challenge lay in effectively testing whether listeners would notice the switch in sense. In a number of conditions, the sentences begun in one voice were concluded in the other, thus:

Singer One: "Sturdier than bricks and mortar, tougher than a timber job." Singer Two: "We've made friends with all the builders, they've done such a sterling frame."

Primed to listen to the stream beginning "We've made friends with all the builders ...", the correct answer in this instance would be "sterling frame," a phrase that makes considerably less sense than "sterling job," the answer one might give if one followed not the stream but the sense of the text.

Just as with the text pairs, the musical material went through many revisions. In its final form we used just one melody for all the target voice phrases, and we used two forms of distractor line, one consonant and one dissonant. The melodic lines occupy the same register and cross over on occasion. The sixvoice ensemble is divided into three pairs, one female-voice pair and two malevoice pairs; when singing, the members of each pair match each other's timbre as closely as possible, with both singing in an uninflected style and obscuring their mouths when they do so. Seventeen voice-pair conditions are presented in one test; and, unlike Test Two, where the arrangement of conditions changes from presentation to presentation, Test Three remains the same, the only change being in the order in which the possible answers are arranged on the PowerPoint screen.

Judging by the range of work for which the Wellcome Trust provides financial support, art-and-science collaborations can take many forms. The most common involves an artist demonstrating scientific ideas or processes through artistic media; in these instances, the resulting work expounds and expresses the science that inspired it. Artists are adept at appropriating things to inspire them, and it is no surprise that artists tend to get a lot more out of these sorts of collaborations than scientists do.

The central challenge in putting together Tales from Babel was to create a work that performed those same functions-scientific exposition and demonstration-while at the same time generating data by means of tests that might 
eventually inform scientific research. The tensions that arose as a result of the sometimes-opposing requirements to entertain and to regulate included everything from presentational methodology to compositional technique, and they were a reminder that the ecosystem of the concert is especially rich and diverse.

In presentational terms, discussions were had over the use of a PowerPoint projection. The use of a screen immediately prompts expectations of a pedagogical presentation, and alerts audiences to prepare for a different type of aesthetic experience than the typical concert. How much talking should there be in the concert? Again, the more lecture-style the exposition, the more dislocated audiences might become from the concert experience. How long should the tests go on? There was a concern that the audience tests would so interrupt and stultify the musical flow of the programme that they would destroy the pacing of the musical narrative. Should the singers deliver the tests in a particular way so as to render the live voices as anonymous as possible-for example by covering faces and suppressing expression and timbral inflections? All these questions, and many more, were discussed as part of the process of controlling the live auditory experience.

There are, of course, far too many parameters to control adequately in a live performing environment, and one must pick the ones that seem most relevant. Thus we opted for masking the singers' faces when delivering the tests since it became clear early on in the project that audiences were attempting to lip-read their way to the correct answers. The tests were split up in such a way that the complete data set is made up of results from a series of concerts, so as to avoid a tediously lengthy sequence of tests; and, as already stated, the singers were asked to sing in a relatively uninflected way, avoiding the natural tendency to raise the volume of the voice in order to compete with other voices. In many other respects, however, one has to resign oneself to the experimental deficiencies that a live performance environment entails. As soon as an audience member walks through the door, sits down, and opens the programme, she or he is having expectations set and modes of listening primed. Even before, when an audience member sees the poster, reads the flyer, or encounters some other form of publicity for the concert, the ears are being prepared. Most especially, pencil and paper, questionnaires and a Wi-Fi handset are not the usual paraphernalia one expects to be given at a conventional concert of lieder or polyphonic choral music, and audiences will undoubtedly be listening in a different way as a result.

One particular experimental problem, not unique to our approach but one that needs to be considered in all intelligibility studies of sung text, involves the positioning of target words within a test condition. Invariably our target words come at the end of phrases, and there are good methodological reasons for doing that, not least so that the occurrence of the target word is entirely predictable. In spoken and especially in sung texts, the confounding of final consonants and the distortion of vowels brought about by the following words can have a profound effect on the pronunciation and intelligibility of a word. Furthermore, the requirement placed on participants to identify just a single 
word, by pressing a number on a keyword, may inadvertently be encouraging participants to switch off attention to all but the target word itself. A test that monitored a participant's understanding of a whole phrase would be more desirable in this respect, though bringing with it a further set of challenges. ${ }^{8}$

In addition, there are the challenges of regularising conditions from concert to concert. Different halls, with different acoustics, different seating plans, and audiences with different expectations-all of these might potentially compromise the data. As it has transpired, it appears that these elements have had a far less disruptive effect than one might imagine and that test results across the nine presentations are of a reassuring consistency. The next step here will be to reproduce the tests in a laboratory environment and compare the two data sets.

Awareness of these sensitivities reminds us that, just as language intelligibility relies upon complex patterns of rhythms and pitch, so the experience of a live performance is built up of expectations and desires that form patterns framing our understanding and appreciation of that performance. We enter a church with a generous acoustic to hear a choir singing polyphonic music in Latin. We open a programme printed in antiquarian typeface. The lights are dimmed, the performers appear in sombre attire and do not make eye contact with the audience. We know roughly what to expect from such a performancean immersive experience rather than a directly rhetorical one, perhaps-and our listening is calibrated accordingly. Different scenarios prepare us for different forms of engagement with the performers and for a different engagement with the words in that performance. To ask the audience to articulate the meaning of a particular text phrase-or even the text of an entire work-is as artificial an exercise as to ask whether they heard a single word in a phrase of music. Meaning, in so far as it can be expressed at all through the text of a piece of music, inheres in the patterning and deployment of text, not through the intelligibility of particular words.

While some of these challenges were anticipated, many were not, and we experienced a steep learning curve in the first few months of the project. The first pilot test that we conducted, including music students from Cambridge University, featured material from the opening of Christopher Fox's score Roger go to yellow three, described earlier. This was similar to a Brungart test, employing six voices; the main difference was that the lines were delivered in formal and simultaneous monorhythm by all the voices, rather than in speech rhythms. A second test employed music from the middle section of Roger (the "motet section" also described above). Here we invited listeners to fill in the gaps in phrases of text sung in the midst of the six-voice polyphony.

The results of these informal tests were startling in the poor level of performance even by young musicians with excellent hearing; and they were the first indication that I and the Clerks had that audiences hear much less text than we think they do. In the pseudo-Brungart test, results were no better than the level of statistical chance, forcing us to revise the test so that in any one condition,

8 See Wickham (2014) for discussion of this with respect to intelligibility tests conducted in laboratory conditions by Johnson et al. 
only one distractor (spoken solo or in unison by two to five voices) would be set against the target (similarly spoken solo or by several voices). 9 This revised test was more successful, and it supported hypotheses that would seem intuitive: for instance, that increasing the number of distractor voices compromises the intelligibility of the target voice. However, while not specifically testing for the effect of loud against soft declamation, the results encourage a further hypothesis, one which could be of significance for composers and performers: namely, that intelligibility of the target voice is enhanced more effectively when several voices reinforce it than when a single target voice simply declaims more loudly. This would seem to be the case whether the target voice is reinforced by male or female voices. (There are good acoustical reasons why this hypothesis is a reasonable one for musical performance, though it is not my place to discuss them here.)

The second test was abandoned after three outings for two reasons: first, audiences found the task too difficult; and second, the number of confounding elements in the test environment produced results that were contradictory and irreconcilable. This was a disappointment since this "fill-in-the-gaps" test was an attempt to gauge listeners' perceptions of text within a truly polytextual, polyphonic work. Unlike the tests that we later devised (see below), the target words were embedded within coherent text phrases and deployed-in the music of Christopher Fox-in authentic, rather than simulated, polyphonic conditions. However, the methodological problems that arose by using music and text that had already been composed, rather than constructed to satisfy specific, testable parameters, were too great. (A further test method, developed in response to these problems, is currently being presented as an adjunct to Clerks' performances and some comments on this are made below.)

Considering all these methodological challenges, it is a tribute to the patience and tenacity of composer Christopher Fox and the scientific team that we managed to develop tests that could be conducted in a live performance environment and yet that also satisfied robust scientific requirements. If Tales from Babel achieved nothing else, it reassured us that useful and consistent data sets can be generated in circumstances far less controllable than the laboratory allows; and in this respect it has been gratifying that our Test Two (sentences sung against background noise) has yielded results that replicate the findings of similar speech-against-noise tests. (For the results of Test Two, see Heinrich, Knight, and Hawkins 2015.)

Observations about the results of Test Three (where pairs of voices sing different texts) can only be preliminary at this point; but it seems clear that the success or failure of listeners in sticking to a particular stream and resisting the temptation to switch to the other stream appears to be, at best, loosely

9 Analysis of this test can be found in an initial poster paper, Heinrich et al. (2012) at http://www.talesfrombabel.co.uk. 
related to linguistic sense. In a parallel, laboratory-based study, Sarah Hawkins remarks on the importance of word segmentation in the intelligibility of sung text and on those melodic and rhythmic features that aid or hinder the perception of word divisions (Hawkins et al. 2015). A similar finding may arise from more detailed study of the Test Three data; and one might surmise that, just as word segmentation is important for the intelligibility of individual words, so the comprehension of whole sentences of text, when sung, relies in part on the perception of how those sentences are segmented and organised. As a demonstration of this, consider texts that require for their accurate comprehension the articulation of punctuation or recognition of subclauses. It is rare for composers to be able satisfactorily to mimic the inflections that, in speech, render commas, colons, and parentheses comprehensible to the listener. The choral literature is littered with examples, of which three-familiar to anybody who works as I do in the Anglican choral tradition-will suffice. The music to the Christmas carol "God rest you merry, Gentlemen" makes no provision for the comma and thus is routinely misunderstood as "God rest you, merry Gentlemen." Parentheses create greater challenges for the composer. Hubert Parry, in his well-known setting of Henry Vaughan's poem "My soul, there is a country" for instance, struggles with the lines "He is thy gracious friend / And (O my soul awake!) / Did in pure love descend, / To die here for thy sake." More complete is the failure of the hymn "Just as I am," setting words by Charlotte Elliott, to manage the parentheses and enjambment in the lines "Just as I am (Thy love unknown / Hath broken every barrier down)," though in this instance there is a charming self-awareness in the writing as the barrier of the line ending is exuberantly breached. Settings of more extended poetic forms such as the sonnet often suffer both from the problem of convoluted grammatical structures and from the inability of music to sustain the listener's engagement in the wide arc of a couplet's rhyming scheme-an arc that, when set to music, might only come to rest after many bars of music. This inability is our inability. As listeners, it seems we do not hold on to poetic line as we hold on to musical line. No wonder, then, that audiences at song recitals have their heads in the programmes, however clear the declamation of the singer might be. One might sympathise with the frustration of the performer who must look out at rows of heads buried in programmes, but in order for audiences fully to comprehend the text (rather than simply perceive accurately a succession of syllables) they have to engage with that text on the page.

One other trend that appears in the results from Test Three, and that is supported by these parallel laboratory tests, suggests that harmonic profile-consonance and dissonance- has a more profound effect on the success rate than the coherence or incoherence of the texts. When a voice pair sings in consonant counterpoint, listeners are more able to follow the target stream successfully to the correct ending than when it sings in dissonance. While the ramifications of this observation lie outside the remit of the present essay, I should confess that this result also came as a surprise. David Huron's (2001) innovative and groundbreaking study of voice-leading principles in (textless) counterpoint, which demonstrates that listeners' perception of individual melodic 
streams is less acute when those streams are moving in synchronous, parallel consonances, might encourage us to think that texted counterpoint operates in the same way. So long as voice-leading coherence is maintained within each part, a hypothesis extrapolated from Huron's study might suggest that dissonant contrapuntal lines would be more amenable to perceptual streaming than consonant lines and that therefore the texts attached to those dissonant lines would be more separable and intelligible. However, the frequency masking that occurs between consonant intervals does not, in this case, hinder text intelligibility as much as dissonant intervals do. One possible explanation is that our relative lack of familiarity with dissonant harmony means that more of our attention is involved in making sense of or processing the musical information, distracting us still further from the message of the text; but this must remain conjecture at this point.

One further set of tests, presented to live audiences by the Clerks, remains to be discussed; tests designed to return us to the question that initiated Tales from Babel, namely text intelligibility in polytextual motets from the late Middle Ages. The purpose here has been to gain further insights that may furnish hypotheses testable in the rigorous manner of our earlier work. The test material consists of segments of a three-voice polytextual motet from the early fifteenth-century Old Hall Manuscript. The two upper voices, the "motetus" and "triplum," which are fully texted in the original, are here supplied with newly composed English texts whose themes and functions-prayer and saintly hagiography-reflect those of the original. The lower voice ("tenor") vocalises on the vowel sound $/ \mathrm{u} /$. Participants are asked three types of multiple-choice question based on the sung texts: factual questions (e.g., "what is the name of the Saint?"), integrative questions (e.g., "for what quality was the Saint revered?"), and a question asking which three words (from a list of seven) they hear. The information required to select the correct answer is distributed between the two voices, thus making it a divided-attention task. Participants are given two "warm-up" tests involving only one texted voice, and they are given time to read the questions in advance of each test. Yet even with expectations primed, audiences find such tests extremely challenging. Listeners reported switching attention from one voice to another, sometimes quite swiftly, but did not claim the ability to attend to the two simultaneously; and the evidence from their test scores appears to back this up. Of course, while our audience on this occasion consisted of musically literate students and teachers, their lack of exposure to fourteenth-century motets may mean that they do not qualify as "literati." ${ }^{10}$ Yet the same has been reported, informally, at all performances of the Lament for Michael Jackson, in which Anneliese Emmans Dean's texts create many connections across voices, obvious and subtle. It would seem that, when consciously attending to text in polytextual works, we are serially monogamous.

Possibly the most significant observation from this latest test involves one further element. Into each texted voice part is inserted an anomalous phrase:

10 The term used by Johannes de Grocheio for those most suited to appreciating the motet. See Grocheio $(1973,26)$. 


\section{Edward Wickham}

a name that breaks crudely into the sense and register of the text, for example "Teach us, we pray, to cherish the Gospel, keep Wayne Rooney its testimonies and follow the path which there is set for a virtuous life. Amen." The intention here is to mimic that most intriguing aspect of the cocktail party problem, whereby we are able, even across a crowded room, to pick out our own name, a piece of gossip, or something registrally or lexically dissonant. At this task, participants have failed spectacularly, most being unable even to hear the name in the context of the single-voice "warm-up" test. Two conclusions might be drawn from this: that listeners, no doubt partly because of the challenge of the test itself, are attending not just imperfectly but selectively to the sung texts; and that without the intonational nuances that might, in normal conversation, accompany an anomalous phrase-for instance intensified articulation-the perceptual cues alerting us to the phrase are lost. Music, following its own rhythmic and melodic patterns, flattens the effect.

Any test of this kind necessarily lays a responsibility to listen on audiences that they may not be used to or appreciate. An enlightening observation from our pilot presentations came in answer to the question of whether it was important for the listeners to hear the words in choral music: many respondents replied that it was not or was merely of marginal importance. In an amusing diversion from the main thrust of the project, we conducted a social network-based campaign to elicit the best and most absurd "mondegreens": those mishearings of song lyrics, often illogical and sometimes inappropriate, which retain hold in our consciousness long after we have been disabused of our error. The term "mondegreen" was coined by the American writer Sylvia Wright, from a mishearing she had fallen prey to as a child: "They have slain the Earl O'Moray / And laid him on the green," ran the folk song, misheard as "Lady Mondegreen." Classic examples of mondegreens include the correspondent to the Guardian some years back who reported having heard the lyric in the Beatles' "Lucy in the Sky with Diamonds" that runs "the girl with kaleidoscope eyes" as "the girl with colitis goes by" and my own recollection of the famous aria from Handel's Semele: "Where'er you walk, call girls will fan the glade."

Quite apart from the obvious fact that mondegreens reveal how easy it is to mistake one lyric for another-and to be prompted to mishear lyrics- the fascination of mondegreens lies both in the tenacity with which they remain in the memory and in their unquestioning acceptance by those who hold them. It supports the evidence provided by our pilot audiences that hearing and understanding text is not necessarily an important element in the appreciation of texted music. That, as we sing along to a particular favourite song, we unashamedly and credulously reprise lyrics that make no sense reveals a perceptual lethargy with regard to text intelligibility and coherence when music is involved.

On the level of phonemes and syllables, the reasons why text intelligibility might be compromised when sung are related to techniques of vocal production and have been studied in various ways. Collister and Huron, for instance, 
have tested the intelligibility of individual words in a number of familiar musical contexts, studying the effect of repetition, rhyme, and melisma, among other things (Collister and Huron 2008; Johnson, Huron, and Collister 2014; Wickham 2014). (One of the many interesting results is that there appears to be little difference between classical operatic singers and music-theatre singers in these kinds of test.) The work of Fine and Ginsborg makes clear that professional musicians and the musically educated are more adept at hearing text in music than those with little musical training (Ginsborg, Fine, and Barlow 2011). Our own Test Two can be seen as complementing these studies with an experiment in a live performance environment.

The requirement for singers in the classical/conservatoire tradition to distort vowel sounds, particularly when singing at the extremities of the register, has obvious repercussions for text intelligibility, as does the conflation or partial suppression of consonants, which, in some forms of singing or in certain instances, is regarded as idiomatic. What to do with vowels sung on a melisma, how to treat diphthongs, where to place consonants in choral music: these and many more issues are determined as much according to cultural, acousti$\mathrm{cal}$, and physiological considerations as to consideration of text intelligibility. One example is the different approach to diphthongs in classical and popular traditions: singers working in the former will invariably extend the first vowel sound in a diphthong until the very end of the note, before moving to the second, while singers in popular and folk idioms will exploit the timbral shift of the diphthong in various ways, including moving onto the final vowel sound early. However, beyond these examples of genre-constituted adjustments to text pronunciation in singing, we need to consider how phonemes, perceptible and intelligible as individual units, are built up into comprehensible semantic units: words, phrases, and sentences.

It is widely recognised in the field of linguistics that the framework for understanding speech is provided not through the linear accumulation of phonemic signals, but by the patterning of phonemes in rhythm and pitch sequences. The relationship between large-scale linguistic patterns and individual phonemes is immensely rich and complex, such that the pronunciation of a particular consonant can be discernibly altered by a linguistic environment that may stretch considerably further than just neighbouring words. ${ }^{11}$ This ability to perceive patterns in speech is what facilitates our understanding of conversations conducted against background noise that could obscure syllables and entire words. The imperfections of the signal are pieced out by our thoughts. When text is set to music, this sophisticated patterning of rhythm and pitch is largely erased and overwritten by the uniform, controlled sequences of pitch and rhythm stipulated by melodic lines. The minute cues to understanding that we perceive in speech are obliterated, and we must work that much harder to make sense of the words we hear.

11 See, for example, Hawkins (2003); Coleman (2003). 
If the intelligibility of text in music, especially polyphonic music, is as severely compromised as this project is suggesting and if audiences for vocal music, whether consciously or unconsciously, switch off or at the very least turn down their perceptual engagement with text when it is sung, then one might reasonably ask the question, why bother? Why in fact does so much vocal music- the vast majority of it-involve text? This is a question that could involve musicologists, biologists, psychologists, and sociologists, and there is surely a multiplicity of answers.

Yet it is not so broad or abstract a question that it does not affect the way that singers, and particularly choral singers, go about their business. In all forms of choral music, the text plays an important role, even if that role is not primarily that of textual exposition or declamation. Text can be structural and articulatory, timbral and acoustical. It provides a stimulus to singers to phrase lines in a particular way, and for the listener (at least unconsciously) it provides a focus and definition to the sound. When a work, conceived originally for instruments, is adapted for choir, it invariably takes on a text as well, one that reflects the perceived emotional ambition of the work. Thus Barber's Adagio for Strings, adapted by the composer himself, takes on the text of the Agnus Dei, whose tripartite structure serves to delineate musical sections. A purely vocalised adaptation of the Adagio would lack the extra gravitas imparted by the Agnus Dei text, but more importantly it would lack a certain timbral focus and structural definition.

To see how text can articulate musical material on the local level and even help shape larger-scale forms, we might usefully return to repertories of vocal music from the late Middle Ages and early Renaissance that are presented in the sources with little or no text. The early fifteenth-century song repertory, for instance, is most commonly presented by scribes with a texted upper voice and untexted lower voices-a phenomenon that has provoked much discussion and inspired divergent performance traditions for many decades. ${ }^{12}$ Yet in almost all encounters with fifteenth-century musical sources for vocal music one has to deal —as editor and/or performer - with partial texting that requires interpretation or "realisation." How this realisation might be effected is best understood by experiencing it oneself: singing in a polyphonic ensemble from sources of the period. The challenge of rendering the music with appropriate text is one of the many enjoyable aspects of singing from facsimile; it reinforces the sense that the polyphonic ensemble operates as a unit from which a collective interpretation of the music emerges.

Strategies for how text might be apportioned when singing from imperfectly texted sources will instinctively differ depending on the scribe and the nature of the text. In the case of Walter Frye's Missa Flos regalis, which the Clerks rehearsed, performed, and recorded using the unique Brussels MS 5557 source, the technique is straightforward (Frye 1999). ${ }^{13}$ In most of the mass, the scribe provides clear text underlay for the upper voice only; the lower parts are left

12 The arguments are surveyed in Leech-Wilkinson (2002, 88-156).

13 A facsimile of the Brussels source is reproduced as Wegman (1989). 
with only text incipits. But so clear is the superius underlay that it requires only the other ensemble members to follow the top part, and cues for where to start new text phrases can be easily discerned. While this process of texting "on the fly" might at first be disconcerting, it requires no more sophisticated ensemble skills than the alignment of bowing in a string ensemble, particularly for singers who are as familiar with the words of the Latin mass as singers of the fifteenth century must have been.

This alignment of text between parts can equally operate within parts, and the lack of text in this type of polyphony need not imply one-to-a-part performance. It is quite possible for two or three singers to coordinate, with no extravagant physical gesture, changes of syllable and breaths. This kind of "entrainment" is an acknowledged feature of skilled ensemble music making, and it could apply as much to the disposition of text as it does to the coordination of dynamic gesture and changes of tempo. Significantly, the scribe of the Frye mass in Brussels 5557, despite leaving so much of the text realisation to the discretion of the performers, still uses specific, dismembered, text syllables to create alignment between the voices at particular moments. Thus, at the end of the duos that open the Agnus Dei, the scribe provides for the bass and tenor the syllable "-ta" to be sung at exactly the same time as the duetting superius and contratenor reach that syllable at the end of "peccata." The syllable, meaningless on its own, provides a performance cue, a moment of alignment. We find many similar instances in early Renaissance polyphony, where voice parts that have retired from the polyphony, re-enter for the final chord, on (one assumes) the same syllable as is being sung by the other parts ("-sis" of "excelsis," or "-son" of "eleison" are common examples).

Elsewhere I have written about how polyphony of this period tends to combine "composed" text-music alignments, often to create particular timbral gestures, with passages of unspecified texting (Wickham 2011). These features might occur in all parts simultaneously-as when the name of a patron or dedicatee is proclaimed in straightforward homophony, before the parts subside into polyphony-or might occur in parallel, as when the text of the Credo is declaimed against a polyphonic background in Ockeghem's eccentric Credo "Sine nomine." In these instances, composers appear consciously to be deploying text as an acoustical device, concentrating syllables in as intelligible a way as possible so as to place them in the auditory foreground. In some cases the impulse to do this might come from some rhetorical or theological ambition; but, crucially for our discussion of the non-semantic role of text in music, in other cases it would seem as if the reason is to highlight a purely musical feature.

The polyphony of the late Middle Ages will surely provide a valuable resource for the exploration of these questions in the future, questions that take us beyond the traditional discussion of text and its deployment in terms of semantic appropriateness in the service of some external function, be it rhetorical, symbolic, or liturgical. The work of Warwick Edwards has consistently sought 


\section{Edward Wickham}

to remind us of the use of text in this repertoire not as a predetermining factor in the structuring of the polyphony but as an articulatory reinforcement of gestures and structures that are first and foremost musical (for example, Edwards 2011). We need, in short, to stop thinking about music as setting text and think instead about text "setting" music. Cross-referencing the emerging literature on music as a tool for social entrainment will also provide useful insights (for example, Cross 2009). One can imagine, for instance, a study of ensemble dynamics in a scenario where a group of singers is tasked to realise a piece of untexted or partially texted polyphony through rehearsal and performance. Comparison between a work texted in this way and the same work texted by a single editor might tell us something of the different functions of text as expressed in "bottom-up" and "top-down" approaches to its deployment.

As for following up on the work of Tales from Babel, the next step must be to devise tests that will enable us, perhaps little by little, to get a better grasp of how listeners comprehend text in real-life performance scenarios. So complex are the interactions and interferences between phonemes in normal speech that we can hardly conceive of analytical tools and experimental designs fine enough to pick apart the various elements that go to enhance or distort text intelligibility when set to music. And yet this is not just about the complexities of language articulation at the phonemic level; it is about the high-level patterning of language and the ways in which this patterning enables understanding. More fruitful than laboratory-based studies of specific phonemic incidence and the intelligibility of particular words might be an approach that acknowledges and incorporates the concert hall, with its flattering or distorting acoustics, and the performance experience, rustling pages, irritating coughs and all, as essential protagonists in the experience of hearing texted music. Thereafter, the myriad other environments in which music is experienced might come under similar scrutiny. ${ }^{14}$ For sure, test results from such environments might be cross-checked under laboratory conditions; but ultimately our understanding of what singers are singing about is derived as much from the patterns of expectations created by the musical event and brought to it by individual listeners as from the way a composer has composed the song and the singer articulates it.

\section{ACKNOWLEDGEMENTS}

The observations contained in this paper, while ultimately my own responsibility, are the result of close collaborations with Christopher Fox, Sarah Hawkins, Antje Heinrich, and Sarah Knight, to whom I owe a great debt of thanks. I would also like to thank the singers of the Clerks for their unfailing patience and expertise in realising this project in so many memorable concert performances.

14 The relationship between performance spaces and the way in which we perceive and consume music has become a rich topic of discussion. See, for example, Born (2013). 


\section{REFERENCES}

Bent, Margaret. 1993. "Reflections on Christopher Page's Reflections." Early Music $21(4): 625^{-33}$.

. 1997. "Polyphony of Texts and Music in the Fourteenth-Century Motet: Tribum que non abhorruit/Quoniam secta latronum/ Merito hec patimur and Its 'Quotations.”' In Hearing the Motet: Essays on the Motet of the Middle Ages and Renaissance, edited by Dolores Pesce, 82-103. New York: Oxford University Press.

Born, Georgina, ed. 2013. Music, Sound and Space: Transformations of Public and Private Experience. Cambridge: Cambridge University Press.

Brungart, Douglas S., Brian D. Simpson, Mark A. Ericson, and Kimberly R. Scott. 2001. "Informational and Energetic Masking Effects in the Perception of Multiple Simultaneous Talkers." Journal of the Acoustical Society of America 110 (5): 2527-38.

Cherry, E. Colin. 1953. "Some Experiments on the Recognition of Speech, with One and with Two Ears." Journal of the Acoustical Society of America 25 (5): 975-79.

Cherry, E. Colin, and W. K. Taylor. 1954. "Some Further Experiments upon the Recognition of Speech, with One and with Two Ears." Journal of the Acoustical Society of America 26 (4): 554-59.

Coleman, John. 2003. "Discovering the Acoustic Correlates of Phonological Contrasts." Journal of Phonetics $31(3-4)$ : $35^{1-72}$.

Collister, Lauren B., and David Huron. 2008. "Comparison of Word Intelligibility in Spoken and Sung Phrases." Empirical Musicology Review 3 (3): 109-25.

Cross, Ian. 2009. "The Evolutionary Nature of Musical Meaning." Musicae Scientiae 13 (2): 179-200.

Dillon, Emma. 2012. The Sense of Sound: Musical Meaning in France, 1260-1330. New York: Oxford University Press.

Edwards, Warwick. 2011. "Word Setting in a Perfect Musical World: The Case of Obrecht's Motets." Journal of the Alamire Foundation 3 (1): $5^{2-75}$.

Frye, Walter. 1999. Missa Flos regalis. On Brussels 5557-Plummer: Missa Sine nomine; Walter Frye: Missa Flos regalis. Performed by the Clerks' Group and Edward Wickham.
Signum Classics, SIGCDo15, compact disc.

Ginsborg, Jane, Philip Fine, and Chris Barlow. 2011. "Have We Made Ourselves Clear? Singers and Non-singers' Perceptions of the Intelligibility of Sung Text." Proceedings of the International Symposium on Performance Science, edited by Aaron Williamon, Darryl Edwards, and Lee Bartel, 111-16. Utrecht: European Association of Conservatoires (AEC).

Grocheio, Johannes de. 1973. Concerning Music. Translated by Albert Seay. 2nd ed. Colorado Springs: Colorado College Music Press.

Hawkins, Sarah. 2003. "Roles and Representations of Systematic Fine Phonetic Detail in Speech Understanding." Journal of Phonetics $3^{1}$ (3-4): $373-405$.

Hawkins, Sarah, Kate Honey, Sarah Knight, and Antje Heinrich. 2015. "Intelligibility of Sung Words in Polytextual Settings." Paper presented at the International Congress of Phonetic Sciences, Glasgow Conference, 2015.

Heinrich, Antje, Sarah Knight, and Sarah Hawkins. 2015. "Influences of Word Predictability and Background Noise on Intelligibility of Sung Text in Live Concerts." Journal of the Acoustical Society of America (forthcoming).

Heinrich, Antje, Edward Wickham, Christopher Fox, Ian Cross, and Sarah Hawkins. 2012. "Stream Segregation of Speech in Live Concert-Hall Performances of a 6-Voice Choir." Poster paper presented at the British Society of Audiology Conference, Nottingham, 2012.

Huron, David. 2001. "Tone and Voice: A Derivation of the Rules of Voice-Leading from Perceptual Principles." Music Perception 19 (1): 1-64.

Johnson, Randolph, David Huron, and Lauren Collister. 2014. "Music and Lyrics Interactions and Their Influence on Recognition of Sung Words: An Investigation of Word Frequency, Rhyme, Metric Stress, Vocal Timbre, Melisma, and Repetition Priming." Empirical Musicology Review 9 (1): 2-20. 


\section{Edward Wickham}

Kalikow, D. N., K. N. Stevens, and L. L. Elliott. 1977. "Development of a Test of Speech Intelligibility in Noise Using Sentence Materials with Controlled Word Predictability." Journal of the Acoustical Society of America 61 (5): 1337-51.

Leech-Wilkinson, Daniel. 2002. The Modern Invention of Medieval Music: Scholarship, Ideology, Performance. Cambridge: Cambridge University Press.

Lewis, Joe L. 1970. "Semantic Processing of Unattended Messages Using Dichotic Listening." Journal of Experimental Psychology 85 (2): 225-28.

Page, Christopher. 1993. Discarding Images: Reflections on Music and Culture in Medieval France. Oxford: Oxford University Press.
Wegman, Rob C., ed. 1989. Choirbook of the Burgundian Court Chapel: Brussel, Koninklijke Bibliotheek MS. 5557. Peer, Belgium: Musica-Alamire.

Wickham, Edward. 2011. "Realization and Recreation: Texting Issues in Early Renaissance Polyphony." Journal of the Alamire Foundation 3 (1): 147-66. . 2014. "From Speech to Song: A Response to Johnson, Huron and Collister on the Interaction of Music and Lyrics.” Empirical Musicology Review 9 (1): $25^{-28 .}$

Zayaruznaya, Anna Anatolievna. 2010. "Form and Idea in the Ars Nova Motet." PhD thesis, Harvard University. 


\title{
From Clockwork to Pulsation
}

\section{Music and Artificial Life in the Eighteenth Century}

\author{
Lawrence Kramer \\ Fordham University, New York
}

What is experimentation in music? Like most such terms, this one is very loose. But it seems fair to say that music is experimental in the broadest sense when something about it is obviously set outside mainstream practice. Experimental music asks if something unlikely can become the stuff of art. Can one write intelligible polyphony in forty or even sixty independent parts? Thomas Tallis's motet Spem in alium (1575) and the piece that may have inspired it, Alessandro Striggio's Missa sopra Ecco si beato giorno (1565-66), say yes-in forty and sixty voices respectively. Can a classical symphony end with a choral movement? We all know the answer to that one. Is it possible to compose with "twelve tones related only to one another"? Schoenberg's Five Piano Pieces (1923) show how to do it. Can two pairs of hands clapping generate a polyphony that makes music of bodily sound? Steve Reich's Clapping Music figures out a way and produces a mirror inversion of Tallis's and Striggio's polychoral tapestries. Examples abound in every phase of musical history, in every musical culture and subculture. Many of these experiments end by generating new norms. Experiment, for better and worse, is the childhood of routine.

There is, however, another, more historically bounded form of musical experimentation with quite a different logic. This type belongs to the dawning age of empirical science, pre-eminently in the eighteenth century, and it operates on the same basic principle as the classical scientific experiment. That principle is the setting up of an artifice to reveal a natural truth or law. Explicit musical experiments on this model form a small but significant part of the era's musical canon. Just as significantly, the experimental attitude persists in implicit form throughout the period and continues into the early nineteenth century. In most cases, the aim of the experimental venture is to test whether music can simulate life. It remains to be seen just why that should be so. To begin addressing that question, we might consider a famous musical experiment, one that

DOI http://dx.doi.org/10.11116/9789461661883.cho7 
its composer explicitly described as an attempt to do something new. But to conduct our own experiment we will have to try to un-hear this music, which has been so encrusted by its own fame that its import has largely been lost.

Largely, but not entirely. The slow movement of Haydn's Symphony No. 94, composed in 1791, contains a loud chord in the wrong place-a shocking surprise, as the symphony's familiar nickname announces. First we get a sing-song, tick-tock statement of a naive theme, or more exactly a theme too naive to be believed; then we go ka-boom (see figure 1).

According to Daniel Chua (1999, 92), "The surprise ... is in the human hand that comes to tamper with the self-wound motions that the music signifies with its clockwork tune. Conscious life ha[s] seeped into the score, and the mechanical [is] merely a play of signs for the organic."' The continued force of Haydn's vital outburst became unexpectedly apparent during the presentation of this paper at the 2013 Orpheus Academy, when technical difficulties prevented me from playing the music. Everyone present knew the tune; someone suggested we sing it together; and I thus ended up conducting an a cappella performance of the first sixteen measures. At the end, several participants redoubled the loud "surprise" with resounding whomps! on the tables in front of them. Everyone in the room knew what was coming, but everyone seemed to make a spontaneous leap from formal measure to bodily exuberance. A more convincing or more pleasurable "argument" would be hard to imagine.

But why, we might ask, identify the organic with a sudden jolt? Does it come to life like the creature in Mary Shelley's Frankenstein? Does it subdue the mechanical or does it just make an entrance, take a bow, and leave? How does the physical force of a blow translate into the expressive force of conscious life? How do you hold conscious life in your hand?

A good answer rests with what comes after the initial surprise. This movement is a theme and variations, and it follows Haydn's usual custom of preserving the theme almost intact in each variation while letting change come from alterations in expression and/or the addition of ornaments. In the "Surprise" Symphony this procedure leads to a grand climax in the third and last variation in which the whole orchestra blares out the no-longer-mechanical theme with big contributions from the brass and timpani-the biggest contributors to the "surprise" chord (figure 2). The organic manifests itself as a surge of intensity. It is less an expression of consciousness than of bodily excitation at the limit of consciousness. The effect of the music is ultimately more quantitative than qualitative. And it is precisely in its changeable intensity that the music achieves its most lifelike effect and most clearly links its expressiveness to the simulated presence of an animated subjective being. The era understood living bodies as bodies of excitation. For well-informed listeners in 1791, we might speculate, Haydn's "surprise" would really have been an announcement of something that should be no surprise at all but, on the contrary, a demonstration of the latest scientific models of the principles of life. The music would be one experiment amid a long parade of others.

1 For more on this topic, see also Leguin (2005, especially 182-89); Christensen (2002). 


\section{From Clockwork to Pulsation}
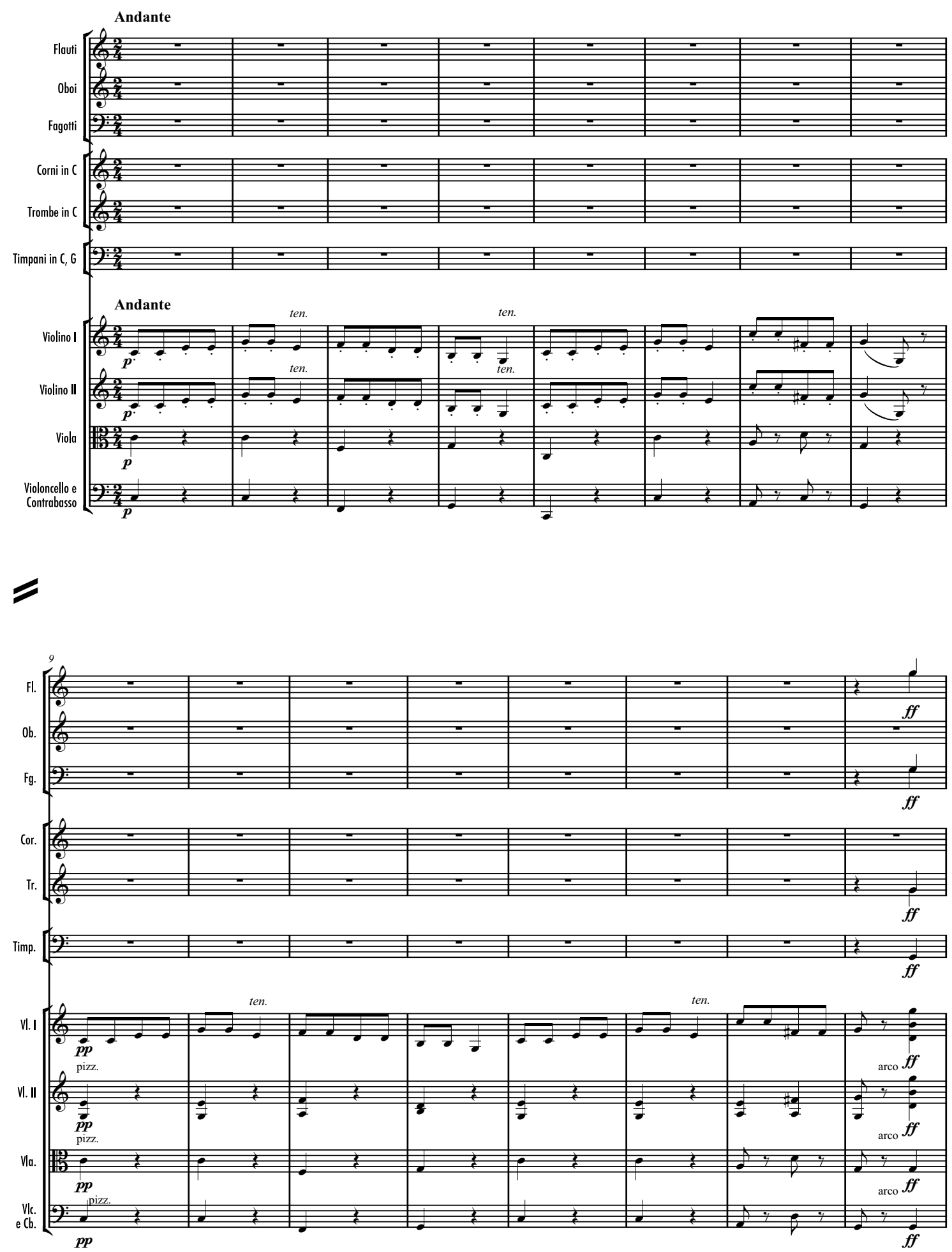

Fig. 1. 

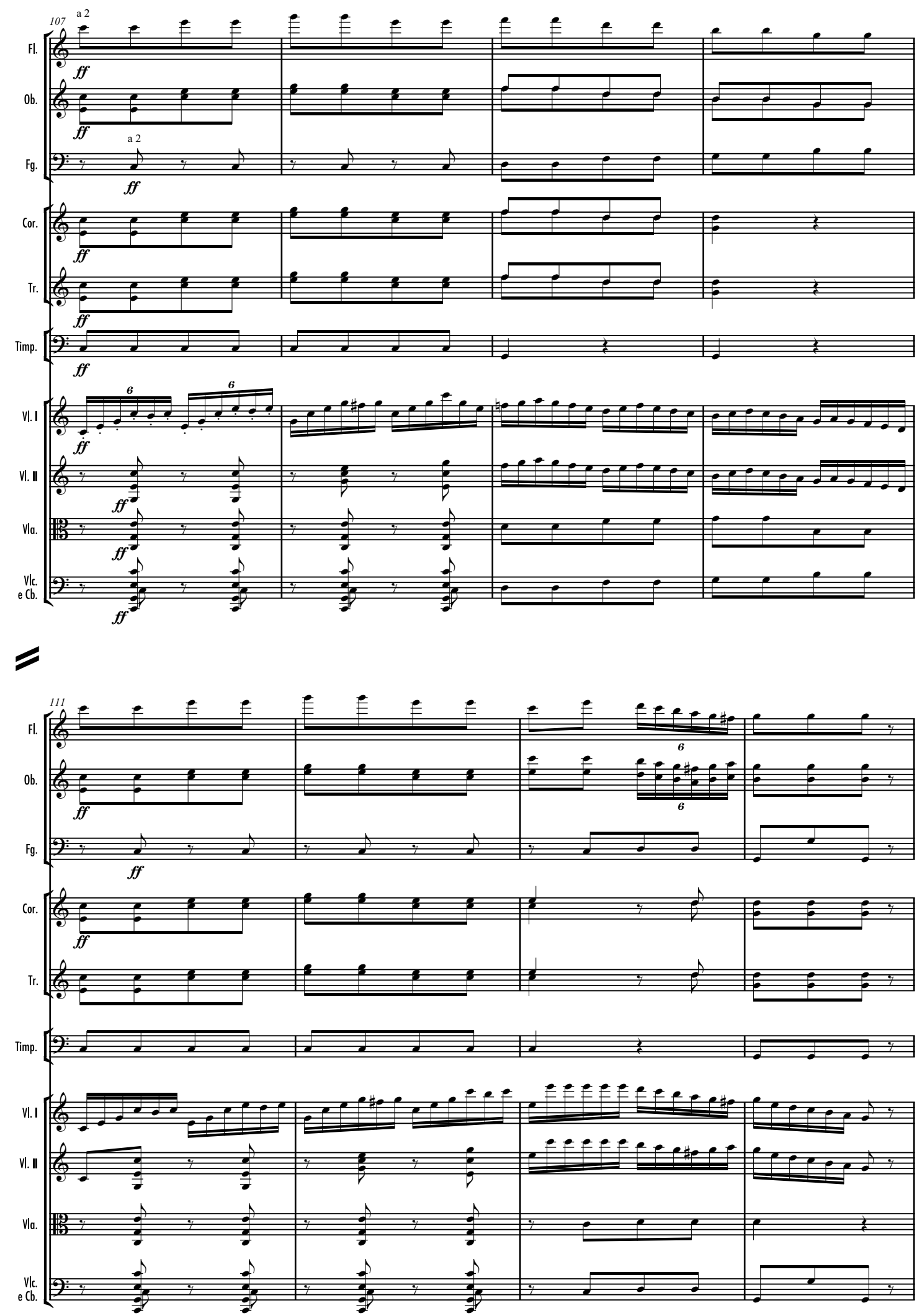

Fig. 2.

150 
In supposing as much, we encounter an important ambiguity. The life simulated in the "Surprise" Symphony slow movement is interior life; that is, it is not life observed from without but life revealed as if from within. This interiority, however, is divided along lines that had vexed European thought about life since Descartes. It is both a mental and a bodily interiority, and its existence raises the perennial question of how to bridge the gap between mind and body, or more exactly of how to experience the music's implicit claim that its sonority in performance does bridge that gap.

How, indeed? My answers to that question will themselves be somewhat experimental; they will emerge from a free oscillation-in light of what follows, "vibration" might be the better term-between free speculation and the close examination of historical artefacts. In the end, I will be suggesting not only ways to hear life and the body in an important segment of the classical repertoire but also ways in which such music draws us - again in light of what follows "drives us" might be the better term-to revisit historical forms of embodiment kept alive primarily by that repertoire itself.

By the end of the eighteenth century, music has become the privileged instrument for the expression of inner truth. The historicity of this observation is now widely acknowledged. Music was not always that way; then it was; whether it remains so is an open question. In any case people since that shift of musical episteme have customarily said that music expresses their deepest feelings, or feeling at its deepest. But they can do so only because a certain music, and a certain way of hearing it, teaches them that their feelings, and they themselves, have this depth to be expressed. Poetry acquires the same power when regarded, at roughly the same time, as the language of feeling. But poetic feeling is always overtly mediated whereas musical feeling is supposedly direct; its mediations are remarkably susceptible to effective concealment. Culture privileges the deep self by assigning it certain qualities that substantially overlap the material qualities of music, and music thus becomes a principal source of the self's qualitative palette.

In particular, two dimensions of music came to the fore to render it an ideal metaphor for the self as deep and inward. Both of them occupy a prominent place in Hegel's Lectures on Aesthetics. The first of these is that music arises through vibration. The vibratory evokes the immediacy of subjective presence and its rich, endlessly communicable resonance; vibration is primal sympathy. The "oscillating vibration" of sound, writes Hegel, becomes the material of music when it is fashioned as a note, and in music "the ear . . . listens to the result of the inner vibration of the body through which what comes before us is no longer the peaceful and material shape but the first and more ideal breath of the soul" (Hegel 1975, 2:890). Although the breath of the soul is ideal, it manifests itself by disturbing the inert sleep of a material reality. Music is matter rudely awakened-matter that quivers as a result. Soul irritates body. (The meaning of that sentence will become clear shortly.)

The second dimension of music that encourages inwardness is the excess of music over language, which becomes the independence of music from language. Among Hegel's many formulations of this trait the best known is prob- 
ably the observation that "especially in recent times music has torn itself away from a content already clear [that is, made clear by a text] ... and retreated in this way into its own medium" (ibid., 2:899). The retreat to the extra-linguistic produces the duality of being and expression, apperception and articulation, sense and signification, which constitutes the modern self as the never achieved and never achievable reconciliation of these opposites.

Neither of these dimensions survives in the dominant forms of latter-day popular music, in which vibration becomes an overpowering external force and music is identified with song. In this sense music anticipated the dissolution of the deep self or subject brought about by the cultural and technological changes of the new millennium. At the same time music also anticipated the reformulation of this lost mode of subjectivity as a mode of fiction and fantasy - which, one might say, it had always been, only without the knowledge of its condition.

Formally, to revive Michael Polanyi's model of tacit knowledge, a certain "classical" music can model interiority to interiority itself (as Hegel says it does) because the connotative and affective interplay that this music provokes is known tacitly, and hence experienced inwardly, when we attend from that interplay to the music (Polanyi 1967, 301-25). We perceive the music but experience the interplay; we hear the sound but feel its meaning. The coalescence of these terms installs music in the larger field of subject-formation and changes the field by so doing. In the nineteenth century, this process becomes focused especially on the piano, which emerges as one of the principal technologies of subjectivity, a part of its material as well as its social apparatus. At the same time, however, the piano imparts a certain finitude, a certain delimitation, on the subjective process-a tendency that finds its countervailing force and mirror reversal in the transcendental fantasies of the romantic orchestra. In the first half of the twentieth century popular song maintained its ties to this mode of subjectivity only to abandon it later. Jazz improvisation has kept the ties to date, but at the cost of no longer being a mode of popular music.

But what does the field of modern subjectivity consist of? How can it be theorised? And what does it have to do with Enlightenment experiments in artificial life? Here is a possible sketch:

The eighteenth century witnessed a shift in social organisation based on the increasing division of labour and the separation of life from work. According to Niklas Luhmann $(1995,239)$, this "functionally differentiated" form of society—in other words, modern society—subordinates "[the] human being's full complexity" to the effective performance of specialised tasks. Social and personal life cease to coincide; system replaces hierarchy; function supersedes tradition (ibid., especially 176-254; see also Schulte-Sasse 1989). The modern subject is both the creature and the victim of this social order. To counter its own tendency toward dispersal, the modern form of society compels the subject to comply with regulation by a thoroughly administered and rationalised public sphere. Not only human action but life itself submits to a "disciplinary" regime-the term is Michel Foucault's-grounded in the constant possibility of supervision and surveillance (Foucault [1977] 1979, 170-230). As an inevita- 
ble consequence, the subject tends to reserve or withhold a part of itself for private, unrationalised pursuits and fantasies. ${ }^{2}$ Another consequence is that subject formation can proceed only if the subject represses or renounces several of its most basic possibilities of power, pleasure, and knowledge. Insofar as this repression fails or is refused, the field of subjectivity is incomplete or unachieved. Deep subjectivity, which in this context is the same thing as subjectivity per se, cannot come about without loss.

Late twentieth-century theorising tended to conceive this condition by speculating on-and celebrating-alternative subjectivities and discourses, ways of being and saying that arose in resistance to the normative subject, not least from within that subject. Foucault $(1978,159)$, for example, famously spoke of "bodies and pleasures" as an alternative to the modern subject ruled by the "austere monarchy of sex." The idea was above all to refuse the burdens of tight self-possession and mastery of self and other, together with the consequences of these principles in rigidity of character, isolation, and emotional sterility. The self as norm was an idol to be dethroned. (The idol also incorporated hostility to racial, social, sexual, and gendered others, but that is a story told too often to need retelling here.)

Nonetheless, the resistance to subjective rigidity had rigidities of its own, and the model of resistance may have outlived its usefulness. It seems more promising now to think of the process of constructive repression as itself normative in the sense of being unavoidable, and therefore as playing a primary role in the formation of subjectivity. The subject, in short, is not yet itself until after its initial project of self-definition goes off course in some way. Identity is a detour. Questions of both definition and valuation become immensely more complicated and more interesting in this new framework.

For many thinkers from Nietzsche on-a list that runs from Freud to Foucault, Lacan to Žižek to Butler-the dynamic of the modern subject is determined by a dark spot at its core. ${ }^{3}$ This is an essential kernel of opacity. It consists of the subject's ability to exceed or inability to be fixed by any symbolic system. This indeterminacy is initially felt as a lack, an alienation, even where it also is felt as a privilege. Ironically, we are now all familiar with the idea that we are strangers to ourselves.

What can be said about this dark contraction? What can we make of it and what does it make of us?

Among the responses it provokes, two are especially pertinent to the texture of experience. First, there is the identification of the subjective kernel with a principle of invisibility or secrecy that discloses itself, but never fully, in brief bursts of expression (some true, some false; it is hard to tell the difference). The self lurks behind the curtain except when it flashes across the stage. Second, there is the identification of the innermost kernel as an absence more effective than presence. The kernel is an ungovernable and unsignifiable singularity that somehow marks the orderings and significations that constrain but cannot

2 For more on this tendency, with particular reference to the music of Schubert, see Kramer (1998, 27-38).

3 To cite just the last two, see Žižek (1991); Butler (2005). 
contain it. This perennially vanishing subject marks its relationship to symbolisation by enigmatic inscriptions within or across symbolic surfaces-on which, so to speak, the subject signs itself with its initials, an act it can repeat endlessly.

The modern subject is thus a force rather than a form. It is a subject known only by what its actions leave behind. This formulation-force rather than form-is the hinge linking the history of modern selfhood to Enlightenment life science. Although I have characterised it thus far in quasi-Cartesian terms, in relation to thinking, this subject is inconceivable without a certain body-a body that is linked to the subject-mind in more than Cartesian terms. The force of the subject originates in organic force, as variously conceived from the seventeenth through the early nineteenth centuries. The names for that bodily force vary greatly, from sheer mechanism to animal magnetism to electrical impulses - the last, of course, being the most accurate. The means of representing the same force is, more often than one might think, musical; and music, in turn or in return, begins at the same time to assume the character of the forces it helps to represent. Initially this exchange is a product of musical experimentation, but it quickly, perhaps as early as the first decade of the nineteenth century, becomes assimilated to the concept of music itself.

Bound up with these developments and in good measure a motor for them is the emergence of the concept of drive, the idea-hardly thinkable before the eighteenth century - of an impersonal force impelling the person qua subject to irrational acts and attachments. Drive is the active and often negative embodiment of subjective interiority, its logical counterpart and inevitable evil twin-to invoke another trope invented a few years after Haydn's symphony was composed: the alter ego, the double that betokens a structural characteristic, the representation of depth as a splintered surface. The history of drive, and the socio-psychological disposition it produces and rationalises, is yet to be written. That history perhaps begins with a certain quantification of life processes that emerges in the mid-eighteenth century, beginning with theories of the life force and gaining reinforcement in the nineteenth century from both popular misunderstandings of Darwinian evolution and the psychophysical measurement of perception as a product of mechanical forces. Quantity becomes a criterion of experience, perhaps in reaction to the public need for restraint and control; intensity becomes a value, and even an object of desire. There is less than a world of difference between Goethe's identification of blessed yearning, seelige Sehnsucht, with the self-immolating desire of the moth for the flame and Walter Pater's urging a "hard gemlike flame" on his readers as the condition to which they should self-immolatingly aspire ([1893] 2005, 154). It was Pater, of course, who also, regrettably, said that all art aspires to the condition of music (ibid., 90).

Pater's remark affords us a moment of reflection. All this examination of subjectivity and Enlightenment life science may seem a long way from music, but we already know from Haydn that it is anything but that. Insofar as music produces excitation in the subject; insofar as music turns attention and identification toward a course of action that does not wish to be broken before it reaches its appointed end; insofar as music, which always wants to be heard 
again, makes that end a release from which a new beginning may follow, music participates in the production of drive. The latter-day forms of the backbeat and the rhythm track even package "drive" for safe use at work or at home. Music emerges from eighteenth-century thought about life to become one of the chief models of drive. This is especially true of the strongly directional tonal music of the later eighteenth and most of the nineteenth centuries. Without music, without this particular music, drive would perhaps have been unthinkable, or at least (as far as its qualitative dimension goes) unimaginable. This is a hyperbole, but perhaps only a little one.

Besides, as I noted earlier, Enlightenment representations of life and life force had repeated recourse to music. A comparison of nervous excitation to the vibration of strings was a commonplace of the era; its most famous contemporary formulation appeared in David Hume's A Treatise of Human Nature in 1739: "If we consider the human mind, we shall find, that with regard to the passions, 'tis not of the nature of a wind-instrument of music, which in running over all the notes immediately loses the sound after the breath ceases; but rather resembles a string-instrument, where after each stroke the vibrations still retain some sound, which gradually and insensibly decays" (2.3.9, Hume [1739-40] 1888, 440-41). Hume, of course, is a philosopher, not an experimenter, but similar figures also turn up in the writings of scientists. This is from Jean-Joseph Ménuret de Chambaud's article "Pulse" in the Encyclopédie of Denis Diderot and Jean Le Rond D'Alembert: "If one wishes to form an idea of the way in which the organs contribute to the movements and contractions of the arteries.... Imagine strings radiating out from each organ ... the uniform tension of these strings will produce a combined effort... Such are the varieties of the pulse which an able observer strives to grasp" (quoted in Wolfe 2012, 24).

In 1769 Diderot wrote a trio of dialogues on the question of life and collected them under the title D'Alembert's Dream. Drawing liberally on the work of his friend Théophile de Bordeu, a physician, researcher, and leading theorist of the life force who appears as a fictionalised character in two of the dialogues, Diderot described the human subject as a sentient musical instrument, in particular a sentient harpsichord (clavecin): "Suppose there is a harpsichord with sensitivity and a memory. Tell me if it won't know and repeat on its own the melodies you have executed on its keys. We are instruments endowed with sensibility and memory. Our senses are so many keys which are struck by nature surrounding us and which often strike themselves. And there we have, in my judgment, everything which goes on in an organic harpsichord like you and me" (Diderot 2014).

I should mention that Diderot's sentient harpsichord remained unknown in its own time, since D'Alembert's Dream was not published until 1830. The importance of this instrument for us, however, depends not on when it was made public but when it was conceived, and conceived in relation to a widely circulating body of tropes, including Hume's. In another work that did see the light in Diderot's lifetime, the Letter on the Deaf and Dumb of 1751, a similar analogy 
appears, this one based on the vibrations of a bell—although strings are still attached:

If I had to explain [the] system of the human understanding... I should say, "Consider man as a walking clock; the heart as its mainspring, the contents of the thorax as the principal parts of the works; look on the head as a bell furnished with little hammers attached to an infinite number of threads which are carried to all corners of the clock-case. Fix upon the bell one of those little figures with which we ornament the top of our clocks, and let it listen, like a musician who listens to see if his instrument is in tune: this little figure is the soul..."

I could pursue my analogy still further, and add that the sounds produced by the bell do not die away at once, but have some duration; that they produce chords with the sounds that follow, and the little figure that listens compares them, and pronounces them harmonious or dissonant; that memory, which we need to form opinions and to speak, is the resonance of the bell; the judgment, the formation of chords; and speech, a succession of chords. (Diderot 1916, 185-86)

The passage is notable for not being content simply to indicate an analogy between music and the life force; the analogy demands detailed elaboration, a verbal blueprint for the construction of the musical soul. The demand points to the features that distinguish eighteenth-century versions of what is actually an ancient trope: their emphasis, first, on the materiality of the instrument on both sides of the metaphor and, second, on the instrument's capacity to vary in levels of intensity. The quantitative factor depends on the workings of a mode of memory associated with sympathetic vibration, a process assigned to the sentient harpsichord in D'Alembert's Dream but here given to the bell. The duration of the sounds is sustained by the relationship between one vibration and another, and Diderot takes pains to indicate that the results vary in intensity depending on the number of strings that are struck: "If many of these little threads are pulled at once, the bell will be struck several times, and the little figure will hear several notes simultaneously. Imagine that there are some of these threads that are always being pulled" (ibid., 185).

Like a clockwork, however, the analogy winds down, and Diderot ends it by rebuking himself for indulging in metaphors rather than thinking philosophically. But neither here nor in D'Alembert's Dream does he ever surrender his metaphors or even try very hard to replace them. In that respect he is acting in harmony with his friend Bordeu. In his own magnum opus of 1751 , Bordeu explains the scientific necessity of metaphors with specific question to sensibility, his candidate for the vehicle of life force:

[Sensibility] is one of these metaphors I must be allowed; those who examine these questions closely know how difficult it is to explain oneself when speaking of the force that directs with such precision a thousand singular motions in the human body and its parts; one does not even know what terms would serve to express certain movements in plants or even certain properties of minerals.... [Georg] Stahl claimed that the soul directed everything in the animal body. However that may be, one can state that all living parts are directed by a self-preserving and ever-vigilant force; does this [force] in certain respects belong to the essence of a portion of 
matter or is it a necessary attribute of its matter's combinations? Once more we cannot claim to give more here than a way to conceive these things, metaphorical expressions, comparisons. (Bordeu 180o, 311-12n1, my translation) ${ }^{4}$

Much later, the necessity of such verbal invention was not lost on Freud, who called drives "mythological entities, magnificent in their indefiniteness" ([1964] 1965,84 ) and held that without figurative language "we could not describe [depth-psychological] processes ... at all, and indeed we could not have become aware of them" $(1961,72)$. One might remark in passing that Bordeu might just as well be talking about how to describe music, a point worth keeping in mind when we eventually turn back to Haydn and move ahead to Beethoven.

Diderot's little figure of the soul qua musician is introduced as one of those metaphors the thinker must be allowed, in part because of the figure's other resonances. The image of the little musical homunculus is consistent with "evolutionary" explanations of life in the eighteenth-century sense of "evolution," meaning that life forms germinate from a condition of "pre-formation" that contains all their properties in miniature. But the image is even more closely connected to another contemporary representation of the life force, the construction of humanoid machines that are moving, if not walking, clockworks, and that are therefore something more than mere machines.

These automata, or androids as they were called even at the time, were widely known and admired. Five of them became especially famous, and of these three were musicians. The other two were a writer and a draftsman. This distribution of roles suggests that for an automaton to simulate human life in eighteenth-century terms it was necessary for the figure to replicate a process of signification or expression; and the fact that music took pride of place among these processes suggests that what the figure had to demonstrate was the outcome of both nervous and muscular energy - what the era called sensibility and irritability, respectively. That demand, in turn, meant that the android could not merely reproduce music in the manner of a music box, but actually had to perform the music as a human player would.

The first of the musical androids met all these criteria. Built in 1737 and presented to the French academy in the next year before being put on public view-for a price-this automaton was the creation of a prolific inventor, Jacques Vaucanson. (Vaucanson's most famous android was actually a duckbut that is a story for another day. He was also the inventor of the automated loom.) The Academy was very impressed by Vaucanson's work, and so was the

4 This passage occurs in a footnote to the statement "La secrétion se réduit donc à une espèce de sensation, si on peut s'exprimer ainsi." The footnote reads: “C'est encore ici une de ces métaphores qu'on doit nous permettre; ceux qui examinent ces questions de près, savent combien il est difficile de s'expliquer lorsqu'il s'agit de parler de la force qui dirige avec tant de justesse mille mouvemens singuliers du corps de l'homme et de ses parties; on ne sait pas même de quels termes on doit se servir pour exprimer, par exemple, certains mouvemens des végétaux et même certaines propriétés des minéraux; ... Stahl ... prétendoit que l'ame dirigeoit tout dans le corps animal; quoiqu'il en soit, on peut dire que toutes les parties qui vivent sont dirigées par une force conservatrice qui veille sans cesse; seroit-elle à certains égards de l'essence d'une portion de la matière, ou un attribut nécessaire de ses combinaisons? Encore un coup, nous ne prétendons donner ici qu'une manière de concevoir les choses, des expressions métaphoriques, des comparaisons." 
public, and so was Voltaire. The source of their admiration was a life-sized figure dressed in pastoral costume. Seated on a large pedestal that concealed the clockwork mechanism inside, this figure could play the flute. The spectator could see the player's fingers move, watch him as he breathed into the instrument, and hear him perform any of twelve different melodies. In other words, the figure demonstrated both sensibility and irritability, nervous expressiveness and muscular action. If it was not actually alive, it was the next best thing.

The other musical automata were an organ player and a dulcimer player, both of them female figures in courtly dress. They were built on a smaller scale than the flute player, although the organist was still in a sense life-sized, since she is a girl rather than a woman. ${ }^{5}$ Unlike Vaucanson's, these automata still exist, and they still work. The organist was built between 1768 and 1774 by members of the Jaquet-Droz family, Swiss jewellers whose firm is still in business; the writer and draftsman are also Jaquet-Droz automata. The dulcimer player was constructed by the clockmaker Peter Kintzing and the cabinetmaker David Roentgen in 1784; it was bought by Marie Antoinette in 1785 and presented shortly afterward to the Academy of Sciences. Like Vaucanson's flute player, the dulcimer player had a repertoire; she could play eight melodies. But what was most important about her in relation to the simulation of life is that while she played her head turned and her eyes moved, so that the motion of her arms, simulating muscular action, was accompanied by evidence of sensibility. The Jaquet-Droz organist was similarly designed, and she was more lifelike than the dulcimer player in one respect: like Vaucanson's flute player, the Jaquet-Droz organist breathes.

The combination of sensibility and irritability in these androids gave them a status somewhere between a machine and a life form, something for which the era had no effective vocabulary. The same combination carried over to music when music coupled subjectivity, universally understood at the time as the expression of feeling, with the projection of imaginary bodies. The possibility of this coupling depends above all on quantity, the variation of intensity that has acted as a leitmotif in this paper. We will shortly sample the operation of shifting intensities in Haydn and Beethoven, but before doing so we need to say a little more about the scientific basis of the process.

The primary question driving eighteenth-century theories of life was whether life could be explained as the product of purely physical mechanism or whether an additional factor, some identifiable version of the ancient idea of a life force, was necessary. In general, the trend favoured the vitalists over the mechanists, but by the end of the century the argument was effectively made obsolete by the discovery that nerve impulses were carried by electricity. The distinction between sensibility and irritability nonetheless survived this change, and the association of the primary vital powers with electricity even enhanced the metaphorical identity between the life force and power in its most naked form. The fluctuation of intensity could stand as both a synonym for and a symbol of life.

5 For detailed accounts of all these androids, see Riskin (2003). 
The interplay of sensibility and irritability gave this fluctuation its specific form. For vitalists such as Bordeu, sensibility was primary; the power to feel was vested in the nerves and formed a controlling centre for the other vital functions, each of which had its own independent life. But among those functions irritability stood out; and for Bordeu's chief rival, Albrecht von Haller, the principles of sensibility and irritability were equally primary and life emerged as the functional product of their combination or, in other words, of the interplay of feeling and action. As Haller developed his model, however, he gradually came to the conclusion that the distinction between sensibility and irritability was porous-a conclusion driven in part by his own discovery that only organs supplied with nerves were capable of feeling (see Wolfe 2013, 148-60). Feeling and action could not be disjoined. The muscles and nerves together were both the vehicles and the objects of the general flow of force that constituted life. The emergence of drive in relation to the composition of life is thus implicit throughout the era-and the same thing applies to composition with tones.

Non-scientists were quick to take up the ideas of Haller and others and to apply them to other areas of concern, including music. Johann Gottfried von Herder was a notable example. He had a strong interest in physiological science and frequently applied its findings to his own subjective life. He had studied Haller's Physiological Elements of the Human Body (1757-66): and in Kalligone, an essay on aesthetics published in 1800 , Herder showed it. The passage is a Diderot-like dialogue between A and B:

\author{
A. A blow disturbs a body; what message does that body's sound communicate? \\ B. "I have been disturbed; my members are consequently vibrating and eventually \\ coming to rest.”

\begin{abstract}
A. Is that what they say to us?
B. Every fibre of our being is capable of responding; our ear, the hearing-chamber of the soul, is ... an echo-chamber of the finest kind....
\end{abstract}

\begin{abstract}
A. What about sounds that get louder or softer, faster or slower, sounds that rise or fall, that are increasingly or decreasingly intense?...

B. As every involuntary reaction ... to music proves, these all produce similar responses. The tide of our passions ebbs and flows.... At one moment the passions are intensified, at another they are aroused now gently, now powerfully ... [T] he way they move varies in response to every melodic nuance, and every forceful accent.... Music performs on the clavichord within us which is our inmost being. (Herder 1988, 188-89)
\end{abstract}

Herder begins with irritability and passes smoothly to sensibility through the medium of music - not just sound, but music, performed in the concert hall of the ear and on the keyboard of the self. (Herder could not have known Diderot's similar image, which makes this appearance of the sentient keyboard all the more, well, striking.) The blow with which Herder's account begins is the conceptual equivalent of Haydn's "surprise" chord. The element of violence 
that the blow introduces stems from the discourse on irritability, and the link may be one reason why some of the most prominent musical experiments with life processes come in agitated, minor-key movements. That is the case with the two examples to which we will now turn.

Haydn's Keyboard Sonata in C Minor (Hob. XVI:20), published in 178o but probably composed around 1772 , is the first of Haydn's sonatas to call for frequent sharp contrasts between forte and piano, an indication that the instrument it was conceived for was, precisely, the fortepiano, not the harpsichord, and that the kind of shifting intensity celebrated by Herder thirty years later was the order of the day. Such shifting is close to the music's only law; it drives everything from forte and piano attacks on alternating single notes to large-scale scrambling of the order of events as one section follows another. But three of the music's features seem especially close to the play of irritability and sensibility. Appropriately enough, they are more revealing if they are not taken up in the order of their appearance.

In medias res, then: at about the midpoint of the first section, the movement settles for three measures on the dominant of $\mathrm{E} b$, its secondary key. The right hand melody on this plateau fills out each of the first two measures with a long note followed by a flurry of rapid triplets; the accompaniment for the last two measures puts its own triplet flurries under the melodic long note and its own long note under the melodic triplets. The process begins forte but falls to piano with the left-hand triplets in the third measure. At that point Haydn gives the right hand a cadenza, an unmeasured Adagio written out in small notes, with no accompaniment except for a ghost of one tied over in the left hand. The cadenza consists primarily of the triplet flurries, now slow where before they were fast, and soft where before they were loud. The passage dies away into a condition of complete passivity: a moment in which single tones emerge one by one in different registers and linger under a fermata in a state of sensuous arrest. It will take the intrusion of another blow to get the music going again.

Haydn thus moves, like Herder, from irritability to sensibility, though with urgency rather than latent violence. But as both Haller and Herder observed, the reverse is equally likely; the sensibility roused by a blow may incur other blows to arouse it further, willingly or not. Haydn's sonata does just that at the end of the exposition, when a continuous stream of triplets in the left hand establishes a steady pulse that anchors a series of little melodic jolts in the right hand. At first the triplets sound piano and readily absorb the jolts, which are scattered. But then the jolts become continuous and forte and they thrust the triplets into an outburst of irritability that brings the section to an unsettled close. The same thing happens again in the recapitulation, leaving room only for a brief codetta in which sensibility sounds stunned. And in the meantime there has been another rise in intensity that sets its signature on the whole movement.

The sonata begins with a pungent figure in dotted rhythm set against scattered broken octaves in the bass. If muscular irritation gives rise to movement, as Haller showed that it does, this combination would be a good candidate for how that process might sound if it were audible. At this point, though, the fig- 
ure is primarily a point of departure; it is only one measure long and we hear it only twice, at the head of the opening two phrases. In the second section it becomes more prominent and correspondingly more intense. It returns to begin the development, where its irritability yields some grotesque gyrations: the figure quickly turns upside down, with the lurching octaves in the treble, and then nearly as quickly flips itself right side up, reasserting its original form with the octaves in the bass but at more than double its original length: twoplus measures.

But it is not done. The recapitulation begins with the figure in its original form, but there is no return to its original one-measure sequel. Instead the figure intensifies its earlier intensification; it returns again more than doubled in length but this time in its inverted form, its octaves rising through the treble to magnify its effect. But then, its effect just is magnification. There is little qualitative change here, but the quantitative change is decisive. Sensibility may return, and the Adagio sound again - those things will happen - but the music will still stagger at the end. (Pianists should perhaps take more note of this. Many of the performances I listened to while working on this chapter seemed bound to an ideal of "classical" restraint in which this music has no interest whatever.)

Beethoven follows a similar trajectory in the first movement of his Piano Sonata No. 5, op. 10, no. 1, composed in 1796 and, like Haydn's, written in C minor. But Beethoven incorporates the violence that Haydn avoids, or, if you prefer, makes explicit the violence that Haydn leaves latent. But this is not so much a dramatic violence as it is the acknowledgment of a physiological principle-though of course these categories do not exclude each other. The music begins with a loud, solitary chord, the kind of noisy shock that Haydn reserved to demolish his pretty little tune in the "Surprise" Symphony. After this things go from bad to worse, but they do so in a certain determined way. The music sounds as if-and keep this as if in mind-it were making a demonstration of the first exchange between A and B in the dialogue from Kalligone: "A. A blow disturbs a body; what message does that body's sound communicate? B. 'I have been disturbed; my members are consequently vibrating and eventually coming to rest." For vibrate the members do, then come to rest-but the blow strikes again; the vibrations resume, they come to rest more slowly, they almost settle down, and then comes another blow, and another, and then another. It seems as if every decrease in intensity were simply creating the potential for an increase, and a sharp one at that. Drive wants to go into overdrive; a surplus of life force threatens to turn destructive. And only twenty measures have gone by.

At this point Beethoven writes out a grand pause, which I will take advantage of to reflect for a moment on what has just been said.

We do not yet have an effective common language to describe the kind of relationship that this music, as presented here, has to the habits of mind, experience, and observation that surround it. It is easier to say what that relationship is not-and the same holds for the Haydn. The music does not depict life processes in Enlightenment terms, nor does it signify them, nor does it imitate them. Instead it acts like the era's androids, only with an imaginary rather than 
a material body: the music makes a demonstration by acting as if it were alive, or, more exactly, as if it were a distillation or sensory realisation of the life force as the era understood it. This as if is neither exhaustive nor exclusive, but once set into motion it is, or should be, hard to ignore. It should have the force of what I have elsewhere called a constructive description, a statement that alters and expands the possibility of perception by attaching itself firmly to the thing it describes. As we know from the language of Herder, Diderot, Hume, and others, actual descriptions of the sort circulated regularly. The era's understanding of life affected music in part because the era's music affected its understanding of life.

But back to Beethoven. After the pause comes a long period of lyrical rest leading by slow degrees to the secondary key of $\mathrm{E} b$, and with it a broad, flowing, confident theme. It is as if the music were trying to settle into a normal rhythm of excitation and repose; the new theme is exactly the kind that ought to have appeared first in a normal sonata movement, assuming there is such a thing, rather than turning up displaced in both position and key. The theme offers us the opportunity to hear it in a kind of virtual polyphony against its physiological basis, and more especially against the potential collapse of its physiological basis. Just past the threshold of audibility lies an abyss of pure drive. The conditions for this or any music to present itself as an untroubled source of pleasure and well-being are not easy to maintain, and we can literally hear as much even while enjoying the vigour and sweep of the melody. It should come as no surprise when more blows rain down near the end of the exposition.

Like Haydn, Beethoven begins the development section by recalling and extending the fraught opening measures; unlike Haydn, he begins the recapitulation by lowering the level of intensity. He allows the initial vibrations to come to rest, omitting the long series of blows and vibrations that precede the grand pause. If a kind of everyday normality has been the goal, we can plausibly entertain the idea that the music has reached it. But Beethoven puts that conclusion in question, or renders it somewhat wishful, by subtly rewriting the series of blows and vibrations that returns near the end of the section. In the exposition, the vibrations do not come to rest but at least they find a common level of unrest; the first three land on the same note before the fourth thrusts up by a third. In the recapitulation the series does more than just fail to settle down; it intensifies. The level vanishes. The first three vibrations land on a series of notes that rise up by semitones; the fourth turns down by a semitone. In the exposition, the notes involved belong to the tonic triad; in the recapitulation the first and third notes are dissonant outliers. Like Haydn, though not in the same place, Beethoven adds nothing substantial but intensity. Qualitative change is minimal; quantitative change takes over.

This relation of quantity to quality is one of several conditions that tend to guide the demonstration of life in the musical culture exemplified by Haydn and Beethoven. If we take their sonatas as exemplary, the other conditions are also fairly evident. Like life itself as conceived by both mechanists and vitalists, the fluctuation in intensity by which music achieves its physiological as if generally arises as the outcome of a heterogeneous action. The action follows a 
discernible logic and generally reaches its peak in the form, not of the different, but of the same repeated at a quantitatively higher level. The resulting simulation makes available an intermediate space between mechanism and vitalism in which the human body and its subjective self-reflection are defined by their capacities of sensibility and irritability in excess of the stimuli that prompt feeling and action. Another name for that excess is drive.

The subject of modernity typically encounters the force of drive in forbidden and/or desired extremes of self-delight and reflective torment, set at equal (but by no means always sustainable) removes from the disciplines of everyday life. "Everyday life" itself is a concept of modernity; in traditional society the only difference between "life" and "everyday" life was the cycle of rituals and festivities that organised the year. The modern everyday world is a space from which drive has been, or ought to have been, excluded, which renders it simultaneously a safe haven and boring trap, normal and inauthentic at once. The modern entertainment industry developed in part to provide fantasies of escape from what Wallace Stevens $([1921] 1954,96)$ called "the malady of the quotidian" to which, however, the satisfied customer returns with strict punctuality. What Adorno called the culture industry is less gratifying and more open to ridicule, because it is based on the impossible domestication of drive-a fantasy in its own right, but a timid one.

This modern tension between drive and the everyday, a tension that in good measure forms the condition of modernity itself, has difficult consequences. Consider the distinctly modern history of self-affirmation by self-destructiveness, something unique to the post-Enlightenment era. If Foucault is right that social power in this era manifests itself as the management of life rather than the punishment of death, then to be healthy, wise, and good is to become something less than an individual. The only way to resist the power exerted on one, to find identity beyond ideology (though that is of course impossible) is to invent what Freud would call the death drive, to make oneself sick, foolish, and wicked. Better death, in Deleuze's words (1990, 160), than the health one is given.

A drive toward that conclusion pulses through Michael Haneke's recent film Amour (2012), which I mention here to suggest that the problems of sensibility and irritability first posed musically at the close of the eighteenth century are still pertinent today, not least because they are still unresolved. The narrative begins in a concert hall, shot from the point of view of the stage; we see only the audience as it assembles, and we do not know what kind of performance is about to start. Then we hear a sudden loud octave on the piano-a musical blow like the one in Beethoven's sonata, another Haydn-like surprise displaced to the point of departure. The music is Schubert's Impromptu No. 1 in C Minor, op. 90, which confronts its initiating moment of raw life force with a contrary expression of sensibility in the form of a funeral march. In so doing, the music provides, in advance, a condensed version of the film's entire narrative. The narrative traces the consequences of a blow to the body, a paralytic stroke, which destroys the body it irritates and leads inexorably to an actperhaps euthanasia, perhaps murder; it is impossible to tell — that might well 
take Deleuze's maxim as its own: better death than the health one is given. At the same time the film associates this music with the intuition of a persistent substrate of vital force, an unextinguished and perhaps inextinguishable sensibility, in Bordeu's sense of the term, which the narrative of paralysis cannot quite overcome. The first thing we see in the film, before the title sequence, is a violent breakthrough into a closed apartment, the narrative equivalent of the forceful octave. The film, like the music, begins with a blow that breaks a seal.

A lot is at stake in that blow. One might argue that modernity has often sought to realign the subject with the pre-symbolic substrate of things-a now secular substrate that in pre-modern culture was uniquely controlled and regulated by the categories of the sacred. The world of the subject has an underlying pulse, a Great Beneath as opaque as the subject itself but nonetheless, to echo Menuret, something that the able observer strives to grasp-above all, perhaps, to hear.

Three approaches might be said to guide this project, above and beyond the large effort of the symbolic order to negate it. These approaches can be epitomised by the three French "maitres" who so heavily influenced the critical theory of the later twentieth century. Lacan, the Freudian ironist, assumes that entry to the pre-symbolic, which he calls the Real, is always barred. Foucault, the covert mystic, seeks a practice of conceptual and corporeal self-transformation by which to open the gates of the never-before-entered Real, a care of the self to come based on "a multiplication and burgeoning of bodies ... the body made totally plastic by pleasure: something that opens itself, that tightens, that throbs, that beats, that gapes" (Foucault 1975-76, as translated in Miller [1993] 1994, 274). ${ }^{6}$ Derrida, the rhapsodist (like Plato's Ion) will not name the Real as such or identify it as any one thing. But he will project the Real as the horizon of the surpluses and supplements that attend all thought, and in so doing he will relive and relieve the Real (playing on relever, Derrida's favoured translation of Hegel's Aufheben) in perpetuity. Derrida recovers the Real in the process of dispersing its traces.

There is no plausible way to adjudicate among these modes of thought, nor do they form an exclusive or up-to-date list. But one can theorise that between the Real "itself" and the innumerable Lacanian objets $a$ that substitute for the Real qua Thing (objets $a$ that all three approaches would agree are illusory and that only the mystical approach posits as possibly other than illusory), there are material venues in which the force of the Real, the force of drive, can be deflected into sensory experience. In the later eighteenth century music became the chief of those venues. It did so in part by making a demonstration of life. Music made it possible to experience the relationship to the Real as something other than mere negativity, in part by giving the negative an affirmation in a Foucault-like spirit of defiance. Such music helped establish intensity as an aesthetic good; it did so by making intensification a compositional principle-a principle still in effect, though no longer as universal as it once

6 As Miller shows, Foucault finds the promise of this "desexualized" utopia in the erotic "ordeal" of S/M: "the slow motions of pleasure-pain" (Foucault quoted in Miller [1993] 1994, 273). 
was. The spirit of defiant life is already perceptible, literally audible, in our C-minor sonata movements by Haydn and Beethoven; and so, especially in the Beethoven, is the temptation to let drive go to its unknown limit. The aesthetic of this music, and much of the music to follow, incorporates the ever-present possibility of inflicting pleasure as a sign of life.

But what life, exactly? I have suggested several times that the project of artificial life in eighteenth-century music has repercussions for the present, but that hardly opens the door to simple appropriations; much too much has changed. Perhaps it is time to revisit the topic with fresh ears and a different set of concepts. In an era when the life of intelligent machines is basic to everyday experience and people unreflectively use mobile phones as prosthetic sense organs, some new forms of simulation could hardly be avoided. How might an experiment in lifelike music sound today?

I tried to supply one of many possible answers to that question in my piano quartet Pulsation, composed in 2010-11 and premiered at the 2013 Orpheus Academy where this paper was presented. But I will not try to act as my own interpreter; I don't think composers should pretend to be the oracles about what they do. So instead, suffice it to repeat here the programme note at the head of the score.

\begin{abstract}
The title Pulsation is a literal description of what happens in this single-movement work for piano quartet, but it also alludes to a famous passage from William Blake:

For in this Period the Poets work is done: and all the Great

Events of Time start forth $\&$ are conceivd in such a Period

Within a Moment: a Pulsation of the Artery.

The basis of the music is virtually unbroken eighth-note pulsation in the strings at the heartbeat tempo of quarter note $=72$; departures from the pulsating texture are highly marked. The piano plays both with and against this pattern, which it continually varies and transforms and ultimately draws into a state in which time slows and even, for a moment, seems to stop. A further layer of pulsation is added by the repetition of whole segments at irregular intervals throughout. The string tessitura is deliberately restricted, the upper strings in particular being kept largely away from their higher registers. The aim is to create a complex, acoustically rich musical space in which listeners, led by the piano (which in a sense speaks for their listening as a form of imagination), can become wholly absorbed and perhaps catch an echo of the fundamental pulsebeat in which Blake located the origin of creative energy.
\end{abstract}

So ends the note. To what extent is the pulsebeat it refers to a nostalgic metaphor? When so much of the music we hear every day is a work of engineering, is it still possible to hear even purely "live" music as a simulation of life? Loud chord, anyone? 


\section{Lawrence Kramer}

REFERENCES

Bordeu, Théophile de. 180o. Recherches anatomiques sur la position des glandes, et sur leur action. Nouvelle éd. Paris: Brosson; Gabon. First ed. published $175^{1}$ (Paris: Quillau).

Butler, Judith. 2005. Giving an Account of Oneself. New York: Fordham University Press.

Christensen, Thomas. 2002. "Bemetzrieder's Dream: Diderot and the Pathology of Tonal Sensibility in the Leçons de clavecin." In Music, Sensation, and Sensuality, edited by Linda P. Austern, 39-56. New York: Routledge.

Chua, Daniel K. L. 1999. Absolute Music and the Construction of Meaning. Cambridge: Cambridge University Press.

Deleuze, Gilles. 1990. The Logic of Sense. Translated by Mark Lester with Charles Stivale. Edited by Constantin V. Boundas. New York: Columbia University Press. First published 1969 as Logique du sens (Paris: Éditions de Minuit).

Diderot, Denis. 1916. Letter on the Deaf and Dumb. In Diderot's Early Philosophical Works, translated and edited by Margaret Jourdain, 158-218. Chicago: Open Court. First published 1751 as Lettre sur les sourds et muets ([Paris]).

- 2014. "Conversation between

D'Alembert and Diderot." D'Alembert's Dream (Le Rêve D'Alembert). Translated by Ian Johnston. Accessed 6 January 2015. http://records.viu.ca/-johnstoi/ diderot/conversation.htm. Written 1769; published in Mémoires, correspondance et ouvrages inédits de Diderot (Paris: Paulin, 1830).

Foucault, Michel. 1975-76. "Sade, sergeant du sexe." Cinématographe 16: 3-5. . (1977) 1979. Discipline and Punish: The Birth of the Prison. Translated by Alan Sheridan. New York: Random House. First published 1975 as Surveiller et punir: Naissance de la prison (Paris: Éditions Gallimard). This translation first published 1977 (New York: Pantheon). - 1978. The History of Sexuality, Volume I: An Introduction. Translated by Robert Hurley. New York: Random House. First published 1976 as Histoire de la sexualité 1: La volonté de savoir (Paris: Éditions Gallimard).
Freud, Sigmund. 1961. Beyond the Pleasure Principle. Translated and edited by James Strachey. Rev. ed. New York: Norton. First published 1920 as Jenseits des Lustprinzips (Vienna: Internationaler Psychoanalytischer Verlag). - (1964) 1965. New Introductory Lectures on Psychoanalysis. Translated and edited by James Strachey. New York: Norton. First published 1933 as Neue Folge der Vorlesungen zur Einführung in die Psychoanalyse (Vienna: Internationaler Psychoanalytischer Verlag). This translation first published 1964 (London: Hogarth Press).

Haneke, Michael, dir. 2012. Amour. London: Artificial Eye, ART o57BD, Blu-ray disc.

Hegel, Georg Wilhelm Friedrich. 1975. Hegel's Aesthetics: Lectures on Fine Art. Translated by T. M. Knox. 2 vols. Cambridge: Cambridge University Press. First published $1835^{-} 38$ as Vorlesungen über die Aesthetik, edited by Heinrich Gustav Hotho (Berlin: Duncker und Humblot).

Herder, Johann Gottfried von. 1988. Kalligone [excerpts]. In Music and Aesthetics in the Eighteenth and Early Nineteenth Centuries, edited and translated by Peter le Huray and James Day, abridged ed., 188-92. Cambridge: Cambridge University Press. Kalligone first published 1800 (Leipzig: J. F. Hartknoch).

Hume, David. (1739-40) 1888. A Treatise of Human Nature. Edited by L. A. SelbyBigge. Oxford: Clarendon Press. First published 1739-40 (London: John Noon).

Kramer, Lawrence. 1998. Franz Schubert: Sexuality, Subjectivity, Song. Cambridge: Cambridge University Press.

Le Guin, Elisabeth. 2005. Boccherini's Body: An Essay in Carnal Musicology. Berkeley: University of California Press.

Luhmann, Niklas. 1995. Social Systems. Translated by John Bednarz, Jr. with Dirk Baecker. Stanford, CA: Stanford University Press. First published 1984 as Soziale Systeme: Grundrißeiner allgemeinen Theorie (Frankfurt am Main: Suhrkamp). Miller, James. (1993) 1994. The Passion of Michel Foucault. New York: Doubleday. First published 1993 (New York: Simon and Schuster). 


\section{From Clockwork to Pulsation}

Pater, Walter. (1893) 2005. The Renaissance: Studies in Art and Poetry. Mineola, NY:

Dover. First published 1873 as Studies in the History of the Renaissance (London: Macmillan). Republication of the 4th ed. (London: Macmillan, 1893).

Polanyi, Michael. 1967. "Sense-Giving and Sense-Reading.” Philosophy 42 (162): 301-25.

Riskin, Jessica. 2003. "Eighteenth-Century Wetware." Representations 83: 97-125.

Schulte-Sasse, Jochen. 1989. "The Prestige of the Artist under Conditions of Modernity." Cultural Critique 12: 83-100.

Stevens, Wallace. (1921) 1954. "The Man Whose Pharynx Was Bad.” In Collected Poems, 96. New York: Knopf. First published 1921 (New Republic 28 [354]: 74).

Wolfe, Charles T. 2012. "On the Role of Newtonian Analogies in EighteenthCentury Life Science: Vitalism and Provisionally Inexplicable Explicative Devices.” Academia.edu.
Accessed 6 January 2015. https:// www.academia.edu/1569763/ On_the_role_of_Newtonian_ analogies_in_eighteenth-century_life_ science_Vitalism_and_provisionally_ inexplicable_explicative_devices. Draft of a chapter published in revised form in Newton and Empiricism, edited by Zvi Biener and Eric Schliesser, 223-61 (New York: Oxford University Press, 2014).

___ 2013. "Sensibility as Vital Force or as Property of Matter in Mid-EighteenthCentury Debates." In The Discourse of Sensibility: The Knowing Body in the Enlightenment, edited by Henry Martyn Lloyd, 147-70. Cham, Switzerland: Springer.

Žižek, Slavoj. 1991. "Grimaces of the Real, or When the Phallus Appears." October 58: 44-68. 


\section{Chapter Eight}

\section{The Inner Ear}

\section{An Interview with Leon Fleisher}

Peabody Conservatory of Music, Baltimore

Curtis Institute of Music, Philadelphia

[This interview was prepared by the Orpheus Institute research fellows Paulo de Assis, Joost Vanmaele, and Alessandro Cervino and was conducted by Paulo de Assis on 20 November 2008 as a part of the Orpheus Research Festival 2008. A period for questions from the audience followed the formal interview; although, unfortunately, we cannot identify the questioners, we have transcribed the exchanges because they were so informative.]

ORCiм: We would like to start with three quotations and one question. The first quotation stems from Theodor Leschetizky [1830-1915], who is said to have said to Artur Schnabel (when becoming his teacher) that "you will never be a pianist; you are a musician"implying a gap between pure music and music as played by an instrumentalist in its concrete, technical rendering. Artur Schnabel [1882-1951], himself a composer, deplored the separation of composer from performer that had become the norm since the late nineteenth century. He once said (and here is our second quotation) that he felt only attracted to music "which is better than it can be performed," suggesting an ideal state for musical works that would be independent from their acoustic realisation or from their manual materialisation through the performer. In this same direction, you also stated that "Suddenly I realised that the most important thing in my life wasn't playing with my two hands: it was music." These three quotations all share the idea of a separation between music as an abstract, autonomous entity, and music's particular renderings in the here-and-now of performative contingencies. In your opinion, to what extent do you think a musical work remains somehow "utopian," i.e., impossible to really be rendered through concrete performance?

LEON FLEISHER: This is a very legitimate question but, in a sense, I think it is answered by the three quotations that you read. The challenges of a great piece of music are internal. The Mozart A-Minor Rondo, no matter how well or how beautifully you play it, always offers new possibilities, other new awarenesses. That's the earmark of a masterpiece. And I think that's what Schnabel meant by saying that he was only interested in playing that music that he felt was better than could be played. He felt, I think, that the challenges of something like

DOI http://dx.doi.org/10.11116/9789461661883.cho8 
a Tchaikovsky concerto, with its octaves, is susceptible, or can be resolved by what he called "seating capacity." You know, you sit long enough and you'll get faster and faster octaves-if that's what you are interested in. And that was not his interest. Today, it would seem to me, there are many young people who, unfortunately-well, "unfortunately" ... I don't know ... There is a certain joy, a kind of joie de vivre (if one can use a cliché like that), in being able to race around the keyboard and do extraordinary things. It is athletic, it is invigorating, it's good for the muscles; but if pursued as the main goal it would seem to me more appropriate that you wind up with a circus-where they do extraordinary things, physically. And I think that does not have much to do with the making of music. I think the distinction lies there.

Another important topic for the ORCiM community has to do with editions of music. In the words of Alfred Brendel (2001,25), "every generation of musicians is unconsciously influenced by the editions with which it has grown up." Schnabel made a technical-interpretative edition of Beethoven piano sonatas. This edition, with its copious footnotes, gives a very good image not only of his understanding of Beethoven but, moreover, of his deepest concepts about piano playing and aesthetics. In a recent interview (Fleisher and Stewart 2004) you revealed that your first recording of Schubert's B, Sonata (D. 960)—made fifty years ago - had an enormous "clinker," due to a printed wrong note in the edition you were working with. In that context you said, "the editions that were available then were somewhat lacking." Do you think that music editions can change our perception of musical works?

Oh yes, absolutely! And not just in terms of wrong notes or text mistakes. I think it is terribly important to get as close as possible to the express written intention of the composer. And those editions that are "ameliorated" by an editor who does not distinguish (generally through a change in print) between his suggestions and what the composer has written are worthless editions because you end up playing the editor, not the composer. So finding what is known as an Urtexteverybody knows this, I think-is what is vital. I know, for example, Henle is a very respected edition, but Henle's Chopin for me is terrible because Chopin oversaw the publication of various editions-the English edition, the French edition, the German edition. I am not sure if he oversaw Carl Mikuli's edition, which is most reliable; and, in addition, he very often made little adjustments depending on who the student was. I have a sense that if there was a very pretty student, he would make it a little bit easier... But the Henle Chopin edition chooses on its own, without any reference to which edition it is following. It makes its own choice; and, for my taste, this is usually one of the more uninteresting choices. Whereas the idea that was started by the Paderewski editionwhich was until that time the most comprehensive and the most informative (now you have most Polish editions with voluminous footnotes saying where their choices come from) - the wonderful thing about the Paderewski edition is that it not only told you where it came from but it also showed all the other possibilities. It showed what the other editions of a work had. 
I think that probably one of the first people to do that was Schnabel with the Beethoven sonatas, which is an extraordinary publication. Schnabel, in effect, tried to put on paper-in kind of primitive terms - what we find in the music: everything that he had learned about the piece in his whole career, in his whole life. So, in a way, reading the Schnabel edition of the Beethoven sonatas is like a lesson. His remarks are in different print, instantly recognisable as not being from Beethoven. Everything that Beethoven wrote is in ink and bold print. You can tell what is Beethoven and what is not Beethoven.

Now we would like to focus on your own artistic work. When you start a new piece do you have an idea in advance that then, through practice, you try to realise, or is it through the working process that the idea is going to emerge? Or is it a combination?

It is a combination-I can't help. It's quite extraordinary, and we don't really realise-even experienced and seasoned performers-we don't really realise how we make little adjustments for physical reasons, adjustments to the instrument, and we try to justify these adjustments with a musical rationale. So I find most advisable, before you ever take the piece to the instrument, sit down in a comfortable chair and read it! And make certain basic decisions, certain basic choices, as you read the music, as you begin to understand the structure, how it's written, even insofar as imagining certain orchestral instruments playing through some materials. Our problem-or, better, our biggest challenge-is that all the notes are equally black. So we have to decide what is important and what is not important. We have to decide what is filler and what is essential. If we can make most of these choices before we go to the instrument we already have a sound in our inner ear. And most important, because-as I mentionedwe made little adjustments to accommodate the instrumental problems, most important is to establish a pulse for the piece.

Much has been said about the connection or the relationship between music and mathematics. I find that, in a sense, a kind of primitive literature. I think music is far more related to physics, because music passes in time, music is a horizontal activity, it goes from point $\mathrm{A}$ to point $\mathrm{Z}$, but the point $\mathrm{Z}$ is two minutes away, or one and a half hours away, as in a Mahler symphony. So it is movement. And therefore, it is subject to all the forces that movement is subject to-to drive, to momentum, etc. When you go around a corner you have a scale that goes up and comes down again, or that goes down and comes up again: it's subject to centrifugal or centripetal force. It's like when you drive a car: you turn your wheel to the right but your body goes to the left. And when you go around a corner there is that sense. And it's not like a typewriter-takataka-taka - unless the music demands that. So one of the big challenges of the piano, in spite of it being the best instrument there is, is that we are faced with producing the sense of movement. It's interesting: every other instrument, every string instrument from violin to double bass, every wind or brass instrument from piccolo down to tuba depends on movement to make it sound. You stop the bow and the sound stops; you stop blowing air and the sound stops. All these movements are horizontal movements: the blowing of air, the moving 


\section{The Inner Ear}

of the bow. How are we going to produce this irresistible sense of movement and direction horizontally by a totally vertical activity? You put little keys up and down; they don't go sideways, they go up and down, exactly $3 / 16$ th of an inch. That's our challenge.

One thing you just mentioned seems to be extremely important: working away from the piano, sitting down and reading a score. This is something you very often refer to in your interviews...

It's a way of working music: one makes music on the piano, one makes music on the kazoo, one makes music-wherever, wherever your choice of instrument is. There is nothing special or sacred about the piano. What is special and sacred is music.

\section{Another thing you mentioned is the "inner ear."}

Oh, $\mathrm{ja}$ ! This is something I learned from Schnabel. You have to hear before you play. You have to have in your inner ear exactly what it is you want to sound like. If you don't have a goal for every note that you play, what happens is an accident. You just have a series of accidents, and once you start you just try to somehow relate them or make them organically generate what comes afterwards. No, you have to hear everything that you play before you play. It's really an extraordinary activity, it's a kind of schizophrenic activity, if it is done well. Because I think we are three people in one: we are person A who hears before they play, we are person B who actually does the playing, who puts down the keys, and we are person $C$ who sits a little bit apart and listens. And if what person $C$ hears is not what person $A$ intended, person $C$ tells person $B$ what to adjust. And this is a process that goes on constantly, simultaneously, every moment that you are making music.

Do you have special moments, special points in the piece where you particularly focus for this kind of schizophrenic dialogue to happen? Is this in particular chords, structural points, or what kind of singular events within the piece?

No, I think it goes on all the time. There are probably, let's say, islands in the piece-from a physical point of view-where you might regroup or somehow use to refresh. No, but this process is constant, constantly ongoing. It also is a wonderful way of avoiding nerves, as you are so busy that you have no time to be nervous. Nerves are the result of self-consciousness: "Are they going to like me?" "Am I looking the way I wanted to look?" "If I make a clinker, if I make a mistake, will my career be ruined?" But if you have a goal every single moment, you don't have time for all that nonsense. Also it is very interesting, I think, in relation to the listener-if everybody is caught up in something that's happening in the music these little errors pass by partly unnoticed. But if the goal of the making of music is a kind of physical perfection, a kind of brilliance only from the physical point of view and not really with the kind of immediacy and 
urgency that comes from having musical intentions, then these little mistakes sound very important, very big. Because nothing else is going on. But if something else is going on, not to worry.

It is a commonplace to talk about "reflection" and "conceptualisation" as a part of a dualism, the other part being a combination of "intuition" and/or "tradition." When studying, practising, or performing a piece do you in some way reflect this dualism? In which part of the working process do you predominantly use reflection; and when, intuition? In the face of a concrete problem do you tend to solve it through the use of your knowledge or through intuition?

Well, while you perform, I don't think you have time to think back and wonder about this or that. These two sides are not mutually exclusive; they combine, they make no final product. I think these distinctions are not very productive. The art is the entity, it is the entirety of the whole. Certainly, it never hurts to know what you are doing. It also never hurts for your own sense of authority to know why you are doing, and I think it is best served by being able to point to this reason, to that reason, to a structural reason, whatever... And then, of course, you listen to your instinct. But if your instinct is contradicted by the composer-if you feel something to be forte and the composer writes piano-I think you try it piano until eventually the sense of what piano means in this place begins to make itself apparent.

Everybody knows Beethoven's Fifth Piano Concerto, this beautiful $\mathrm{E} b$-major chord in the orchestra followed by these waves where the piano goes up to the top. Well, it doesn't hurt to know that in this wonderful chord in the orchestra, that eighty-nine to one hundred people are playing, nobody is playing a $\mathrm{B}$ b. $\mathrm{E} b$ major, no $\mathrm{B} b$, no fifths? Everybody in the orchestra is playing $\mathrm{E} b$ or $\mathrm{G}$. And then comes the piano player [Fleisher quasi-sings simulating the arpeggios of the piano], and it gets to the top, and there it is: $\mathrm{B}$ b. Not just one but nine! [Fleisher quasi-sings simulating the trill of the piano part]. That has to have a meaning. And that gives a sense of having gotten a little bit into Beethoven's psyche. He was missing the $\mathrm{B} b$ in the chord and then there is this tsunami of waves and then this insistence. Is that a consequence of "intellectualism"? No, it's just discovering what the hell the music is about. Or when the theme comes again for the first time on the piano-at the second entrance [Fleisher sings the first four bars of this theme] — he writes “dolce." That's interesting, that's curious: something that is so maestoso, so noble ... he writes "dolce." With many young people today, the music, in terms of characterisation, is so often either heroic or revolutionary, or the other side, which is what I call "I love you." People feel that somehow they have to demonstrate how much the music affects them, how much they can pour their innards into the music. Because if they demonstrate how much they are affected by their music, maybe you will be more inclined to buy tickets to their concerts than to the other from the next studio, who might not be demonstrating how much affected he or she is by the music. 
On several occasions, after 1967, you talked about the problem of articulating in words what you till then expressed through your music making. From that moment you devoted yourself to teaching and conducting, being forced to put the music in words. To what extent did this necessity change your understanding of music?

Well, the reason that I finally had to become more precise in my thinking about music was the onset of this physical problem that I have, which is called focal dystonia. I could no longer play with my right hand. So when I wanted to change something about how the student was playing I would push him or her off the chair and say, "I think it should go this way, because of this and such and such reason." I wasn't able to do that anymore. I had to really listen and determine for myself, and be able to express in words what was different between what I thought they should do and what they were doing. That taught me in a way to listen in a much finer, more exact way.

\section{AUDIENCE QUESTIONS}

A very simple question: what brought you to playing piano? What was your first contact with the instrument?

I have an older brother and he was taking piano lessons. And he was not that interested. I remember those days - the piano teacher came to the home, the doctor also came to the home- and I just listened to his lessons. When the lesson was finished he would go to the schoolyard and play, and apparently I went to the piano and reproduced everything that the teacher had required of him. So my parents decided that they were giving piano lessons to the wrong child. That's how I started.

I would like you to talk further on the question of how to make a crescendo or a forte in Beethoven, in Chopin, in Mozart. What is a crescendo or a sforzando or where is the phrase driving in Beethoven, as opposed to Mozart, for example?

Well, one might say there are certain stylistic criteria or concerns. A crescendo in Mozart is probably not, or possibly not, as violent as ... But, you know, there are so many different instances, different kinds of crescendos ... It really depends on the context, on the material. Is it a crescendo that is like a blooming, an opening of a flower, it just increases in a kind of breadth and scope and light; or is it an aggressive crescendo? And this can happen in any composer. And what distinguishes between the composers is a question of stylistic concern. You wouldn't play as loud in Mozart as in Beethoven ... No, no ... Trying to make generalisations is very dangerous. So I prefer not to generalise. I just say that the individual contexts you have to determine by what is going on in the music. 
I once have seen a television programme (broadcasted on ARTE) where you talked about your ordeal with focal dystonia. I don't remember all the details but one question comes to my mind as you mentioned before the "inner ear." Has your ordeal with focal dystonia brought you to even more emphasis on the inner ear, consciously or unconsciously?

I don't think that emphasis on hearing in your head, hearing the music, had any influence one way or the other on my dystonia. Dystonia is a neurological movement disorder. It is in the same class as Parkinson's [disease], which is the most prevalent disorder. Then comes a category, which is "essential tremors," and a third category is "dystonia." It is comparatively recently that it has been identified. And there are two kinds of dystonia. One is genetic; it attacks the whole body and produces uncontrolled and involuntary contractions of certain muscles, people become contorted and it's very painful. The other kind of dystonia, which is my kind, is called "focal" or "task specific"; it only attacks a muscle or a group of muscles in doing a specific task, usually where it hurts-for a musician it is in the hands, for a horn player it is in the lips, and there is nothing to be done ... Glass blowers, surgeons, golfers ... And the irony of it is that it is not painful. At least if we could suffer from it there would be some sense of justification. And no one knows what causes it. There are some hypotheses, what is called "repetitive stress syndrome," but it's not sure. So there are no known causes and there is no cure for it. But some doctor figured out that they could alleviate the symptoms by the administration of a terrible poison, which is Botox-Botulinum toxin, type A. Women and men get it administered for cosmetic and pathological reasons. What it does is that the poison paralyses whatever muscle it is injected into. And in my case the fourth and fifth fingers of the right hand, which wanted to do "that" and stay that way (involuntarily and uncontrolled), if they got a very small amount of Botox, they would be paralysed and therefore not contract. It allows the opposed muscles, the extensors to be more effective. So that is what that condition is. I get those injections once every four months. There are some ten thousand musicians around the world who suffer from focal dystonia - and they don't like to let it be known, because if it gets out, their chops will be affected. So they disguise it, they get "indisposed" or "cold" or flu, or something ... I didn't do that. I got up on my legs and screamed. This is already back 1964 or 1965 . So I went through thirty, thirty-five years of not playing with my right hand-but trying everyday. It made me start teaching much more. And I started conducting. And I have had such pleasures from these activities, such satisfactions, that if I had to do the whole thing all over again I am not so sure I would change it, you know?

1 The reference is almost certainly to Leon Fleisher: Les leçons d'un maître, directed by Mark Kidel (2001). 
I have a more personal question: you mentioned today Schnabel a couple of times. Could you talk a bit about Schnabel and your work with him?

Oh, this could go on and on for a long time ... Besides being, historically, one of the most important figures of the twentieth century... I think that the nineteenth century was filled with bad habits-that's when performers began to emerge as being differentiated from composers/performers, and this whole idea of playing for the public rather than just for the court, or the duke, or the count, or the archbishop. In order to have success they began changing the composer's intention because that was thought to be more successful for the public. And then came Schnabel and another musician from a different angle but with the same motivation: that was Toscanini. I think between Schnabel and Toscanini they brought back the integrity of the composer. It's a very interesting relationship: it's a triadic relationship between composer, performer, and listener. The performer is indispensable, because without the performer the music simply remains black dots on a piece of paper. It needs to be brought to life by a performer. But the performer is not the centre of attention-the music is the centre of attention. There is a very fine line to walk: to be indispensable and yet to be only the vessel from the composer to the listener.

Schnabel was the most inspired and inspiring person I have ever met in my life, which doesn't say much particularly. The level of his music making constantly took you out of yourself, and you lived on another level of human awareness. One thing that I followed him in doing was his way of teaching. He had only a small handful of students at a time, but he invited all to be present at everybody else's lessons, which was of enormous benefit, as if we were four students at a time, we would hear four times the repertoire. We would all share the challenges and we would have an overview of music that was invaluablewhether it was Spanish, Russian, or German music, there are almost physical laws of music. Laws are, of course, meant to be broken (because they are manmade), but if you are going to break the law you have to realise that it is a law, why it's a law, and why you are breaking it. And all of this began to make a pool of thought, a pool of feeling, a reservoir that was irreplaceable and almost indescribable. Ten years I worked with him, from the age of nine to nineteen. It is almost as if he had two different lives: when he taught in Berlin, back in the 1920 and 1930s, his students were not always positive, they said he could be sarcastic, and I think he damaged, psychologically, some of his pupils, who then taught in the same manner; but when I met him he already had moved to Italy. I couldn't imagine that crossing that border would make that huge difference, but he was like a Santa Claus. He was smiling; his English, his command of English, was remarkable. He spoke a bit like Richard Burton with a German accent, a slow speech where every syllable was caressed and massaged. He was never abusive, but he demanded a lot and he could become impatient when you were slow in responding. He was a remarkable person. 


\section{An Interview with Leon Fleisher}

\section{REFERENCES}

Brendel, Alfred. 2001. "Notes on a Complete Recording of Beethoven's Piano Works." In Alfred Brendel on Music: Collected Essays, 16-29. Chicago: A Capella Books. Essay first published in German as "Anmerkungen zu einer Gesamtaufnahme der Klavierwerke Beethovens" (Hi Fi Stereophonie, May 1966).
Fleisher, Leon, and Randy Stewart. 2004. "Arts News Leon Fleisher Interview." KSMU-Ozarks Public Radio. Accessed 12 August 2015. http://ksmu.org/post/artsnews-leon-fleisher-interview\#stream/o. Kidel, Mark, dir. 2001. Leon Fleisher: Les leçons d'un maitre. Paris: ARTE / Les Films d'ici. First broadcast 30 January 2002. 


\title{
Execution Interpretation Performance
}

\section{The History of a Terminological Conflict ${ }^{*}$}

\author{
Hermann Danuser \\ Humboldt University, Berlin
}

Let us introduce our subject by depicting two situations to show that the question of what constitutes music cannot be answered by resorting to definitions. The first took place in the summer of 1888 in the Swiss city of Berne; the second, a century later, let us say, or perhaps in our own day.

One morning we enter a garden in Berne and find a man with an impressive beard lost in thought. As we approach him and try to engage him in conversation, he starts out of his reverie and then calls himself "the best of all Wagnerians" (note: not "the greatest," but "the best"). Did this "Wagnerian" just arrive from Bayreuth, filled with memories of a formative artistic experience? Not in the least; he has never been to Bayreuth. Yet he insists, swelling with pride, that his "understanding of Wagner's scores is probably more profound than that of any other man alive." Who was this "best of all Wagnerians"? In fact, it was Johannes Brahms. The scene was handed down by his Bernese friend Joseph Viktor Widmann ([1898] 1980, 82). It tells us that music exists not

\footnotetext{
DOI http://dx.doi.org/10.11116/9789461661883.cho9

This paper is the result of a kind invitation from Saggiatore musicale to take part in their colloquium "L'esecuzione tradotta in parole" on 24 November 2007 (Dipartimento di Musica e Spettacolo, Università di Bologna). Since then I have delivered the paper twice, once at the colloquium of the European Network for Musicological Research (ENMR) in London on 3-4 April 2008 ("The Study of Music as Performance") and again at the Basle Hochschule für Musik on 17 February 2009. I have revised it for publication (see Danuser 2014) and enlarged its first section, but otherwise I retain the style of an oral presentation. Everything stated here is open to revision, particularly with regard to the forthcoming results of a joint research project by Jacob Langeloh, Laure Spaltenstein, and Vera Emter-Krofta at Humboldt University, Berlin: “From 'Execution' to 'Performance': A Conceptual History of Musical Performance Since the 18th Century" ("Von 'Exekution' zu 'Performanz'. Eine Begriffsgeschichte musikalischer Aufführung seit dem 18. Jahrhundert”). I am deeply grateful to J. Bradford Robinson for his excellent English translation. Unless otherwise stated, all translations are by Robinson.
} 
only in actual sound, but lives in the process of imagining that sound. "Music for reading"-Musik zum Lesen, to quote the subtitle of Dieter Schnebel's book, a European parallel to John Cage's Notations (both appeared in 1969)-is not limited to the culture of the avant-garde. On the contrary, for musicians versed in the history of musical notation, it specifies a possible foundation for their art. Music runs in the mind of the listener; the real world remains silent.

This scene demonstrates that music can exist where nothing is heard at all. Conversely, ever since the invention of the technological reproduction of noises, sounds, and hence music, there has existed a situation in which music can be brought into being without human agency. Can we picture the amazement musicians of an earlier age would have felt if they had heard music or works emitted in a room or out of doors by a machine-whether loudspeakers, earpieces, computers, or iPods-without a human to produce the sounds? Presumably not. But this second situation, whether eerie or normal, has helped to define the first, our view of music. It has altered our listening culture no less than our musical practice.

If the two situations briefly outlined above demonstrate that there can be music without sound or, respectively, without human activity, we should take it as a warning not to resort to short-sighted theses that patently stand in need of revision the moment we pause to think about them. My subject is related to two scholarly approaches common to Italy and Germany alike: terminological history, which, following the end of the Handwörterbuch der musikalischen Terminologie (HmT), is now being carried on by Gianmario Borio and Carlo Gentili in their research project Storia dei concetti musicali, ${ }^{1}$ and reception history, which kindles memories of the Bologna congress of the International Musicological Society in 1987, headed by Lorenzo Bianconi (Pompilio et al. 1990; see Kropfinger 1994-2007). For the purposes of our discussion, I will simply repeat a dictum often quoted by Hans Robert Jauss: "Quidquid recipitur ad modum recipientis recipitur" (Jauss 1991, 17-18; Whatever is received into something is received according to the condition of the receiver [and, we might add, not the condition of the author]). What does this dictum mean for our discussion?

Our musical experiences, our auditory faculties, even the language in which we communicate about things we have heard: all are dependent on terminological constellations without which communication and knowledge would be culturally impossible. The three concepts in the title of my paper-execution, interpretation, performance-though seemingly related to one and the same phenomenon in our discourse (namely, the acoustical presentation of music), mean quite different things and have highly contrasting historical scopes, depths, and traditions. It is my contention that our judgements and language are governed by different yardsticks depending on the culture to which the acoustical presentation of a work is related. Moreover, as the reference to Jauss makes clear, our decision regarding this culture is made not (or at least not entirely) by the authors of the work presented but, quite decisively, by listen-

1 To date three volumes have appeared in print (Borio and Gentili 2007a, 2007b; Borio 2009). 
ers, critics, audiences, and scholars. We shall see that an acoustical presentation that we consider well executed may be unsatisfactory as an "interpretation" of the work, and that, conversely, a respected "interpretation" of a work may be too intricate, complex, or recherché to be judged by the yardstick of "execution." Similar disproportions recur with the third of our three concepts, performance.

In German, these concepts reflect not only different epochs (Exekution has existed since the eighteenth century, Interpretation since the nineteenth, and Performance since the latter half of the twentieth) but different etymologies and source cultures. The fact that they coexist today has given rise to a conflict, provided that we emphasise their conceptual differences over the meanings they have in common. We will now discuss these terms in three stages. First, we shall examine "execution" in the sense of Auffihrung - that is, the acoustical presentation of a work of music before an audience (a term not at all synonymous with musical practice) - and in the sense of Ausführung - the acoustical realisation of a musical text, drawing on some quotations from historical sources in order to stake out an area in the history of terminology. Then we shall turn to "interpretation," a foreign term that found its way into German long ago as Interpretation, the "artistic rendition of music, where 'artistic' is based on a subjective viewpoint" (Drosdowski 1977, 3:1356). Finally we shall look at "performance," an English word originally synonymous with execution or interpretation that has only recently entered German with a different meaning.

Research into terminological history, including comparisons among the principal European languages, is still largely wanting and urgently needed. None of the terms in the title of my paper is dealt with in $\mathrm{HmT}{ }^{2}$ True, they are not "musical" terms pure and simple, but concepts with many applications outside music itself. Still, their absence reveals a neglect of music's sonic form of existence in aesthetic, psychological, institutional, and social frames of reference. The words I have chosen to outline here by no means cover the entire semiotic field of their subject since the eighteenth century, for I have excluded other key concepts from my paper- "recitation" (Vortrag), "reproduction" (Reproduktion), "presentation” (Darstellung), “expression” (Ausdruck), “rendition” (Wiedergabe), "re-creation" (Nachschaffen)—whose relations among one another, and to my three terms in particular, stand in need of clarification. Moreover, as with historical terminological research in general, a distinction must be made between the emergence of a thing (regardless of its linguistic paraphrase), the origin and dissemination of words in various sources (especially reviews, letters, and textbooks), and the presentation of technical terms (in dictionaries and encyclopaedias). 3 The thoughts below thus make no claim to comprehensive coverage

2 Not one of them appears in J. G. Sulzer's late eighteenth-century lexicon Allgemeine Theorie der Schönen Künste $(1771 / 74)$. Nor are the two terms that entered German from other languages (Interpretation and Performance) dealt with in J. Grimm and W. Grimm's Deutsches Wörterbuch (1854-1960), because their choice of words focused, at least initially, on terms that originated in German. The terms Auffuihrung and Ausführung and their associated verbal forms are included, but with no bearing on music.

3 See, among other things, Danuser (1992b); Riethmüller (1998); Hinrichsen (1999); Ballstaedt and Hinrichsen (2008); Bockmaier (2009). 
of this extremely broad and varied conceptual field. Rather, they are intended to provoke such an investigation, which may well prove important to the future of musicology and to set it in motion.

EXECUTION (EXEKUTION-AUFFÜHRUNG/AUSFÜHRUNG)

By no means do these terms stand at the head of terminological efforts to give a name to the making of music. Other coinages were in circulation for centuries, such as cantare (Latin and Italian for "to sing"), spielen (to play), or words denoting the playing of specific instruments. One prerequisite for the concept of "execution" arose with the awareness that turning music into sound on the basis of musical notation is something different from improvising according to rules (as in Tinctoris's contrast between res facta and cantare super librum [see Bent 1983]). It is not music that can be executed, but only works of music. ${ }^{4}$ Works can and must be realised, made to resound, transformed from the stage of conception or notation into something audible, into structural sonic processes capable of being perceived.

Johann Gottfried Walther, writing in 1732 at a time when French culture was predominant, used the term Auffiihrung to explain the words executio or exécution: "Executio (Lat.), Execution (Fr.): the rendition [Auffuihrung] of a piece of music" (Walther [1732] 1953, 233). In substance, this concept circulated with a relatively modest vocabulary in the course of the eighteenth century as musical practice gradually became a subject of Enlightenment critique, especially in France, England, and the German-speaking countries. As music found its way into public concerts and music criticism arose with news value, writers were forced to develop a language with which they could convey an impression of a concert to their readers. Initially this information was rudimentary, but it was a beginning that could and did grow. Basically, what was involved were contemporary pieces, not historical works or texts from the past. As a result, this "home-grown" approach could remain valid for a fairly long period of time; even in the case of modern music performed for the first time or still at the onset of its reception history, performance resided by and large in execution.

By the late eighteenth century, the two terms Auffiihrung and Ausführung were still not firmly rooted in general linguistic usage, no matter how often they cropped up in textbooks. This is evident because neither has an entry in Sulzer's Allgemeine Theorie der Schönen Künste, where the field is covered in an article by Johann Abraham Peter Schulz on musical recitation: Vortrag (Musik) (Sulzer $1771 / 74,2: 1247^{-5} 5^{8}$. Indeed, these terms, which partly overlap, both compete with and complement each other in the work of lexicographers.

4 A contrary opinion is held by adherents of the Georgiades school in Munich and the theatre studies department in Berlin. Both posit the concept of execution or Auffuihrung in a very general sense, the former including non-literate musical practices of extra-European cultures, the latter equating it with the English term "performance." See Göllner (1980); Brüstle and Risi (2008). In my view, however, this general application of the term is contrary to German usage. 
The concept of recitation (Vortrag) in literature and music is dominated by an ambiguity rooted in the nature of the subject and its historical gestation (see Sulzer's Allgemeine Theorie). This same ambiguity comes into play in a different form with the term Ausfürung in Heinrich Christoph Koch's Musikalisches Lexikon, which adopts the term both for the poetics of composition and for the practical performance of music, dividing it into three steps: Anlage (design), Ausführung (execution), and Ausarbeitung (elaboration):

Ausfuihrung... This is not the case with the works of the composer, whose finished score, without the aid of a recitation [Vortrag], consists of nothing so much as a script of hieroglyphs intelligible only to the minds of those initiated into the sanctum sanctorum of his art. Such a finished work of art is dead to ordinary and general enjoyment and must first be translated through the ear to the sensory faculties by a living presentation of its signs using vocal organs or instruments. Thus it transpires that the word Ausführung has two different meanings in music. It is used (1) to indicate a certain part of the manner in which a piece is carried out; one says, for example, that this or that piece of music has been well-executed [ $g u t$ ausgeführt] by its composer. In this case, we are thus speaking of the manner in which the composer has carried out the main ideas of the compositional fabric in its various periods. But the same word is used (2) when speaking either of the recitation [Vortrag] of a particular voice or instrumental part, or a joint recitation of all parts in the piece. We are therefore accustomed to say that [a musician] has taken over the execution [Ausführung] of this or that part, or that the piece was well-executed by the orchestra. (Koch [1802] 1985a, 187-88) 5

Later the article expands on the idea of "recitation" inherent in Ausführung, clearly drawing on elements from linguistic rhetoric:

The execution [Ausfiihrung] of each part requires that its contents be brought out note for note lightly and well, with pure and distinct intonation, with no blurring of the notes, and with utmost firmness of rhythm. When this mechanical skill is applied in such a manner that it fully corresponds to the character of the piece and the intentions of its composer, it is called a good recitation [guter Vortrag]....

... Good execution [gute Ausführung] depends on many coincident circumstances and nuances, all of which contribute sometimes more, sometimes less, to the perfection of the whole, and all of which must necessarily be observed if a piece of music is to be well-executed. Besides the aforementioned characteristics demanded of everyone who wishes to play one or another part in the execution of pieces, good

5 "Ausführung.... Nicht so bey den Werken des Tonsetzers, dessen vollendete Partitur ohne Beyhülfe des Vortrags gleichsam nur noch eine Schrift von Hieroglyphen enthält, die nur dem Geiste des Eingeweiheten in dem innersten Heiligthume der Kunst verständlich ist. Für den gewöhnlichen und allgemeinen Genuß ist ein solches vollendetes Kunstwerk noch tod, und muß erst durch lebendige Darstellung seiner Zeichen vermittelst der Gesangorgane oder der Instrumente dem Empfindungsvermögen durchs Ohr verdollmetschet werden. Daher kömmt es, daß das Wort Ausfïhrung in der Tonkunst zwey verschiedene Bedeutungen hat, denn (1) bedient man sich desselben, um einen gewissen Theil der Bearbeitungsart der Tonstïcke damit zu bezeichnen; man sagt z. B. der Tonsetzer habe dieses oder jenes Tonstück gut ausgeführt. In diesem Falle ist also die Rede von der Art, wie der Componist die Hauptgedanken des Satzes in den verschiedenen Perioden desselben durchgeführet hat. Man braucht dieses Wort aber auch, (2) wenn entweder von dem Vortrage einer besondern Stimme, oder von dem gemeinschaftlichen Vortrage aller zu einem Tonstücke gehörigen Stimmen die Rede ist; daher pflegt man zu sagen, er hat die Ausführung dieser oder jener Stimme übernommen, oder das Tonstück ist von dem Orchester gut ausgeführet worden, u.s.w." 


\section{Hermann Danuser}

execution also depends on the following items: (1) the disposition of parts in a piece, (2) the proportionate number of musicians per part, (3) the pure tuning of the instruments, (4) the leadership of the conductor, and (5) the observation of all those duties for which each performer [Ausfuhrer] is responsible in the joint execution of a piece of music. (Ibid., 192-93) ${ }^{6}$

Evidently lexicographers faced a dilemma: either they had to exclude terms in order to convey the semblance of a clearly ordered terminological domain, or they had to include several partly synonymous terms and delimit them, often arbitrarily, to lend them a distinctive profile. The problem is manifest in the entry on Vortrag, which Koch defined more narrowly than Ausfuihrung:

Vortrag: At first glance the words Vortrag and Ausführung seem identical, because we are accustomed to substitute one for the other often in conversation. Yet when one speaks of the good execution [Ausfuihrung] of a piece of music, one usually thinks not merely of the good joint recitation [Vortrag] of all parts belonging to the piece but also, at the same time, the pure tuning of the instruments, a good disposition and proportioning of the musicians, and so forth. From this we can see that we actually associate with the word Vortrag a more limited meaning than with the word Ausfürung and that by Vortrag we mean nothing more than the application of those skills that make each part in a work of art perceptible to our ears. (Koch [1802] 1985b, $1729-30)^{7}$

This dual meaning of Ausführung was retained in the corresponding entry in Gustav Schilling's Encyclopädie, except that the relation between Ausführung and Vortrag was reversed. Now it is Ausführung that receives the narrower definition:

In the second meaning of the word, Ausführung must be distinguished from Vortrag. The former relates to the latter as a part to the whole. Vortrag, the recitation of music, is what we call declamation in oral speech. Ausführung, in contrast, can only be compared to common talking or reading, where it suffices that the syllables and

6 "Die Ausführung jeder einzelnen Stimme erfordert, daß ihr Inhalt Note vor Note mit reiner und deutlicher Intonation, ohne Verwischung der Töne, mit der strengsten Taktfestigkeit, leicht und rund herausgebracht werde. Wird diese mechanische Fertigkeit so angewendet, daß sie dem Charakter des Tonstücks, und der Absicht des Tonsetzers vollkommen entspricht, so nennet man sie insbesondere guten Vortrag....

“... Die gute Ausführung hängt von vielen zusammentreffenden Umständen, von vielen Nuancen ab, die alle bald mehr, bald weniger zur Vervollkommung des Ganzen beytragen, und die nothwendig alle beobachtet werden müssen, wenn eine gute Ausführung der Tonstücke statt finden soll. Nächst den schon vorhin angezeigten Eigenschaften, die von jedem, der bey der Ausführung der Tonstücke diese oder jene Stimme vortragen will, gefordert werden müssen, hängt die gute Ausführung noch von folgenden Stücken ab: (1) von der Stellung der zu einem Tonstücke gehörigen Stimmen; (2) von der proportionirlichen Besetzung der Stimmen; (3) von der reinen Einstimmung der Instrumente; (4) von der Direktion des Anführers, und (5) von der Beobachtung aller derjenigen Pflichten, welche jedem Ausführer insbesondere bey der gemeinschaftlichen Ausführung eines Tonstückes obliegen.”

7 "Vortrag. Dem ersten Ansehen nach scheinen die Wörter Vortrag und Ausführung identisch zu seyn, weil man gewohnt ist, sie im Gespräche einander oft zu substituiren. Allein wenn man von der guten Ausführung eines Tonstückes spricht, so pflegt man darunter nicht bloß den gemeinschaftlichen guten Vortrag aller zum Tonstücke gehörigen Stimmen, sondern auch zugleich die reine Einstimmung der Instrumente, eine gute Stellung und verhältnißmäßige Besetzung der Stimmen u.s.w. zu verstehen. Hieraus siehet man, daß man eigentlich mit dem Worte Vortrag einen eingeschränktern Sinn, als mit dem Worte Ausführung, verbindet, und unter dem Vortrage bloß die Anwendung derjenigen Kunstfertigkeiten verstehet, wodurch jede einzelne Stimme des Kunstwerkes für unser Ohr empfänglich gemacht wird." 
words be clearly enunciated but little or no attention is given to the actual sense of the discourse. We therefore speak of the Ausführung of movements, passages, figures, and parts, as well as entire pieces, and of several parts belonging to a piece of music. A piece may be executed properly without being recited well or with the requisite expression, but not vice versa. Accordingly, this type of Ausführung is actually nothing more than the exercise of a purely mechanical skill for truly bringing out every note to be heard in the recitation of a piece... with the purest and clearest possible intonation, without blurring into another note, with utmost precision of rhythm, [and] with lightness and roundness. The accentuation of the notes does not come into consideration, this being the preserve of Vortrag. (Schilling [1835-42] 2004, $1: 341)^{8}$

Not only does Schilling's Encyclopädie distinguish between Ausführung and Vortrag, it also has a separate entry on Auffihrung (performance):

The Auffuihrung of a piece of music means making the piece perceptible or sensible, i.e. the presentation of a musical creation so that it can be perceived in all its parts by the auditory faculty. The recitation [Vortrag] of smaller pieces is not commonly referred to as Auffuhrung, although there is basically little difference between the two expressions; rather, the latter is used only in connection with works of a larger scale or of a composite nature, such as oratorios, operas, symphonies, large choruses, and similar items. The terms executieren or vortragen are preferred in connection with the other, smaller pieces.... Thus, one says that overtures, concertos, quartets, and so forth are executed [executieren, ausführen], whereas sonatas, rondos, and so forth are recited [vortragen] or, less often, performed [auffüren]. (Ibid., 1:319) ${ }^{9}$

As part of this definition, three agents are given leadership roles in an Aufführung: the Capellmeister (conductor or musical director), the Orchesterdirector (concertmaster), and, in the case of oratorios, the Chordirector (choir conductor) (ibid., 1:321-22).

This is not the place to retrace the history of these terms in detail from their appearance in dictionaries. Just how variably the field could be marked out is revealed by a glance at the third edition of Hugo Riemann's Musik-Lexikon (1887),

8 "In der zweiten Bedeutung des Worts muß Ausführung wohl von Vortrag unterschieden werden. Jene verhält sich zu diesem wie ein Theil zum Ganzen. Der musikalische Vortrag ist das, was man bei der mündlichen Rede Declamation nennt; die A. hingegen ist nur mit dem gewöhnlichen Hersagen oder Lesen zu vergleichen, das sich mit der deutlichen Aussprache der einzelnen Sylben und Wörter begnügt, auf den Ausdruck des eigentlichen Sinnes der Rede aber wenig oder gar nicht achtet. Daher spricht man von der A. einzelner Sätze, Passagen, Notenfiguren und Stimmen, so wie ganzer Tonstücke, und mehrerer zu einem Tonstücke gehöriger Stimmen, und kann man ein Tonstück richtig ausführen, ohne es gut oder mit dem erforderlichen Ausdrucke vorzutragen; aber nicht umgekehrt. Demnach ist diese Art der A. eigentlich nichts anderes als das Werk rein mechanischer Fertigkeit, daß jeder Ton, der bei dem Vortrage eines Tonstücks gehört werden soll ... wirklich auch mit möglichst reiner und deutlicher Intonation, ohne ihn mit einem anderen zu vermischen, mit der strengsten Taktfestigkeit, Leichtigkeit und Rundung hervorgebracht wird. Die Accentuation der Töne kommt dabei noch nicht in Betracht, diese ist Sache des Vortrags."

9 "Aufführung eines Tonstücks ist die Sinnlichmachung oder Versinnlichung desselben, d. h. diejenige Darstellung einer musikalischen Dichtung, wodurch dieselbe nun auch in allen ihren Theilen mit dem Gehöre wahrgenommen werden kann. Den Vortrag kleinerer Tonstücke pflegt man gemeiniglich noch nicht Aufführung zu nennen, obschon im Wesentlichen wenig Unterschied unter beiden Ausdrücken ist, vielmehr gebraucht man den letzteren nur von Tondichtungen größerer und combinirterer Art, z. B. von Oratorien, Opern, auch Sinfonien, größeren Chören u. dgl.; bei den übrigen, kleineren, bedient man sich lieber des Ausdrucks 'executiren' oder 'vortragen', so sagt man: eine Ouvertüre, ein Concert, Quartett etc. executiren oder ausführen, eine Sonate, ein Rondo etc. vortragen, weniger aber aufführen." 
which lacks entries on Aufführung, Ausführung, Exekution, and Interpretation altogether. The entry on Vortrag refers the reader to Ausdruck (expression), to which Riemann apparently assigns key significance for the entire terminological field. Only Vortragsbezeichnungen (expression marks) is accorded an entry of its own (Riemann 1887, 1063-64).

In the twentieth century, when research into historical sources witnessed a great upsurge, progressive musicologists lumped Aufführung, Ausführung, and Vortrag as related to earlier music under the heading of Auffuihrungspraxis (performance practice). To the present day this term has served as a portmanteau word for historically informed approaches to the acoustical realisation of works of music, or of music altogether. To take an example, the conceptual section of the Riemann Musiklexikon (Eggebrecht 1967b) is no different from its eightyyear-old predecessor in lacking entries on Aufführung, Ausführung, Exekution, and Vortrag, but it provides articles on Aufführungspraxis (Dahlhaus 1967) and Interpretation (Eggebrecht 1967a). Auffuihrungspraxis, and with it the concept of Ausführung, is defined as "in general the totality of techniques, rules, and habits that mediate between a musical text and the sounding result; specifically the 'performance practice of early music,' meaning the reconstruction of historical modes of performance in today's practice" (Dahlhaus 1967, 59). ${ }^{10}$

This definition of Auffihrungspraxis, or any earlier or later one for that matter, lends expression to a fact that has grown constantly in significance since the nineteenth century: namely, that the music to be "executed" is a text from the past, a text whose meaning is not immediately apparent and realisable, with the result that, as in all historical research, conflicting modes of interpretation, contrasting performance styles, and other differences in dealing with texts have given rise to a broad and multifarious range of practices.

Ausführung-execution-seems compelling especially when the notation in question has unusual traits, as is often the case in many avant-garde works of the twentieth and twenty-first centuries. The difficulty of presenting works by, say, Karlheinz Stockhausen or Helmut Lachenmann clearly reveals the enormous importance of "execution" for the acoustical realisation of such music. These composers have painstakingly drilled willing performers-singers, instrumentalists, conductors-in the way they want their music performed in order to establish an authorial tradition during their lifetimes. ${ }^{11}$ Divorced from the era of their composition, the "execution" of works written in musical notation becomes, with the assistance of musicology, the task of Auffuihrungspraxis. As in Dahlhaus's thumbnail definition, this term is so closely associated with

10 "generell der Inbegriff der Techniken, Regeln und Gewohnheiten, die zwischen Notentext und erklingender Musik vermitteln, speziell als 'Aufführungspraxis alter Musik' die Rekonstruktion geschichtlicher Ausführungsweisen in der heutigen Praxis.” See also Gutknecht (1994-2007, esp. 954-69); Reidemeister (1988).

11 In February 2009 the Zurich-based pianist, producer, and musicographer Christoph Keller, who for decades has frequently performed contemporary music, told me in conversation that, to his way of thinking, only the term Ausfuihrung (execution) and not Interpretation is applicable to contemporary music. During the lecture of this paper, however, the musical example chosen for Ausführung-Helmut Lachenmann's string quartet Gran Torso $\left(1971^{-72 / 78)}\right.$ in a new recording by the Arditti Quartet (2007), an extraordinarily rich and convincing rendition-made abundantly clear that this work has already entered the stage of "interpretation history." 
early music, however we may choose to delimit it, that its application to contemporary music, though urgently needed, may well seem problematic. Still, as "early music," "contemporary music," and Aufführungspraxis are independent concepts, each with its own history, any lines of demarcation we draw for the purpose of their definition will have an inherent tendency to blur. All early music was contemporary music before being subjected to the process of ageing.

In sum, Auffuihrung (performance) and Ausfuihrung (execution) have managed to retain their relevance to the present day, even if they elude the lexicographer's grasp (the new edition of Die Musik in Geschichte und Gegenwart, published under the aegis of Ludwig Finscher at the end of the millennium, contains, in sweet accord, entries on Auffuihrungspraxis [Gutknecht 1994-2007], Interpretation [Danuser 1994-2007a], and Vortrag [Danuser 1994-2007b]). Yet a difference between the old and new Handbuch der Musikwissenschaft reveals a shift of emphasis from Auffuihrungspraxis to Interpretation: the original Handbuch, edited by Ernst Bücken in the first half of the twentieth century, contains a volume by Robert Haas on Auffuihrungspraxis der Musik (Haas 1931), whereas the new Handbuch, edited by Carl Dahlhaus in the latter half of the century, features a volume on Musikalische Interpretation (Danuser 1992b). ${ }^{12}$

\section{INTERPRETATION}

This term, which is used by scholars to mean not only "hermeneutic exegesis" but also, and especially, "presentation in sound," opens up completely different perspectives compared with "execution" or even "performance." Here is the definition offered by Hans Heinrich Eggebrecht (1967a, 408):

Interpretation, the sonic realisation of a piece of music by an instrumentalist, singer, or conductor, means not only the explication (Lat. interpretatio) of a vehicle of meaning, but also the translation or recasting of a written vehicle into a sonic vehicle. On the level of understanding or comprehension, the quality, subjectivity, and history of interpretation all come into play in the gap between musical notation, which reckons with and depends on this act of translation, and its sonic reproduction.

To be meaningful, "interpretation" presupposes that the text of a work of music is something not comprehended in itself and that therefore it stands in need of explication. A simple, casual, and spontaneous type of sonic realisation, as envisaged by Exekution, Ausführung, or Auffïhrung around the year 180o, can no longer be assumed. On the contrary: owing to the separation between composer and performer, the text of a work can be both temporally and geographically remote; it has lost its appearance of something self-evident-an appearance which may be deceptive but which nonetheless existed-and stands in

12 I recall a conversation with the series editor, Carl Dahlhaus, in the course of which I asked him whether the projected volume in the Neues Handbuch der Musikwissenschaft should have the term "Aufführungspraxis" or "Interpretation" in the title. He clearly answered in favour of the latter. The volume Musikalische Interpretation, one of two additional volumes Dahlhaus had planned (the other was Populäre Musik,), only appeared after his death, when it was published in 1992. 
need of explication as if it were a string of hieroglyphs. Only when the "understanding" of music has become a problem can "interpretation" occur, as it has since the mid-nineteenth century (see Zaminer 1973). ${ }^{13}$

This involves a shift of emphases in the constitution of works of music and music theatre. The question arises how, as in works with multiple authors, the relative proportions are publicly projected. As late as 1900 the conductors in charge of opera performances in theatres and opera houses were not, as is well known, mentioned on theatre playbills; we need other sources in order to discover whether, for instance, Gustav Mahler did or did not conduct at the Vienna Court Opera on a particular evening. Works performed in the early nineteenth century fell under the focus of musical journalism and were described at length, whereas often all that was said of the performance was that it was "appropriate" to the work in question (whatever that might mean in particular). Today, in contrast, one can wander through Berlin and find posters on which the names of the performers appear in huge print (Daniel Barenboim, Lang Lang) and the name of the ensemble in only marginally smaller type (Berlin Staatskapelle), whereas the names of the composers, much less the titles of the works, are given in very small type and thus, by the standards of a poster, virtually left unmentioned ${ }^{14}$-a glaring but nonetheless typical case. Accordingly, the conductor who conducts a piece at its premiere often receives a higher fee than the composer who provided the musical text. The Austrian composer Olga Neuwirth recently kindled a polemical debate by calling for a terminological hierarchy beginning with "first creator" (Erstschaffender, i.e., the composer), descending to "reproducer" (Nachschaffender, i.e., the performer), ${ }^{15}$ and finally landing, if at all, at the side table of musicology, where the concept of creativity is skirted altogether and seemingly replaced with parasitism. Yet not even such polemical diatribes can change the cultural divide or cause the public to switch allegiances. The trend that Hugo Riemann (1895, esp. 8) ruefully noted at the end of the nineteenth century-that one hundred years earlier the composer and author of a work of music was the focus of attention, whereas now it is the performer of that same work-has thus proceeded apace and considerably intensified. ${ }^{16}$

13 Here I exclude my heuristic distinction between three modes of interpretation: "traditional," "historical-reconstructive," and “modernising” (see Danuser 1992a, 13-17).

14 As happened in summer 2007 for concerts at the Berlin Waldbühne.

15 In her talk "Hinter den Spiegeln," delivered at a Salzburg Festival symposium devoted to the subject of "Festivals from the artist's vantage point: visions, desires, reality" Olga Neuwirth $(2006,38)$ expressed herself as follows: "I continue to insist on the distinction between erstschaffende and nachschaffende artists. The latter, the performers, are thought to produce something measurable, whereas the former, the composers, are not. Yet composing is a deeply craftsmanlike activity, with the disadvantage that many people cannot fathom it and therefore regard it as valueless or at least purposeless. Performers are considered an economic factor in their almost athletic measurability. This is apparent in the exorbitant differences in the fees they receive compared to composers."

16 In a letter of 5 February 1884 , Hans von Bülow wrote to Hermann Wolff that "Brahms's mission is 'pro-duction' whereas mine is 'repro-duction,' and thus two extra letters. Sufficient for the wildest ambitions!” (quoted in Hinrichsen 1999, 228; Brahms' Mission ist zu pro-, meine zu repro-duziren, also zwei Buchstaben mehr. Genügend für die wildeste Ambition!). This does not apply to the same extent to the culture of contemporary music, where the presence of such authors as Lachenmann and Rihm is more important than that of their performers, whom they instruct in courses. 


\section{Execution-Interpretation-Performance}

Relevant areas of music research and criticism-such as the comparison of interpretations (which raises methodological problems of its own), the theory of interpretation (recently made the object of attention with the appearance of Adorno's fragmentary Theorie der musikalischen Reproduktion [2001]), and the revolution brought about in music's technological prerequisites by research into new media (they increasingly confer museum status on the very art that, until the late nineteenth century, was associated with what Adam von Fulda ([1490] $1963,335)$ called meditatio mortis owing to the transience of its physical basis, the decaying sound) - all form part of the potential that today's "interpretation culture" holds in store as a task for scholarship.

One set of problems lurking in "interpretation" is the ambiguity of the concept itself. Is it methodologically viable in the above sense only when we use it solely as a label for the sonic presentation of works of music and view its proximity to musical hermeneutics with critical detachment? Two decades ago, when I edited volume 11 of the Neues Handbuch (Danuser 1992b), I decided to exclude hermeneutics from the area under discussion and to focus squarely on performance practice. I wanted to prevent "interpretation" from giving rise to a ponderousness of the sort that the Hamburg musicologist Constantin Floros descried in "contents"-a concept requiring semiotic decryption-and described with problematical methodology in many books. But the moment one attempts to grasp interpretation as a cultural fact, hermeneutics and performance practice can hardly be kept meaningfully separate (see Kraus 2008; Hinrichsen 2008).

Moreover, to address another problem for scholars, in the case of "interpretation" we must distinguish between an imaginary "conception of a work's performance" and its audible "realisation"-a distinction proposed by Edward T. Cone in his essay "The Authority of Music Criticism" (1981). The performer, Cone argues, does not realise the text of a work but rather the interpretative conception that she or he formed from that text. What we hear, criticise, and study must therefore be evaluated against this dual backdrop. Further, it is equally clear that "interpretation" is based on texts and leads to texts: first, on the composer's musical text and books on musical performance (which admittedly struggle with the question of whether the most important part of music lies in the text at all); and second, assuming that the work has been recorded, on the sonic text of a work, which merits scholarly investigation. ${ }^{17}$

Two examples involving the absence of visible music-making may serve to illustrate the difference between "interpretation" and "performance." The first comes from my years of study in Zurich. In winter 1969 the Conservatory introduced a rule for a competition (the Landolt Piano Competition), according to which the musicians who entered the lists had to play behind a curtain. In other words, the jury did not know who was playing at any given time; its members sat in the auditorium and listened to the works played without being able to see the actions of the player. Is this nonvisual mode of interpretation widespread,

17 See Gottschewski’s (1996) groundbreaking dissertation. 
or is it related to Zurich's genius loci: its Protestant legacy and aversion to visual imagery?

The second example is more familiar. After many years spent as a concert pianist Glenn Gould, unquestionably a great artist, withdrew into the recording studio, which offered him two advantages. The first coincides with the aspect mentioned above: the visual side of musical performance could be safely ignored; the artist was able to concentrate on the audible without being placed on view. The second reveals interpretation to be an act of "com-position," by which I mean "putting together" in the literal sense. Just as an actual composer-Beethoven, say-never rested until he had assembled the notated text of a work from his countless sketches and drafts, the sound-composer Gould never rested until he had recorded the audible "interpretation" of such a work in the sonic form corresponding to his "conception," which was highly active, supremely demanding, and present only to him. The magic of "live performance" had lost all its charm. Like an athlete in constant training, Gould aimed to achieve a result that was com-posed ("put together") but would still project undiminished conviction as a sonic work of art. Gould was one of the greatest musicians of the past century, and to view him merely as a Zweitschaffender-a "reproducer"-is to betray a presumption born of ignorance.

At this point I should like to insert a story that Carl Dahlhaus told me with an impish grin around the year 1980. Twenty years earlier, when he was an editor of the Stuttgarter Zeitung, he developed an infallible way to counter complaints from musicians about critical reviews of their concerts. He summarily gave the complainers a choice: either they could have praise of their "performance" published in the local section of the newspaper, or they could have a critique of their "interpretation" on the arts page. None of the complainers, he said, decided in favour of the local section, where praise would have been possible. All chose the arts page, which included critique of interpretation. Dahlhaus did not use the two terms directly, but I think it permissible to interpolate them for what he meant. ${ }^{18}$

The opposition of these two concepts even impinged on the reception history of the conductors Arturo Toscanini and Wilhelm Furtwängler. "Execution" (Auffuihrung, Ausführung) and "interpretation" refer not only to historical phases but equally to cultural realms where reception history is formed. Adorno's essay on the "Mastery of the Maestro" ([1958] 1978) rehashes the alltoo familiar German attitude of superiority that consigns Italian musicians to the realm of execution (unreflected practice of a skill, an activity that never extends beyond refinement of technique) but elevates German musicians to the realm of the spirit, a realm of reflection and exegesis extending far beyond mere technique, an artistic activity that both invokes and unveils the depths of music's enigmatic character-in short, "interpretation" in the strong sense. The contrast is set down in a dichotomous landscape that Bernd Sponheuer

18 Incidentally, Dahlhaus's concert reviews, a selection of which was published in Dahlhaus (2007), reveal not only a qualitative level rarely encountered today but a structure that connects value judgements of performances with conceptual outlines of the work performed rather than presenting them in isolation as opinions of taste. 
(1987) outlined for the nineteenth century in his inaugural dissertation at Kiel, and which persisted well into the twentieth century, at least in Adorno's case (even if he preferred his matrilineal Italian surname Adorno to the patrilineal "Wiesengrund"). Few musicians perform the opening of Brahms's Second Piano Concerto as did Horowitz and Toscanini (1940) - namely, by taking the Allegro non troppo at the specified speed so that the tempo, too, and not just the main horn motif, is understood as part of the exposition. Here execution and interpretation coincide rather than falling asunder, as they do in the recording by Zimerman and Bernstein (1985). ${ }^{19}$ One need only compare Adorno's account with the above recordings and apply reception history to lift the evil spell and elevate the maestro to his well-deserved place in the annals of musical interpretation.

\section{PERFORMANCE}

The theory and practice of "performance" did not emerge in Western musical culture until many years after the deaths of Furtwängler and Toscanini, and its adherents sometimes seem to me like a horde of Messieurs Jourdains who see the world in a fresh light once they discover that they have been speaking prose all their lives without being aware of it. They perform scholarship in the form of "power grabs" in much the same way as politicians, in that they draw strength from it to redefine concepts. It is a matter of greater importance to the history of music and art than one might think. Permit me a slight digression in order to introduce a distinction between two conceptual worlds in the evaluation of conflicts: one that is external, polemical, and contrastive, and another that is internal and concerned with ennoblement. ${ }^{20}$

The latter occurs when a person or institution hopes to secure advantages or gain esteem and profit by changing its name. An example of just such internal conceptual shifts can be found in the field of education. This estimable profession, which has, after all, seen figures of the stature of Plato, Aristotle, Kant, Hegel, and Adorno among its ranks, has suffered a severe loss of prestige through George Bernard Shaw's quip, "Those who can, do; those who cannot, teach." I already touched on this subject earlier with my comment on the hierarchy of creative authors, whose decline (we had landed at the side table of musicology) might well be prolonged if we were to place music teachers still further down the list-let us say, in the doghouse. The internal process of terminological ennoblement might be outlined as follows: after a certain period a professional tag begins to seem threadbare, incapable of justifying salary

19 Compare the extremely slow tempo on the live recording made by Krystian Zimerman and Leonard Bernstein with the Vienna PO in the Vienna Musikverein in October 1984 (Zimerman and Bernstein 1985). Here the tempo of the opening cannot possibly be considered part of an allegro exposition rather than an introduction; it is music from a different sphere.

20 In its classical form, Mephistopheles teaches the Student: "Yes, yes, but don't be bothered overmuch by that. / It's just when sense is missing that a word comes pat / And serves one's purpose most conveniently. / Words make for splendid disputations / And noble systematizations; / Words are matters of faith; as you'll have heard, / One can take no jot nor tittle from a word!" (Faust I, lines 1994-200o, as translated in Goethe [1987] 1998, 60). 
increases or the creation of new jobs. The profession then sets out in search of new words that will, it is hoped, open up fresh territory. A "teacher" hands down useful information to young people, but when he feels his prestige is depleted he calls himself an "instructor." With the further passage of time he switches to a different language and introduces himself as a "pedagogue." When this field, too, seems to have degenerated from an attractive sphere to a quotidian affair, he switches to "educationalist." And when not even this suffices because it seems to lack theoretical underpinnings, he creates the professional label of "educational scientist," a being who today even marches under the banner of "instructional design." A string of concepts of this sort reflects the continuity of a profession in the light of its entropic decline to a mere trade and its periodic renewal through alternative terms with a higher degree of theory-terms that, of course, face the same imminent danger of attrition.

In the case of "performance," however, we are dealing with a matter that I would prefer to classify as external, polemical, and contrastive. What do I mean by this? Here, too, I approach this set of problems from the outside. For decades theatre studies were not an academic pursuit in the strict sense. Many universities lacked a department of theatre studies. It was the literary scholars who led the way. Shakespeare's plays were examined from numerous angles; a huge literature arose on the subject; the generic status of tragedy or comedy, having stood on a par with lyric and epic poetry ever since antiquity, was in no need of a separate discipline to study the dramaturgical or technical practice of theatre productions and the manner in which they received and passed on the works produced. Theatre studies were peripheral even to Aristotle, and for a long time they huddled in the broom closet of academe, despised by literary scholars with their focus on the eternal verities or hermeneutic exegesis of art.

All this changed when the concept of "performance" (performativity, the performative) entered the picture. This is an interesting research topic for the historian of human knowledge, and I can only outline it here. The term arose in a polemical and contrastive spirit because the founding of research fields, institutions, and projects concerned with "the performative" drew on the assumption that what this term was aiming at had never been dealt with at all in earlier academic studies, that fundamentally new things were waiting to be unearthed. The bogeyman to be pilloried was called "text," a category fundamental to literary scholars since the onset of their existence (even Gottsched placed the text above the performance). This can be understood in a great many ways, but also very restrictively. Those who proclaimed the age of the "performative" in human knowledge succeeded, in what was virtually a stroke of genius, in narrowing the concept of text almost ad absurdum. It allowed them to claim that what lay beyond the text was liberation and deliverance and to pursue it as such. By detaching the text of a drama from its potential stageability, it quickly became a corpse awaiting disposal.

Much the same happened in musicology. Now, there is no denying that musicologists devoted too little effort to the sonic and operative dimensions of their art. They failed sufficiently to ponder the scholarly or educational import of the question, "What instrument do you play?" It is a question that their inter- 
locutors from other professions frequently pose, or at least more frequently than "What field are you researching: the music history of the Middle Ages, the eighteenth century, or an orchestra?" But do we ask art historians whether they would rather paint in oils or watercolours or make drawings or sculpture? The notion of meaningful musical activity is evidently linked prima facie to playing an instrument. Music must necessarily be turned into sound. Indeed, Brahms would never have become the "best of all Wagnerians" without the piano, nor would Beethoven have become "Beethoven" if he had lost his hearing in childhood. The silent reading of musical texts is akin to cooking without a stove.

The German "performance" school derived its thrust from the English origin of the term (even today funds in Germany flow for the English-language term "music education," not for musikalische Bildung). In light of this situation, it was able to take hold by turning against the narrow notion of text in a scholarly discipline that probed, with undivided energy, the notated work of music rather than music as it is played, heard, and understood-incontestably the mainstay of cultural interest. It studiously ignored that for decades music researchers had cultivated both the theory and practice of "execution," "recitation," "interpretation," and "performance" as fields of scholarship and could even present a few findings. But the polemical coup won out: the new field was no longer at the mercy of a pathology concerned solely with the lifeless body parts of musical art. One Berlin university, the Free University, put upon to reduce expenses, decided several years ago to scrap its musicology department in favour of theatre studies.

How to outline "performance" in a few deft strokes? It was only at a rather late date that the term entered English musical lexicons at all. It was not included in the first edition of George Grove's Dictionary of Music and Musicians $(1879-89)$ and even failed to find its way into it as late as the fourth edition (Colles 1940). To be sure, Frederick Dorian's History of Music in Performance (1942) was a major step. Finally, the New Grove contained an entry by Howard Mayer Brown and James W. McKinnon (1980) on "performing practice" (a translation of Auffuihrungspraxis), as does the second edition (Brown, Hiley, et al. 2001), though the two-volume book publication based on the entry prefers the title "performance practice" (Brown and Sadie 1989), as does The New Harvard Dictionary of Music (Randel 1986; see also Danuser 1996). An article on "performance" by Jonathan Dunsby (2001) for the second edition of the New Grove seems to expand the concept and to situate it in a more basic context. As long as the terms "performance" or "performance practice" reflect the fields of meaning covered by Aufführung, Ausführung, and Aufführungspraxis in German, peace reigns on the terminological front, particularly as "interpretation" also settled into English technical parlance in the first half of the twentieth century. ${ }^{21} \mathrm{But}$ a conflict has arisen in recent decades as English and American terminological developments were adopted and took hold in German, namely, Performance as an avant-garde multimedia art form and a methodological model in cultural studies.

21 See, for example, Donington (1963), and still earlier Dolmetsch (1915). 
I am not prepared to feebly scuttle Auffuihrung/Ausführung and replace it in German usage with a synonym, Performance. This would be tantamount to a fashionable change of words in which musicology, as a study of culture, would be the loser. The meaning attached to it by the American theorist Edward T. Cone in his book Musical Form and Musical Performance (1968) comes fairly close to Interpretation. Even John Rink and his co-workers in the British project "The Study of Music as Performance" use the term in a highly productive combination of text criticism, performance practice, and interpretation research (see Cook 1999; Rink 2002).

Although German performance research attempts to draw on these British and American trends, Performance in German has naturally acquired the status of an antonym to Interpretation, especially as the term Performanz is also rooted in the theory of speech acts (see Wirth 2002, 63-184). It encompasses only the recent historical accretions to the concept of "performance." Its object is the act of music's realisation, not in the sense of "execution"-as the conversion of a musical text into sound-but in the sense of an action or event that, together with all its factors, is made the focal point of the aesthetic experience. The emphasis, rather than falling on the exegesis of things ill-understood or difficult to grasp (i.e., on hermeneutics), centres on what a recent book title calls the "production of presence" (Gumbrecht 2004). The passage of time that constitutes music is restored to its rights as a fundamental arbiter; music is extracted from its exclusively sonic domain and shifted, with the aid of multimedia, to the focus of a process of presentation that unites the audible with the visual.

The form of music's existence mentioned at the beginning of this paper-an imaginary music residing in the act of reading-is not an object of the performative. Rather, its object is, among other things, music to be listened to, as well as music to be looked at, music to be felt physically and tactilely, music for dancing, music for dreaming. The sound events perceived as a "performance" are noteworthy precisely for their vagueness, their intermedial lack of focus. The performance of music involves acts of visual perception and thus addresses more than just the auditory faculty. The concept of "music theatre" should thus be taken in an etymologically literal sense: music to be looked at. ${ }^{22}$

Performance involves exciting crossovers that bestride the boundaries between avant-garde music, art music, and pop art. Today's art scene is so varied and diverse that such rigid concepts cannot possibly do justice to it. Walter Benjamin's principle of grounding art theologically by extracting it from the act of reception loses validity in the performance culture, which is designed for human apprehension and draws its meaning from its amenability to sensory perception. Thus, the parameters of musical art immediately change.

Greater importance is attached to the visual, bodily, tactile, and kinetic dimensions under which music is made and listened to. The Kronos Quartet, for example, holds concerts in which the placement of the musicians and a sophisticated light show plunge the activities of music-making into a meditative atmosphere. The sounds - the events-no longer stand for themselves in

22 The forms and functions of a concept of "staging" relevant to music are discussed in Danuser (200o). 
the sense of an art intended for the ear alone. They are enveloped and bathed in waves of colour that channel, influence, or even determine the overall aesthetic experience. This is a sacrilege to all adherents of "pure musical art," for the focus on the audible is altered by its visual contextualisation. ${ }^{23}$

What, then, are the defining features of "performance"? They establish music as an action art that remains unique precisely in its performance, its presentation, and cannot be replaced by its reproduction, no matter how successful is DVD technology (though here, too, reproduction is catching up). Music is thus less a revelation of truth than a cultural event that gives its participants the same sort of feelings increasingly conveyed by exhibitions, sound art presentations, perfumes, and the rest. Should we relate these feelings to "beauty"? Perhaps. The performance may be based on a text (in the function of a script), but what is essential is its disconnection from the text. Once music aspires to status in a performance culture, its place in the history of composition, and of interpretation, has become wholly irrelevant. Disconnected from the text, it lacks this basis altogether. It assumes an independent reality and creates its rules on its own terms. The contextualised sound-event applies unreservedly to itself alone. A loss of the reflexivity capable of incorporating the experience into a history of listening and interpretation is offset by a gain in atmosphere and aesthetic immediacy. Perhaps the rise of the performance is a counter-reaction to an ever-expanding culture of musical reproduction. Wherever museums have taken hold, in ever-greater perfection, there is a contrary impulse to stage artistic presence instead of the museum, the event instead of history, sensual aesthetic immediacy instead of the text.

Do the concepts I have invoked really conflict? In this field of musicology, Europe's multilingual cultures, whose common roots, after all, hark back to the days of the Roman Empire, reveal how terms migrate from one language to another, and how central concepts have emerged as predominant since the eighteenth century, from French via German to English. The task of terminological history is to reconstruct these developments as clearly and comprehensively as possible. We must not allow a position to take hold as a new paradigm through polemical exclusion alone. Its claims must be bolstered by arguments and distinctions. To be sure, the characteristics of the definitions of these terms can also be placed in a harmonious relation in which, rather than squaring off as antagonists, they complement one another without loss of substance. But political theory teaches us that such harmonious frames of reference are more likely to be an intellectual daydream than factual reality. For this reason the struggle for words, the clash of terminologies, will continue in the future, even if we were to grant top priority to one of these models: "interpretation."

23 Kronos Quartet: In Accord, a film by Mandred Waffender released on DVD (Kronos Quartet 1998), features Pérotin's four-voice organum Viderunt omnes played in a string-quartet arrangement by the Kronos Quartet. The violinist Daniel Hope, who recently performed in a Berlin synagogue, would seem to be aiming at something similar with his art, to judge from Dörte Schmidt's inaugural lecture at Berlin University of the Arts on 30 October 2007. That these are not just isolated instances is shown by the concert hall of the Cité de la Musique, which began operations in Paris in the 1990s. The hall is illuminated with various coloured lights to lend the music a visual and atmospheric context that sets it apart from everyday reality and singles out the context as a special location. 


\section{Hermann Danuser}

REFERENCES

Adorno, Theodor W. (1958) 1978. "Die Meisterschaft des Maestro." In Musikalische Schriften I-III, edited by Rolf Tiedemann, vol. 16 of Gesammelte Schriften, 52-67. Frankfurt am Main: Suhrkamp. First published $195^{8}$ (Merkur 12 [10]: 924-37); republished in Klangfiguren: Musikalische Schriften I (Frankfurt am Main: Suhrkamp, 1959). Translated by Rodney Livingstone as "The Mastery of the Maestro" in Sound Figures (Stanford, CA: Stanford University Press, 1999), 40-53.

- 2001. Zu einer Theorie der musikalischen Reproduktion: Aufzeichnungen, ein Entwurf und zwei Schemata. Edited by Henri Lonitz. Nachgelassene Schriften 1.2. Frankfurt am Main: Suhrkamp. Translated by Wieland Hoban as Towards a Theory of Musical Reproduction: Notes, A Draft, and Two Schemata (Cambridge: Polity Press, 2006).

Arditti String Quartet. 2007. Gran Torso: Musik für Streichquartett. On Helmut Lachenmann: Streichquartette. Kairos, $0012662 \mathrm{KAI}$, compact disc.

Ballstaedt, Andreas, and Hans-Joachim Hinrichsen, eds. 2008. Werk-Welten: Perspektiven der Interpretationsgeschichte. Schliengen, Germany: Edition Argus.

Bent, Margaret. 1983. "Resfacta and Cantare super librum." Journal of the American Musicological Society 36 (3): 371-91.

Bockmaier, Claus, ed. 2009. Beiträge zur Interpretationsästhetik und zur HermeneutikDiskussion. Laaber, Germany: LaaberVerlag.

Borio, Gianmario, ed. 2009. Melodia, stile, suono. Vol. 3 of Storia dei concetti musicali. Rome: Carocci.

Borio, Gianmario, and Carlo Gentili, eds. 2007a. Armonia, tempo. Vol. 1 of Storia dei concetti musicali. Rome: Carocci. -, eds. 2007b. Espressione, forma, opera.

Vol. 2 of Storia dei concetti musicali. Rome: Carocci.

Brown, Howard Mayer, David Hiley, Christopher Page, Kenneth Kreitner, Peter Walls, Janet K. Page, D. Kern Holoman, Robert Winter, Robert Philip, and Benjamin Brinner. 2001. "Performing Practice.” In The New Grove Dictionary of Music and Musicians, edited by Stanley
Sadie, 2nd ed., 29 vols., 19:349-88. London: Macmillan.

Brown, Howard Mayer, and James W. McKinnon. 1980. "Performing Practice." In The New Grove Dictionary of Music and Musicians, edited by Stanley Sadie, 20 vols., 14:370-93. London: Macmillan.

Brown, Howard Meyer, and Stanley Sadie, eds. 1989. Performance Practice. 2 vols. New Grove Handbooks in Music. London: Macmillan.

Brüstle, Christa, and Clemens Risi. 2008. "Aufführungsanalyse und -interpretation: Positionen und Fragen der 'Performance Studies' aus musikund theaterwissenschaftlicher Sicht." In Ballstaedt and Hinrichsen 2008, 108-32. Colles, H. C., ed. 1940. Grove's Dictionary of Music and Musicians. 4 th ed. 5 vols. + suppl. London: Macmillan.

Cone, Edward T. 1968. Musical Form and Musical Performance. New York: Norton. . 1981. "The Authority of Music Criticism." Journal of the American Musicological Society 34 (1): 1-18. Reprinted in Edward T. Cone, Music: A View from Delft; Selected Essays, edited by Robert P. Morgan (Chicago: University of Chicago Press, 1989), 95-112.

Cook, Nicholas. 1999. "Analysing Performance and Performing Analysis." In Rethinking Music, edited by Nicholas Cook and Mark Everist, 239-61. Oxford: Oxford University Press.

Dahlhaus, Carl. 1967. "Aufführungspraxis." In Eggebrecht 1967b, 59-61.

- - 2007. Varia. Vol. 10 of Gesammelte Schriften, edited by Hermann Danuser. Laaber, Germany: Laaber-Verlag.

Danuser, Hermann. 1992a. "Einleitung." In Danuser 1992b, 1-72.

_—_, ed. 1992b. Musikalische Interpretation. Vol. 11 of Neues Handbuch der Musikwissenschaft, edited by Carl Dahlhaus. Laaber, Germany: LaaberVerlag.

-_—. 1994-2007a. “Interpretation.” In Finscher 1994-2007, Sachteil 4:1053-69. - 1994-2007b. "Vortrag." In Finscher 1994-2007, Sachteil 9:1817-36. - 1996. "Zur Aktualität musikalischer Interpretationstheorie.” In Musik befragt, Musik vermittelt: Peter Rummenhöller zum 
6o. Geburtstag, edited by Thomas Ott and Heinz von Loesch, 75-90. Augsburg: Wissner.

—. 2000. "Inszenierte Künstlichkeit: Musik als manieristisches Dispositiv." In Manier und Manierismus, edited by Wolfgang Braungart, 131-67. Tübingen: Niemeyer.

-_—. 2014. "Exekution-

Interpretation-Performance: $\mathrm{Zu}$ einem begriffsgeschichtlichen Konkflikt.” In Gesammelte Vorträge und Aufsätze, edited by Hans-Joachim Hinrichsen, Christian Schaper, and Laure Spaltenstein, 4 vols., 1:530-48. Schliengen, Germany: Argus.

Dolmetsch, Arnold. 1915. The Interpretation of the Music of the XVIIth and XVIIIth Centuries: Revealed by Contemporary Evidence. London: Novello.

Donington, Robert. 1963. The Interpretation of Early Music. London: Faber and Faber.

Dorian, Frederick. 1942. The History of Music in Performance: The Art of Musical Interpretation from the Renaissance to the Present Day. New York: Norton.

Drosdowski, Günther, ed. 1977. Duden: Das grosse Wörterbuch der deutschen Sprache. 6 vols. Mannheim: Bibliographisches Institut.

Dunsby, Jonathan. 2001. "Performance." In The New Grove Dictionary of Music and Musicians, edited by Stanley Sadie, 2nd ed., 29 vols., 19:346-49. London: Macmillan.

Eggebrecht, Hans Heinrich. 1967a. "Interpretation." In Eggebrecht 1967b, 408-9.

——, ed. 1967 b. Riemann Musiklexikon: Sachteil. Mainz: Schott.

Finscher, Ludwig, ed. 1994-2007. Die Musik in Geschichte und Gegenwart. 2nd ed. 28 vols. Kassel: Bärenreiter; Stuttgart: Metzler.

Fulda, Adam von. (1490) 1963. De Musica. In Scriptores ecclesiastici de musica sacra potissimum, edited by Martin Gerbert, 3 vols., 3:329-81. Hildesheim: Olms. Fulda's text written 1490 . Gerbert's edition first published 1784 (St. Blasien: Typis SanBlasiansis).

Goethe, Johann Wolfgang. (1987) 1998. Faust, Part One. Translated by David Luke. Oxford: Oxford University Press. First published 1808 as Faust. Der Tragödie erster Teil (Tübingen). Translation first published 1987 (Oxford: Oxford University Press).

Göllner, Theodor, ed. 1980. Notenschrift und Aufführung: Symposium zur Jahrestagung der Gesellschaft für Musikforschung 1977 in München. Tutzing, Germany: Schneider.

Gottschewski, Hermann. 1996. Die Interpretation als Kunstwerk: Musikalische Zeitgestaltung und ihre Analyse am Beispiel von Welte-Mignon-Klavieraufnahmen aus dem Jahre 1905. Laaber, Germany: LaaberVerlag.

Grimm, Jacob, and Wilhelm Grimm. 1854-196o. Deutsches Wörterbuch. 16 vols. in 32 subvols. Leipzig: Hirzel.

Grove, George, ed. 1879-89. A Dictionary of Music and Musicians. 4 vols. London: Macmillan.

Gumbrecht, Hans Ulrich. 2004. Production of Presence: What Meaning Cannot Convey. Stanford, CA: Stanford University Press.

Gutknecht, Dieter. 1994-2007. "Aufführungspraxis." In Finscher 1994-2007, Sachteil 1:954-86.

Haas, Robert. 1931. Aufführungspraxis der Musik. Vol. 8 of Handbuch der Musikwissenschaft, edited by Ernst Bücken. Wildpark-Potsdam: Akademische Verlagsgesellschaft Athenaion.

Hinrichsen, Hans-Joachim. 1999. Musikalische Interpretation: Hans von Bülow. Beihefte zum Archiv für Musikwissenschaft 46. Stuttgart: Steiner.

—__. 2008. "Furtwängler und Schumann: Überlegungen zum Gegenstand der Interpretationsforschung.” In Ballstaedt and Hinrichsen 2008, 44-71.

Horowitz, Vladimir (pianist), and Arturo Toscanini (conductor). 1940. Brahms: Piano Concerto No. 2. Performed by the NBC Symphony Orchestra, recorded at Carnegie Hall, New York, 9 May 1940. Re-released on Brahms: Piano Concerto No. 2; Tchaikovsky: Piano Concerto No. 1. Naxos Historical, 8.110671, 2002, compact disc.

Jauss, Hans Robert. 1991. "Rückschau auf die Rezeptionstheorie: Ad usum musicae scientiae." In Rezeptionsästhetik und Rezeptionsgeschichte in der Musikwissenschaft, edited by Hermann Danuser and Friedhelm Krummacher, 13-36. Laaber, Germany: Laaber-Verlag.

Koch, Heinrich Christoph. (1802) 1985a. "Ausführung." In Musikalisches Lexikon, 187-93. Hildesheim: Olms. First 


\section{Hermann Danuser}

published 1802 (Frankfurt am Main: August Hermann d. J.).

$$
\text { . (1802) 1985b. "Vortrag." In }
$$

Musikalisches Lexikon, 1729-30.

Hildesheim: Olms. First published 1802

(Frankfurt am Main: August Hermann d. J.).

Kraus, Beate Angelika. 2008.

"Interpretationsgeschichte

im Spannungsfeld zwischen

Rezeptionsforschung und

Aufführungspraxis." In Ballstaedt and

Hinrichsen 2008, 13-26.

Kronos Quartet. 1998. Kronos Quartet: In Accord. Directed by Mandred Waffender. Halle (Saale): Arthaus Musik, 100050, DVD.

Kropfinger, Klaus. 1994-2007. "Rezeptionsforschung." In Finscher 1994-2007, Sachteil 8:200-24.

Neuwirth, Olga. 2006. "Hinter den Spiegeln Der Komponist ist ein Alien geworden oder: Salzburgs Umgang mit den Künstlern.” In Frankfurter Allgemeine Zeitung 174 (29 July): 38

Pompilio, Angelo, Lorenzo Bianconi, F. Alberto Gallo, and Donatella Restani, eds. 1990. Atti del XIV congresso della Società Internazionale di Musicologia: Trasmissione e recezione delle forme di cultura musicale [Bologna, 27 August-1 September 1987]. 3 vols. Turin: EDT.

Randel, Don Michael, ed. 1986. "Performance Practice." In The New Harvard Dictionary of Music, 624-25. Cambridge, MA: Harvard University Press.

Reidemeister, Peter. 1988. Historische Aufführungspraxis: Eine Einführung. Darmstadt: Wissenschaftliche Buchgesellschaft.

Riemann, Hugo. 1887. Musik-Lexikon. 3 rd ed. Leipzig: Hesse.

. 1895. "Das Überhandnehmen des musikalischen Virtuosentums.” In Vol. 1 of Präludien und Studien: Gesammelte Aufsätze zur Ästhetik, Theorie und Geschichte der Musik, 3-12. Leipzig: Seeman.

Riethmüller, Albrecht. 1998. “'Interpretation' in der Musik: Eine Skizze.” In

Interpretation, by Gerhard Funke, Albrecht
Riethmüller, and Otto Zwierlein, 17-30. Stuttgart: Steiner.

Rink, John. 2002. "Analysis and (or?) Performance." In Musical Performance: A Guide to Understanding, edited by John Rink, 35-58. Cambridge: Cambridge University Press.

Schilling, Gustav, ed. (1835-42) 2004. Encyclopädie der gesammten musikalischen Wissenschaften oder Universal-Lexicon der Tonkunst. 7 vols. Hildesheim: Olms. First published 1835-42 (Stuttgart: Köhler).

Schnebel, Dieter. 1969. Mo-No: Musik zum Lesen. Cologne: DuMont Schauberg.

Sponheuer, Bernd. 1987. Musik als Kunst und Nicht-Kunst: Untersuchungen zur Dichotomie von "hoher" und "niederer" Musik im musikästhetischen Denken zwischen Kant und Hanslick. Kassel: Bärenreiter.

Sulzer, Johann Georg. 1771/74. Allgemeine Theorie der Schönen Künste. 2 parts. Leipzig: Weidmanns Erben und Reich.

Walther, Johann Gottfried. (1732) 1953. Musikalisches Lexikon; oder, Musikalische Bibliothek. Edited by Richard Schaal. Kassel: Bärenreiter. First published 1732 (Leipzig: Wolffgang Deer).

Widmann, Joseph Viktor. (1898) 1980. Erinnerungen an Johannes Brahms. Zürich: Rotapfel. First published 1898 as Johannes Brahms in Erinnerungen (Berlin: Paetel). Translated by Dora E. Hecht in Recollections of Johannes Brahms (London: Seeley, 1899).

Wirth, Uwe, ed. 2002. Performanz: Zwischen Sprachphilosophie und Kulturwissenschaft. Frankfurt am Main: Suhrkamp.

Zaminer, Frieder. 1973. "Über die Herkunft des Ausdrucks 'Musik verstehen.” In Musik und Verstehen: Aufsätze zur semiotischen Theorie, Ästhetik und Soziologie der musikalischen Rezeption, edited by Peter Faltin and Hans-Peter Reinecke, 314-19. Cologne: Arno Volk.

Zimerman, Krystian (pianist), and Leonard Bernstein (conductor). 1985. Brahms: Klavierkonzert No. 2. Performed by the Vienna Philharmonic Orchestra. Deutsche Grammophon, 415359-2, compact disc. 


\title{
Monumental Theory
}

\author{
Thomas Christensen \\ University of Chicago
}

In recent years, the "regulative work concept" that has governed so much musical discourse over the last two centuries has come under sceptical scrutiny. ${ }^{1}$ This work concept, along with all its attendant corollaries-the reification of the composer as autonomous "genius"; the formation of a musical "canon"; the fetishising of an authoritative and self-sufficient musical score; the ethical obligation for the most faithful musical interpretation (Werktreue) of a score-may hardly be said to have been laid to rest; but it is clearly one that ought no longer be invoked without critical qualifications by any responsible scholar.

In the following essay, I want to see whether some of the same qualifications might also be asked of music theory texts. This might, at first, sound like an odd proposition. After all, we normally don't think of music theory the way we might of musical artworks; music theorists are rarely placed on the same creative level as the great composers (unless, of course, they happen to be one and the same person). And probably no one will confuse the experience of listening to a symphony in a concert hall with the reading of a theory text in a public library (not to mention as a digital reproduction on a home computer). Yet as I hope to persuade here, there are nonetheless many striking similarities in the way we treat the corpus of elite music theory texts and the scores of canonical music artworks. And many of the challenges that writers such as Goehr have raised in regard to the ontological status of the "regulative work concept" are ones that might also be raised in regard to works of music theory. But for reasons I hope to analyse, the ontological status of the music theory text has received virtually no diagnosis, let alone serious challenge, among scholars today.

Musicologists often speak casually of things such as "Schenker's theory" or "Rameau's theory," indexing these to canonical texts in which these theories are purportedly represented: Der freie Satz or the Traité de l'harmonie. Most literate musicians who might concern themselves with these matters have a clear enough idea of what we mean by those designations. Theory is understood

\footnotetext{
DOI http://dx.doi.org/10.11116/9789461661883.ch10

The present essay is a revised and shortened version of an article that Thomas Christensen published earlier: Christensen (2011). This latter publication originally began as a presentation to the Mannes Institute for Advanced Studies in Music on 24 June 2011. A subsequent revised and abridged version of the paper was delivered (in German) as the keynote address of the German Gesellschaft für Musiktheorie in Berne, Switzerland on 3 December 2011 and was further distilled in a paper presented at the Society for Music Theory in New Orleans on 3 November 2012.

1 The touchstone for this argument is of course Goehr ([1992] 2007).
} 
philosophically as a kind of systematisation of ideas conceived by an author that is written down and contained within a given text. And this definition, as simple as it is, applies to any of the three major subgenres of music theoretical writing found in the West: speculative, regulative (practical), or analytic. ${ }^{2}$

Yet is the full meaning and identity of the theory text as self-evident as all that? Is the elite status we tacitly grant certain texts-and their authors-so stable? And might there be something in the actual practice of music theory outside the corpus of canonical printed texts in our libraries? In short, I am asking whether many of the challenges that Goehr and others have made to the musical work concept might also be made to a "regulative theory concept."

There are many good reasons for doing so. While it is true, as I have suggested, that no music theory text will ever be confused phenomenologically with any canonical musical artwork, theory nonetheless has played an important part in the unfolding drama that is the story of Western music history. Music theory is a repository of some of the most serious and influential thinking about music that we have, a lineage that can be traced back to antiquity, long before we even had any notation of music. And music theory-in all its complexity and diversity - has been foundational to the musical training of musicians since the Middle Ages. Among other things, theory has offered us conceptual models, rules, and heuristics that have shaped how musicians understand and talk about music, how music "should go." In many important social ways, music theory has scripted the very regulative norms within which — and perhaps against whichthe monumental musical artwork could emerge. It is interesting that Goehr dates the emergence of the work concept in music to around 1800 , which is also the time the modern notion of music theory emerges. (I have elsewhere identified this emergence with the writings of Sulzer and Forkel in the last quarter of the eighteenth century [Christensen 2002, 9]). So while I do not wish to make overinflated claims about the importance or value of music theory in the broader culture of music, at the same time I will insist that the collective writings we label as music theory represent an influential body of literature whose status and function deserves attention and critical scrutiny.

There are at least two ways that we might undertake such critical scrutiny of music theory. The first might be to consider the authorship of theory. While, as I said, we often casually talk about "Rameau's" theory or "Schenker's" theory, it turns out that the provenance of many theoretical ideas cannot be so firmly tethered to a given author. And while this might be obvious in the case of an anonymous treatise from the thirteenth century, it also can apply to ideas whose genealogies seem firmly attached to a given text. The ownership of "music theory" is rarely a straightforward question.

The second place in music theory we might examine critically is the music text itself. Like the musical score, texts of music theory are hardly self-evident objects. The actual status of a text can be complicated by its history: its origins, its publication (or not), and its subsequent reception. As we know, many theoretical ideas are formulated and disseminated outside the text through oral

2 On these three branches of music theory, see Christensen $(2002,13-14)$. 
transmission or other, non-discursive means. Theory, then, might be seen as less a codification of fixed doctrines attributable to a single author and codified within a single text than something that is far more fungible and dynamic in practice. I will return to this point further on.

For now, my intent is to prod us to rethink the central role we accord the monumental theory text in our histories of music theory. ${ }^{3} \mathrm{~A}$ decentring of the text may be more sympathetically received today given how digital technologies are radically and rapidly changing the way knowledge is authored, communicated, and consumed. But I will resist drawing overmoralising conclusions from my study. For my primary argument is that there have always been problems of authorial agency and textual constitution in the field of music theory, well before the age of the internet. One might not guess this given the authority we grant to the printed text in defining our discipline (and indeed, in reconstructing its history). But, as I hope to persuade, all those tomes lined up in our research libraries between $\mathrm{MT}_{5}$ and $\mathrm{MT}_{55}$ should not be presumed to represent the whole historical discipline of music theory.

To show what some of these qualifications could be, I want now to turn briefly to four contrasting case studies. I will begin with what is undoubtedly the most influential text of medieval music theory-Boethius's De institutione musica (c.500-505) - by looking briefly at its complex compilation and reception history. I will then jump ahead to the eighteenth century and consider how elements of Rameau's music theory were orally circulated in early eighteenth-century Germany. As a third case, I will then move back in time and consider a school of chant theory that was also communicated orally in the fifteenth century and has been reconstructed through subtle philological forensics. I will then conclude with a look at a "covert" pedagogy of partimenti performance, once again from the eighteenth century, that has recently been gaining greater attention, and I will consider what it says about the limits of authorial agency and textual representation in music theory.

\section{BOETHIUS AND DE INSTITUTIONE MUSICA: JUST WHAT GOES INTO A CLASSICAL MUSIC THEORY TEXT ANYWAY?}

If there is a single text on which we might bestow the status of a "blockbuster" in the history of music theory, then it surely should be De institutione musica of Boethius. For almost a full millennium, this text was considered the most authoritative and important work of music theory known; indeed, we could say it helped define the very earliest notions of what "musica theorica" was. But we will see that even a work that has attained such monumental status may not be all that it seems.

Compiled, as far as we can determine, in the first decade of the sixth century, the Institutio first began to be cited (and circulated in copy) some three centuries later during the Carolingian period. It quickly assumed the status of

3 In this sense, my aim to destabilise the notion of monumentality in music theory skirts some of the aesthetic and nationalistic issues diagnosed by Alex Rehding in his wonderful recent monograph (Rehding 2009). 
a canonical work, its author the most important auctoritas among ancient musical writers. Already in the ninth century, the Carolingian theorist Aurelian of Réôme voiced a commonly shared sentiment when he called Boethius the "vir eruditissimus" and "doctissimus." (As late as 1487 , the Italian theorist Nicolò Burzio defended Boethius as the "Monarch of Musicians.") As but one empirical indication of his importance, we might note there are over 137 extant manuscript copies of Boethius's De institutione musica text from the Middle Ages-far more than exist for any other single musical text (Bower 1988). And this manuscript tradition continued (with some notable fluctuations to be discussed) until the first print publication of the Institutio musica in 1492.

The importance of Boethius's work to the Middle Ages was manifold. First of all, it conveyed with more detail and authority than any other extant source the classical Greek tonal system to its Latin readers: pitch and interval names, scale systems, tonoi, and genera. (But we must always keep in mind that Boethius himself was removed by at least half a millennium from the period in which any of these concepts might have had any real vitality.) His highly sophisticated mathematical discussion of interval ratios and proportions remained authoritative - if often vexing - for medieval readers until at least the fourteenth century. Moreover, Boethius introduced an alphabetic (Alypian) notation system that would prove catalytic for Carolingian theorists.

For now, though, it is enough to underscore that the greatest legacy of Boethius's text was simply the prestige and legitimisation it gave to music as a subject of philosophical inquiry within the seven artes liberales. Along with the disciplines of arithmetic, geometry, and astronomy, music was part of the great "quadrivium" of numerical sciences (the other canonical grouping being the "trivial" subjects of grammar, rhetoric, and dialectics). Of course his conception was fully a Platonic one in which musica was understood as an abstract science of discrete numerical relations. It had little to do with anything that we would consider "practical" music making. In his famous disciplinary hierarchy, musica mundana stood at the head of musical study as the harmony of heavenly bodies. It was followed by musica humana - the harmony of the human soul and body - and finally musica instrumentalis - actual sounding music. The first two categories constituted musica and were worthy of study and contemplation by the true philosopher of music (which he designated simply as a musicus), while the later discipline was the province of the untutored singer (what some Carolingian theorists would designate condescendingly as a cantor), clearly a subject beneath the dignity of the musicus.

With its powerful rhetoric and intimidating array of classical and mathematical learning, its clear, exegetical ordering (characteristic, as Leo Schrade [1947] has noted, of the ancient Greek genre of the protreptikos - an exhortation to the study of philosophy - as well as an eisagogé - an introduction to a given discipline), it is not surprising that upon its reappearance during the ninth-century Carolingian revival of learning, De institutione musica quickly assumed the position of a canonical text (ibid.). As the first European universities were established in the late twelfth and thirteenth centuries, it became prescribed as a required text, a position it maintained in some institutions as late as the seven- 
teenth century. A large preponderance of learned writers on music throughout the Middle Ages were aware of Boethius's work and, in many cases, drew from it liberally for their own writings.

Yet if we look closer at this picture, a more complex story emerges that might lead us to re-examine the authority — and autonomy — of Boethius's treatise in the Middle Ages. This complexity stems from a range of codicological questions regarding the text's origins, compilation, and reception history. As these are problems that are endemic to the overall manuscript culture of the Middle Ages-and, as I will argue, to some degree for published texts of music theory as well-it will perhaps be of value here to pause briefly and review what some of these are, problems that are relevant, mutatis mutandis, to most other texts of musical literature that confront the music theorist.

To begin with, there is the basic philological problem of simply determining what the authoritative text of De institutione musica is. As with virtually all other writings of the Middle Ages, we do not have an original autograph manuscript to consult. (The first autographed copies of a music theory text in the Middle Ages that have survived are only from the fifteenth century [Bernhard 199ob, 67]). In the case of Boethius's work on music, the earliest manuscript we have is from the late ninth century. But simply because a copy is prior in a stemmatic reconstruction, it need not necessarily be the most reliable. Many of the earliest manuscripts seem to be corrupted by copying errors, omissions, additions, or decay and mutilation over time. (A later manuscript could well be based on a more authoritative earlier copy that is now lost.) It is rare to find two copies of the text that correspond in all details; and in many cases, the variances are substantive.

Thanks to the philological work of several generations of medieval scholars, we now can reconstruct as close as we may ever get to an authoritative recension of Boethius's work. Yet this still may not bring us any closer to what its medieval readers knew. For many of the surviving copies of the work are only partial in content, containing often just the first one or two "books" of the text.

Still, even for those copies that contain the "complete" five books (amounting to about two-thirds of the surviving manuscript copies), Calvin Bower (1989, xxxviii) has plausibly argued that there are at least two now-lost books that were probably meant to conclude the original text. Then again, De institutione musica seems to have been conceived as but one treatise among four that would each detail the quadrivial sciences, although none of these treatises survive save for fragments of the arithmetic treatise. How would reading the music part within its broader (or narrower) intellectual context and programme change how one understands its arguments?

As it turns out, Boethius's text was often found copied in single codices along with excerpts from Cassiodorus's Institutiones, a short treatise entitled "Commemoratio brevis de tonis et psalmis modulandis," and the so-called Enchiriadis treatises, musica and scolica. These groupings are so prevalent among surviving tenth-century codices that scholars have suggested it likely represents a tradition of Carolingian pedagogy (Bernhard 199ob, 70). 
The compilation of various writings within a single codex was in fact commonplace in the Middle Ages. Often, just single sections of a text were excerpted-and just as often without authorial attributions. But it turns out that many canonical "treatises" in the Middle Ages are nothing but compilationes of such excerpts, good examples being the Breviarium of Frutolf of Michelsberg (late eleventh century) or the so-called Berkeley manuscript (fourteenth century). Still, a compilation could be more than a random collection of excerpts; a skilled compiler knows not only which texts to draw from but how to strategically order them (ordinatio) to create an effective pedagogical curriculum (Meyer 2001, 52, 161).4

If Boethius's own writings were frequently drawn upon by his admirers throughout the Middle Ages, we should also not overlook that he too was standing on the shoulders of giants. For it seems that a good deal of what Boethius wrote was actually a translation (with commentary) from a now-lost work of Nicomachus, the Eisagoge musica (constituting substantial portions of Books 1 through 4), the Euclidian Sectio canonis (Book 4), and Ptolemy's Harmonica (Book 5). Obviously, concepts of authorship, not to say originality and plagiarism, had quite differing values fourteen hundred years ago than in our age. To borrow, excerpt, and perhaps even fully appropriate a text without citation was both acceptable and commonplace for an "author." Yet this does underscore for us today the fragility of textual authority for many medieval writings.

And then there is the vexing question of textual accretion and additions. Many copies of Boethius's texts-as with other canonical manuscripts of the Middle Ages-are laden with glosses (marginalia comments and textual annotations). These glosses range from short grammatical, lexical, or etymological notations to surprisingly extensive commentaries, exempla, elaborations, illustrations, questions, disputations, or explanations (especially of his difficult mathematics) (Bernhard and Bower 1993-2011; also see Bernhard 1990c). To view these glosses as mere appendages cluttering the "authentic" text of Boethius is woefully to devalue the potential insight they might offer us. When carefully studied, glosses may reveal a reception record, if you will, of the text over many generations of manuscript copies. In many cases, a persistent gloss might eventually become incorporated within the text by scribes during the copying process, in essence becoming part of De institutione musica and its reception history.

I have quickly rehearsed these many problems of the textual codicology and reception of Boethius's De institutione musica as it helps to underscore the precariousness of the written text in medieval manuscript culture, what the medieval scholar Paul Zumthor (1972) has referred to as a manuscript's mouvance. Disentangling the many sedimentary layers of commentary, borrowings, interpolation, and glossa in a text such as that of Boethius requires exquisite philological hermeneutics on the part of the scholar. But if the case of Boethius's

4 Although it is well to keep in mind that not all codices will necessarily show the same level of integration. The incoherence of a "text" such as Coussemaker's "Anonymous XI" can only be explained to result from the compilation of a large number of unrelated excerpts by some scribe that Coussemaker wrongly presumed must have represented a unified whole (Balensuela 2001, 698). 
treatise is a particularly complex and rich one, the cautionary lessons it teaches us are worth keeping in mind when attempting to assess any other music theory text from the Middle Ages. The full meaning of De institutione musica is not revealed simply by the reconstruction of some original and inviolate recension, no matter how rigorous the philology, but also through its unfolding reception, interpretation, and absorption by generations of readers spanning almost a thousand years.

\section{ORALITY IN MUSIC THEORY: THE EARLY RECEPTION OF RAMEAU IN GERMANY}

Boethius's Institutio offers a forceful reminder that music theory texts are used by readers. They are not autonomous objects existing in some Platonic ether of great ideas. They are social objects whose uses-or perhaps abuses?-give them a dynamic, fungible quality. One of the lessons of historical hermeneutics is that theory can never be understood simply as a fixed doctrine; for real understanding and meaning to emerge, a theory needs to be applied in practical settings. Whether it is the interpretation of a Biblical text, a clause in the Constitution, or, yes, a passage from a music theory text, one must test it through application (see Christensen 1993). In music theory, those kinds of applications have long been institutionalised in the various pedagogical settings in which theory comes into play: a professor teaching harmonic analysis in a college classroom, a choir director conducting singers in a monastery or chapel, or an instrumental instructor giving private lessons in a bourgeois parlour.

As soon as we place music theory texts in these institutional settings, something used by teachers and students with varying pedagogical agendas, it becomes clear how much "theorising" takes place around the edge of the printed text or manuscript. This is a phenomenon that I have called "hidden" theory (see Christensen 2011). It is not hidden in the sense that it is opaque or occult in nature. Rather, it is hidden in the sense that much of it remains unrecorded-it is the myriad ideas, intuitions, and applications that readers take from the text (or impose upon it) that might find expression (if at all) orally.

It is odd that music theorists don't seem to acknowledge more directly the importance and ubiquity of orality in our history. After all, many of the greatest theoretical "inventions" were ones designed to facilitate the memorisation and transmission of musical knowledge without using textual means. This was surely so in premodern history, when most musicians were illiterate and had no use for (let alone access to) manuscripts or printed texts. One needed a master of instruction, and most texts were aimed at such a master who would then pass on the teachings-apply them if you will-to his choirboys. This was so with that most famous of medieval theoretical mnemonics, the Guidonian "hand." The hand was a means by which illiterate singers for over half a millennium learnt the topography of diatonic pitch space and modal theory. But it is not just a question of literacy in the premodern period. 
Let me come back to the question of Rameau's music theory. Most of us today have few qualms in locating Rameau's revolutionary idea of the basse fondamentale in his first publication from 1722, the Traité de l'harmonie. But for any of us who have tried to wade through this weighty treatise-whether in the original French or in a translation-the challenges it poses are formidable. Not only does Rameau repeat himself endlessly and get lost in myriad digressions and cul-de-sacs, he often offers muddled and even contradictory arguments that can leave the reader bewildered and lost. (One is inclined to believe Rousseau, who wrote in his Confessions that he started to read the Traité as a youth during a convalescence but quickly had to give up for fear of it causing a relapse!)

Still, many of Rameau's ideas quickly attracted the attention and admiration of some musicians. But it seems not all of them learned these ideas by reading Rameau's publications. This was certainly the case in Germany in the second quarter of the eighteenth century, where we find many of Rameau's most consequential notions circulating long before Marpurg's efforts after $175^{\circ}$ to translate and promote the Frenchman's theory. And the source of this information in this particular case can be identified. It was Johann Nikolaus Bach (1669-1753).

Johann Nikolaus Bach, a second cousin to a certain Leipzig cantor of the same surname, was a popular music teacher at the University of Jena in the early part of the eighteenth century. There is not a single surviving publication or even manuscript that we may attribute to him. Yet the testimony of his many students suggests he was one of the most important and influential music theorists of his day. Later music theorists who did publish their own works (including Friedrich Erhard Niedt, Johann Georg Neidhardt, Jakob Adlung, Johann Philipp Treiber, and especially Christoph Gottlieb Schröter) credited the Jena Bach both with instilling an interest in music theory and with providing ideas for their own appropriation. Schröter, whose own treatise of thoroughbass was published only in 1772 , credited many of his ideas to his studies with Bach a half-century earlier. ${ }^{5}$

In his treatise, Schröter acknowledged that, while studying with Bach in 1724, he learned about the seventh chord built upon "Chordam V" as the foundation of all four-part composition (Schröter 1772, x). ${ }^{6}$ Even more revealingly, we learn that Bach attributed this to "ein Franzose, Namens Mr. Rameau." It is noteworthy, of course, that we have here evidence of Rameau's ideas already being circulated in Germany just two years after the publication of his Traité de l'harmonie appeared in print. (As I mentioned above, Rameau's ideas were never overtly acknowledged and appropriated in Germany until the 175 os, primarily through the advocacy of Marpurg.) But, crucially, it was not the Traite that was circulated. Bach (according to Schröter's account) himself only learned about Rameau's ideas by word of mouth-"mundlich gegebene" (see Christensen 1996).

5 For the complex history of Schröter and his own adaptations of Rameau, see Christensen (2011, 178-80).

6 By the way, this is the earliest use of Roman numerals by a music theorist to designate scale degrees of which I am aware. Here is a clear instance when print helps to establish the claims of priority and authorship. 
It's hard to know precisely just what it was that Bach got out of Rameau, but we might deduce that Bach was teaching something along the lines of chordal inversion to his students, as well as a simple scale degree theory, long before Rameau published anything on the topic in 1722 . Friederich Niedt credits Nikolaus Bach with knowledge of the harmonic triad already in 1710 (Niedt 1710). Clearly, musicians were becoming self-consciously aware of "chords," and were thinking about ways chords related to one another. So perhaps Rameau only confirmed ideas Bach had been thinking about. If this is so, then Bach represents just one tributary of an important theoretical tradition that was propagated orally. We can only speculate what the topography of eighteenth-century music theory would have looked like had Nikolaus Bach published anything systematically.

Of course, Rameau's theory too was built upon many ideas that were long "in the air." For, as I have elsewhere documented, it turns out that virtually every piece of Rameau's theory as articulated in his Traité de l'harmonie of 1722 had precursors in earlier pedagogical traditions. His arguments for the generation of the triad on the monochord return to a venerable tradition of canonist procedures cultivated in the seventeenth century; his formula positing the equivalence of chordal inversions is based on a rubric invoked unsystematically by an earlier generation of thoroughbass pedagogues; and the notion of a generative root had already been adumbrated by Mersenne in the seventeenth century (or perhaps even Aristotle some two thousand years before that) (see Christensen 1993). In many ways, Rameau's genius was more of synthesiser than of inventor.

The case of Nikolaus Bach is only one of dozens of examples we could cite where pregnant theoretical ideas can be said to be "sloshing around" in musical culture: from Pythagorean ideas of number in early antiquity to dualistic thought in the nineteenth century to serial theory in the twentieth century, music theory has countless ideas with complex pedigrees that are hard to sort out. ${ }^{7}$ An obsession with genealogy and trying to trace some idea back to its origins (ideally to a single text) obscures the far more important story of an idea's broader dissemination and reception. ${ }^{8}$ Even Schenker's theory of linear reduction is one that has been traced by several of our colleagues to multiple sources, suggesting again that a part of it was always in an unwritten - or, better yet, a multiply written-theoretical tradition.

As we scour the history of music theory, we can find many such subcurrents of "hidden" music theory. In recent years, a small group of scholars active in Munich have excavated what might be one of the most dramatic examples of such a vibrant teaching tradition in music theory. As this research is new and

7 One more example drawn from Rameau can be briefly recounted here. The règle de l'octave that Rameau attempts to analyse (twice) in his Traité de l'harmonie turns out to have been a commonplace mnemonic among music teachers since at least the middle of the seventeenth century for teaching the thoroughbass. Rameau may well have learned it from Campion, who wrote a whole treatise on the règle. But Campion himself credits it to one of his teachers who had long applied it in instructions of the thoroughbass. And, as I have shown elsewhere, it was a mnemonic that was found throughout Europe in a variety of forms and applications (Christensen 1992).

8 An idea of I have explored further in Christensen (1993, 189-90). 
not yet well known among music theorists, I would like to briefly report on it here. It is the case of Johannes Hollandrinus.

\section{HOLLANDRINUS AND THE SEARCH FOR AN ELUSIVE AUTHOR}

"Hollandrinus" is not a name well known to musicologists today. In fact, we know virtually nothing of the person. He seems to have lived somewhere in central Europe during the second half of the fourteenth century and was active as a teacher of chant theory. But not a single text has come down to us that we could attribute to his pen. Still, there is an extraordinary group of some thirty theory manuscripts stemming from central Europe and spanning the early fifteenth century until the second quarter of the sixteenth century that invoke his name (or variants of it) and seem to represent his teachings, at least in parts. Thanks to the dogged philological work of Michael Bernhard and Elżbieta WitkoskaZaremba (2010-), it is now possible to distinguish several layers within the Hollandrinus teaching tradition to a remarkable degree. Through a careful analysis of various topics, terminology, locutions, and mnemonic devices, they have first been able to reconstruct a "core" of teaching that belongs to the earliest texts of the Hollandrinus tradition (the loci Hollandrini). It is this core that seems to have received widespread dissemination and assimilation among music theorists active in large swaths of Southern Germany, Bohemia, Hungary, and Poland in the fifteenth century. But the reception was never simple and straightforward. In the process, much new material was interpolated, just as older parts of the "central" tradition were modified or discarded. This then represents a later stage of the tradition (loci auxiliaries). At a certain point, though, it becomes impossible — and ultimately besides the point-to disentangle any "original" text or teaching that we might attribute to the elusive Hollandrinus from these subsequent accretions; instead, we can view them together as a dynamic and ever-evolving "teaching tradition" that spanned a wide geographical area for over a century and a quarter.

The texts themselves suggest how the process might have worked. Most of these manuscripts are partial, unsystematic, and unpolished; they seem more to represent notes of teachings (reportiones) that were passed on orally. The hodgepodge nature of the extant manuscripts we have suggests a comparison to McLuhan's notion of a mobile "network" by which knowledge is seen as a fungible, dynamic complex that is conveyed and controlled by multiple local "agents." This would explain the many variants we find; a teacher (or student) evidently would add, rearrange, or substitute material within this teaching tradition. (Undoubtedly there was a good deal of misremembering, too.)

It was a tradition in which each teacher-each "agent"-participated and shaped the material; yet a thick thread of continuity was retained in the process of this transmission. We have endless examples of this phenomenon in later music theory: Rameau's fundamental bass, Riemannian functionality, and sonata-form theory are all obvious examples of a core thesis (or a thesis complex) that is adaptable and evolves over time and place. (Many years ago, we might have called such core arguments a "paradigm" on the basis of the scien- 
tific model of Thomas Kuhn, although I think now that was a terribly wrongheaded analogy, and one that has reinforced a number of pernicious associations regarding the "scientific" nature of music theory from which we are still weaning ourselves.)

In any event, the content of the loci Hollandrini, as we might expect, is many layered, with some of it traceable as far back as the eleventh century (borrowings from Johannes Cotto, Lambertus, and Johannes de Muris have all been identified). But much of the content in a manuscript is unique, suggesting some local traditions. The focus of all these texts is uniformly upon chant practice, with problems of modal classification and the fundamentals of "musica plana" the central concern. If one looks for any sign of the more "progressive" mensural or contrapuntal theory being taught in Italy, one will come away disappointed.

Still, this tradition has truly profound implications, and these offer a cautionary tale to historians of music theory. First, there is the obvious lesson that theoretical teachings were taking place throughout Europe in the fifteenth century, outside the more familiar Western centres. In addition to Paris, Padua, or Oxford, we must also remember Prague, Cracow, Leipzig, Budapest, and Breslau as places of music-theoretical activity—and no doubt many more.

Second, we are reminded that chant theory remained a dominating concern of most practising musicians throughout the fifteenth century (and well beyond for that matter). It is all too easy for us to be dazzled by the summits of polyphonic composition in the fifteenth and sixteenth centuries and forget that this was still a highly specialised-and professionalised—genre of music making. For most church musicians throughout pre-Reformation Europe, monophonic chant, not complex polyphony, either sacred or secular, remained the primary staple of their craft and musical world. And for many of these musicians, the pedagogy they continued to teach and learn in the midst of the most opulent polyphonic practice was one firmly rooted in medieval tradition. ${ }^{9}$

Finally—and most importantly for my present argument—-the Hollandrinus manuscripts remind us that music pedagogy and theoretical teachings should not be reconstructed only by relying upon a canon of fixed texts. We have in these manuscripts a glimpse (but by no means a clear representation) of a robust oral teaching tradition that must have existed for centuries across the whole of Europe. Indeed, this was surely more the norm in music pedagogy than the exception. The Hollandrinus tradition reminds us how music theory can be a dynamic, evolving process, a lively subject of oral pedagogy and practice, not just a static object ossified within a single, unchanging text. Each manuscript we have found in the Hollandrinus network is but one moment, one faint vestige, of a widespread and ever-evolving teaching tradition.

9 On the reception of medieval music theory in the Renaissance, see Mengozzi (2010). 


\section{PARTIMENTI AND THE INDUSTRIALISATION OF THOROUGHBASS PEDAGOGY}

If the examples of Boethius and Hollandrinus show us how fragile textual stability may be in premodern music theory, there is another example of music theory pedagogy from the eighteenth century that seems to pass textual codification altogether. This is the literature of "partimenti" manuscripts whose importance has been made known to us thanks largely to the industrious advocacy of Giorgio Sanguinetti, Rosa Cafiero, and especially Robert Gjerdingen. ${ }^{10}$ Partimenti, as we now know, are instructional basses (figured or unfigured) that a student learns to realise on a keyboard by playing some appropriate harmonisation with the right hand. ${ }^{11}$ In most cases, these exercises proceed in difficulty, from simple diatonic harmonisations of a bass line often following the "rule of the octave" to successively more challenging progressions involving chromaticism, modulation, and various kinds of textural elaboration. Advanced partimenti could even include contrapuntal genres such as the fugue and canon.

There are literally thousands of partimenti manuscripts scattered in archives around Europe today. (And no doubt many times that number of manuscripts are lost to us.) Towards the end of the eighteenth century, some of these partimenti began to be published in various collections. Together, this literature testifies to a once vital and robust pedagogical tradition that spanned virtually the whole of Europe from the late seventeenth century well into the middle of the nineteenth century.

As Sanguinetti (2012) has documented, the partimento tradition was cultivated most assiduously in the Neapolitan conservatories, where young children were drilled in the practice. Under the tutelage of a maestro, the student would play these exercises over and over and over, learning in the process idiomatic harmonies and figurations above the bass lines. At the same time, techniques of solfeggio were cultivated by which melodious upper voices were produced or harmonised. After many years of such practice, the successful student not only was fully proficient in the performance of a thoroughbass but also would have gained mastery in harmony, counterpoint, melody, all currently fashionable musical genres and styles-everything, in short, necessary to be a successful composer and music director. It is no wonder that the musicians who poured out from these Neapolitan "music factories" (as Gjerdingen has aptly put it) soon occupied most of the prestigious court positions around Europe throughout the eighteenth century, allowing them in turn to further propagate the partimento model of music pedagogy.

The point I wish to draw attention to here is how this was artisanal knowledge that was largely non-discursive and that bypassed traditional textual codification. Instead, the partimento represents a tradition of embodied knowl-

10 See Sanguinetti (2012). Robert Gjerdingen has a website in which dozens of partimento manuscripts have been transcribed and realised (Gjerdingen 2015). The website also has a number of helpful didactic features offering a history of the partimento, biographies of the major Italian pedagogues, and hints for the performance of the exercises.

11 See in particular the collection of essays in Christensen et al. (2010). 
edge in which the practical understanding of harmony and counterpoint was inculcated through emulation and endless repetition. It was literally "finger" knowledge. To the extent there was any articulated theoretical component to the partimenti exercise, it was one that would have been conveyed orally by a master.

It is true that a few manuscripts and publications do distil certain "rules" and precepts. (The exercises of Durante or Leo-the two greatest and most influential Neapolitan partimento teachers of the eighteenth century-both are typically ordered along a graded series of regole.) But these rules are all just about meaningless without the practical application required by keyboard realisations guided by a seasoned tutor. Consider, as one representative example, Durante's seventeenth rule: "When the partimento is tied, it takes the 2 nd and 4th above the tied note" (Durante 2015; Quando lega il partimento sopra la nota legata ci vuole $2 a$ e 4 a). This is a prescription to play a $4 / 2$ chord above the suspended bass note. Yet the varieties of possible fingerings and resolutions of this chord (never shown since these are all "unrealised" basses) are not explained by this rule. Clearly, the student would be dependent on a master hovering over his shoulder and helping him test out various possibilities. If the fourth were augmented, it would have a differing tonal implication than if the fourth were perfect. Likewise, if the second were chromaticised, the resulting chord would have differing tonal implications (and resolutions). So too would the scale degree upon which one finds the chord. The point is that partimento exercises were ideal laboratories for testing various kinds of interval inflections and contexts. Most critically, though, it was a skill that one could only master through repeated application on the keyboard.

This is not to say that there was never any attempt to codify this Neapolitan practice by theorists. Ironically, it was a German theorist who probably came closest to doing so: Johann Heinichen, in his mammoth thoroughbass treatise, Der General-Bass in der Composition of 1728. But this is not surprising when we learn that as a young musician Heinichen spent six years living and working in Venice (1710-16), earning some success as an opera composer before taking on the prestigious post of Kapellmeister in Dresden in 1717. More than anyone else, Heinichen attempted to capture the richness and complexity of the Italian partimento tradition that was otherwise learned only under the tutelage of a maestro. Yet the fact that Heinichen had to labour over almost a thousand pages (the majority of them occupied by musical examples) also suggests how formidable a task this was. The endlessly nuanced uses of dissonances-particularly in the newly fashionable "theatrical" style-required hundreds of examples and categories that surely would have taxed the patience of any user of his text. To learn the use of the four-two chord discussed in the Durante example, Heinichen would differentiate a quarta subsyncopata (tied or "gebundene") from a quarta irregolare, quarta transiens, quarta suavis, and so forth. All these dissonances had standard resolutions, to be sure. But in the more extravagant "theatrical" style that he learned in Venice, it was also possible to leap from a $4 / 2$ chord, "resolving" the suspended dissonance in another voice (a process he termed "verwechselung"), or indeed to begin the $4 / 2$ chord without 
any preparation at all (anticipatio transitus). Then again, the chord progressions can be varied through varieties of diminution or thickened in a "full-voiced" realisation.

It is this very richness and comprehensiveness that was the glory of partimenti pedagogy but also its eventual downfall. For anything so complex to master, so artisanal in nature, could not withstand the Enlightenment demand for simplification, systemisation, and rationalisation. These were just the qualities that Rameau's theory of harmony satisfied, and they assured the latter a rapid and enthusiastic acceptance over the course of the eighteenth century, particularly among thoroughbass pedagogues. For beyond its claims to intellectual or scientific pretence (which was immense), the basse fondamentale was a supremely efficient means of simplifying the learning of chords and their progression (if oversimplifying them). All those many species of fourth over which Heinichen agonised could now be reduced to a few fundamental prototypes (most easily as inversions of seventh chords). The partimento practice, as Ludwig Holtmeier $(2007,42)$ has aptly put it, "could raise scant opposition to the manifest logic of Rameau's principle of inversion." The basse fondamentale may have been a blunt instrument to bludgeon eighteenth-century harmonic practice within a systematic framework, but there was a clear pedagogical demand for something of its sort.

Of course Rameau's theory did not completely displace the partimento tradition. As we have noted, manuscripts of partimenti exercises continued to be copied well into the nineteenth century. And it was not just manuscripts. Thoroughbass methods influenced by the partimento tradition began to be published in ever-greater numbers during the eighteenth century (although none of them displayed the systematic pretensions of Heinichen). In Germany, this tradition often went by the name of "fundamenta." Clearly, though, the partimento and fundamenta traditions offered many musicians a more congenial type of embodied music theory that was not satisfied by the reading of Rameau's texts, however much the latter may have been dependent upon this practical tradition.

In the title of this essay, I have alluded to a canon of monumental texts that scholars have long used to reconstruct - and celebrate - the history of the discipline of music theory. And, lest I be accused of being disingenuous, let me quickly acknowledge that the Cambridge History of Western Music Theory that I edited in 2002 is filled with citations from such texts penned by authors who occupy the pantheon of Western music theory: Boethius, Guido, Muris, Zarlino, Rameau, Kirnberger, Fétis, Riemann, and Schenker. No, I do not suggest by my arguments that the writings of these authors do not constitute major landmarks in the history of music theory, still less that we should cease reading and learning from them. What I do hope we can do, though, is to interrogate them with a bit more critical acumen and curiosity. How exactly were these texts composed by their authors and for what purpose? Just how were these texts used by readers in their own day? And what else might there be "beyond" the written pages of these texts? In short, how might we go about trying to recapture the discipline 
of music theory as a true practica rather than just as a catechism of doctrines? In the four exempla I have presented in this paper, we have seen how music theory as a practice often overflows the frames of textual codification. The examples I have cited in this paper are testaments to how fragile texts ultimately are, how they are only a partial record of the real work of music theory.

This essay by no means constitutes an adequate analysis-let alone a description-of this elusive work. But I am convinced that there is something out there beyond the printed text that enriches and vitalises the work we do as music theorists. Maybe that something can be reanimated from the margins of medieval manuscripts where questioning glosses and comments are scribbled by exasperated scribes; maybe it is to be heard in a small cloister in Krakow where a monk in the fifteenth century struggles to teach his young singers the rudiments of chant classification and theoretical lore through memorised stories and verses; maybe it is in the tired fingers of an orphaned keyboardist in a Neapolitan conservatory practising endless figured-bass patterns under the severe tutelage of his master. In short, maybe it is outside the pages of elite texts by which we have usually thought to constitute and represent the discipline of music theory. It is perhaps a less heroic picture than we might have imagined, in which theorists - like Rodin's famous statue of le Penseur - contemplate in Platonic solitude the mysterious wonders of harmonia. But it nonetheless does represent music theorists in a more realistic light, as real human beings working away in their scriptorium, cloister, or practice room. Ultimately, it allows us to see music theory as a living, engaging, and ultimately human activity.

\section{REFERENCES}

Balensuela, C. Matthew. 2001. "Anonymous Theoretical Writings." In The New Grove Dictionary of Music and Musicians, edited by Stanley Sadie, 2nd ed., 29 vols., 1:693-707. London: Macmillan.

Bernhard, Michael. 199ob. "Das musikalische Fachschrifttum im lateinischen Mittelalter." In Zaminer 1990, 37-103.

——_. 1990c. "Glosses on Boethius' De institutione musica." In Music Theory and Its Sources: Antiquity and the Middle Ages, edited by André Barbera, 136-49. Notre Dame, IN: University of Notre Dame Press.

Bernhard, Michael, and Calvin M. Bower, eds. 1993-2011. Glossa maior in institutionem musicam Boethii. 4 vols. Munich: Verlag der Bayerischen Akademie der Wissenschaften.

Bernhard, Michael, and Elżbieta WitkowskaZaremba. 2010-. Traditio Iohannis Hollandrini. 8 vols. Munich: Verlag der Bayerischen Akademie der Wissenschaft. Boethius, Anicius Manlius. 1989.
Fundamentals of Music. Translated by Calvin M. Bower. Edited by Claude V. Palisca. Music Theory Translation Series. New Haven, CT: Yale University Press. Translation of De institutione musica.

Bower, Calvin. 1988. “Boethius' De institutione music: A Handlist of Manuscripts." Scriptorium 42: 205-51.

—_- 1989. Introduction to Boethius 1989, xix-xliv.

Christensen, Thomas. 1992. "The Règle de l'octave in Thorough-Bass Theory and Practice." Acta Musicologica 64 (2): 91-117.

—— 1993. "Music Theory and Its Histories." In Music Theory and the Exploration of the Past, edited by Christopher Hatch and David W. Bernstein, 9-39. Chicago: University of Chicago Press. - 1996. "Johann Nikolaus Bach als Musiktheoretiker." Bach-Jahrbuch 82: 93-100.

- - 2002. Introduction to The Cambridge History of Western Music Theory, edited by 


\section{Thomas Christensen}

Thomas Christensen, 1-23. Cambridge: Cambridge University Press.

- 2011. "Fragile Texts, Hidden Theory."

Musica Humana 3 (2): 177-208.

Christensen, Thomas, Robert Gjerdingen,

Giorgio Sanguinetti, and Rudolf Lutz.

2010. Partimento and Continuo Playing

in Theory and in Practice. Edited by Dirk

Moelants and Kathleen Snyers. Collected

Writings of the Orpheus Institute.

Leuven: Leuven University Press.

Durante, Francesco. 2015. “Regole: 17.” Monuments of Partimenti. Accessed 13 May. http://faculty-web. at.northwestern.edu/music/gjerdingen/ partimenti/collections/Durante/ regole/25DurReg/25DurReg.htm.

Gjerdingen, Robert O., ed. 2015. Monuments of Partimenti. Accessed 13 May. http:// faculty-web.at.northwestern.edu/music/ gjerdingen/partimenti/index.htm.

Goehr, Lydia. (1992) 2007. The Imaginary Museum of Musical Works: An Essay in the Philosophy of Music. Rev. ed. Oxford: Oxford University Press. 1st ed. published 1992 (Oxford: Oxford University Press).

Holtmeier, Ludwig. 2007. "Heinichen, Rameau, and the Italian Thoroughbass Tradition: Concepts of Tonality and Chord in the Rule of the Octave." Journal of Music Theory 51 (1): 5-49.

Mengozzi, Stefano. 2010. The Renaissance
Reform of Medieval Music Theory: Guido of Arezzo between Myth and History. Cambridge: Cambridge University Press. Meyer, Christian. 2001. Les Traités de musique. Typologie des sources du Moyen Age occidental 85. Turnhout, Belgium: Brepols.

Niedt, Friederich Erhardt. 1710. Musicalische Handleitung, oder, Gründlicher Unterricht. Hamburg: B. Schiller.

Rehding, Alex. 2009. Music and Monumentality: Commemoration and Wonderment in Nineteenth-Century Germany. New York: Oxford University Press.

Sanguinetti, Giorgio. 2012. The Art of Partimento: History, Theory, and Practice. New York: Oxford University Press.

Schrade, Leo. 1947. "Music in the Philosophy of Boethius." Musical Quarterly 33 (2): 188-200.

Schröter, Christoph Gottlieb. 1772. Deutliche Anweisung zum General-Bass in beständiger veränderung des uns angebohrnen harmonischen dreyklanges. Halberstadt: Johann Heinrich Gross.

Zaminer, Frieder, ed. 1990. Geschichte der Musiktheorie 3: Rezeption des antiken Fachs im Mittelalter. Darmstadt: Wissenschaftliche Buchgellschaft.

Zumthor, Paul. 1972. Essai de poétique médiévale. Paris: Éditions du seuil. 


\title{
Chapter Eleven
}

\section{Testing Respect(fully)}

\section{An Interview with Frederic Rzewski}

\author{
[Conservatoire Royal de Musique, Liège]
}

[This interview was conducted by Luk Vaes on Tuesday 27 March 2012 at the Orpheus Institute, as part of the International Orpheus Academy for Music and Theory. This transcript is based on an audio recording of the interview; however, silent adjustments have been made to aid readability, and some material has been omitted.

As part of the Academy, Frederic Rzewski was invited to perform a piano recital $^{1}$ and to participate in an interview with the aim of exploring the Academy's theme, "Experimentation versus Interpretation," from his perspective as a performer already active at the time of the experimental avantgarde and as a composer linked to that movement. Rzewski's recital was constructed as an experimental programme of solo piano music, performed as one long work with neither pauses between pieces nor a published running order. Historically experimental music (e.g., by Cage and Takahashi) was juxtaposed with classical repertoire for which Rzewski has developed an experimental performance practice (e.g., by Schumann), and both were interspersed with his own works. The day after the recital Rzewski returned to the stage to explore the theme of the Academy, his relevant practice as a pianist and a composer, and his historical insights.]

ORCiм: I would like to start by referring back to yesterday's programme a little bit, inspired by the slide shown by Thomas Christensen yesterday, which featured a quotation by Bernard Suits about non-traditional players ${ }^{2}$ and connected it to experimentation. This would be one notion that I want to explore in terms of what experimentation could be in your case. Your programme 3 was one long piece, which ostentatiously omitted any inter-

\footnotetext{
DOI http://dx.doi.org/10.11116/9789461661883.ch11

1 For the video recording of excerpts of this concert, go to http://www.orpheusinstituut.be/en/ experimental-affinities-in-music-repository

2 In his presentation, Thomas Christensen discussed Bernard Suits's The Grasshopper: Games, Life and Utopia (2005), in which Suits itemises four kinds of "non-traditional" players in games: "triflers," who seek unorthodox goals-for example, not winning; "cheats," who break the rules; "spoilsports," who refuse to play; and "tricksters," who undertake deceptive if not "illegal" practices.

3 Pieces performed included Rzewski's Etude (composed 2010) and Nano Sonata No. 8 (composed 2008), Felix Mendelssohn's Lieder ohne Worte op. $3^{8}$, nos. 5 and 6 (composed 1836-37), Robert Schumann's Nov eletten op. 21, no. 2 (composed 1838), Abraham Goldfaden's Rozhinkes mit mandlen [Raisins and Almonds] in an arrangement by Yuji Takahashi (arranged 2011), and excerpts from Christian Wolff's Small Preludes (composed 2010) and John Cage's Etudes Australes (composed 1974-75).
} 
mission or even pauses in between pieces. It's a mix of unknown and known, both in the classical and in the new music repertoire. When did you start programming like this? It's almost a trademark of yours, but how did you start with this kind of composed programme?

FREDERIC RZEWSKI: I haven't been doing this very long, in fact this is just an idea that struck me quite recently. I've done similar programmes now only three or four times, recently. It's something that ... I don't know why I am doing this. It is a pragmatic response to certain occasions which present themselves. People often ask me to play Beethoven, for example. In fact you did, I thinkyou suggested that for this occasion I should do the "Hammerklavier" with improvisation.

Exactly, because I remember a programme like this, where you played the "Hammerklavier" and stopped between each of the movements to play one of your own shorter works.

That was twenty years ago.

Yes. So that is another example of how you non-traditionally approach both the programme and a piece like the "Hammerklavier." I mean a lot of traditional players would say, "You cannot stop and do something else in between two movements of such an iconic piece by Beethoven," because it was composed to be played as one, supposedly.

Well, on the other hand, I am not an expert on the subject. But I seem to remember that there are numerous instances of nineteenth-century virtuosi like [Hans von] Bülow, who would combine one movement of one Beethoven sonata with another movement of another. And in fact as recently as 1960 I remember Gordon Mumma told me about a concert that he attended at Carnegie Hall in New York of the pianist Wilhelm Kempff, which was advertised simply as "Wilhelm Kempff Plays Beethoven." And what he did was to play seven sonatas of Beethoven continuously with improvised transitions.

\section{Kempff did that?}

So this is part of the grand classical tradition, which has survived up until relatively recently. And I think it is only in the last few decades that you have a different approach to this tradition, represented by people like [Maurizio] Pollini or [Alfred] Brendel, which is much more, how should I put it ... stark is not the word ... rigorous or in some ways puritanical—focussing on perfectly executed pitches and so on and so forth.

And complete works. 
Yes. The tradition is full of these swings back and forth, I think, from one antipode to another. There is no one tradition, I think. It's complex and it's full of deviations.

But you could...

... go back to Beethoven himself, I mean he would perform these totally unexpected, half-hour improvisations, with the musicians waiting impatiently for him to finish. The man himself is a bag of contradictions.

So you could see yourself not as a non-traditional player but as one who...

... a traditional. Just as Heinz-Klaus Metzger said-we were just talking, me and [Hermann] Danuser, about our mutual friend Heinz-Klaus Metzger, who insisted that John Cage was a totally traditional composer in the tradition of Beethoven. And it is exactly what he meant, I think.

I think we will end up discussing Beethoven as the first experimental composer, perhaps.

Well, could be. Could be.

Continuing on from that Bernard Suits quotation, and talking about "triflers" and "cheats" and "spoilsports," what is the reception of programmes like this when you present them in venues that are normally quite polarised, such as either completely new music festivals or completely classical stages? There is the US versus the EU, etc. What is your experience of that?

Well, surprisingly positive-considering that I am very often trying to provoke reactions from people who would otherwise not express themselves. So I am quite surprised to find that actually people seem to like it.

Did you purposely try to provoke a non-positive reaction, then?

No. No, but I was taking a certain risk. Of course I didn't really know what kind of an audience this would be. I had a somewhat vague idea, but ... I was taking a certain risk, because, for example, the Schumann piece I have never played for an audience before.

And you said afterwards that this was an experiment, it was a test.

Well. In a sense it was. The reason I included it was because it occurred to me that one form of experimentation, in this case for instance, would be to perform the music exactly as the composer wrote it. Inherited from this oral tradition of performance of classical music, again, if you try to perform exactly what Beethoven says, for example, people will tell you "well, you can't do that." For example, something that Beethoven does with great consistency, a crescendo 
to forte and then subito piano - the "Appassionata" is full of that-if you actually play that people will say, "You can't do that. You can't have such sharp contrasts." But, on the other hand, that seems to be what it's all about. Or, if you take the "Moonlight" Sonata, the first movement, he says it's "sonata quasi una fantasia," which in a way already tells you that it's like a parody of the Mozart D-Minor Fantasy. [sings the opening triplets of the Mozart D-Minor Fantasy] And you try to play it at a similar tempo ... [laughs] Right? [moves to the piano]

Please go ahead, provoke us.

Well. We all know that if you try to play it at that kind of Mozartian tempo ... [plays the opening of Beethoven's Sonata No. 14 ("Moonlight") with the accompaniment eighth notes in the same tempo as those of the Mozart Fantasy] it's like Mozart. But if you try to play that - you can't play that. [laughs]

You have carried out this experiment as well?

Well yes. But not frequently. People sometimes ask me to play Beethoven, for some reason. I say, "Well OK. I can do it, if you really want it. But I have to warn you, you are not going to like it." "Oh, yes, yes of course we will." And then I do it and they say, "You can't do that. You can't improvise in the middle of Beethoven's sonata. You can do that at parties, but you cannot do it on the stage."

Or at a conference.

Or whatever, yes.

Is that what you meant yesterday, when after the concert you asked a few people, "well, I want some criticism, I want ...”?

Yes, because I am not absolutely sure of what I am doing. I am not an expert on Schumann, for instance, by any means. And I am quite positive that there are many classical pianists around who would totally disagree with my approach. For instance, in this case, in this particular piece of Schumann, the number two of the Novelletten, Schumann gives you a ... he says, äusserst rasch, extremely fast. And he gives you the metronome indication of 92 to the half note. So I went and did some research, and I must have listened to at least fifty different versions of this piece by well-known pianists and lesser-known ones. I could not find a single one where this tempo indication was respected. Most pianists seem to play it at about 80 . Which is pretty fast, but it's not extremely fast. So I decided that an experimental approach to this music in this case would be to play it at the tempo that the composer says to play it and see what happens. [laughs] You see. Because I am quite sure that many people would say, "Well it's too fast." In fact, Professor Danuser pointed out last night that it may be ... there may be a question of the difference between modern pianos and the instruments of 150 
years ago, which would have been less resonant and probably easier to play, so that a faster tempo would be more appropriate to an older instrument. And this is probably true. On the other hand, I don't see any reason why it should not work on a modern instrument as well.

And even if it didn't work on a modern instrument, and that was the reason for those fifty pianists to take it at a slower tempo, playing something slower than marked has an effect on the composition just as much.

Oh yes, it does. It absolutely does. In this case it is important to play it fast enough so that the metrical unit is the half note, which is what Schumann says. If you play it slower, then the metrical unit becomes the quarter note.

Experiments are normally assessed in terms of success and failure. How do you assess its musical validity having now played it at the tempo of Schumann? Is there a difference that you notice compared with the performances of those fifty pianists?

No, I would say the jury is still out. Because I still can't play it! [laughs] As I say, I played it last night for the first time for an audience. And maybe I am a good faker and people didn't notice all of the mistakes, but it was really not a good performance, [laughs] I have to admit.

Well, experiments are often carried out in stages, to allow for refining the set-up or the protocols. What would you do in a further programme with the Schumann? Would you, I don't know, practise more, or would you take a slower tempo nonetheless? Would you do something else?

It's possible.

But you have no ideas yet about how to approach it?

Well, I have lots of ideas. But I try not to let a single idea dominate. On the contrary, my approach to performing is similar to my approach to composition. I try not to think about it too much. I just do it. This may be inappropriate in a room full of theorists, but I think that the important thing in art is not to understand what you are doing. The important thing is to do it. And very often the attempt to analyse or understand what one is doing interferes with one's ability to do it. When you are crossing a crowded street, you don't think about all the possible ways of doing it, you just do it—otherwise you may end up dead. So, in performing arts in particular, it's a similar situation.

There's an aspect of risk in experimentation. And it connects to improvisation, which you talked about in that sense, yesterday, over a beer - that you don't think while you're doing it, you don't anticipate. Now I have a couple of questions about yesterday, when you improvised in several pieces. I have heard you improvise in pieces that needed it, like Beethoven concertos, where there is a cadenza and you improvise the cadenza. I've heard you do this 
in sonatas where there is a fermata. But traditionally people don't consider sonatas to be the place to extemporise within the structure. I've heard you do this in Viennese Classical pieces, where there are no fermatas, and I've now heard you do it in Romantic repertoire, in Mendelssohn and Schumann. My first question would be, would you also do this in twentieth-century pieces? Outside your own composed pieces like El pueblo unido, ${ }_{4}$ in which there are moments where you as a composer ask the pianist to improvise, would you do this in compositions where there is no indication?

Absolutely. In several of my own pieces last night there were short improvisations. And there is a tradition of improvising in written music which is still very much alive. One of the pieces that I might have played last night but didn't was a piece by the composer Steve Lacy, who died a few years ago and was best known as a jazz musician but was also a prolific composer. And certainly improvisation was a structural element in his music, which was written down-totally written down, totally determined-but at the same time required opening up the text to an improvisation. It's part of the language.

Would you have improvised in yesterday's concert in the [Yuji] Takahashi piece or the [Christian] Wolff piece?

No.

On what would that decision depend? On the moment? Or would you actually beforehand think, "At this point in the piece I will do something," and not in the other piece?

Well. I know the composers and their intentions well enough to know what they expect and what they do not expect. There are certainly many compositions by Christian Wolff where improvisation is part of the text, and similarly with Takahashi. They are both improvising composers. But these particular pieces, no. And the same goes for my own work. There are pieces of mine where I may introduce an improvisation, and others not.

Where you know you would never improvise.

Well, yes.

So how does that compare with the Schumann or Mendelssohn? Do you improvise there because we asked you for such a programme?

That might be part of it. But it might also be because I am having trouble turning the page! [audience laughs]

4 Rzewski's The People United Will Never Be Defeated! (composed 1975), thirty-six variations on the song “ ¡El pueblo unido jamás será vencido!” by Sergio Ortega and Quilapayún. 
I was going to ask about the difference between improvising consciously to improvise and improvising to save yourself from a tricky situation. I mean it's handy if a pianist can improvise when he has a blackout and doesn't want to let people know that he has to stop and search for the score. You can just make it look like, well...

That reminds me of a concert I did-a memorable occasion — at the University of Maryland in the seventies, where I played, among other things, a piece by Tom Johnson, a composer now living in Paris. The concert was delayed for two hours because there had been a bomb threat. So the entire building had to be searched. Miraculously enough, the audience hung around for that period, and we all went in, two hours late, and the concert started. It went along normally until suddenly all the lights went out. And my first thought was-I was in the middle of Tom Johnson's piece-that after this bomb scare, you know, this might create an incident, and I better just pretend that this is part of the piece. So I went on playing this piece in the style of Tom Johnson in the total darkness. After about a minute the lights came on again, and everybody assumed this was part of the score. [audience laughs] So you see, it is useful, I think. [audience laughs]

What about the audience reception of your improvisational practices within pieces? Do you take this as an experiment to see how people would appreciate this?

Well there are venues where improvisation is expected. In fact there are venues where if you bring a piece of paper onstage, you are regarded as some kind of spy. The free improvisation "church," which is what it has become by now, the pope of which used to be Derek Bailey. These people are still around. For example there used to be this festival in Switzerland, Taktlos. This pianist Irène Schweizer was in charge of that. And I remember, I played there once. I came on to the stage with some music on paper and it was like I was peeing on the stage. [audience laughs] On the other hand, you have the classical audiences where if you dare to do something that is not in the score, you know, you're put on trial. So ... it can go pretty far.

Wasn't there a moment when you wanted to play Beethoven's Fourth Concerto with your own improvised cadenzas and the conductor objected to that?

That's right. Yes, yes. But normally we didn't even get that far. The conductor objected to the way I played the written music. [audience laughs] For instance, Beethoven would say "ritardando." So I would make a ritardando, assuming that the conductor would follow. But as we know the orchestras don't have time to rehearse today. So they can't do anything, except proceed in a mechanical way from beginning to end. Basically, the best you can expect these days is a very cursory reading of the text. And that counts as a rehearsal. Because they need the rehearsal time to do the "Eroica" Symphony or something like that, which they all know by heart. But that's the way it goes. 
You say, you didn't get that far? You mean the concert didn't even happen because you have such...

No. I was fired. [audience laughs]

Oh, you were fired.

Yes.

But you stood ground, because you...

I was also paid. Which I began to think was an interesting deal. [much audience laughter] I should make a specialty of this! [laughs]

I see, that's how you started this. OK. I had wondered about that. I mean it would never have been a problem here to mix contemporary with classical music. But in the contemporary music scene it might look suspicious if you start improvising in Mendelssohn-even to bring a piece like that. And I was wondering about the improvisational scene, where you have been active. Do you also mix composed music there with the improvising that you do with your friends like Steve Lacy and [Anthony] Braxton?

Oh, absolutely. Of course. Certainly. Both of these people were-and still are, of course, in the case of Braxton-serious composers. Although the conventions of the so-called contemporary music scene would make it difficult for such people to be recognised as serious. But for that matter, even John Cage today ... even though lip service is paid to his reputation in contemporary music. There everybody is, celebrating his hundredth birthday; but as we were just discussing, in the midst of all of these festivals and so forth about John Cage there is very little serious attention being paid to his important work. He is still not completely accepted as a composer.

We'll get to that tradition in just a minute. I would like to finish discussing the programme by talking about your interpretation and how you interpret, methodologically speaking. Because I am very happy that you brought it up yesterday, and yesterday night in the cafe, and now, about faking.

\section{Faking?}

About faking. When, I mean it's a taboo, but most new music performers know this. When a performer receives the score, even if it's impossible to perfect the piece, it's better to make something of it than just to cancel the concert. And often, in all our experiences, composers are just happy that you made something of it. Even though you know how many notes, how many structures, how much of the piece you weren't able to realise. And then I am thinking about faking versus improvisation, faking versus this type of experimentation with respect for the score and with what's possible. So for you, where is the interpretation? 
Is it at home? Do you still consciously experiment, like with the Schumann? Do you do this with new music? Or...

When I grew up, when I was a kid, I remember I was told by my teacher that interpretation was something that one did with the score which was not written down. It was also called expression, and it mainly had to do with dynamics-soft and loud, but also with rhythm. This is something that every student of classical music knows about, and all it is really is improvisation. Of course improvisation exists in classical music. It's called interpretation. It's improvising with a text. And in fact I am so deeply rooted in this. It is one reason why I decided a long time ago that I would no longer try to memorise classical music, which I was told that you had to do. And then I decided, “No, I can't do this. Because if I memorise a text, say of Beethoven or something, it means that I do it over and over again the same way." I don't want to do this. I want to play the music the way I feel it in the moment. And that might be quite different on Thursday from what it was on Wednesday. Yet both of these interpretations might be equally valid. So what I find is that I am much freer with the music if I have it in front of me, where I can see it. I don't have to keep it in my head. I don't even have to think about it. I don't even have to be able to read it. It can be vastly reduced, so I can't really read it. But as long as I see the profile of the score in front of me, I can improvise on it. I can do all kinds of things on it, which I can't do if I don't have that.

Nevertheless, amazing a sight-reader as you are, there are parameters that you improvise with on the spot but there are also things that you seem to prepare, like the Schumann tempo. That's not something you decide on the spot-you did some research, you listened to other recordings. You must have experimented at home with where you could bring this, whether it even would work. I mean if fifty pianists can't play it you would probably, I imagine, have had a moment where you wanted to test if...

Yes. It was an intellectual decision. Yes, of course. And I am not sure that it is correct. It is an experiment. That's why I am interested in getting some feedback about it. It may be that Professor Danuser's theory is correct-that in fact this tempo is too fast for a modern piano. If that is the case, I would like to know about it.

Would you go as far as making a recording or listening to the recording afterwards to determine for yourself, without the feedback of your audience, as to whether an experiment was successful?

Well. I don't really need to do that. In fact, recordings very often deliver false information about the past. Recordings are not necessarily reliable evidence. My own impressions are more reliable.

So you do have those. You don't have to rely solely on what the audience gives as feedback. What did you think yourself of the Schumann and that tempo? 
Well, I'm not sure. For one thing, when one is playing on the stage one doesn't really hear everything that one is doing. You certainly don't hear what the audience hears. You have barriers between you and the sound: you're sitting here, you have this instrument in front of you, and the sound is coming out over there and going over there. So very often it's quite different. But of course I have some idea.

And do you have any specific details about that? For example, is your impression, that when you play it with the half note at 92 you can do different things as a performer? Like make longer lines, bigger tensions, or...?

Yes, well. One I think important difference between a faster tempo and a slower tempo is that it becomes impossible at a faster tempo to play in the manner of Pollini or Brendel. It's impossible to distinguish clearly between one sixteenth note and the next. The sound necessarily becomes blurred and it becomes a colouristic effect. So that in a strange way it sounds more like [Karlheinz] Stockhausen than like classical music. I don't know whether this is what Schumann really imagined, but I have some ideas about it. And I have become very interested in the work of this composer in recent years, because the deeper I get into it, it seems to me that everything that I am trying to do Schumann did better. And I am trying to figure out why. One thing that fascinates me in this composer is his notion of inner voices. As you know there are a number of his compositions where he has a third voice, sometimes on an independent system but not always. Very often he specifies which notes have to be played with the left hand and which notes have to be played with the right hand. As this disposition does not correspond to the easiest way of playing the text, most pianists would tend to ignore those instructions and play what seems to fall most naturally or easily into the fingers. Whereas this seems to me a misinterpretation of what Schumann is trying do. What he is really trying to do in these cases is to bring out this third inner voice, which I think is a kind of dialogue between the two thumbs, usually. So you have one voice, another voice, and then this third voice in the middle. Which is this ... these two thumbs. It makes me think of what every adolescent child today is a virtuoso at - making text messages. My fifteen-year-old daughter can even do it with one hand. It is an amazing technique, which I am totally unable to ... [laughs]

Well I have questions about your experiences with electronic music and today's DIY. But before I close off this little chapter, I have two more questions about that. What are your expectations, as a composer, of musicians playing your music and doing the stuff that you do in other scores - faking, as well as improvisation and other types of experimentation?

Well...

Do you give them great freedom? How do you feel when they play your music with such attitude? Do they...? 
Yes. I try to write in such a way, that ... bad piano players don't go near it ... and that is ... it's not easy to explain. I think Chopin does that. You know, most of Chopin's piano music is not so difficult to play as one would think. It's virtuoso music, and virtuoso music is usually easy, but he often has one page where the music is genuinely difficult-like the next to the last page of the fourth Ballade, which [Arthur] Rubinstein talks about. When he did the entrance exam of the conservatory of Warsaw, they gave him that piece to play, thinking that he would screw it up, which he did, but he relates how there are certain things that happen in music that cannot be recorded. For example, he said he completely messed this piece up. But, at the end of the performance, he said, "I threw up my hands like this," and the audience rose to its feet and they had to let him in. 5 [audience laughs]

\section{A historical example of faking.}

Well, faking is very important. We were talking about it last night with regard to these music festivals in the sixties where we had to play ... well, I had to play... I guess you weren't around then...

Very young.

... pieces by all kinds of composers that should never have been written. And one knew very well that these pieces would be played once and then that was it. So, first of all, it wasn't worth practising them. Secondly, if one faked it, then the results were usually better than what was written by the composer.

You realise that not everybody here is a theorist. Some are composers. [audience laughs]

Well ... [hesitates] I think it's useful to know it! [everybody laughs]

You are a composer yourself, so you have a right to speak. But you made it easy for me to go on to another type of experimentation: the historical movement that was called "experimental music," with Cage in the middle. I was going to ask you about faking or other ways of experimenting, like improvisation, in that historical experimental repertoire. But first something general about you and that historical period or historical movement, you know, with Cage in the middle. [Michael] Nyman extended it to [Morton] Feldman and Wolff and [Robert] Ashley; ${ }^{6}$ English musicologist [David] Nicholls talked about the American experimental tradition; ; and then [Cornelius] Cardew was included as well. Do you see yourself consciously as part of that tradition? I know you have strong opinions about what is experimental music and what is not.

5 Rzewski may be thinking of incidents recounted by Rubinstein in My Young Years (1973, 40, 134), though misremembering certain details.

6 See Nyman (1999).

7 See Nicholls (1990). 
Well. I object rather to the term itself. I believe the first person to use this term was John Cage in an article he wrote about 1948 or something like that, in which he speaks about experimental music. ${ }^{8}$ And then this term gradually caught on. The trouble is that this music is not genuinely experimental. And it's used furthermore in a very vague way, which doesn't really tell you anything. At the time-in defence of that mindset, which predominated, that prevailed at that time-there was a tendency to equate avant-garde music with science. The composer presented himself to the audience, to the public, in the mask of the scientist. Wearing a white coat of a laboratory technician, something like this picture we saw this morning. The jargon of theory was borrowed from science, one spoke about parameters, and articles were written in which music was treated as though it were some kind of science.

With diagrams and theories and...

Yes. Fortunately this equation of these two incompatible fields has largely vanished. So in a way Cage could be pardoned for using that term. But unfortunately people still continue to refer to this tradition of "experimental music." I am not sure there is such a tradition. But yes, the people whose names you've mentioned were all colleagues and friends and of course I feel very much a part of what they were doing and talking about.

Would you have extended the same kind of freedom as a performer to works by these composers? For example, you didn't improvise in the Cage piece, yesterday.

No!

But I don't imagine that you consider Cage to be one of those composers who wrote pieces that you've played that shouldn't have been written?

No, no. But I should qualify that. What you are saying is that I did not improvise the notes. But if you know this score, you know that the only thing that is written are the notes and their distribution in space. Nothing is said about dynamics, phrasing, pedalling, any of these things. They are up for grabs. So yes, improvisation is very much a part of any performance of this piece. Even if you choose, as Grete Sultan did-she was the first person to perform this music [Cage's Etudes Australes ${ }^{9}$ ], the dedicatee-even if you choose to play everything flat, expressionless, and all mezzo forte, this is also a choice. This is not something that the score tells you to do. You can also play it in such a way that your performance is totally different from someone else's. In fact, Steven Drury and I played the entire Etudes Australes, all thirty-two of them, in Paris last yearalternating - and our two readings of this text are as different as night and day.

8 Cage employed the term frequently from 1939 and wrote about experimental music in a number of articles during this period (in particular, Cage [1940] 1961, [1955] 1961, [1957] 1961, [1959] 1961). On the history and context of Cage's use of the term, see Brooks (2012).

9 Cage's Etudes Australes (composed 1974-75) for piano. 
But this is I think an attribute of good music-and Beethoven was a master of this-that it is written very precisely but at the same time in such a way that it is open to a wide variety of different interpretations, all of which can be equally valid. And of course there are many, many examples of that. There are hundreds of ways in which you can play [plays opening of the first movement of Beethoven's Sonata No. 21 ("Waldstein")] just that.

You gave us one. Can you give us two?

No. No, I don't want to get into it. I prefer to leave it to the imagination. But... I mean, it's just an example of what I am talking about. It's a well-known icon, this opening. There are many others. And I don't want to get into that. But Beethoven was certainly very aware of that - he fussed over his notation-and so he was clearly very aware of the tiny differences between one way of writing something and another. And he managed to find ways of writing things that are both precise and open at the same time.

I find it interesting to go back to the experimental tradition, and to Cage. Maybe there is no tradition yet, just a few different ways of playing these pieces. Yvar Mikhashoff played it all romantically, even making phrases in the Etudes Australes, and then [David] Tudor was much more methodical, precise, and perhaps even scientific in a way. But Cage sometimes played a dubious role in that potential discussion himself. I remember that after a concert of the Concert for Piano and Orchestra (composed 1957-58) his critique of the pianist was that it was too much like in the score. There is one blank page and the rest are pages with graphic notations. He said, "We'll just play it more like a nineteenth-century concerto where the orchestra has more stuff to do on its own, and you should insert many more blank pages at certain points." Which is not what was in the score. So he seemed to have fluctuated himself.

Well he was certainly inconsistent. He in general did not like the way I played these études. He thought that I put too much of myself into them. He preferred a kind of neutral interpretation, which I take seriously. But at the same time it doesn't prevent me from doing whatever I damn please.

That's very interesting because, as you are a composer, you should be able to sympathise very easily with a composer saying, "I don't like the way you play my piece." But still you claim your rights as a performer to do something with the score, whether or not he is still alive to criticise you.

Well, I try not to change the score. If I am in the position of having to play a piece by another composer I may introduce some elements of freedom into it, but I do not change the text. Again, with Professor Danuser, we were talking about Cage's notational peculiarities. And I maintain the view that if John Cage's music has been wrongly interpreted and wrongly understood over the years and still is, it was his own fault. Because he employed notation in such a way that it became an esoteric thing. It was a kind of secret language, in order 
to understand which it was necessary to have access to the inner circle in which the oral tradition of how his music was to be understood could be ... and I had access to this inner circle-but most people don't. Most people reading a score of John Cage might have the impression, perfectly justifiably, that anything goes. And this was not the case-despite his reputation. Virgil Thomson called him a preacher, ${ }^{10}$ and in fact Cage had the most rigorous ideas of what was acceptable and what was not acceptable.

He even had outbursts of temper when people approached his scores with that attitude, that you can do anything - he really disliked it.

Absolutely. So he was a walking bag of contradictions, yes.

Yesterday you told me something interesting, about how you approach scores with certain freedom, but not all aspects. And you told me that you rewrote Stockhausen's [Klavierstück] No. 10 (composed 1954-55/1961), because the notation wasn't up to your expectations of what an efficient notation would have been. It seems like a lot of work to rewrite a piece like that.

I didn't rewrite the piece. I rewrote the rhythms. The rhythms are over the score, and they are simply durations which have no periodic metre.

How did he like that? Because you worked with him, you must have discussed this.

No, I don't think we did discuss it. I just did it. I don't think I asked him about it at all, I just did it. And oh, he liked the performance very much, yes.

He didn't notice that you had approached it differently?

No, I don't think so. No.

I would like to move on to technology. I have two more little chapters: technology and politics. I think I would like to close with politics-you like to talk about that. But first I would like to go back to something that is not discussed much and that you were an influential part in. That was Musica Elettronica Viva. I don't know how to translate it really. Did you mean "live electronic music on a stage" or "long live electronic music"? Is it a political statement? [audience laughs]

No, no. I think we were very close to the Living Theatre ${ }^{11}$ at the time.

In Rome?

Yes. So I think it's partly a reference to that.

10 See, for example, Thomson and Dickinson ([1987] 2006, 117-18).

11 An experimental theatre company founded in New York in 1947, on which see Tytell (1995). 
Because this type of collective music making on stage is often associated with experimental music. Not only because of the people that were involved but also because the way you treated electronics on the stage was much like how Cage and Tudor worked in the later years. But I've had some problem imagining you with live electronics. How did that go? I mean you didn't solder circuit boards...

I certainly did!

Oh, I'm sorry. I'm very happy to hear that! I just didn't know. Because the way you comment on ...

And, talking about self-inflicted wounds, [laughs] I came very close to electrocuting myself on a number of occasions! [everybody laughs]

So what were these concerts like? They are very famous but there is not much material. ${ }^{12}$ What was really happening there on stage with this group?

Well, I beg your pardon. What was really happening was anything.

Was it improvisation? Did you compose for this? Was it a fixed group?

We began by performing written pieces. We did many written pieces-for example, some of John Cage's early pieces, where you play records and mix records and radios and things like that. We did a number of performance pieces which were half written out, and then we got into free improvisation as time went along. It was simply part of the language of the mid and late sixties, which we explored. And then we got into audience participation. We had a piece called Sound Pool where people were invited to bring sounds and throw them into the pool. We did that maybe in about fifty performances in various parts of Europe, some of which were quite memorable.

What was your place in that group as a pianist?

At that time I mostly did not play the piano. I was playing mostly a piece of glass with various kinds of contact microphones and amplified junk, that kind of thing.

And was your attitude towards the scores-when you played from scores- the same as what you described today about playing the piano? As a performer did you go about it with the feeling that you had the right to be free with certain parameters?

Well, we had texts that we made up, most of which I wrote, which were not exactly scores but verbal indications for the kind of thing that we were after-a

12 A selection of MEV performances, accompanied by detailed liner notes and a discography, can be found on Musica Elettronica Viva (2008). Rzewski and MEV's performances and politics are explored by Beal (2009, 2014) and Bernstein (2010). 
kind of improvisation. Stockhausen then did something similar with his group, with Aus den sieben Tagen, ${ }^{13}$ but that was not quite the same thing. And that too was part of the vocabulary of that time. There were several such groups at that time. Ours was one of the first, but there were others as well.

Now I move to questions still about this topic that have been sent to me by other people. Your thoughts on the DIY culture today in terms of technology: machines are more democratically accessible, apps for the iPad. What do you think about that? Will you still engage with technology?

Did you say the "Die" or...?

$D I Y$ - do it yourself.

I see.

I mean in those days, with contact microphones, you had to be able to solder, you had to be able to get the stuff-it wasn't in every supermarket. And now it is, in a way. Although it's not the same, you can't open the iPad just to fool around with it. But would you or do you engage with technology at the present time?

In music, as little as possible.

That seems like a statement: that you'd rather not. Or are there practical reasons?

It did have practical reasons. In the early seventies I moved to New York from Rome, and by that time my children were starting to grow up and more were on the way. And I found that children ... I had to choose between children and electronics. I couldn't afford both. So I opted for my family and I gave all my equipment to Alvin Curran and left for New York with nothing, basically. Like my father left Europe in 1920 with nothing. And I did the same in 1971. So ...

Do you mean...

Unlike my father I did not get rich in America. So I came back to Europe.

[laughs] $\mathrm{OK}$.

But that's one reason I don't use technology. Also ... it's difficult to explain why I... I've become much more interested in the traditional language of writing. I find there is much more to be done in this medium. It seems to me that writing is still at an early stage. It's only been around for about five thousand years, and that is not very long. So I think there is still much more to be done in the area of things like counterpoint. I agree with Elliott Carter. I went to a concert of

13 Stockhausen's Aus den sieben Tagen (composed 1968), fifteen text compositions for intuitive music. 
his music some years ago after which there were questions from the audience. Somebody asked him why he had not done any electronic music-this was some time in the nineties-and he answered that electronics seemed to him to be about sound, whereas he was interested in writing. From the standpoint of writing, far from being in advance, electronics seemed rather a regression to the stage of hieroglyphics. I agree with this. I consider the present obsession with technology to be an obfuscation of the art. It seems to me that music is not technology. Contrary to a widely held view that the future of music is in technology, I take the opposite view.

And yet, one could also say that electronics are even less old than five-thousand-year-old writing. I have a question here about the possible benefits of electronics today, compared with what you experienced in the sixties. What do you think about virtualising performance, like live-stream, interactive, multi-local-would that be artistically interesting? We've heard your answer already, but I have to ask the question: What impact on the autonomy of the arts might this have? You must have opinions about this.

Well. I think there may be some good, positive effects of the present state of communications. It's possible that, because of things like YouTube, it's become easier for performers, young performers, to confront their ideas about performing with documents which are instantaneously available on the internet. Say you're looking for, as I did, some kind of evidence about what the tempo of Schumann's Novelletten No. 2 should be. You can go on the internet and in minutes you can listen to dozens of different interpretations. This undoubtedly is useful, and it may very well be one reason why we have this widely observed phenomenon today of young performers who are demonstrably better than thirty or forty years ago. New music performers, for example, play better today. The new young groups-they play better than new music performers played, say, thirty years ago. And this is especially true in the case of pianists, for some reason. I don't know if that has been explained, but it's generally true.

That might have to do with the next question-we're moving into politics now - and there was a question about how the kind of social artistic experimentation in MEV [Musica Elettronica Viva], as well as the more general experimental circles that you were active in, has had an impact upon arts and society, and how perhaps these experiences should invite and motivate artists today to engage with experimental processes.

There is very little evidence unfortunately to support the view that art has an effect on society. There is evidence in the opposite direction, in great abundance, that society has an influence on art, especially in the case of politicsit's very easy to produce examples of how politics can use and misuse art for its own purposes. There is a great deal of speculation about how art could possibly influence politics, but unfortunately there is very little evidence. One well-known example is that of Hitler, who was very much influenced by art, specifically the art of Richard Wagner. And there is one well-documented episode at the time of the Spanish Civil War-just before the Civil War, or, I guess, 
during it. A bunch of German businessmen were told by Franco that he would offer them certain advantages if they could convince the Führer to enter the war, something which the German high command had absolutely no intention of doing at the time. So these businessmen went to see Hitler, who had just come from a performance of Siegfried in Bayreuth. And he listened to their argument and then said, "Yes, we will do it. We will experiment. We will try our new incendiary weapons. And we will call this Operation Feuerzauber." So here is a concrete example of how art influenced a political decision, or in this case a military one.

But how about the influence of a new artistic process like Musica Elettronica Viva, which wasn't a typical ensemble, back then, but more of a collective. Do you see evidence of how what happened in the sixties resonates today in the way we make music?

To some extent ... MEV had a certain influence on the evolution of pop music. There were a number of groups whom we met in the late sixties and early seventies who had never seen a synthesiser before-MEV was the first group to tour with a simple Moog synthesiser. A number of groups, like Pink Floyd or Kraftwerk, you know who became quite well known later, borrowed considerably from that experience, which is totally normal in music. But whether the music of that period has an active continuing effect now is difficult to say. In some ways it's too early to say, because there is some indication that there are movements now appearing in various parts of the planet which may have some reference to some kind of revival of similar movements of fifty years agothings like the Occupy movements. There is some new thing that is happening, in that the political movements are also having some kind of cultural ... there is a new fusion of politics and culture. But it's too early to say much about it, because it's not clear where that is all going to lead. It's quite encouraging, I think, what we have been able to observe so far in the last six months. ${ }^{14}$ But these things only started less than a year ago. Aside from that I would say, no. No. The musical culture for most people is totally dominated by monopoly capitalism, which leaves no space whatsoever for any kind of experimental or anarchist activity-it's almost invisible. I mean there are certainly things happening in various places which you might call of an underground nature; but basically the experimental avant-garde in the last twenty-five or thirty years has been totally smothered and extinguished by technology and monopoly capitalism. It's quite pitiful. The situation can hardly be worse. It can only get better.

I have two questions left, which are from Darla Crispin. Two years ago Paulo [de Assis] had a project here [at the Orpheus Institute] on Beethoven's Diabelli Variations; 15 we know that you also work with such materials. And the question is, what is the specific attraction of that set of variations? More than just the obvious canonical status of such a work.

14 See the timeline of Occupy Wall Street on Wikipedia (2015).

15 Paulo de Assis's 2010 project on the Diabelli Variations developed later (from 2013) into the much more ambitious project “Deleuzabelli Variations”. See http://musicexperiment21.eu/projects/deleuzabelli-variations/. 
Well, I personally don't find it very attractive.

You don't? Have you played it?

No. I mean I've read through it but I never had the desire to perform it, no.

OK.

I do not consider it a particularly interesting piece, and unfortunately that is true of much of late Beethoven. I think Beethoven got into very deep trouble later in life and turned out a lot of stuff that most people don't want to listen to, for a good reason-because it's not very good. The Große Fuge for example, it's just a bad piece. And the last movement of the Ninth Symphony is a piece of commercial schlock. There are a number of other examples of that. The Diabelli Variations has very good things in it, but I don't see why this piece has this aura around it.

I have one last question, then. It has to do with the reception of difficult music or complex music. And Darla's question is: Do we as artists believe in some kind of discharging of social responsibility through working with both established and new materials? And, in both reproductive and improvisatory means, how can we insure that we're able to communicate these ideas to the least enfranchised people? So the ideas are often complex but the people that listen often have little interface with what we call or might call "high art." To what extent do you regard your own work as intentionally boundary crossing?

Well, there are very few examples in the history of art, I believe, of artistic works that are able to speak to the least enfranchised people. There are a few, but not very many. And, for that matter, it's ... well, I don't know. You can count them on your fingers. Homer, maybe. Tolstoy. Maybe Shakespeare. A few artists like that. Certain painters perhaps, yes. But if you were to take a rigorous view of art, which admitted as valid only those works which spoke to humanity in the broadest sense, you would be left with a very poor selection of art. At the other end of the spectrum there are certainly great works of art that are known only to a small number of people. I guess these late Beethoven string quartets belong to that category-some of them are very good, of course. There's no reason why the two things should be incompatible, any more than one would expect everyone to understand Einstein's theory of relativity. It's not necessary and it's not realistic. It will never happen. There will always be areas of culture which are inaccessible to most people. And there is absolutely nothing wrong with that. 
How did you feel about efforts like [Luigi] Nono's and Pollini's to bring difficult contemporary music, experimental music, to working-class audiences-where they knew that there would have to be some kind of threshold?

He [Nono] didn't really: he did that on a couple of occasions, but he did that because he was in a position to be able to do it, as a member of the Central Committee of the Italian Communist Party. He had a certain influence; he had rich friends. He was able to do that. Not everyone was able to do that. And I doubt very much whether these experiments, which, of course is what they were, really had that much effect. I doubt it. On the other hand it's interesting that he did these things. But one should not spend too much time discussing such things-I think that is not where the issue lies. I can only speak from my own experience. I've tried writings songs. I've tried writing some political songs. I'm not very good at it. My friend Sergio Ortega, who wrote "El pueblo unido," ${ }^{16}$ was very good at it, and [Hans] Eisler was very good at it, and so on. So I don't do that.

What do I do? I'm not very good at writing orchestral music either. I just don't have ... I don't know that much about the orchestra. So what do I do? I try to do the things that I do best: I write piano music. Well, it gets around, to a certain extent, and the results are gratifying. Whether it has an effect on the world is not something I care to spend time worrying about. As far as I can tell there are a few instances where something I've done seems to have changed the ideas of a few individuals here and there-and this is interesting-but I wouldn't expect that the world would be changed because of some fantasy that I indulged in thirty years ago. This will not nor should it happen. In fact, it is not a question that should concern an individual artist, because whether art has an effect on the world is not a question of individuals: it is a question of society and the concatenation of circumstances, which are beyond the control of any individual. There are certainly works of art which have achieved the status of world class objects, of public consciousness, and others which are totally forgotten. There may be very little difference between these two categories in terms of content. But the fact that one thing becomes widely known while the other vanishes is a question of a complex combination of factors that happen to coincide to produce that particular effect.

Well let's spend some time with questions from the audience for you about experimentation and interpretation.

\section{AUDIENCE QUESTIONS}

CATHERINE LAWS: You talked quite a bit earlier about the space for improvisations within performances of your compositions. But I know that in the past you have talked about an ideal of the composition process as improvisation. You talked about experiments with stream-of-consciousness and things like that. I wonder if that's still the case now and how

16 “El pueblo unido jamás será vencido!” (1973) by Sergio Ortega and Quilapayún. See also footnote 3. 
successful you think it is and also how closely it is tied to the fact that you are a performer, whether the process is the same in that sense as soon as you move to writing for other instruments?

Yes, I'm still trying to write down what's in my head, which is I think not as easy to do as you would think. And I don't entirely understand what I'm doing. It seems to be about transferring memory from one short-term memory to a longterm memory. It seems to be about preserving or holding on to some impulse long enough so that it can be expressed in some kind of symbolic language. More than that, I don't know. I don't think anybody does know much about it. It may be that in three or four centuries more will be understood about what goes on in the brain. But I'm not sure if that will be of particular interest to composers. As I said before, I think the important thing in art is not to understand what you're doing but just to do it, And if somebody else can understand it, why it might be useful on some level to somebody but not necessarily to artists. What can I say?

CATHERINE LAWS: Is there a difference then when you... That process: do you find it easier in relationship to piano music because of the direct relationship to the performance, or not necessarily?

Not necessarily. But since I am a pianist, I know the instrument better than I know, say, a trombone. But it doesn't prevent me from writing melodies for a trombone. No, I don't think it has a great deal to do with the instrument.

JOOST VANMAELE: I heard you talk about how you are not really interested in understanding anything about composing. But as you were answering Catherine's question, you were talking about concepts such as short-term memory and long-term memory - about all kinds of concepts that have been generated in order better to understand human ways of thinking. Some would even argue that understanding is an inescapable component in human action. One cannot help using a theory. And you cannot either: you use certain terms that are connected to a certain logic and theory. What would be your position in this?

We understand some things. We don't understand everything. There's a story by Chekov called "In the Ravine" about a young women whose child is burned by boiling water. ${ }^{17}$ She takes the child to the hospital were it dies after a day of agony. On the way back to her village, she's picked up by some peasants who are in an ox cart. She starts to talk to the old man who is driving the ox cart and she asks, "Why do children have to suffer before they die, since they have not sinned?" We can understand why an adult should suffer, because the adult has sinned-but the child has not sinned. The old man is silent for a long time, and then answers, "Who knows. We don't have to understand everything. A bird does not have four wings, but only two wings, because you only need two wings in order to fly." So, in the same way, we don't have to understand everything.

17 See Chekov (2002, 273-76). 
We only need to know what we need to know in order to survive. That's how I feel about writing music: it's a practical question, it's something that has to be done. I don't really know what I am doing, but that doesn't bother me a whole lot. Because, again, on the stage if I am improvising I have no idea what I am doing, and in fact I don't want to know what I'm doing, as that would interfere with my ability to do it. The only thing that counts from the audience's point of view is what comes out. And if I started to think about what I'm doing, I wouldn't be able to do it. I think you have a similar situation in certain sports, where there is an expression, I think it's called being "in the frame." When a pole vaulter is executing this manoeuvre, this complex manoeuvre, you don't think about it, you just do it—because if you start thinking you fall down.

DAVID COLL: Was there ever a point where you really wanted to understand what it was that you were writing?

Well, yes, when I was a student in university. I had some misgivings about becoming an artist, because some voice inside me told me, "No, you don't want to be an artist. You want to be a scientist or somebody who theorises, to better understand what is being done." But then I made an existential decision: rather than try to understand what other people were doing, I made the decision to do it myself. So maybe you can understand it. [laughs]

MICHAEL SCHWAB: It is more a question of understanding than of doing in relation to authority. I thought that at various points you quite clearly described ways of playing in relation to what one might feel has to be done, which leads to the question, how else could it be done? If, as it has been said, good music is open to a wide variety of interpretations, there seems to be a relationship to a fixed norm that good music transgresses. Hence, "understanding" may have less to do with an investigation into existing objects than with an impulse to give relevance by making music in a particular way.

No doubt, yes. I wish I could write an optimistic revolutionary piece of music. I wish I could write something like the Zauberflöte. Well I might have to give that fantasy up for all kinds of reasons. In that case, I'll just do what I can do. I probably will opt for some more limited goal, like trying to write better counterpoint-as good as Schumann, for example. It has to do perhaps with getting older and having less time in front of one to accomplish one's objectives. I don't know. One can become older and wiser but one can also become older and more foolish-even both of these things at the same time. So, yes, I still feel very much like a revolutionary. I consider myself a revolutionary optimist. But at the same time I have to admit that the revolution failed and it was my fault. [laughs] I made some wrong decisions somewhere along the line and I don't want to repeat those mistakes. But I think the grounds for optimism are as strong as the grounds for pessimism. I feel very much on both sides of that question. Never has the world been in such a sorry state as we see it now. At the same time, as Hölderlin says, "Wo aber Gefahr ist, wächst / das Rettende 
auch"- "where there is danger / the saving grows also." ${ }^{18}$ And these are revolutionary words, I think, appropriate to the present time. I would like to jump on that bandwagon, I just don't know how. I'm hoping that Occupy Wall Street will come along and say, "We need a new piece of music from you. Start working." It hasn't happened yet. [audience laughs]

\section{REFERENCES}

Beal, Amy. 2009. “'Music Is a Universal Human Right': Musica Elettronica Viva." In Sound Commitments: Avant-garde Music and the Sixties, edited by Robert Adlington, 99-120. New York: Oxford University Press.

- 2014. "Musica Elettronica Viva and the Art Ensemble of Chicago: Tradition and Improvisation in Self-Exile, ca. 1970." In Crosscurrents: American and European Music in Interaction, 1900-2000, edited by Felix Meyer, Carol J. Oja, Wolfgang Rathert, and Anne C. Shreffler, 364-71. Basel: Paul Sacher Foundation; Rochester, NY: Boydell Press.

Bernstein, David W. 2010. "'Listening to the Sounds of the People': Frederic Rzewski and Musica Elettronica Viva (1966-1972)." In "A Life Drawn to Liberation," special issue on Rzewski, Contemporary Music Review 29 (6): 535-50.

Brooks, William. 2012. "In re: 'Experimental Music.” Contemporary Music Review 31 (1): $37^{-62 .}$

Cage, John. (1940) 1961. "The Future of Music: Credo.” In Cage 1961, 3-6.

-_—. (1955) 1961. "Experimental Music: Doctrine.” In Cage 1961, 13-17. First published 1955 as "Experimental Music" (The Score and I. M. A. Magazine 12: 56-68). . (1957) 1961. "Experimental Music." In Cage 1961, 7-12. -. (1959) 1961. "History of Experimental Music in the United States." In Cage 1961, 67-75. First published 1959 as "Zur Geschichte der experimentellen Musik in den Vereinigten Staaten," translated by Heinz-Klaus Metzger (Darmstädter Beiträge zur Neuen Musik 2: 46-53).

. 1961. Silence: Lectures and Writings. Middletown, CT: Wesleyan University Press.
Chekov, Anton. 2002. "In the Ravine.” In The Lady with the Little Dog and Other Stories, 1896-1904, translated by Ronald Wilks, 241-83. London: Penguin. Chekov's story written $1899^{-1900 .}$

Hölderlin, Friedrich. [1803] 1998. "Patmos." In Selected Poems and Fragments, translated by Michael Hamburger, edited by Jeremy Adler, 231-43. London: Penguin. "Patmos" written 1803 . This edition first published 1994 (London: Anvil Press Poetry).

Musica Elettronica Viva. 2008. MEV 40 (1967-2007). New World Records, 806752, 4 compact discs.

Nicholls, David. 1990. American Experimental Music, 1890-1940. Cambridge: Cambridge University Press.

Nyman, Michael. 1999. Experimental Music: Cage and Beyond. 2nd ed. Cambridge: Cambridge University Press. First ed. published 1974 (London: Studio Vista). Rubinstein, Arthur. 1973. My Young Years. London: Jonathan Cape.

Suits, Bernard. 2005. The Grasshopper: Games, Life and Utopia. 2nd ed. Peterborough, ON: Broadview Press. First ed. published 1978 (Toronto: University of Toronto Press).

Thomson, Virgil, and Peter Dickinson. (1987) 2006. "Virgil Thomson: Interview with Peter Dickinson, Chelsea Hotel, New York City, July 1, 1987." In CageTalk: Dialogues with and about John Cage, edited by Peter Dickinson, 111-21. Rochester, NY: University of Rochester Press.

Tytell, John. 1995. The Living Theatre: Art, Exile, and Outrage. New York: Grove Press.

Wikipedia. 2015. "Timeline of Occupy Wall Street.” Accessed 31 August 2015. https:// en.wikipedia.org/wiki/Timeline_of_ Occupy_Wall_Street. 

ONLINE MATERIALS

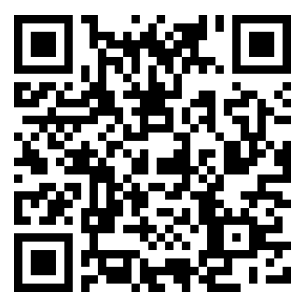

As further illustrations to chapters three, four, five, seven, and eleven in this publication, an online repository of audio and video examples has been created and hosted within the website of the Orpheus Institute, Ghent. These examples, which should be viewed in connection with a reading of the relevant passages, may be accessed under the URL: http://www.orpheusinstituut.be/en/ experimental-affinities-in-music-repository. 

Paulo de Assis is the Principal Investigator of the European Research Councilfunded project "Experimentation versus Interpretation: Exploring New Paths in Music Performance in the Twenty-First Century" [Music Experiment 21], hosted at the Orpheus Institute in Ghent (Belgium). He is a trained concert pianist, musicologist, and editor with particular interests in contemporary composition and late twentieth-century French philosophies. His current research challenges orthodox definitions of musical works and their renderings. He has authored two books (on the music of Luigi Nono and Camillo Togni) and edited seven others (on music notation and on contemporary composers). He is a Research Fellow at the Orpheus Institute and the chair of the international conference series Deleuze and Artistic Research (DARE).

Thomas Christensen is the Avalon Professor of Music and the Humanities at the University of Chicago, where he also serves as Associate Dean of the College and Master of the Humanities Collegiate Division. Thomas Christensen's scholarly research centers on the history of music theory, and he is the editor of the Cambridge History of Western Music Theory (published in 2003). Fundamental to his work has been a desire to situate the many intellectual frames, arguments, and linguistic models used by writers in the early modern period deeply within cultural discourses. His work has received support and recognition over the years from a variety of academic associations and funding agencies. In 2011-12 he was a fellow at the Wissenschaftskolleg in Berlin. He has also enjoyed a long and fruitful collaboration with the Orpheus Institute in Ghent, co-chairing Workshops in 2002 and 2006.

Hermann Danuser has taught since 1993 at the Humboldt University in Berlin, as Professor for Historical Musicology. In addition, he coordinates the research of the Paul Sacher Foundation in Basel and is a member of the Berlin-Brandenburg Akademie der Wissenschaften. He has been guest professor at several universities in Europe, in the United States, and in China. In 2005 Royal Holloway, University of London, bestowed upon him an honorary doctorate. His research interests include music history and historiography since the eighteenth century, aesthetics, music theory, analysis, and interpretative practices.

Felix Diergarten obtained diplomas in conducting and music theory in Dresden, where he studied with Ludwig Holtmeier and Clemens Kühn and went on to study "Theorie der Alten Musik" at the Schola Cantorum Basiliensis with Markus Jans. He was active as repetiteur, assistant conductor, and conductor at various theatres, including the Nederlandse Opera Amsterdam and the Sächsische Staatsoper Dresden. He obtained a Dr.phil. in music theory with a dissertation on Joseph Haydn's symphonies. Since 2009 he has been teaching "Historische Satzlehre" and "Theorie der Alten Musik" (music theory, history of theory, and analysis) at the Schola Cantorum Basiliensis. 
Leon Fleisher Renowned pianist and conductor Leon Fleisher became a student of Artur Schnabel at the age of nine and made his debut with the New York Philharmonic under Pierre Monteux at the age of sixteen. He quickly established himself as one of the world's premier classical pianists, concertising with every major orchestra and making numerous touchstone recordings. At age thirty-seven, at the height of his career, he was suddenly struck silent with a neurological affliction known as focal dystonia, rendering two fingers on his right hand immobile. In the nearly forty years after his keyboard career was so suddenly curtailed, he followed two parallel careersas conductor and teacher-while learning the extraordinary but limited repertoire for piano left-hand. He began conducting in 1967, but never gave up the idea of playing with both hands again. Experimental treatments using a regimen of rolfing and botulinum toxin (Botox) injections finally restored the mobility in Fleisher's hand, and for several years he has played with both hands, winning enormous acclaim for his 2004 "two-hand" recording aptly titled Two Hands. Fleisher's story is the subject of the 2006 Oscar- and Emmy-nominated documentary film of the same name, written and directed by Nathaniel Kahn. The first American to win the prestigious Queen Elisabeth Competition (Belgium, in 1952), Fleisher now holds numerous honours including the Johns Hopkins University President's Medal and honorary doctorates from the San Francisco Conservatory of Music, Amherst College, Boston Conservatory, Cleveland Institute of Music, Juilliard School of Music, and Peabody Institute. In 2005, Fleisher was honored by the French government and was named Commander in the French Order of Arts and Letters, the highest rank of its kind. Fleisher received Kennedy Center Honors in 2007, at its thirtieth annual celebration of the arts. Holder of the Andrew W. Mellon Chair at the Peabody Conservatory of Music since 1959, Mr. Fleisher also serves on the faculties of the Curtis Institute of Music in Philadelphia and the Royal Conservatory of Music in Toronto, as well as the Steans Institute of the Ravinia Festival.

Lydia Goehr is Professor of Philosophy at Columbia University. In 2009-10 she received a Lenfest Distinguished Columbia Faculty Award, in 2007o8 the Graduate Student Advisory Council (GSAC)'s Faculty Mentoring Award (FMA), and in 2005 a Columbia University Presidential Award for Outstanding Teaching. She is a recipient of Mellon, Getty, and Guggenheim Fellowships, and in 1997 she was the Visiting Ernest Bloch Professor in the Music Department at the University of California, Berkeley, where she gave a series of lectures on Richard Wagner. She has been a Trustee of the American Society for Aesthetics and is a member of the New York Institute of the Humanities. In 2012, she was awarded the H. Colin Slim Award by the American Musicological Society for an article on Wagner's Die Meistersinger. Lydia Goehr is the author of The Imaginary Museum of Musical Works: An Essay in the Philosophy of Music (1992; second edition with a new essay, 2007); The Quest for Voice: Music, Politics, and the Limits of Philosophy. Essays on Richard Wagner (1998); Elective Affinities: Musical Essays on the History of Aesthetic Theory 


\section{Notes on Contributors}

(2008), and co-editor with Daniel Herwitz of The Don Giovanni Moment: Essays on the Legacy of an Opera (2006). She has written many articles on the work of Theodor W. Adorno, Maurice Merleau-Ponty, and Arthur Danto. She offers courses in the history of aesthetic theory, the contemporary philosophy of the arts, critical theory, and the philosophy of history. Her research interests are in German aesthetic theory and in particular in the relationship between philosophy, politics, history, and music.

Martin Kirnbauer was trained as an instrument maker and worked as a conservator for historical musical instruments at the Germanisches Nationalmuseum in Nuremberg. After studying musicology at the universities in Erlangen and Basel, he obtained his $\mathrm{PhD}$ with a work on a late-medieval songbook in 1998, followed by a second thesis ("Habilitation") in 2007 on microtonal music in the seventeenth century. Since 2004 he has been Director of the Museum for Music in Basel and curator of the collection of musical instruments of the Historical Museum, as well as Privatdozent for musicology at the University of Basel. He has authored numerous publications concerned with early music, performance practice, organology, and musical iconography.

Lawrence Kramer is Distinguished Professor of English and Music at Fordham University, the editor of the journal 19th Century Music, and a composer whose works have been performed internationally. He has held nine visiting professorships at universities in the United States, Canada, Europe, and China; his work has been the subject of several symposia and of session meetings at scholarly societies, again both in the US and abroad, and his writings have been translated into seven languages. His numerous books on music and culture include, most recently, Why Classical Music Still Matters (California, 2007), Interpreting Music (California, 2010), and Expression and Truth: On the Music of Knowledge (California, 2012). Musical Meaning and Human Values (Fordham, 2009), co-edited with Keith Chapin, is a collection based on an international conference held in Kramer's honour in 2007. The conference featured the premiere of nine songs from his cycle The Wanderer and His Shadow to texts adapted from Nietzsche's The Gay Science. Recent performances include A Ring of Light (song cycle; Edinburgh, 2007), Song Acts (Vienna, 2009), That Lonesome Whistle (song cycle; New York, 2010 and 2011 and Newton, Massachusetts, 2013), "The Wild Swans" (solo piano; New York, 2011), Crossing the Water (cantata; campus of the Santa Fe Opera, 2011), Another Time (song cycle for voice, violin, and cello; New York, 2012), and "Intermezzo" (solo cello; Old Westbury, Long Island, Wellfleet, Massachusetts, and New York, 2012).

Helmut Lachenmann (born 27 November 1935, in Stuttgart) studied piano, theory, and counterpoint at the Musikhochschule Stuttgart from 1955 to 1958; from $195^{8}$ to 1960 he studied composition with Luigi Nono in Venice. The first public performances of his works took place at the 
Venice Biennale in 1962 and at the International Summer Courses for New Music in Darmstadt. After teaching at the university in Ludwigsburg, Lachenmann became Professor for Composition at the music conservatories in Hannover (1976-81) and in Stuttgart (1981-99). He gave many seminars, workshops, and master classes in Germany and abroad, including several occasions at the Summer Courses in Darmstadt between 1978 and 2006. In 2008 Lachenmann was Fromm Foundation Visiting Professor at the Department of Music of Harvard University. In 2010 he became a Fellow of the Royal College of Music in London. Helmut Lachenmann has received numerous awards for his compositional work, among them the Ernst von Siemens Musikpreis in 1997, the Royal Philharmonic Society Award (London) in 2004, and in 2008 the Berliner Kunstpreis as well as the Leone d'Oro of the Venice Biennale. Lachenmann is an honorary doctor at the Musikhochschule Hannover and a member of the Academies of Arts in Berlin, Brussels, Hamburg, Leipzig, Mannheim, and Munich.

Mark Lindley (born 1937) is a noted musicologist and, more recently, a historian of modern India and a teacher of economics. Born in Washington, D.C., he studied at Harvard University (AB), Juilliard School of Music (MS), and Columbia University (DPhil). He has taught at various universities, including Columbia University, City University of New York, Washington University, University of London, Oxford University, University of Regensburg, Chinese University of Hong Kong, University of Kerala, Istanbul Technical University, Yildiz Technical University, Bogaziçi University, and Samskar Ashram Vidyalayam. He has lectured on economics at Gujarat Vidyapith and at the Gokhale Institute of Politics and Economics. He is a University Chair professor in the School of Economics at the University of Hyderabad.

Frederic Rzewski Born in Westfield, Massachusetts, in 1938, Frederic Rzewski studied music with Charles Mackey of Springfield, and subsequently with Walter Piston, Roger Sessions, and Milton Babbitt at Harvard and Princeton universities. He went to Italy in 1960, where he studied with Luigi Dallapiccola and met Severino Gazzelloni, thus beginning a career as a performer of new piano music. Rzewski's early friendship with Christian Wolff and David Behrman, and (through Wolff) his acquaintance with John Cage and David Tudor strongly influenced his development in both composition and performance. In Rome, in the mid-sixties, together with Alvin Curran and Richard Teitelbaum, he formed the MEV (Musica Elettronica Viva) group, which quickly became known for its pioneering work in live electronics and improvisation. From 1983 to 2003 Rzewski was Professor of Composition at the Conservatoire Royal de Musique in Liège, Belgium. He has also taught at the Yale School of Music, the University of Cincinnati, the State University of New York at Buffalo, the California Institute of the Arts, the University of California at San Diego, Mills College, the Royal Conservatory of the Hague, the Hochschule der Künste in Berlin, and the Hochschule für Musik in Karlsruhe. 
Luk Vaes studied piano with Claude Coppens (Belgium), Aloys Kontarsky (Germany), and Yvar Mikhashoff (US), among others, won first prizes in several international competitions and concertised with musicians such as Uri Caine and Thomas Quasthoff at the most renowned festivals in the EU and US. His recordings of piano works of Mauricio Kagel (Winter \& Winter) won nine international prizes. In 2009 he obtained his doctorate at Leiden University (through the docARTES programme). His dissertation on the theory, history, and performance practice of extended piano techniques has since enjoyed widespread usage by practitioners. Currently he is Fellow in Artistic Research at the Orpheus Research Centre in Music research group and coordinator of the doctoral programme for artists (docARTES) at the Orpheus Institute and the Royal Conservatoire in The Hague.

Edward Wickham is Fellow and Director of Music at St Catharine's College, Cambridge. He combines his duties in Cambridge with performing engagements throughout the world, principally with the Clerks, the vocal ensemble that he formed in 1992. Dr Wickham read modern history at Christ Church, Oxford, where he was also a choral scholar. His performing interests then led him to read for an MA in medieval studies at King's College, London, and finally a $\mathrm{PhD}$ in music under the supervision of Reinhard Strohm. As an affiliate lecturer at the Faculty of Music in Cambridge he lectures and supervises on fifteenth- and sixteenth-century music, the history of musical notation; he also serves as Course Director of the MMus in Choral Studies. In 2008 Dr Wickham established the St Catharine's Girls' Choir to complement the existing mixed student choir; this remains the only college-based choir for girls in the country. More recently he set up the Cambridge Singing School, which caters for boys and girls and offers tuition in vocal technique and music history, as well as in classical choral repertoire.

With the Clerks, Dr Wickham has made a series of ground-breaking recordings, principally of Franco-Flemish Renaissance music. In 2001 the ensemble completed an award-winning survey of the music of Jean Ockeghem; more recent projects have included first-time recordings of polyphony by composers such as Josquin, Barbireau, and Regis. With the Clerks, Edward Wickham has pioneered the practice of singing from manuscript notation, a process that has informed many of the group's recordings and live performances. In recent years Dr Wickham has been exploring, through collaborative and experimental projects, modes of performance which break out of the traditional Western classical tradition. With multi-media sound installations, partnerships with singers from the Middle East, and ground-breaking educational and outreach programmes, he is committed to pursuing an idiosyncratic agenda of artistic innovation and social participation. His latest project, Tales from Babel, is funded by an Arts Award from the Wellcome Trust and entails an investigation of the phenomenon of "auditory streaming" in complex, polytextual music. 

A

Adlung, Jakob 204

Adorno, Theodor W. 10, 15, 16, 17, 18, 19, 23, 24, 25, 26, $28,29,31,32,33,34,35,36,37,38,42,47,58,100$, $163,187,188,189$ Minima Moralia 15

Agostini, Lodovico 74

Andrieu, François 129

Antoinette, Marie 158

Aquinas, Thomas 47,52

Aristotle $42,43,44,46,48,49,50,51,52,58,59,60$, $189,190,205$

\section{B}

Babbitt, Milton 24

Bach, Johann Sebastian 11, 105, 106, 107, 109, 110, 111, $112,113,114,118,119,12 \mathrm{O}, 121,122,123,124,2 \mathrm{O}$, 205

Bacon, Francis 10, 15, 16, 17, 18, 19, 21, 23, 24, 26, 27, $28,29,30,31,36,38,42,43,47$ De Sapientia Veterum 27 Novum organum 27,47

Bacon, Roger 10, 43, 47

Barber, Samuel 142

Bauer, Bruno 20

Becker, Howard S. 9

Beethoven, Ludwig van $11,13,95,96,103,111,117,157$, $158,161,162,163,165,169,170,172,173,188,191$, $214,215,216,217,219,221,225,230,23$

Benjamin, Walter 21, 192

Bentham, Jeremy 20

Berg, Alban 100, 102

Berio, Luciano 93, 94

Berlioz, Hector 96

Biel, Michael von 11, 95

Boethius, Anicius Manlius S. 12, 43, 49, 199, 200, 201, 202, 203, 208, 210

Borio, Gianmario 178

Boulez, Pierre 32, 94, 99

Brahms, Johannes 177, 186, 189, 191

Braxton, Anthony 220

Bruckner, Anton 96, 98, 102

Brungart, Douglas 131, 136

Büchner, Georg 98, 102

Buono, Gianpietro del 10, 79

Butler, Judith 11, 153

C

Cafiero, Rosa 208

Cage, John 8, 10, 11, 15, 16, 17, 18, 19, 24, 25, 26, 27, 28, $30,31,32,33,35,36,37,38,42,95,102,103,104$ $178,213,214,215,220,223,224,225,226,227,235$ Caimo, Gioseppe 74

Carrillo, Julián 64

Carter, Elliot 24, 228

Cassirer, Ernst 18, 27, 28, 30

Cherry, Colin 131

Chopin, Fryderik 95, 105, 106, 169, 173, 223

Cohen, Peter 23

Colonna, Fabio 10, 74, 75, 78

Cone, Edward T. 187,192
$\mathrm{D}$

Dahlhaus, Carl 184, 185, 188

D'Alembert, Jean Le Rond 155, 156, 166

Deleuze, Gilles 7,163, 164

Derrida, Jacques 164

Dewey, John 20, 34

Diderot, Denis 155, 156, 157, 159, 162, 166

Diruta, Girolamo 67

Doni, Giovanni Battista 10, $83,84,85,87$

Dorian, Frederick 85, 105, 108, 112, 191

Dunsby, Jonathan 191

\section{$\mathrm{E}$}

Eggebrecht, Hans Heinrich 184, 185

Engels, Friedrich 20

Ensslin, Gudrun 96

F

Feldman, Morton 11, 97, 223

Ferneyhough, Brian 99

Fétis, François-Joseph 12, 210

Fiesco, Giulio 74

Finscher, Ludwig 185

Foucault, Michel 7, 152, 153, 163, 164

Fox, Christopher 11, 130, 131, 136, 137, 144

Freud, Sigmund 11, 102, 153, 157, 163

Froberger, Johann Jacob 10, 86, 87

Frye, Walter 11, 142, 143

Fulda, Adam von 187

\section{G}

Gentili, Carlo 178

Gesualdo, Carlo 75, 85

Gilmore, Bob 8, 9

Gjerdingen, Robert 208

Goethe, Johann W. 11, 18, 22, 23, 24, 154, 189

Gould, Glenn 188

Guattari, Félix 7

Guido of Arezzo 12, 210

Gushee, Lawrence 43

\section{$\mathrm{H}$}

Hába, Alois 64

Hacking, Ian 7

Hawkins, Sarah 132, 137, 138, 141, 144

Haydn, Joseph 11, 13, 148, 154, 157, 158, 159, 16o, 161, $162,163,165$

Hegel, Georg Wilhelm F. 11, 151, 152, 164, 189

Heidegger, Martin 18

Heinichen, Johann 209, 210

Heinrich, Antje 108, 132, 137, 144, 181, 185

Helms, Hans G. 34

Herder, Johann Gottfried 11, 159, 160, 162

Hölderlin, Friedrich 100, 234, 235

Hollandrinus, Johannes 12, 206, 207, 208

Holtmeier, Ludwig 44, 57, 210

Hooke, Robert 23

Horkheimer, Max 16, 17, 18, 23, 28, 32

Huber, Klaus 64, 65, 89

Hume, David 155, 162

Huron, David 138, 139, 140, 141 
I

Isidore of Seville 48 Ives, Charles 64

J

Johnson, Tom 219

\section{$\mathrm{K}$}

Kagel, Mauricio 11, 95, 96, 99 Tactil 11, 95, 99, 101 Unter Strom 11, 99

Kant, Immanuel 32, 189

Keller, Johannes 10, 64, 184

Kempff, Wilhelm 214

Kilwardby, Robert 48

Kirnberger, Johann Philipp 12, 120, 210

Knight, Sarah 132, 137, 144

Koch, Heinrich Christoph 181, 182

Kraft, Leo 106

Kronos Quartet 192, 193

Kuhn, Thomas 207

$\mathrm{L}$

Lacan, Jacques 11, 153, 164

Lang-Alsvik, Gunhild 10, 64

Lasso, Orlando di 71

Ledbetter, David 11, 105

Leibniz, Gottfried W. 19, 23

Leodiensis, Jacobus 45, 53, 55

Lombardus, Petrus 44

Luhmann, Niklas 152

Lyotard, Jean-François 7

\section{M}

Machaut, Guillaume de 129

Mach, Ernst 20

Mahler, Gustav 103, 170, 186

Marcuse, Herbert 18, 96

Marenzio, Luca 75

Marx, Karl 20, 102

Mayer Brown, Howard 191

Mayone, Ascanio 10, 74, 75

Mazzocchi, Domenico 10, 74, 78, 86, 87

Mendelssohn, Felix 213, 218, 220

Metzger, Heinz-Klaus 32, 34, 215

Michels, Ulrich 43, 44, 56, 62

Mill, John Stuart 20

Moerbeke, Willem van 45,48

Mozart, Wolfgang Amadeus 100, 101, 109, 117, 168, 173,216

Muffat, Georg 10, 87

Muris, Johannes de 10, 12, 43, 44, 45, 46, 48, 49, 50, $51,52,53,54,55,56,58,59,60,61,207,210$

\section{$\mathrm{N}$}

Neidhardt, Johann Georg 204

Niedt, Friedrich Erhard 204, 205

Nietzsche, Friedrich 13,153

Nono, Luigi 11, 91, 92, 93, 94, 102, 103, 104, 232

Cori di Didone 94

$\mid$ Ha venido $\mid$ Canciones para Silvia 94

Nyman, Michael 8, 32, 223
$\mathrm{O}$

Ockeghem, Johannes 11

P

Palm, Siegfried 96

Pesic, Peter 19, 27, 28, 29, 30, 40

Plato 28, 52, 164, 189

Republic 28

Polanyi, Michael 152

Popper, Karl 18, 35

Pousseur, Henri 11, 94, 95, 97

Pythagoras 48

Q

Quintilian $5^{6}$

$\mathrm{R}$

Rameau, Jean-Philippe 12, 197, 198, 199, 203, 204, 205, 206, 210

Ravel, Maurice 103, 110

Reich, Steve 147

Réôme, Aurelian of 200

Ricœur, Paul 7

Riemann, Hugo 12, 183, 184, 186, 210

Rink, John 192

Rore, Cipriano de 75

Rossi, Michelangelo 86

Russolo, Luigi 20

\section{S}

Sabbatini, Galeazzo 10, 82, 87

Saint Victor, Hugo of 42, 47

Saladin, Eva 10, 64

Sanguinetti, Giorgio 208

Schaeffer, Pierre 34, 96

Schenker, Heinrich 12, 108, 109, 110, 197, 198, 205, 210

Schiller, Friedrich 18, 23, 24

Schilling, Gustav 182, 183

Schnabel, Arthur 12, 168, 169, 170, 171, 175

Schnebel, Dieter 178

Schoenberg, Arnold 32, 33, 98, 100, 102, 113, 147

Schröter, Christoph Gottlieb 204

Schubert, Franz 11, 153, 163,169

Schulz, Johann Abraham P. 180

Schumann, Robert 213, 215, 216, 217, 218, 221, 222, 229, 234

Schwarte, Ludger 7,15

Shaw, George Bernard 189

Stein, Gertrude 27

Stevens, Wallace 163

Stockhausen, Karlheinz 93, 94, 102, 184, 222, 226, 228

Plus-Minus 94

Strauss, Richard 96,110

Suits, Bernard 213, 215

Sulzer, J.G. $179,180,181,198$

$\mathrm{T}$

Takahashi, Yuji 213, 214, 218

Tallis, Thomas 147

Tenney, James 8 
Index

Thomson, Virgil 226

Treiber, Johann Philipp 204

Tudino, Cesare 74

U

Ullmann, Viktor 28

V

Vaucanson, Jacques $157,15^{8}$

Vicentino, Nicola 10, 69, 70, 71, 73, 74, 83

Vitry, Philippe de 44

Voltaire (François-Marie Arouet) 11, 17, $15^{8}$
W

Wagner, Richard 102, 177, 229

Walther, Johann Gottfried 180

Weill, Kurt 21

Werckmeister, Andrea 107

Wind, Edgar 22, 34

Wolf, Daniel 8, 9

Wolff, Christoph 106, 120, 186, 214, 218, 223

Z

Zarlino, Gioseffo 12, 69, 108, 210

Zayaruznaya, Anna 130, 131

Zimmermann, Bernd Alois 96

Žižek, Slavoj 11, 153 

Editor

Paulo de Assis

Authors

Paulo de Assis

Thomas Christensen

Hermann Danuser

Felix Diergarten

Lydia Goehr

Martin Kirnbauer

Lawrence Kramer

Mark Lindley

Luk Vaes

Edward Wickham

Interviewees

Leon Fleisher

Helmut Lachenmann

Frederic Rzewski

Copy-editor

Edward Crooks

Series editor

William Brooks

Lay-out

Studio Luc Derycke

Typesetting

Friedemann bvba

Cover image

Lucia D’Errico
This project has received funding from the European Union's Seventh Framework Programme for research, technological development and demonstration under ERC grant agreement $n^{\circ} 313419$
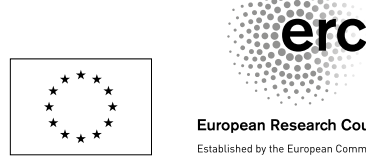

European Research Council

(C) 2015 by Paulo de Assis and

Leuven University Press /

Universitaire Pers Leuven /

Presses Universitaires de Louvain.

Minderbroedersstraat 4

B-30oo Leuven (Belgium)

ISBN 9789462700611

eISBN 9789461661883

$\mathrm{D} / 2015 / 1869 / 59$

NUR: 663

\section{GPRC \\ Guaranteed
Peer Reviewed
Colent \\ Content}

This work is licensed under a Creative Commons Attribution-NonCommercial-NoDerivatives 4.o International License (CC-BY-NC-ND). For more information, please visit creativecommons.org.

\section{(ब) $(\Theta \Theta \Theta$}

This book is published in the Orpheus Institute Series.

http://dx.doi.org/10.11116/9789461661883 

The Orpheus Institute has been providing postgraduate education for musicians since 1996 and introduced the first doctoral programme for music practitioners in Flanders (2004). Acting as an umbrella institution for Flanders, it is co-governed by the music and dramatic arts departments of all four Flemish colleges, which are strongly involved in its operation.

Throughout the Institute's various activities (seminars, conferences, workshops, and associated events) there is a clear focus on the development of a new research discipline in the arts, one that addresses questions and topics that are at the heart of musical practice, building on the unique expertise and perspectives of musicians and maintaining a constant dialogue with more established research disciplines.

Within this context, the Orpheus Institute launched an international Research Centre in 2007 that acts as a stable constituent within an ever-growing field of enquiry. The Orpheus Research Centre is a place where musical artists can fruitfully conduct individual and collaborative research on issues that are of concern to all involved in artistic practice. Its core mission is the development of a discipline-specific discourse in the field of artistic research in music. 
The Orpheus Institute Series encompasses monographs by fellows and associates of the Orpheus Institute, compilations of lectures and texts from seminars and study days, and edited volumes on topics arising from work at the institute. Research can be presented in digital media as well as printed texts. As a whole, the series is meant to enhance and advance discourse in the field of artistic research in music and to generate future work in this emerging and vital area of study.

OTHER TITLES IN THIS SERIES:

- Artistic Experimentation in Music: An Anthology Darla Crispin and Bob Gilmore (eds.)

2014, ISBN 9789462700130

- Multiple Paths (CD): Bach / Parra / Tenney Juan Parra Cancino, with Ensemble Modelo62

2014

- Composing under the Skin: The Music-making Body at the Composer's Desk Paul Craenen

2013, ISBN 9789058679741

- Sound \& Score: Essays on Sound, Score and Notation Paulo de Assis, William Brooks, Kathleen Coessens (eds.) 2013, ISBN 9789058679765

- Experimental Systems: Future Knowledge in Artistic Research Michael Schwab (ed.)

2013, ISBN 9789058679734

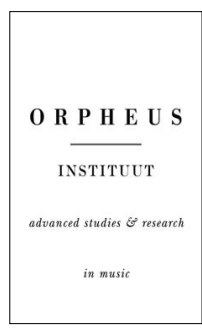

Orpheus Institute

Korte Meer 12

B - 9000 Ghent

Belgium

tel: +32 (o) 93304081

fax: +32 (o) 93304082

e-mail: info@orpheusinstituut.be

website: www.orpheusinstituut.be 